\title{
Evaluation of Quality Assurance/Quality Control Data Collected by the U.S. Geological Survey for Water-Quality Activities at the Idaho National Engineering Laboratory, Idaho, 1989 through 1993
}

\section{U.S. GEOLOGICAL SURVEY}

Water-Resources Investigations Report 96-4148
RECEIVED

JUN 091997

\section{OSTI}

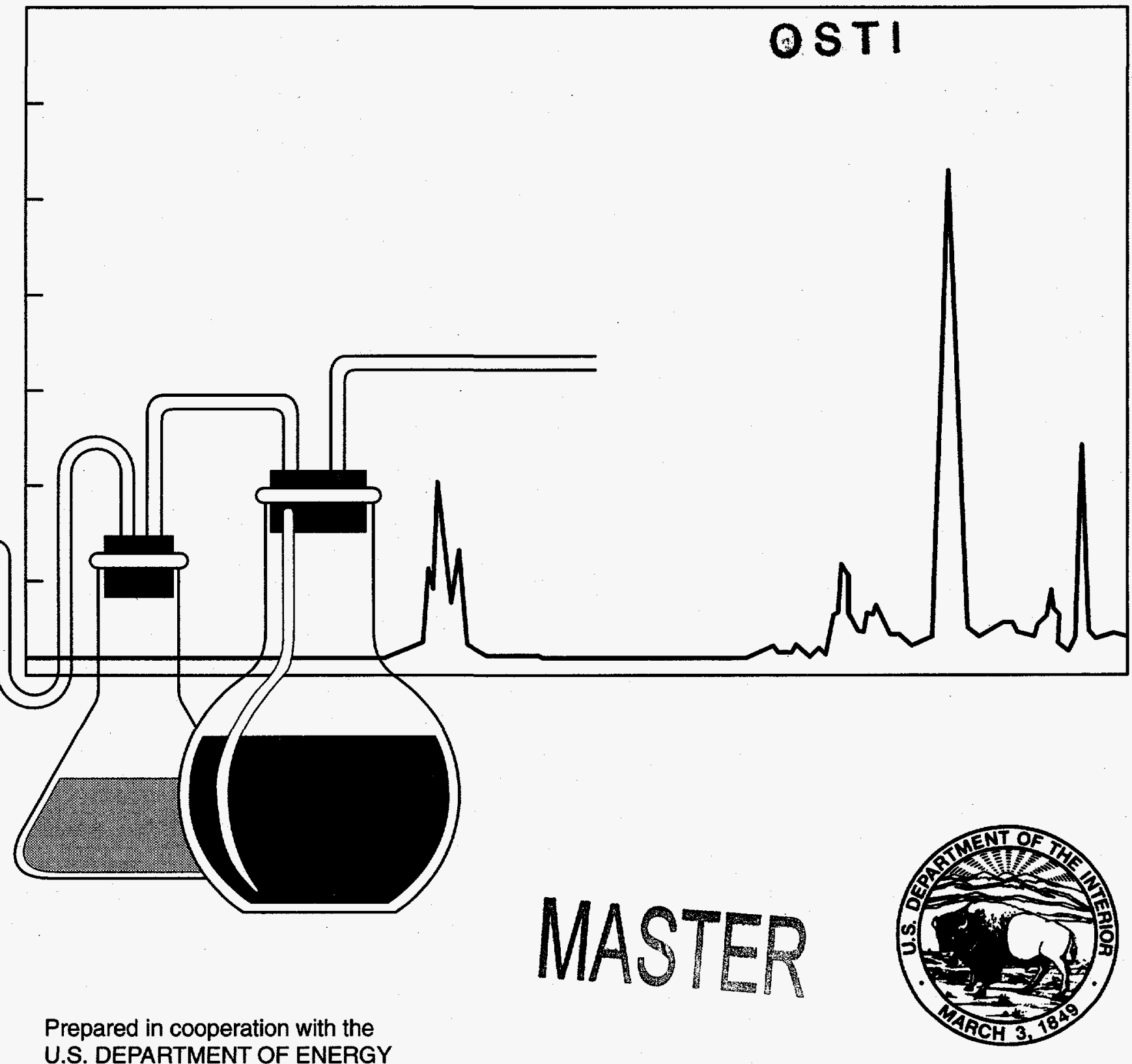





\title{
Evaluation of Quality Assurance/Quality Control Data Collected by the U.S. Geological Survey for Water-Quality Activities at the Idaho National Engineering Laboratory, Idaho, 1989 through 1993
}

by LINDA M. WILLIAMS

\section{DISCLAIMER}

\begin{abstract}
This report was prepared as an account of work sponsored by an agency of the United States Government. Neither the United States Government nor any agency thereof, nor any of their employees, makes any warranty, express or implied, or assumes any legal liability or responsibility for the accuracy, completeness, or usefulness of any information, apparatus, product, or process disclosed, or represents that its use would not infringe privately owned rights. Reference herein to any specific commercial product, process, or service by trade name, trademark, manufacturer, or otherwise does not necessarily constitute or imply its endorsement, recommendation, or favoring by the United States Government or any agency thereof. The views and opinions of authors expressed herein do not necessarily state or reflect those of the United States Government or any agency thereof.
\end{abstract}

\section{U.S. GEOLOGICAL SURVEY}

Water-Resources Investigations Report 96-4148

Prepared in cooperation with the U.S. DEPARTMENT OF ENERGY

Idaho Falls, Idaho

June 1996

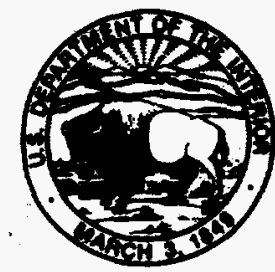




\title{
DEPARTMENT OF THE INTERIOR \\ BRUCE BABBITT, Secretary
}

\author{
U.S. GEOLOGICAL SURVEY \\ GORDON P. EATON, Director
}

Any use of trade, product, or firm names is for descriptive purposes

only and does not imply endorsement by the U.S. Government

For additional information write to

U.S. Geological Survey

INEL, MS 4148

P.O. Box 2230

Idaho Falls, ID 83403-2230
Copies of this report can be purchased from:

U.S. Geological Survey

Branch of Information Services

Box 25286

Denver, CO 80225-0286 


\section{DISCLAMIER}

Portions of this doenment may be illegible in electronic image products. Images are produced from the best available original document. 



\section{CONTENTS}

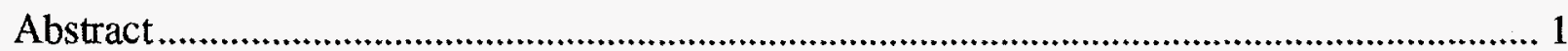

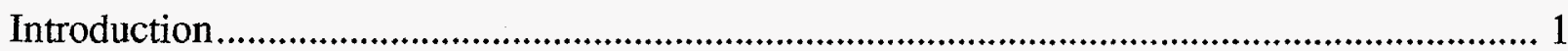

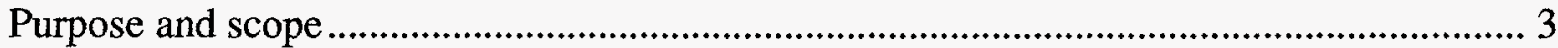

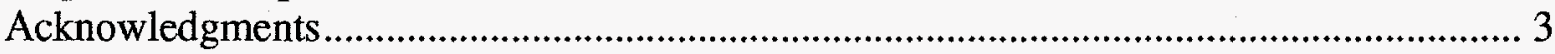

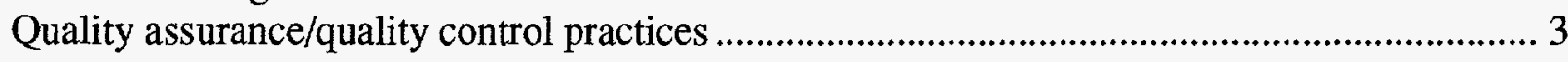

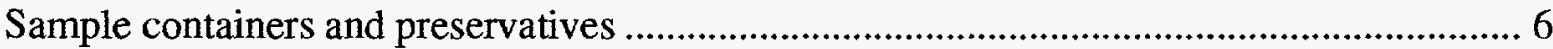

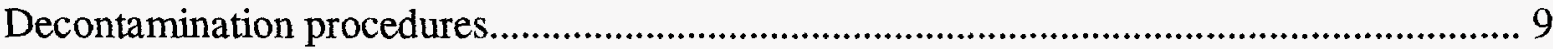

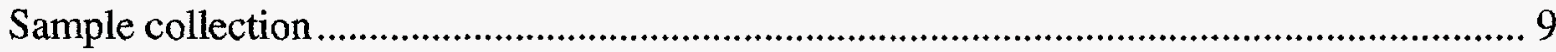

Analytical methods and reporting of data ............................................................................ 11

Quality assurance/quality control samples, replicate pairs of samples....................................... 11

Statistical comparisons of replicate pairs of samples.......................................................... 11

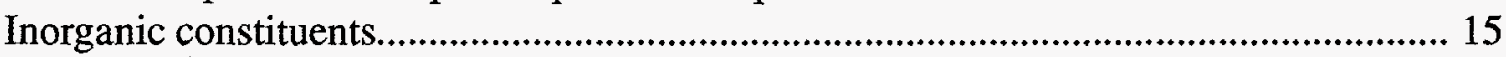

Gross radioactivity and radionuclides ........................................................................... 16

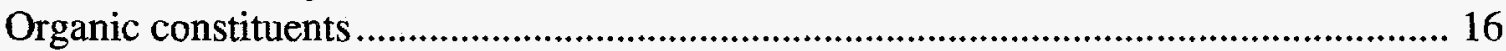

Summary of statistical comparisons of replicate pairs of samples ....................................... 17

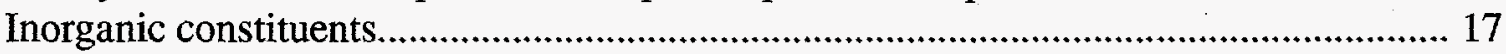

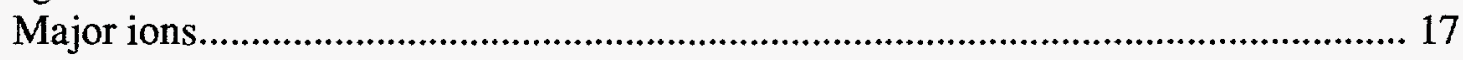

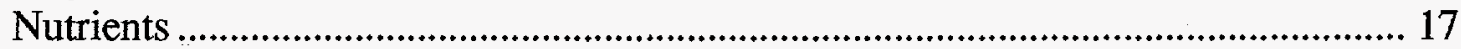

Trace elements .................................................................................................. 17

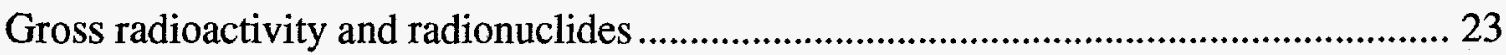

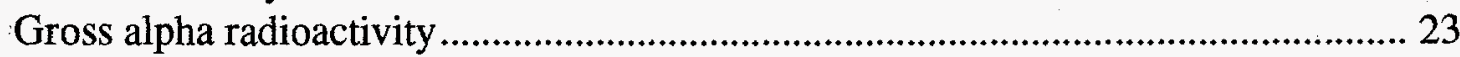

Gross beta radioactivity .......................................................................................... 24

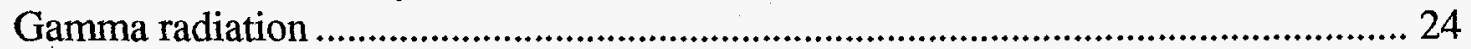

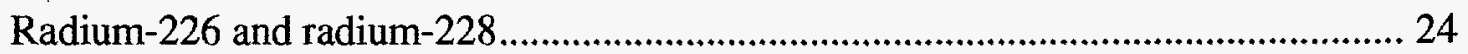

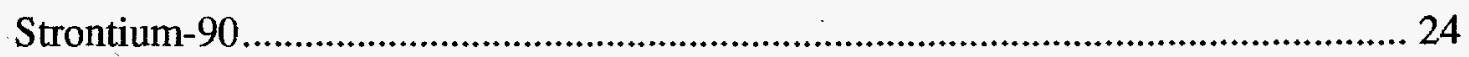

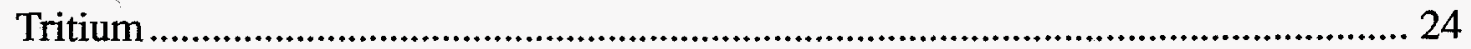

Transuranics: americium-241, plutonium-228, and plutonium-239/240...................... 24

Organic constituents............................................................................................... 24

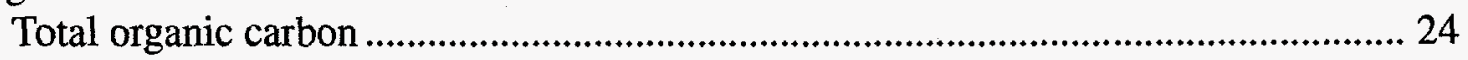

Volatile organic compounds ....................................................................................... 25

Semivolatile organic compounds, pesticides, gross polychlorinated compounds, and Aroclors................................................................................... 25

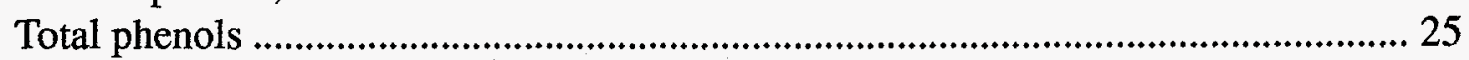

Quality assurance/quality control samples, blank samples....................................................... 25

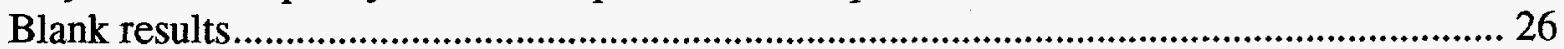

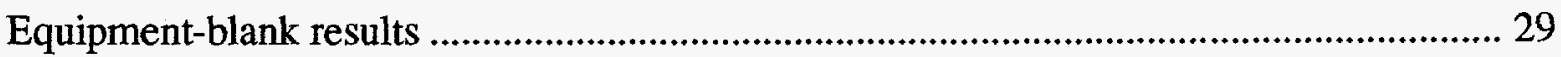

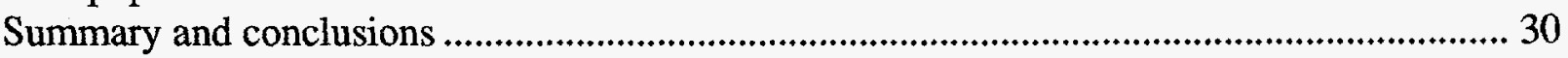

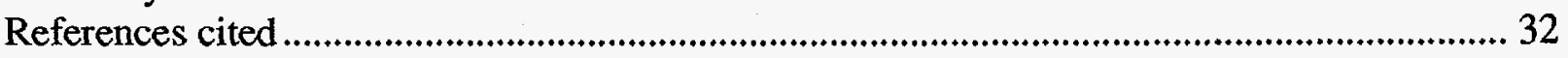

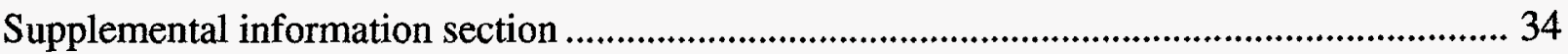




\section{ILLUSTRATIONS}

\section{Figures 1-3. Maps showing:}

1. Location of the Idaho National Engineering Laboratory, facilities, and surface-water sites sampled for the quality assurance/quality control program, Idaho National Engineering Laboratory, 1989 through 1993

2. Location of wells sampled for the quality assurance/quality control program, Idaho National Engineering Laboratory, 1989 through 1993

3. Location of wells at the Test Reactors Area, Idaho Chemical Processing Plant, Radioactive Waste Management Complex, and Naval Reactors Facility sampled for the quality assurance/quality control program, Idaho National Engineering Laboratory, 1989 through 1993

Figures 4-8. Graphs showing:

4. Results of statistical comparisons of replicate pairs of samples analyzed for major ions

5. Results of statistical comparisons of replicate pairs of samples analyzed for nutrients.

6. Results of statistical comparisons of replicate pairs of samples analyzed for trace elements

7. Results of statistical comparisons of replicate pairs of samples analyzed for gross radioactivity and radionuclides.

8. Results of statistical comparisons of replicate pairs of samples analyzed for organic constituents

\section{TABLES}

1. Laboratories and respective analyses performed for the water-quality monitoring program at the Idaho National Engineering Laboratory

2. Sample containers, preservatives, and treatments for analyses of inorganic constituents in water samples from the Idaho National Engineering Laboratory

3. Sample containers, preservatives, and treatments for analyses of gross radioactivity and radionuclides in water samples from the Idaho National Engineering Laboratory

4. Sample containers, preservatives, and treatments for analyses of organic constituents in water samples from the Idaho National Engineering Laboratory

5. Analytical methods used to determine inorganic constituents in water samples from the Idaho National Engineering Laboratory, with detection limits or reporting levels 
6. Analytical methods used to determine gross radioactivity and radionuclides in water samples from the Idaho National Engineering Laboratory, with detection limits or reporting levels

7. Analytical methods used to determine organic constituents in water samples from the Idaho National Engineering Laboratory, and reporting levels

8. Identification, source, and description of blank waters for the water-quality monitoring program at the Idaho National Engineering Laboratory

9. Identification, source, and description of equipment blanks for the water-quality monitoring program at the Idaho National Engineering Laboratory.....

10. Comparison of results of replicate pairs of samples from the Idaho National Engineering Laboratory analyzed for sodium by the National Water Quality Laboratory and the Radiological and Environmental Sciences Laboratory....

11. Comparison of results of replicate pairs of samples from the Idaho National Engineering Laboratory analyzed for sulfate by the National Water Quality Laboratory

12. Comparison of results of replicate pairs of samples from the Idaho National Engineering Laboratory analyzed for chloride by the National Water Quality Laboratory and the Radiological and Environmental Sciences Laboratory....

13. Comparison of results of replicate pairs of samples from the Idaho National Engineering Laboratory analyzed for fluoride by the National Water Quality Laboratory 46

14. Comparison of results of replicate pairs of samples from the Idaho National Engineering Laboratory analyzed for bromide by the National Water Quality Laboratory 48

15. Comparison of results of replicate pairs of samplès from the Idaho National Engineering Laboratory analyzed for dissolved nitrite, as nitrogen, by the National Water Quality Laboratory.

16. Comparison of results of replicate pairs of samples from the Idaho National Engineering Laboratory analyzed for dissolved nitrite plus nitrate, as nitrogen, by the National Water Quality Laboratory

17. Comparison of results of replicate pairs of samples from the Idaho National Engineering Laboratory analyzed for dissolved ammonia plus organic nitrogen, as nitrogen, by the National Water Quality Laboratory

18. Comparison of results of replicate pairs of samples from the Idaho National Engineering Laboratory analyzed for dissolved ammonia, as nitrogen, by the National Water Quality Laboratory

19. Comparison of results of replicate pairs of samples from the Idaho National Engineering Laboratory analyzed for orthophosphate, as dissolved phosphorus by the National Water Quality Laboratory

20. Comparison of results of replicate pairs of samples from the Idaho National Engineering Laboratory analyzed for arsenic by the National Water Quality Laboratory 
21. Comparison of results of replicate pairs of samples from the Idaho National Engineering Laboratory analyzed for barium by the National Water Quality

Laboratory ...

22. Comparison of results of replicate pairs of samples from the Idaho National Engineering Laboratory analyzed for cadmium by the National Water Quality

Laboratory

23. Comparison of results of replicate pairs of samples from the Idaho National

Engineering Laboratory analyzed for chromium by the National Water Quality

Laboratory and the Radiological and Environmental Sciences Laboratory.

24. Comparison of results of replicate pairs of samples from the Idaho National

Engineering Laboratory analyzed for copper by the National Water Quality

Laboratory

25. Comparison of results of replicate pairs of samples from the Idaho National

Engineering Laboratory analyzed for iron by the National Water Quality

Laboratory

26. Comparison of results of replicate pairs of samples from the Idaho National Engineering Laboratory analyzed for lead by the National Water Quality

Laboratory

27. Comparison of results of replicate pairs of samples from the Idaho National .

Engineering Laboratory analyzed for manganese by the National Water Quality

Laboratory

28. Comparison of results of replicate pairs of samples from the Idaho National

Engineering Laboratory analyzed for mercury by the National Water Quality Laboratory

29. Comparison of results of replicate pairs of samples from the Idaho National Engineering Laboratory analyzed for nickel by the National Water Quality Laboratory

30. Comparison of results of replicate pairs of samples from the Idaho National Engineering Laboratory analyzed for selenium by the National Water Quality Laboratory.

31. Comparison of results of replicate pairs of samples from the Idaho National Engineering Laboratory analyzed for silver by the National Water Quality Laboratory.

32. Comparison of results of replicate pairs of samples from the Idaho National Engineering Laboratory analyzed for zinc by the National Water Quality Laboratory

33. Comparison of the results and standard deviations of replicate pairs of samples from the Idaho National Engineering Laboratory analyzed for gross alpha radioactivity, dissolved in water, as thorium-230 by the National Water Quality Laboratory.

34. Comparison of the results and standard deviations of replicate pairs of samples from the Idaho National Engineering Laboratory analyzed for gross alpha radioactivity, suspended in water, as thorium-230 by the National Water Quality Laboratory . 
35. Comparison of the results and standard deviations of replicate pairs of samples from the Idaho National Engineering Laboratory analyzed for gross alpha radioactivity, dissolved in water, as natural uranium by the National Water Quality Laboratory ......... 76

36. Comparison of the results and standard deviations of replicate pairs of samples from the Idaho National Engineering Laboratory analyzed for gross alpha radioactivity, suspended in water, as natural uranium by the National Water Quality Laboratory........ 77

37. Comparison of the results and standard deviations of replicate pairs of samples from the Idaho National Engineering Laboratory analyzed for gross alpha radioactivity by the Radiological and Environmental Sciences Laboratory

38. Comparison of the results and standard deviations of replicate pairs of samples from the Idaho National Engineering Laboratory analyzed for gross beta radioactivity, dissolved in water, as cesium-137 by the National Water Quality Laboratory....

39. Comparison of the results and standard deviations of replicate pairs of samples from the Idaho National Engineering Laboratory analyzed for gross beta radioactivity, suspended in water, as cesium-137 by the National Water Quality Laboratory.

40. Comparison of the results and standard deviations of replicate pairs of samples from the Idaho National Engineering Laboratory analyzed for gross beta radioactivity, dissolved in water, as strontium- $90 /$ yttrium- 90 by the National Water Quality Laboratory .

41. Comparison of the results and standard deviations of replicate pairs of samples from the Idaho National Engineering Laboratory analyzed for gross beta radioactivity, suspended in water, as strontium-90/yttrium-90 by the National Water Quality Laboratory ...

42. Comparison of the results and standard deviations of replicate pairs of samples from the Idaho National Engineering Laboratory analyzed for gross beta radioactivity by the Radiological and Environmental Sciences Laboratory

43. Comparison of the results and standard deviations of replicate pairs of samples from the Idaho National Engineering Laboratory analyzed for gamma radiation by the Radiological and Environmental Sciences Laboratory

44. Comparison of the results and standard deviations of replicate pairs of samples from the Idaho National Engineering Laboratory analyzed for radium-226 and radium- 228 by the National Water Quality Laboratory

45. Comparison of the results and standard deviations of replicate pairs of samples from the Idaho National Engineering Laboratory analyzed for strontium- 90 by the Radiological and Environmental Sciences Laboratory ....

46. Comparison of the results and standard deviations of replicate pairs of samples from the Idaho National Engineering Laboratory analyzed for tritium by the National Water Quality Laboratory and the Radiological and Environmental Sciences Laboratory ....

47. Comparison of the results and standard deviations of replicate pairs of samples from the Idaho National Engineering Laboratory analyzed for americium-241 by the Radiological and Environmental Sciences Laboratory . 
48. Comparison of the results and standard deviations of replicate pairs of samples from the Idaho National Engineering Laboratory analyzed for plutonium-238 by the Radiological and Environmental Sciences Laboratory

49. Comparison of the results and standard deviations of replicate pairs of samples from the Idaho National Engineering Laboratory analyzed for plutonium-239/240 by the Radiological and Environmental Sciences Laboratory

50. Comparison of results of replicate pairs of samples from the Idaho National Engineering Laboratory analyzed for total organic carbon by the National Water Quality Laboratory....

51. Comparison of results of replicate pairs of samples from the Idaho National Engineering Laboratory analyzed for volatile organic compounds by the National Water Quality Laboratory

52. Comparison of results of replicate pairs of samples from the Idaho National Engineering Laboratory analyzed for total phenols by the National Water Quality Laboratory

53. Results of blank and equipment blank samples from the Idaho National Engineering Laboratory analyzed for sodium, chloride, and chromium by the National Water Quality Laboratory and the Radiological and Environmental Sciences Laboratory

54. Results of blank and equipment blank samples from the Idaho National Engineering Laboratory analyzed for sulfate, fluoride, bromide, and total recoverable mercury by the National Water Quality Laboratory

55. Results of blank and equipment blank samples from the Idaho National Engineering Laboratory analyzed for nitrite, as nitrogen; nitrite plus nitrate, as nitrogen; ammonia, as nitrogen; and orthophosphate, as phosphorus by the National Water Quality Laboratory.

56. Results of blank and equipment blank samples from the Idaho National Engineering Laboratory analyzed for total recoverable trace elements: aluminum (Al), arsenic (As), barium (Ba), beryllium (Be), cadmium (Cd), copper ( $\mathrm{Cu})$, iron ( $\mathrm{Fe})$, lead $(\mathrm{Pb})$, manganese $(\mathrm{Mn})$, nickel (Ni), silver (Ag), and zinc ( $\mathrm{Zn})$ by the National Water Quality Laboratory

57. Results of blank and equipment blank samples from the Idaho National Engineering Laboratory analyzed for gross alpha and gross beta radioactivity by the National Water Quality Laboratory

58. Results of blank samples from the Idaho National Engineering Laboratory analyzed for radium-226 and radium-228 by the National Water Quality Laboratory

59. Results of blank and equipment blank samples from the Idaho National Engineering Laboratory analyzed for gamma radiation, strontium-90, and tritium by the National Water Quality Laboratory and the Radiological and Environmental Sciences Laboratory ...

60. Results of blank samples from the Idaho National Engineering Laboratory analyzed for americium-241, plutonium-238, and plutonium-239/240 by the Radiological and Environmental Sciences Laboratory 
61. Results of blank and equipment blank samples from the Idaho National Engineering Laboratory analyzed for organic constituents which exceeded the reporting level by the National Water Quality Laboratory

62. Upper-tail areas for a normal curve

63. Site identifiers and sampling dates for replicate sample pairs collected for analysis of specific types of organic constituents.

64. Organic compounds and respective reporting levels for the specific types of organic constituents in table 63 


\title{
Evaluation of the Quality Assurance/Quality Control Data Collected by the U.S. Geological Survey for Water-Quality Activities at the Idaho National Engineering Laboratory, Idaho, 1989 through 1993
}

\author{
by Linda M. Williams
}

\begin{abstract}
Hundreds of water samples were collected by the U.S. Geological Survey (USGS) from 177 monitoring sites for the water-quality monitoring program at the Idaho National Engineering Laboratory from 1989 through 1993. Concurrently, replicate pairs of samples and various types of blank samples were collected as part of the quality assurance/ quality control program. Analyses were performed to determine the concentrations of major ions, nutrients, trace elements, gross radioactivity and radionuclides, organic compounds, and total organic carbon in the samples.
\end{abstract}

To evaluate the precision of field and laboratory methods, analytical results of the replicate pairs of samples were compared statistically for equivalence on the basis of the precision associated with each result. Ninety percent or more of the analytical results for each constituent were equivalent, except for ammonia plus organic nitrogen, orthophosphate, iron, manganese, radium-226, total organic carbon, and total phenols.

Blank-sample analytical results indicated that the inorganic-free blank water from the USGS Quality of Water Service Unit and the deionized water from the USGS Idaho Falls Field Office were suitable source solutions for blanks. Waters from other sources were found to be unsatisfactory as blank source solutions.
Results of the analyses of several equipment blanks were evaluated to determine if a bias had been introduced and the possible sources of the bias. All of the equipment-blank analytical results indicated that ammonia concentrations were greater than the reporting level. None of the equipment blanks had measurable concentrations of radioactivity. Eight percent of the analyses for inorganic constituents showed measurable concentrations were present in the blanks, nine percent for radioactive constituents, and less than one percent for organic constituents.

\section{INTRODUCTION}

The Idaho National Engineering Laboratory (INEL) includes approximately $890 \mathrm{mi}^{2}$ of the eastern Snake River Plain in southeastern Idaho (fig. 1). The INEL was established in 1949 as the National Reactor Testing Station for nuclear-reactor research. Today, the U.S. Department of Energy (DOE) continues the reactor research along with numerous other projects, including defense programs, and environmental and waste remediation and research. Through the years, these activities have produced aqueous radioactive and chemical wastes that have been disharged into ponds and wells. Prior to 1984, most of the aqueous radioactive and chemical wastes generated at the INEL were injected directly into the Snake River Plain aquifer through deep wells. Since 1984, most of the aqueous 


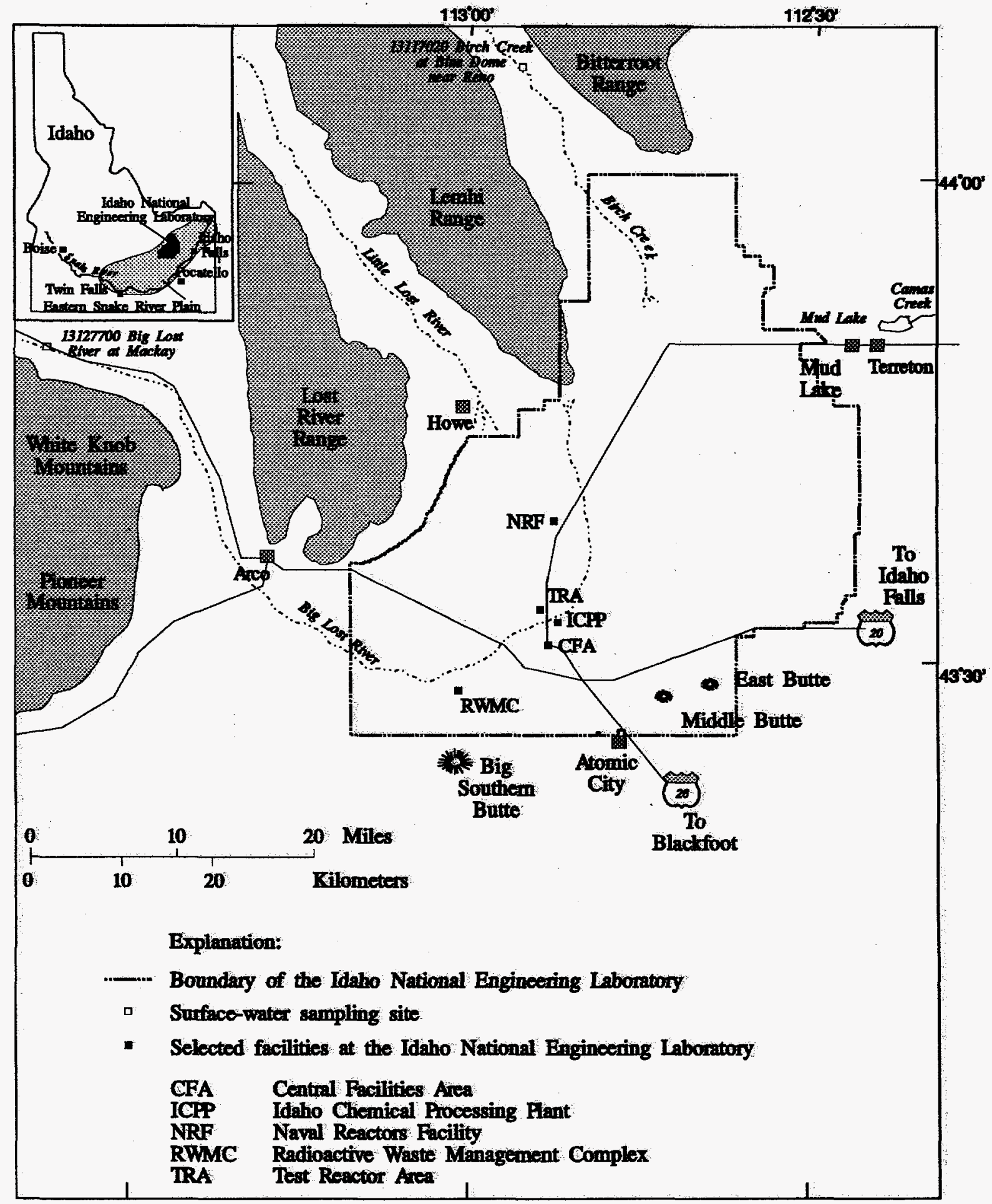

Figure 1. Locations of the Idaho National Engineering Laboratory, facilities, and surfacewater sites sampled for the quality assurance/quality control program, Idaho National Engineering Laboratory, 1989 through 1993. 
wastes have been discharged to unlined infiltration ponds. Many of the waste constituents have entered the aquifer after percolation through the unsaturated zone. The U.S. Geological Survey (USGS) conducts an extensive, ongoing water-quality monitoring program at 177 ground- and surface-water sites at the INEL in cooperation with the DOE. This program monitors effects of the waste disposal on the Snake River Plain aquifer. The information is provided to and used by many Federal and State government agencies and the general public.

\section{Purpose and Scope}

The purpose of this report is to present an evaluation of the data from the quality assurance/quality control (QA/QC) efforts of the water-quality monitoring program conducted by the USGS at the INEL from 1989 through 1993. Thousands of analytical results of replicate pairs are reported and compared for statistical equivalence. The replicate-pair analytical data and the results of the comparisons are compiled and tabulated along with the source-solution blank and equipment-blank analytical data. Evaluation of the results of the replicate pairs and the blank samples helps to assess precision and bias both in the field and in the laboratory. This not only validates the methods and procedures used at the INEL Project Office, but also allows for planning future QA/QC efforts.

Included in the report is a brief description of the methods and procedures used by field personnel for collection of replicate pairs of samples and preparation of blank samples. Locations of sampling sites and site identifiers are shown on figures 1-3. The laboratories involved in the project were the USGS National Water Quality Laboratory (NWQL) in Arvada, Colo., and the DOE Radiological and Environmental Sciences Laboratory (RESL) at the INEL. The laboratories and their respective analyses are listed in table 1 . The inorganic constituent analyses included major ions, nutrients, and trace elements. The gross radioactivity and radionuclide analyses included gross alpha radioactivity, gross beta radioactivity, gamma radiation, radium- 226 , radium- 228 , strontium- 90 , tritium, and transuranics. Analyses of organic constituents included total organic carbon, volatile organic compounds, semivolatile organic compounds, pesticides, gross polychlorinated compounds, Aroclors, and total phenols.

\section{Acknowledgments}

The author thanks employees of the USGS at the INEL Project Office and at the NWQL and the employees of DOE at the RESL who collected and analyzed the water samples described in this report. The author is especially grateful for the technical reviews by L.L. Knobel, M.A. Hardy, and E.J. Gilroy, all of the USGS.

\section{QUALITY ASSURANCE/QUALITY CONTROL PRACTICES}

The USGS is committed to collecting water samples that are as representative of the sampling site as possible and to reporting reliable and reproducible data. Guidelines that are specific to the USGS activities at the INEL have been set forth in the Quality Assurance Plan and Field Methods for Quality of Water Activities (L.J. Mann, USGS, written commun., 1989). This comprehensive plan defines the required procedures and tasks performed to ensure the reliability of waterquality data. It is available for inspection at the INEL Project Office. This plan is updated continually and a brief description of the tasks and procedures is included in this report. 


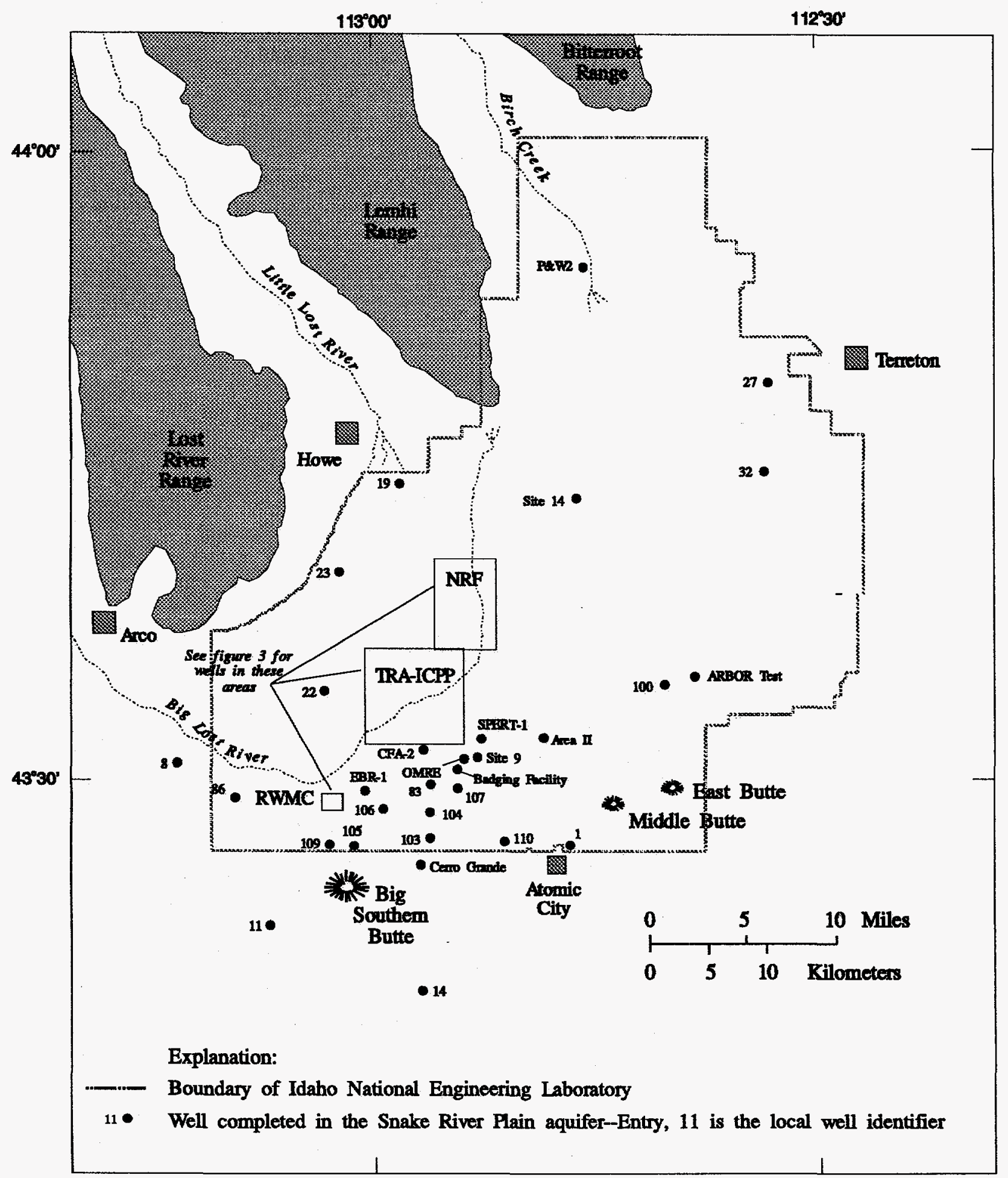

Figure 2. Locations of wells sampled for the quality assurance/quality control program, Idaho National Engineering Laboratory, 1989 through 1993 


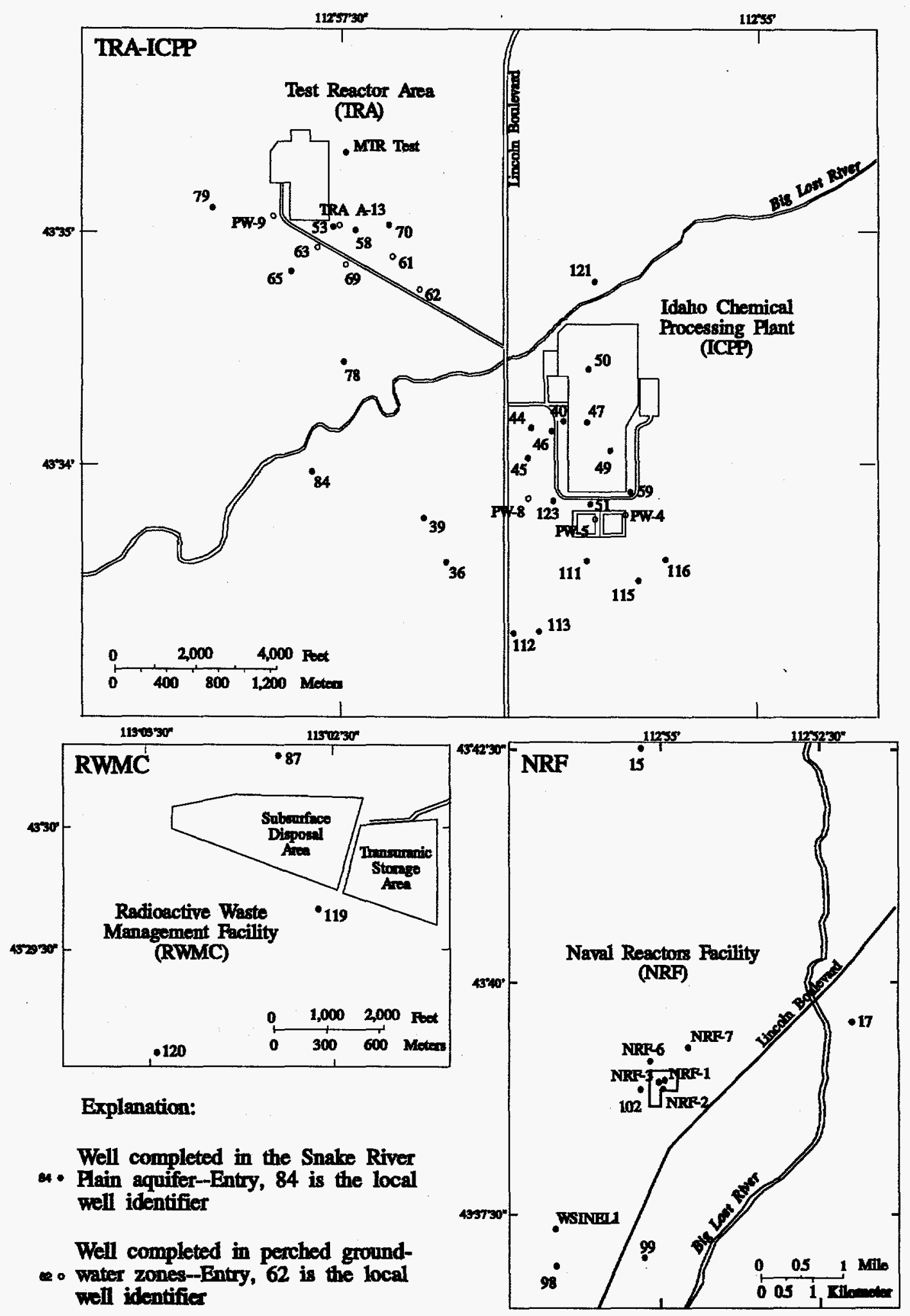

Figure 3. Locations of wells at the Test Reactor Area, Idaho Chemical Processing Plant, Radioactive Waste Management Complex, and Naval Reactors Facility sampled for the quality assurance/quality control program, Idaho National Engineering Laboratory, 1989 through 1993 
Table 1. Laboratories and respective analyses performed for the water-quality monitoring program at the Idaho National Engineering Laboratory

\begin{tabular}{|c|c|}
\hline Laboratory & Quantitative analyses performed \\
\hline \multirow[t]{3}{*}{ National Water Quality Laboratory } & $\begin{array}{l}\text { Inorganic constituents: major ions (sodium, sulfate, chloride, fluoride, } \\
\text { and bromide); nutrients (nitrite, nitrite plus nitrate, ammonia, ammonia } \\
\text { plus organic nitrogen, and orthophosphate); trace elements (aluminum, } \\
\text { arsenic, barium, beryllium, cadmium, chromium, copper, iron, lead, } \\
\text { manganese, nickel, silver, and zinc) }\end{array}$ \\
\hline & $\begin{array}{l}\text { Gross radioactivity and radionuclides: gross alpha, gross beta, radium- } \\
226 \text {, radium- } 228 \text {, and tritium }\end{array}$ \\
\hline & $\begin{array}{l}\text { Organic constituents: total organic carbon, volatile organic compounds, } \\
\text { semivolatile organic compounds, pesticides, gross polychlorinated } \\
\text { compounds, Aroclors, and total phenols }\end{array}$ \\
\hline \multirow[t]{2}{*}{$\begin{array}{l}\text { Radiological and Environmental } \\
\text { Sciences Laboratory }\end{array}$} & $\begin{array}{l}\text { Inorganic constituents: major ions (sodium and chloride); trace element } \\
\text { (chromium) }\end{array}$ \\
\hline & $\begin{array}{l}\text { Gross radioactivity and radionuclides: gross alpha, gross beta, gamma } \\
\text { radiation, strontium-90, tritium, americium- } 241 \text {, plutonium-238, and } \\
\text { plutonium-239/240 }\end{array}$ \\
\hline
\end{tabular}

Field personnel also take part in the National Field Quality Assurance Tests administered annually by the USGS (Erdmann and Thomas, 1985, p. 110-115). These tests are used to evaluate performance in making field measurements for $\mathrm{pH}$, specific conductivity, and alkalinity.

The part of the QA/QC program, from 1989 through 1993, that consisted of sending replicate pairs of samples and blank samples to the laboratories for analysis of specific constituents is described in this report. Analytical results for the replicate pairs were compared for statistical equivalence. The analytical results of the replicate pairs of samples and the statistical comparisons are presented in tables 10-52 in the Supplemental Information Section at the end of this report. The blank-sample results were evaluated and the data are presented in tables 53-61 in the same section.

\section{Sample Containers and Preservatives}

Sample containers and preservatives were supplied by the NWQL in accordance with the laboratory requirements specified by the NWQL Services Catalog (Pritt and Jones, 1989; A.C. Watterson and A.T. Kashuba, USGS, written commun., 1993). The laboratory's Quality Assurance/Quality Control Manual (Pritt and Raese, 1992) establishes the policies to ensure that the containers are free of contamination. The NWQL receives the required containers from suppliers, tests for contamination, and cleans the containers according to written procedures. Sample preservatives, which are prepared by contract suppliers for the NWQL, also are tested according to written procedures prior to shipping to field personnel. Sample containers, preservatives, and treatments for specific constituents are listed in tables 2-4. 
Table 2. Sample containers, preservatives, and treatments for analyses of inorganic constituents in water samples from the Idaho National Engineering Laboratory

[Abbreviations: NWQL, National Water Quality Laboratory; RESL, Radiological and Environmental Sciences Laboratory; $\mathrm{mL}$, milliliter. Except where noted, samples were acidified to 0.4 percent, volume per volume, with nitric acid]

\begin{tabular}{|c|c|c|c|}
\hline Inorganic constituent & Laboratory & Bottle size and type & Preservative, treatment, or both \\
\hline Sodium, dissolved ${ }^{1}$ & NWQL & 250-mL polyethylene & Filtered, acidified \\
\hline Sodium, total recoverable ${ }^{1}$ & NWQL & 250-mL polyethylene & Acidified \\
\hline $\begin{array}{l}\text { Sodium }^{2} \\
\text { Chloride }^{2}\end{array}$ & RESL & 500-mL polyethylene & Untreated \\
\hline $\begin{array}{l}\text { Sulfate, dissolved } \\
\text { Chloride, dissolved } \\
\text { Fluoride, dissolved } \\
\text { Bromide, dissolved }\end{array}$ & NWQL & 250-mL polyethylene & Filtered \\
\hline Nutrients, dissolved & NWQL & $\begin{array}{l}\text { 250-mL or } 125-\mathrm{mL} \text { brown } \\
\text { polyethylene }\end{array}$ & $\begin{array}{l}\text { Filtered, preserved with } 1 \mathrm{~mL} \text { or } \\
0.5 \mathrm{~mL} \text { of mercuric chloride, chilled }\end{array}$ \\
\hline $\begin{array}{l}\text { Chromium, total } \\
\text { recoverable }\end{array}$ & $\begin{array}{l}\text { NWQL } \\
\text { NWQL }\end{array}$ & $\begin{array}{l}250-\mathrm{mL} \text { polyethylene } \\
250-\mathrm{mL} \text { polyethylene }\end{array}$ & $\begin{array}{l}\text { Acidified } \\
\text { Filtered, acidified }\end{array}$ \\
\hline $\begin{array}{l}\text { Chromium, dissolved }{ }^{1,4} \\
\text { Chromium, hexavalent, }^{\text {dissolved }}{ }^{4}\end{array}$ & NWQL & 250-mL polyethylene & Filtered, acidified \\
\hline Chromium, dissolved & RESL & 100-mL polystyrene & $\begin{array}{l}\text { Filtered, acidified with } 1 \mathrm{~mL} \text { of } \\
\text { hydrochloric acid }\end{array}$ \\
\hline Trace elements, dissolved & NWQL & 250-mL polyethylene & Filtered, acidified \\
\hline $\begin{array}{l}\text { Trace elements, total } \\
\text { recoverable }\end{array}$ & NWQL & $500-\mathrm{mL}$ polyethylene & Acidified \\
\hline Mercury, dissolved & NWQL & 250-mL glass & $\begin{array}{l}\text { Filtered, preserved with } 10 \mathrm{~mL} \text { of } \\
\text { potassium dichromate }\end{array}$ \\
\hline Mercury, total recoverable & NWQL & 250-mL glass & $\begin{array}{l}\text { Preserved with } 10 \mathrm{~mL} \text { of potassium } \\
\text { dichromate }\end{array}$ \\
\hline
\end{tabular}

${ }^{1}$ The dissolved sodium sample also may be used for the dissolved chromium analysis; the sodium, total recoverable, sample may be used for the chromium, total recoverable, analysis.

${ }^{2}$ Samples to be analyzed for sodium, chloride, and tritium (table 3 ) by the RESL were collected in one bottle.

${ }^{3}$ Prior to October 1992, samples were collected in the larger bottle which required $1 \mathrm{~mL}$ of mercuric chloride as a preservative.

${ }^{4}$ The dissolved chromium and dissolved hexavalent chromium samples were collected in one bottle. 
Table 3. Sample containers, preservatives, and treatments for analyses of gross radioactivity and radionuclides in water samples from the Idaho National Engineering Laboratory

[Abbreviations: RESL, Radiological and Environmental Sciences Laboratory; NWQL, National Water Quality Laboratory; mL, milliliter; L, liter. Prior to October 1992, acidified samples analyzed by RESL were acidified to 2 percent, volume per volume $(\mathrm{v} / \mathrm{v})$, with hydrochloric acid; since then, samples were acidified to 0.4 percent $(\mathrm{v} / \mathrm{v})$ with nitric acid. Except where noted, all acidified samples analyzed by NWQL were acidified to 0.4 percent (v/v) with nitric acid]

\begin{tabular}{|c|c|c|c|}
\hline $\begin{array}{l}\text { Gross radioactivity } \\
\text { or radionuclide }\end{array}$ & Laboratory & Bottle size and type & Preservative, treatment, or both \\
\hline Gross alpha & RESL & 500-mL polyethylene & Acidified \\
\hline Gross alpha, dissolved & NWQL & 1-L polyethylene & Filter, acidified \\
\hline $\begin{array}{l}\text { Gross alpha, dissolved and } \\
\text { suspended }\end{array}$ & NWQL & 1-L polyethylene & Untreated \\
\hline Gross beta & RESL & 500-mL polyethylene & Acidified \\
\hline Gross beta, dissolved & NWQL & 1-L polyethylene & Filter, acidified \\
\hline $\begin{array}{l}\text { Gross beta, dissolved and } \\
\text { suspended }\end{array}$ & NWQL & $1-\mathrm{L}$ polyethylene & Untreated \\
\hline Gamma radiation & RESL & 500-mL polyethylene & Acidified \\
\hline $\begin{array}{l}\text { Radium-226 } \\
\text { Radium-228 }\end{array}$ & NWQL & 1-L polyethylene & $\begin{array}{l}\text { Filter, acidified with } \\
5 \mathrm{~mL} \text { of hydrochloric acid }\end{array}$ \\
\hline Strontium-90 & RESL & 500-mL polyethylene & Acidified \\
\hline Tritium 1 & $\begin{array}{l}\text { RESL } \\
\text { NWQL }\end{array}$ & $\begin{array}{l}125-\mathrm{mL} \text { or } 500-\mathrm{mL} \text { polyethylene } \\
250-\mathrm{mL} \text { or } 1-\mathrm{L} \text { polyethylene }\end{array}$ & $\begin{array}{l}\text { Untreated } \\
\text { Untreated }\end{array}$ \\
\hline $\begin{array}{l}\text { Americium-241 } \\
\text { Plutonium-238 } \\
\text { Plutonium-239/240 }\end{array}$ & RESL & 500-mL polyethylene & Acidified \\
\hline
\end{tabular}

${ }^{1}$ Samples to be analyzed for tritium, and sodium and chloride (table 2) by RESL were collected in one bottle.

Table 4. Sample containers, preservatives, and treatments for analyses of organic constituents in water samples from the Idaho National Engineering Laboratory

[Analyzing laboratory was the National Water Quality Laboratory. Abbreviations: $\mathrm{mL}$, milliliter; $\mathrm{L}$, liter]

\begin{tabular}{|c|c|c|}
\hline Organic constituent & Bottle size and type & Preservative, treatment, or both \\
\hline Total organic carbon & 125-mL amber glass & Unacidified, chilled \\
\hline Volatile organic compounds & 40-mL amber glass septum vials & Unacidified, chilled \\
\hline Semivolatile organic compounds & 1-L amber glass & Unacidified, chilled \\
\hline $\begin{array}{l}\text { Pesticides and gross polychlorinated } \\
\text { compounds }\end{array}$ & 1-L amber glass & Unacidified, chilled \\
\hline Aroclors & 1-L amber glass & Unacidified, chilled \\
\hline Total phenols & 1-L amber glass & $\begin{array}{l}\text { Preserved with } 10 \mathrm{~mL} \text { of } \\
\text { copper sulfate-phosphoric } \\
\text { acid solution, chilled }\end{array}$ \\
\hline
\end{tabular}




\section{Decontamination Procedures}

Equipment used to collect water samples from monitoring wells may become contaminated during the collection of previous samples; steps are taken to make certain the equipment is decontaminated. Most wells are equipped with dedicated pumps and only the discharge lines are moved from well to well; therefore, these lines are rinsed thoroughly with deionized water, inside and outside, between sampling sites. Subsequent flushing with at least three borehole volumes of sample water further decontaminates the discharge lines. Because the concentrations of most contaminants are greatest in wells nearest disposal sites and the concentrations decrease with increasing distance from the disposal sites, the most distant wells are sampled first. This process of sampling minimizes the possibility of cross-contamination between wells when portable equipment is used.

Wells not equipped with dedicated pumps are sampled either with a bailer or a portable submersible pump. The bailer is washed with warm water and detergent and rinsed with deionized water prior to use. In the past, the portable submersible pumps were flushed with several gallons of water from one of two wells, USGS 17 or USGS 97 . These wells have been periodically analyzed over the years and the concentrations of the constituents that could cause a bias in the analytical results have been well documented (Bartholomay and others, 1993, p. 24, 30-31). This practice was discontinued in May 1993 to further reduce the possibility of introducing unknown variables. Currently, the portable pumps are washed with warm water and detergent and rinsed with deionized water. At the sampling site, the pumps also are flushed with at least three borehole volumes of sample water.

All measuring and sampling equipment that comes into contact with the sample water is thoroughly rinsed with deionized water. The thermometers, probes, and electrodes of the $\mathrm{pH}$ meters and the specific conductivity meters are rinsed with deionized water and rinsed again with sample water so when measurements are made, the deionized water will not dilute the sample. Disposable latex gloves are worn, and changed when needed, to ensure that the samples are not contaminated by the field personnel themselves or cross-contaminated by preservatives or previous samples. Unless otherwise specified for a particular analysis or type of container, all the containers are rinsed with sample water, either filtered or unfiltered, as appropriate. The filtration apparatus used before July 1993 consisted of membrane filters placed in an acrylic holder. The holder was a potential source of contamination even though it was rinsed thoroughly with deionized water. To avoid contamination problems, the filters and holders were replaced by totally enclosed disposable capsule filters. Flexible tubing that connects the capsule filters to the sampling port at the well or to the peristaltic pump is thoroughly washed with water and detergent and rinsed with deionized water before use.

\section{Sample Collection}

The guidelines for water sample collection are being updated continually in accordance with new safety and environmental regulations and to accommodate the requirements of improved analytical procedures. Guidelines for field treatment of sample containers have been set forth in the NWQL Services Catalog (Pritt and Jones, 1989; A.C. Watterson and A.T. Kashuba, USGS, written commun., 1993). When field rinsing is required, the sample containers are rinsed three times with sample or deionized water before filling. The samples are untreated or filtered and preserved as established by the NWQL (Pritt and Jones, 1989; A.C. Watterson and A.T. Kashuba, USGS, written commun., 1993) or in the 
manner recommended by Bodnar and Percival (1982) depending upon the analyses requested. Although the sample collection procedures changed from 1989 through 1993, each sample of a replicate pair was always collected in the same manner.

Most sampling sites are wells with dedicated submersible pumps. Wells without dedicated pumps are sampled with bailers or portable pumps. Grab samples are collected at the seven surface-water sites.

The INEL Project Office maintains mobile field laboratories in which the supplies and equipment necessary for sampling are available for immediate sample processing. Field measurements are taken in this relatively clean and protected environment, and samples are preserved and prepared for shipping without delay.

At the INEL, special precautions are taken to ensure that the water samples are representative of the ground water at the sampling site. To achieve this, a volume of water equivalent to a minimum of three borehole volumes is pumped from each well. In addition, the temperature, $\mathrm{pH}$, and specific conductivity are monitored during pumping, using methods described by Wood (1981) and Hardy and others (1989). When the wells have been purged and measurements of these properties indicate probable hydraulic and chemical stability, field personnel collect the samples. Some wells do not contain or produce enough water to be purged three borehole volumes, so samples are collected from the bailer as soon as the temperature, $\mathrm{pH}$, and specific conductivity measurements stabilize.

Before July 1993, samples that required filtering were collected from a 4-L polyethylene container using a peristaltic pump. The 4-L container was rinsed thoroughly with the well water before being filled and allowed to overflow. The intake tubing of the peristaltic pump was rinsed with sample water and inserted into the container. A new 0.45-micron membrane filter was placed in the acrylic filter holder and rinsed with $750 \mathrm{~mL}$ of water. Because disposable capsule filters are used now, the filters are connected by tubing to the portable discharge line. At the few sites where a bailer is used or where grab samples are collected, the filters are connected by flexible tubing to the peristaltic pump. Regardless of the filtering technique, 1 liter of sample water is run through the capsule filter and tubing before the sample bottle is rinsed and filled. If the water at the sampling site contains large amounts of suspended material, it may be necessary to rinse the filter with 1 liter of deionized water, rather than with sample water, before the container is rinsed and filled. The bottles are then capped and transported into the field laboratory for preservation. After the sample is preserved, the bottles are recapped and labeled, and the caps are sealed with laboratory film.

To minimize analyte loss by biological processes or volatilization, samples for nutrient and organic constituent analyses are chilled to approximately $4^{\circ} \mathrm{C}$. The samples are kept on ice until they are received at the laboratory, where they are refrigerated.

All water samples are stored in the mobile field laboratory until they can be transferred to a secured storage area. After a sufficient number of samples is collected, and before any holding-time limitations are met, the samples are delivered to the appropriate laboratory for analysis. Holding-time limitations for the nutrients and organics constituents are 7 and 14 days, respectively. Samples for the NWQL are shipped by overnight-delivery mail in a sealed ice chest and usually are sent to the laboratory within 5 days of collection. The samples to be analyzed by the RESL are handcarried to the analytical chemistry area. 
Conditions during sample collection are recorded in a bound field logbook, and a chainof-custody form is used to track samples from the time of collection until delivery to the laboratory. These procedures were instituted in September 1987, and all records are available for inspection at the INEL Project Office.

\section{Analytical Methods and Reporting of Data}

Methods of detection or instrumentation used by the laboratories for each type of analysis and their corresponding detection limits or reporting levels are listed in tables 5-7.

Detection limits are used by the RESL. Because they are a function of sample matrix, sample size, and type of measurement, the limits are intended as guides to order-ofmagnitude sensitivities and can easily change by a factor of two or even more for the conditions specified (Bodnar and Percival, 1982, p. DL-1-1). With each analytical result, the RESL reports an analytical uncertainty. With each radiochemical result, the RESL reports a propagated random uncertainty, which is calculated using many variables, including the yields, appropriate half-lives, counting efficiencies, and count times. This uncertainty is one standard deviation as defined on the DOE, RESL Sample Record Sheet (ID F-5484.1A, written commun., Rev. 12-1988).

The NWQL uses reporting levels that are defined as the lowest measured concentration of a constituent that may be reliably reported using a given analytical method. Because of the unpredictable matrix effects on detection limits, the reporting limit is set somewhat higher than the detection limit (Pritt and Jones, 1989 , p. 1-6). For radiochemical results only, the NWQL reports a result and a value twice the standard deviation. Therefore, when comparing the results of analyses of gross radio- activity and radionuclides by the NWQL and the RESL, it is important to remember that two standard deviations are reported by the NWQL and one standard deviation is reported by the RESL.

\section{QUALITY ASSURANCE/QUALITY CONTROL SAMPLES, REPLICATE PAIRS OF SAMPLES}

Replicate pairs of samples were collected sequentially and sent to the same laboratory with different identifiers. For example, a sample collected from the well identified as USGS 36 may have a replicate sample identified as QA-4. There was no correlation between the identifier of the QA replicate and the routine water-quality sample; the field personnel selected a QA number sequentially during a sampling session and recorded that number in their field logbooks along with the required information about that particular site. This type of sample is useful in determining the laboratory's analytical reproducibility related to equipment, materials, or analysts. Replicate samples also can be used to measure the variability due to the collection process. Beginning in 1993, QA/QC samples were collected for comparison with routine water-quality samples that had been collected at the same site for the same constituents within the previous 24 hours. This type of QA/QC sample addresses variability related to ambient conditions at the site, field personnel, field-measurement instruments, and sampling equipment.

\section{Statistical Comparisons of Replicate Pairs of Samples}

If the standard deviations are known, it is possible to determine, within a specified confidence level, whether the results of a replicate pair of samples are statistically equivalent. When the standard deviations are unknown, 
Table 5. Analytical methods used to determine inorganic constituents in water samples from the Idaho National Engineering Laboratory, with detection limits or reporting levels

[Abbreviations: RESL, Radiological and Environmental Sciences Laboratory; NWQL, National Water Quality Laboratory; mg/L, milligram per liter; $\mu \mathrm{g} / \mathrm{L}$, microgram per liter]

\begin{tabular}{|c|c|c|c|}
\hline Inorganic constituent & Laboratory & Analytical method & $\begin{array}{l}\text { Detection limit }{ }^{1} \\
\text { or reporting level }^{2}\end{array}$ \\
\hline Sodium & $\begin{array}{l}\text { RESL } \\
\text { NWQL }\end{array}$ & $\begin{array}{l}\text { Ion selective electrode } \\
\text { Atomic absorption }\end{array}$ & $\begin{array}{l}2 \mathrm{mg} / \mathrm{L} \\
0.1 \mathrm{mg} / \mathrm{L}\end{array}$ \\
\hline Sulfate & $\begin{array}{l}\text { NWQL } \\
\text { NWQL }\end{array}$ & $\begin{array}{l}\text { Turbidimetry } \\
\text { Ion chromatography }\end{array}$ & $\begin{array}{l}1 \mathrm{mg} / \mathrm{L} \\
0.1 \mathrm{mg} / \mathrm{L}\end{array}$ \\
\hline Chloride & $\begin{array}{l}\text { RESL } \\
\text { NWQL } \\
\text { NWQL }\end{array}$ & $\begin{array}{l}\text { Ion selective electrode } \\
\text { Colorimetry } \\
\text { Ion chromatography }\end{array}$ & $\begin{array}{l}2 \mathrm{mg} / \mathrm{L} \\
0.1 \mathrm{mg} / \mathrm{L} \\
0.1 \mathrm{mg} / \mathrm{L}\end{array}$ \\
\hline Fluoride & $\begin{array}{l}\text { NWQL } \\
\text { NWQL }\end{array}$ & $\begin{array}{l}\text { Ion selective electrode } \\
\text { Ion chromatography }\end{array}$ & $\begin{array}{l}0.1 \mathrm{mg} / \mathrm{L} \\
0.1 \mathrm{mg} / \mathrm{L}\end{array}$ \\
\hline Bromide & NWQL & Ion chromatography & $0.01 \mathrm{mg} / \mathrm{L}$ \\
\hline Nutrients & NWQL & Colorimetry & $0.01-0.2 \mathrm{mg} / \mathrm{L}$ \\
\hline Trace elements & $\begin{array}{l}\text { NWQL } \\
\text { NWQL }\end{array}$ & $\begin{array}{l}\text { Atomic absorption } \\
\text { Inductively coupled plasma }\end{array}$ & $\begin{array}{l}1-10 \mu \mathrm{g} / \mathrm{L} \\
1-10 \mathrm{~g} / \mathrm{L}\end{array}$ \\
\hline Chromium & $\begin{array}{l}\text { RESL } \\
\text { NWQL } \\
\text { NWQL }\end{array}$ & $\begin{array}{l}\text { Atomic absorption } \\
\text { Direct current plasma } \\
\text { Atomic absorption }\end{array}$ & $\begin{array}{l}50 \mu \mathrm{g} / \mathrm{L} \\
1 \mu \mathrm{g} / \mathrm{L} \\
1 \mu \mathrm{g} / \mathrm{L}\end{array}$ \\
\hline Mercury & NWQL & Flameless atomic absorption & $0.1 \mu \mathrm{g} / \mathrm{L}$ \\
\hline
\end{tabular}

${ }^{1}$ RESL uses detection limits and NWQL uses reporting levels.

${ }^{2}$ Multiple reporting levels are dependent upon the constituent. 
Table 6. Analytical methods used to determine gross radioactivity and radionuclides in water samples from the Idaho National Engineering Laboratory, with detection limits or reporting levels

[Abbreviations: RESL, Radiological and Environmental Sciences Laboratory; NWQL, National Water Quality Laboratory; $\mathrm{pCi} / \mathrm{L}$, picocuries per liter]

\begin{tabular}{|c|c|c|c|}
\hline $\begin{array}{l}\text { Gross radioactivity } \\
\text { or radionuclide }\end{array}$ & Laboratory & Analytical method & $\begin{array}{l}\text { Detection limit } \\
\text { or reporting level }^{1}\end{array}$ \\
\hline Gross alpha & $\begin{array}{l}\text { RESL } \\
\text { NWQL }\end{array}$ & $\begin{array}{l}\text { Scintillation } \\
\text { Low background alpha-beta counter }\end{array}$ & $\begin{array}{l}3 \mathrm{pCi} / \mathrm{L} \\
0.6 \mathrm{pCi} / \mathrm{L}\end{array}$ \\
\hline Gross beta & $\begin{array}{l}\text { RESL } \\
\text { NWQL }\end{array}$ & $\begin{array}{l}\text { Low background beta counter } \\
\text { Low background alpha-beta counter }\end{array}$ & $\begin{array}{l}5 \mathrm{pCi} / \mathrm{L} \\
0.6 \mathrm{pCi} / \mathrm{L}\end{array}$ \\
\hline Gamma radiation & RESL & Gamma spectroscopy & $60 \mathrm{pCi} / \mathrm{L}$ \\
\hline Radium-226 & NWQL & Radon emanation & $2 \times 10^{-2} \mathrm{pCi} / \mathrm{L}$ \\
\hline Radium-228 & NWQL & Beta counting & $1 \mathrm{pCi} / \mathrm{L}$ \\
\hline Strontium-90 & RESL & Low background beta counter & $5 \mathrm{pCi} / \mathrm{L}$ \\
\hline Tritium & $\begin{array}{l}\text { RESL } \\
\text { NWQL }\end{array}$ & $\begin{array}{l}\text { Liquid scintillation } \\
\text { Enrichment, gas counting }\end{array}$ & $\begin{array}{l}200 \mathrm{pCi} / \mathrm{L} \\
0.1 \mathrm{pCi} / \mathrm{L}\end{array}$ \\
\hline Americium-241 & RESL & Alpha spectrometry & $6 \times 10^{-2} \mathrm{pCi} / \mathrm{L}$ \\
\hline Plutonium-238 & RESL & Alpha spectrometry & $4 \times 10^{-2} \mathrm{pCi} / \mathrm{L}$ \\
\hline Plutonium-239/240 & RESL & Alpha spectrometry & $4 \times 10^{-2} \mathrm{pCi} / \mathrm{L}$ \\
\hline
\end{tabular}

${ }_{1}$ RESL uses detection limits and NWQL uses reporting levels. 
Table 7. Analytical methods used to determine organic constituents in water samples from the Idaho National Engineering Laboratory, and reporting levels

[Analyzing laboratory is the National Water Quality Laboratory. Units: $\mathrm{mg} / \mathrm{L}$, milligram per liter; $\mu \mathrm{g} / \mathrm{L}$, microgram per liter]

\begin{tabular}{llc}
\hline \multicolumn{1}{c}{ Organic constituent } & \multicolumn{1}{c}{ Analytical method } & Reporting level $^{1}$ \\
\hline Total organic carbon & Wet oxidation & $0.1 \mathrm{mg} / \mathrm{L}$ \\
Volatile organic compounds & Gas chromatography/mass spectrometry & $0.2-20 \mu \mathrm{g} / \mathrm{L}$ \\
Semivolatile organic compounds & Gas chromatography/mass spectrometry & $5-30 \mu \mathrm{g} / \mathrm{L}$ \\
$\begin{array}{l}\text { Pesticides and gross } \\
\text { polychlorinated compounds }\end{array}$ & Gas chromatography & $0.01-1 \mu \mathrm{g} / \mathrm{L}$ \\
Aroclors & Gas chromatography & $0.1 \mu \mathrm{g} / \mathrm{L}$ \\
Total phenols & Colorimetry & $1 \mu \mathrm{g} / \mathrm{L}$ \\
\hline
\end{tabular}

${ }^{1}$ Multiple reporting levels are dependent upon the constituent.

approximations of the standard deviations are used for the statistical comparison. The comparison can be done using an adaptation of the equation to determine the standard deviate, $\mathrm{Z}$, or the number of standard deviations the variable deviates from the mean (Volk, 1969, p. 55), where $Z$ is the ratio of the absolute value of the difference of the two results and the square root of the sum of the squares of the standard deviations (the pooled standard deviation). In that way, a comparison can be made of two analytical results on the basis of the precision, or an approximation of the precision, associated with each of the results:

$$
Z=\frac{|x-y|}{\sqrt{\left(s_{x}\right)^{2}+\left(s_{y}\right)^{2}}}
$$

where

$x$ is the result of the routine waterquality sample, $y$ is the result of the QA/QC sample, $s_{x}$ is the standard deviation of $x$, and $s_{y}$ is the standard deviation of $y$.

When the population is distributed normally and the standard deviation is known, the analytical results of replicate pairs can be considered statistically equivalent at the 95-percent confidence level if the Z-value is less than or equal to 1.96 . When the population is not distributed normally or an approximation of the standard deviation is used, a Zvalue less than or equal to 1.96 must be considered a guide when testing for equivalence. At the 95-percent confidence level, the probability of error is 0.05 . In other words, when a $Z$-value is less than or equal to 1.96 , the results are within approximately two standard deviations of each other. Equation 1 is essentially the equation used to compare replicate data in the USGS protocol for collection and processing surface-water samples (Horowitz and others, 1995, p. 36). 
Instead of setting a value that is approximately equal to two standard deviations as a test of equivalence, the level of significance, or $p$-value, which indicates the weight of the evidence to reject the null hypothesis, $x \pm s_{x}=y \pm s_{y}$, may be determined. The null hypothesis is tested using the Z-value as the test statistic. The Z-value is calculated by using equation 1 , then the $p$-value is determined by referring to table 62 in the Supplemental Information Section. Assuming the distribution is normal, the $p$-value is the area under the curve for the $\mathrm{Z}$-value. The greater the Z-value, the smaller the $p$-value and the more likely that the results of the replicate pair are not equivalent, and the null hypothesis will be rejected. When $\mathrm{Z}=1.96$, the $p$-value $=$ 0.0250 for a one-tailed test and 0.0500 for a two-tailed test (table 62). This shows that these $p$-values are equivalent to the 95-percent confidence level and $\alpha=0.05$, where $\alpha$ is the probability that the null hypothesis will be rejected when true.

\section{Inorganic Constituents}

Equation 1 cannot be applied directly to the results when no standard deviations or uncertainties are reported. The analyses for inorganic constituents, which were done at the NWQL, were not reported with standard deviations; therefore, approximations of standard deviations were used. The USGS Branch of Quality Assurance (BQA) conducts a Blind Sample Program (BSP) in which reference samples disguised as environmental samples are submitted to the NWQL. A report by Maloney and others (1993) describes the program and evaluates the analytical results. The BSP data are stored in the QADATA program that is available through the USGS computer network (Lucey, 1990, p 1). The statistical analyses included in the program generate linear regression equations that allow the calculation of a most probable deviation (MPD) at any concentration for most analyses. A mini- mum MPD has been established for a few analyses at very low concentrations (Maloney and others, 1993, p. 4). The linear regression equations can be used to determine if the analytical results of the replicate pairs are statistically equivalent by calculating an MPD for each result and substituting for the standard deviation in equation 1. Because these are approximate standard deviations, the Z-value of 1.96 must be considered a guide when testing for equivalence.

The results of the replicate pairs of the inorganic constituent analyses and the Zvalues for each replicate pair are included in tables 10-32. If the analytical results of the pair were not statistically equivalent, that is, if the Z-value was greater than 1.96 , an "N" appears in the column labeled "Remark."

For many samples, the analytical results were less than the reporting level. If the results of both samples of the replicate pair were less than the reporting level, the results were assumed to be equivalent and the Z-value was reported as a zero. If, however, only one of the results was less than the reporting level, one of two approaches was taken.

First, if one result was less than the reporting level and the other exceeded the reporting level, the numerical value and the MPD of the numerical value of the reporting level were substituted in equation 1 for the result at the reporting level. For example, the analytical results of fluoride in the replicate pair collected at USGS 97 on June 7, 1990, were $<0.1 \mathrm{mg} / \mathrm{L}$ and $0.4 \mathrm{mg} / \mathrm{L}$ (table 13 ). Using the minimum MPD of $0.075 \mathrm{mg} / \mathrm{L}$ that has been set for this analysis (Maloney and others, 1993), the results were $0.1 \pm 0.075 \mathrm{mg} / \mathrm{L}$ and $0.4 \pm 0.075 \mathrm{mg} / \mathrm{L}$. The $\mathrm{Z}$-value, calculated from equation 1 , equaled 2.83 . The $Z$-value was greater than 1.96 and, therefore, was outside the 95-percent confidence interval. The 
results of the replicate pair were not equivalent and an "N" appears in the column labeled "Remark."

Second, if one result was less than the reporting level and the other was at the reporting level, the MPD of the result was calculated at the reporting level using the linear regression equation for that analysis. It is impractical to use equation 1 because the $\mathrm{Z}$-value will always equal zero. Therefore, to compare the two results using the precision associated with them, the deviation was multiplied by 1.96 . If the range of the deviation had included zero, the results would have been equivalent because any result less than the reporting level was included in the 95-percent confidence interval. For example, the analytical results of fluoride analyses of the replicate pair collected at USGS 12 on June 15, 1990, were $<0.1 \mathrm{mg} / \mathrm{L}$ and $0.1 \mathrm{mg} / \mathrm{L}$ (table 13 ). The linear regression equation generated an MPD of $0.018 \mathrm{mg} / \mathrm{L}$, but a minimum MPD of $0.075 \mathrm{mg} / \mathrm{L}$ has been set for this analysis (Maloney and others, 1993, p. 5). Therefore, the result of $0.1 \mathrm{mg} / \mathrm{L}$ would have an MPD of $1.96 \times 0.075 \mathrm{mg} / \mathrm{L}$ at the 95-percent confidence level: $0.1 \pm 0.147$ $\mathrm{mg} / \mathrm{L}$. The range included zero and the results were considered equivalent. If the range had not included zero, as often is the case when the MPD is very small, equivalency could not have been determined and a " $U$ " would have appeared in the column labeled "Remark" signifying that equivalence was uncertain.

\section{Gross Radioactivity and Radionuclides}

The use of equation 1 is straightforward in determining if the results of radiochemical analyses of a replicate pair of samples were equivalent. Because the NWQL reported radiochemical results and two standard deviations, it was necessary to divide the value by two to compute the one standard deviation required by equation 1 . The results and reported standard deviations for the analyses of gross radioactivity and radionuclides in replicate pairs and the $\mathrm{Z}$-values are listed in tables 33-49. Calculations using equation 1 were performed on each replicate pair. If the analytical results of the pair were not statistically equivalent, an " $N$ " appears in the column labeled "Remark."

\section{Organic Constituents}

Organic constituents were not included in the BSP. Therefore, for total organic carbon and total phenol results, standard deviations were calculated from the relative standard deviations (RSD) reported by Wershaw and others (1987, p. 15-16) and in the NWQL Services Catalog (Pritt and Jones, 1989, p. 5-28) for these two types of analyses, respectively. The standard deviations of the volatile organic compounds were calculated from the RSD's provided by Rose and Schroeder (1995, p. 18-23). Analytical results for organic constituents are included in tables 50-52. Calculations using equation 1 were performed on each replicate pair and the Zvalues also are presented in the tables. If analytical results of the pair were not statistically equivalent, an "N" appears in the column labeled "Remark." If equivalence could not be determined, a " $U$ " appears in the column labeled "Remark" signifying that equivalence was uncertain. If the results of both samples of the replicate pair were less than the reporting level, the results were assumed to be equivalent and the $\mathrm{Z}$-value is reported as a zero.

More than 99 percent of the results of the 752 replicate pairs analyzed for volatile organic compounds were less than the reporting level and were considered equivalent. Only the replicate pairs analyzed for the volatile organic compounds, which were at or greater than the reporting levels, are tabulated (table 51). Because all 945 replicate pairs analyzed for semivolatile organic compounds, pesticides, gross polychlorinated compounds, and 
Aroclors were below the reporting level, and because the number of compounds was so large, the data also are not tabulated. The sites sampled and the corresponding volatile organic compound, semivolatile organic compound, pesticide, gross polychlorinated compounds, and Aroclor analyses are listed in table 63. The compounds included with each type of organic constituent are listed in table 64 .

\section{Summary of Statistical Comparisons of Replicate Pairs of Samples}

The statistical comparisons of the replicate pairs showed that for each constituent, except ammonia plus organic nitrogen, orthophosphate, iron, manganese, radium-226, total organic carbon, and total phenols, 90 percent or more of the results of the replicate pairs were equivalent. Lack of equivalence between results of replicate pairs indicates a problem. Because many factors, such as field methods, ambient conditions, laboratory procedures, and nonanalytical ${ }_{1}$ errors can affect precision, the source of the inconsistency cannot always be pinpointed.

The following sections summarize the statistical comparisons for each constituent. Graphical summaries are provided in figures 4-8.

\section{Inorganic Constituents}

Major ions.-Several replicate pairs of samples were analyzed by the NWQL for major ions. The major ions and the number of replicate pairs follow: sodium, 105 ; sulfate, 45; chloride, 207; fluoride, 45; and bromide, 29 . For all but the bromide analyses, the Zvalues were calculated with the analytical results and the MPD's determined with the regression equations formulated from the data collected by the BQA. Because the bromide analysis is not included in the BSP, an RSD of 15 percent (Pritt and Jones, 1989, p. 5-6) was used in equation 1.

Major ions analyzed and percentages of the analytical results of the replicate pairs that were equivalent follow: sodium, 94 percent; sulfate, 98 percent; chloride, 93 percent; fluoride, 96 percent; and bromide, 97 percent. The Z-values indicated that 25 replicate pairs analyzed for major ions were not equivalent and 431 pairs, or 94 percent of the results, were equivalent.

Nutrients.-Several replicate pairs of samples were analyzed by the NWQL for dissolved nutrients. The nutrients and the number of replicate pairs follow: nitrite, 61 ; nitrite plus nitrate, 68 ; ammonia plus organic nitrogen, 11; ammonia, 59; and orthophosphate, 64 . For all but the nitrite analyses, the $Z$-values were calculated with the analytical results and the MPD's determined with the regression equations formulated from the data collected by the BQA. Because the nitrite analysis is not included in the BSP, a standard deviation of $0.001 \mathrm{mg} / \mathrm{L}$ (Fishman, 1993, p. 147) was used for comparison in equation 1.

Nutrients analyzed and percentages of the analytical results of the replicate pairs that were equivalent, or that were uncertain follow: nitrite, 97 percent equivalent, 3 percent uncertain; nitrite plus nitrate, 96 percent equivalent; ammonia plus organic nitrogen, 82 percent equivalent, 9 percent uncertain; ammonia, 100 percent equivalent; and for orthophosphate, 84 percent equivalent, 9 percent uncertain. The $\mathrm{Z}$ values indicated that 8 replicate pairs analyzed for nutrients were not equivalent, 9 pair were uncertain, and 246 pairs, or 94 percent of the results, were equivalent.

Trace elements.--Several replicate pairs of samples were analyzed by the NWQL for trace elements; the analyses were for either dis- 


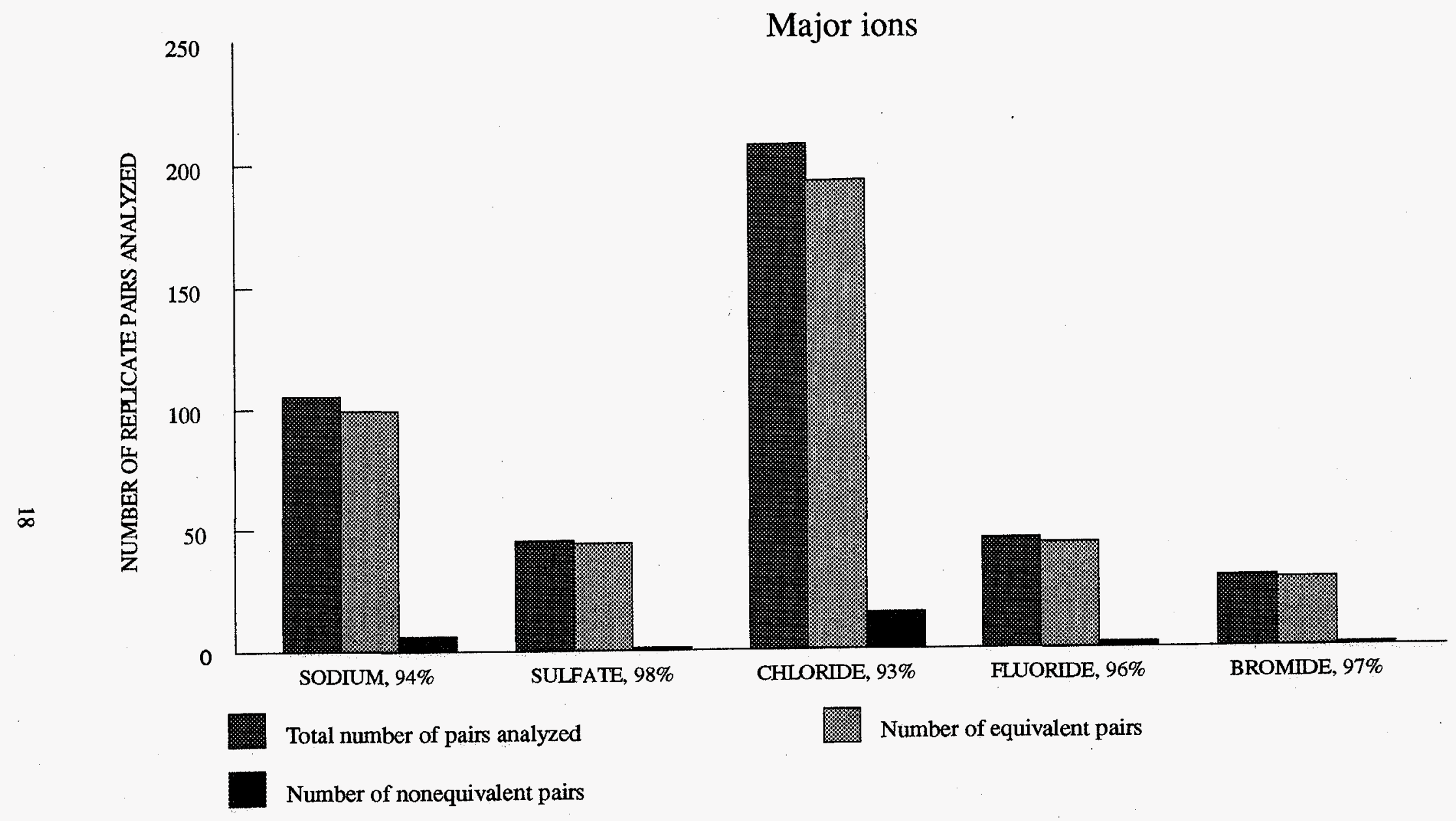

Explanation: Analytes are followed by the percentages of pairs that were equivalent.

Figure 4. Results of statistical comparisons of replicate pairs of samples analyzed for major ions 


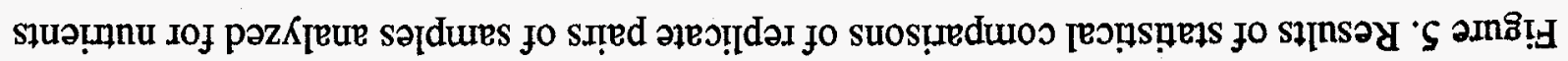

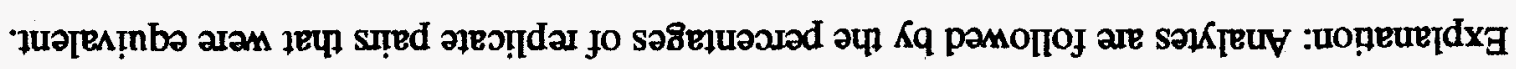

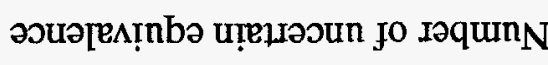

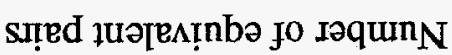

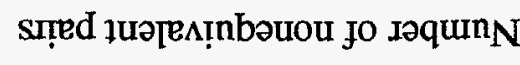

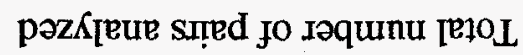

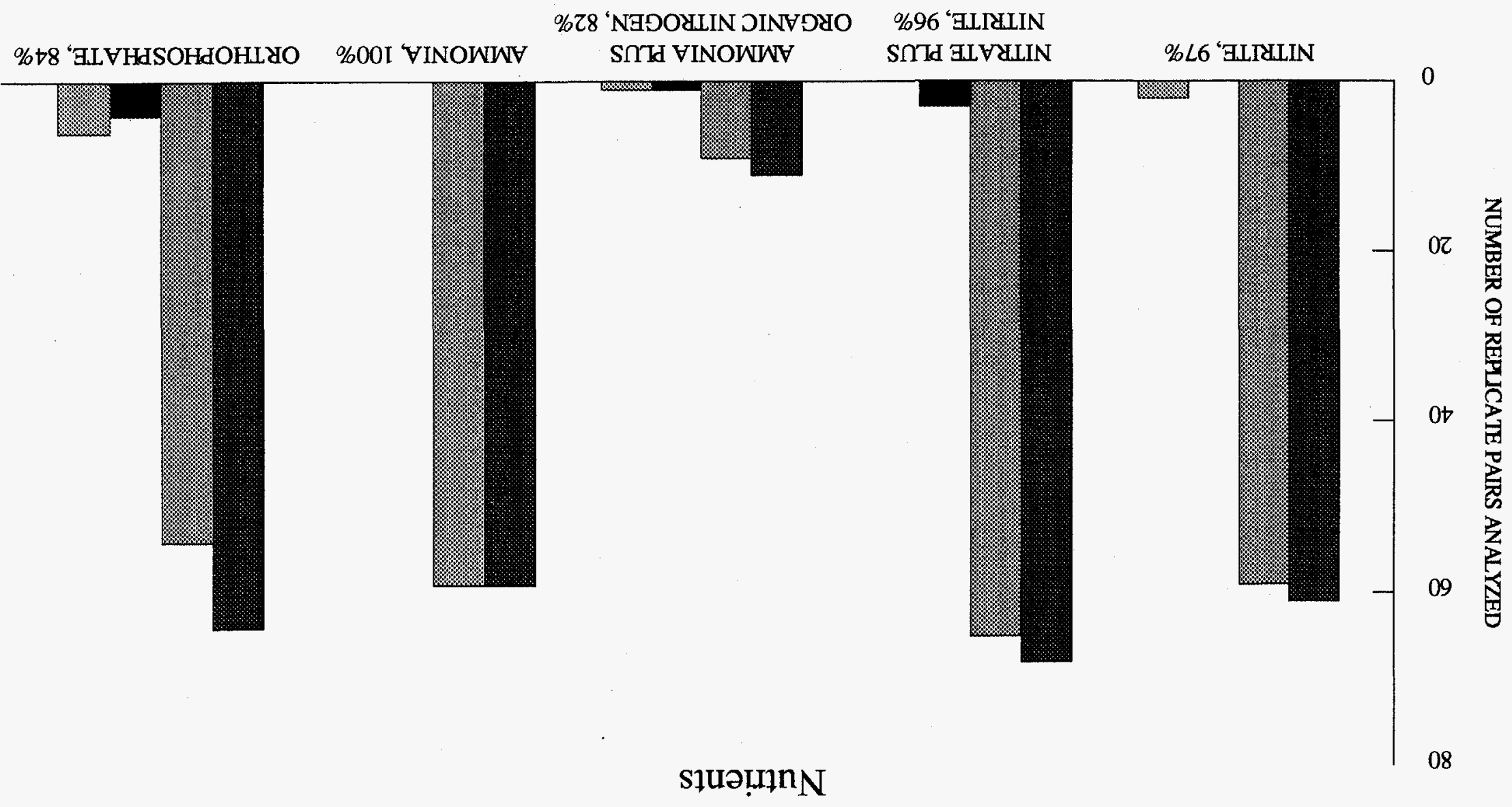

9 


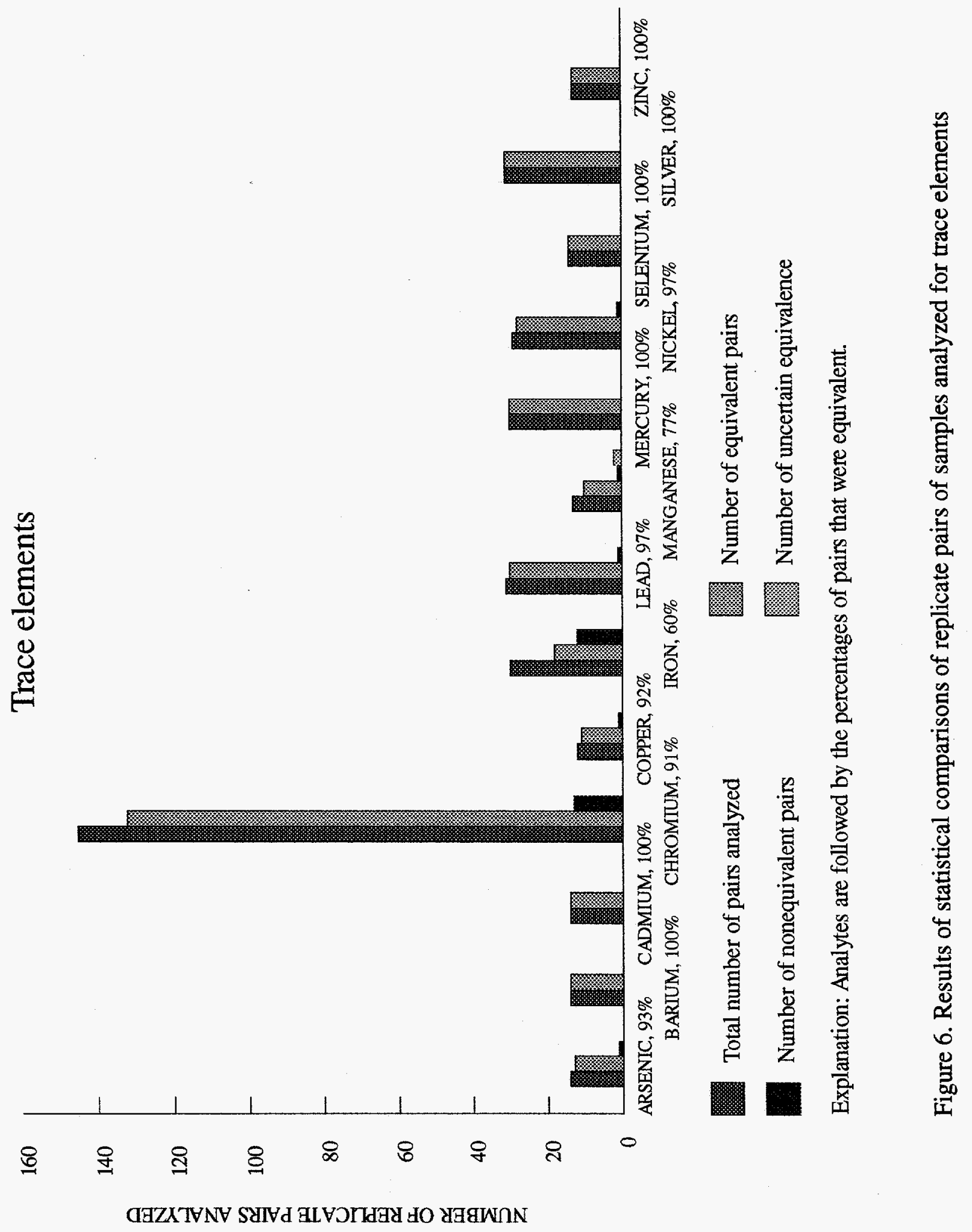




\section{Gross radioactivity and radionuclides}

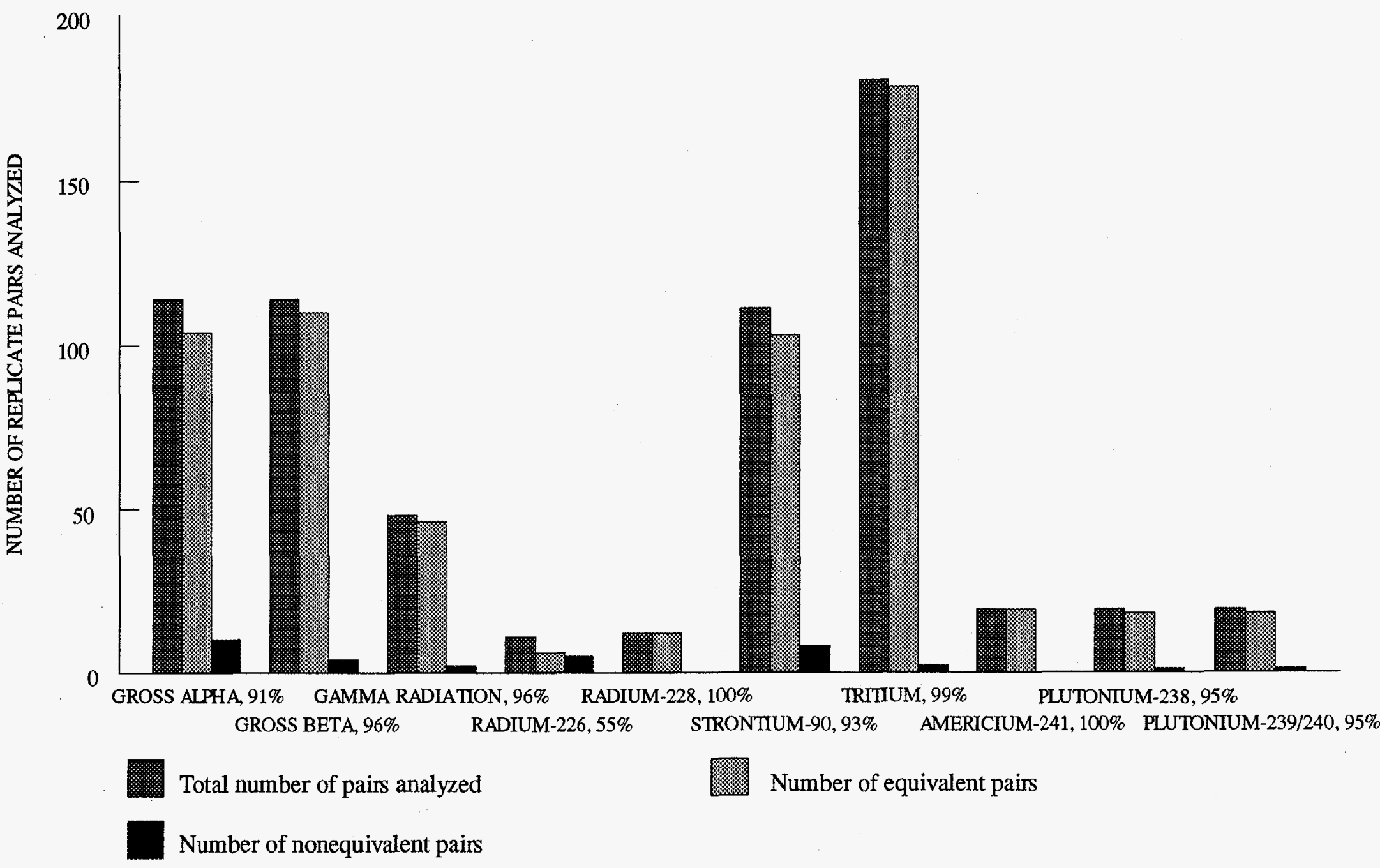

Explanation: Analytes are followed by the percentages of replicate pairs that are not equivalent.

Figure 7. Results of statistical comparisons of replicate pairs of samples analyzed for gross radioactivity and radionuclides 


\section{Organic constituents}

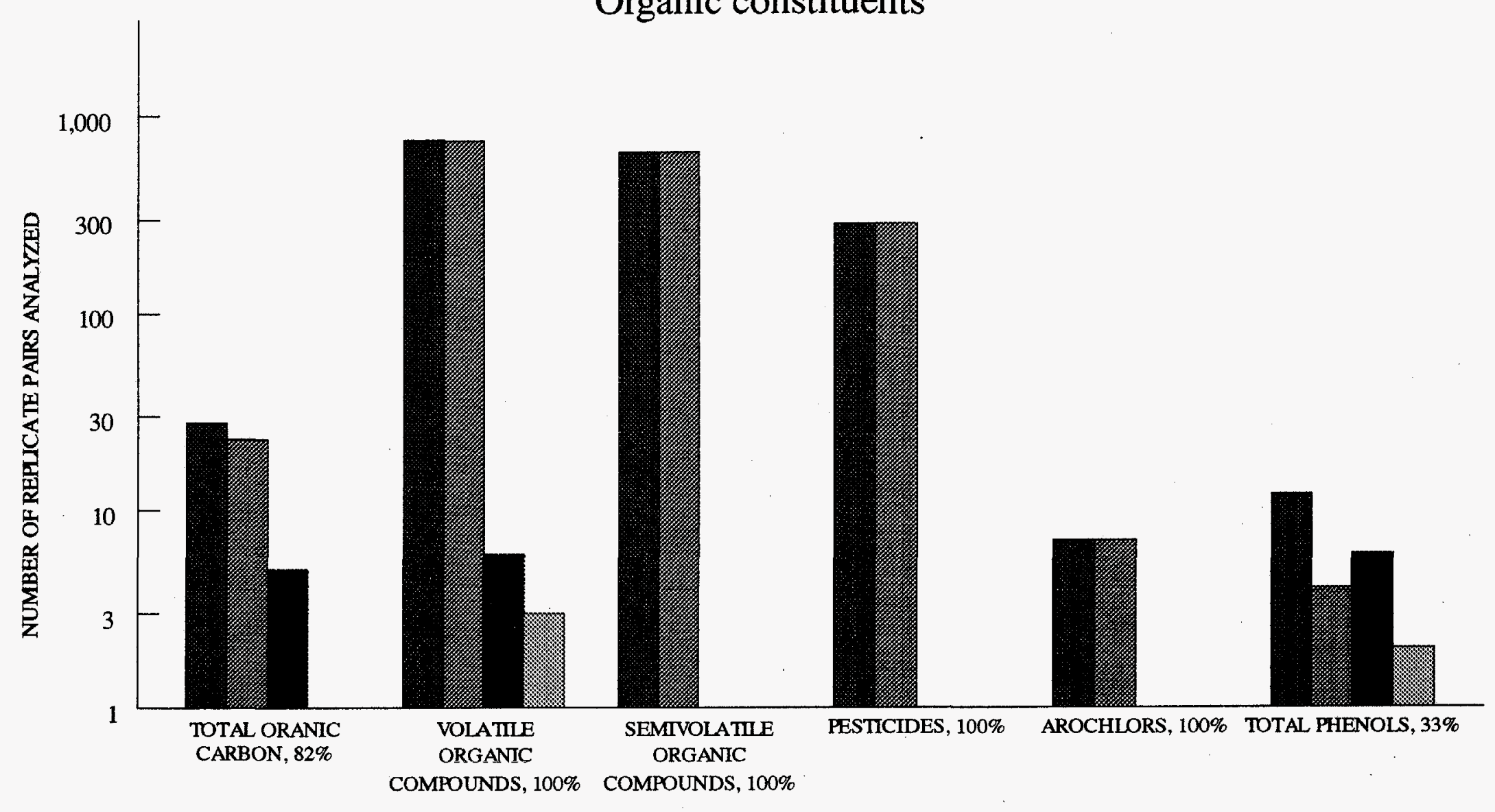

Number of equivalent pairs

Number of nonequivalent pairs

Number of uncertain equivalence

Explanation: Analytes are followed by the percentages of replicate pairs that are equivalent.

Figure 8. Results of statistical comparisons of replicate pairs of samples analyzed for organic constituents 
solved or total recoverable constituents. The trace element and the number of replicate pairs follow: arsenic, 14; barium, 14; cadmium, 14; chromium, 145; copper, 12; iron, 30; lead, 31; manganese, 13; mercury, 30; nickel, 29; selenium, 14; silver, 31; and zinc, 13. All the Z-values were calculated with the analytical results and the MPD's determined with the regression equations formulated from the data collected by the BQA.

Trace elements analyzed and percentages of the analytical results of the replicate pairs that were equivalent follow: arsenic, 93 percent; barium, 100 percent; cadmium, 100 percent; chromium, 91 percent; copper, 92 percent; iron, 60 percent; lead, 97 percent; manganese, 77 percent; mercury, 100 percent; nickel, 97. percent; selenium, 100 percent; silver, 100 percent; and zinc, 100 percent. The Z-values indicated that 30 replicate pairs analyzed for trace elements were not equivalent, 2 pairs that were analyzed for manganese were uncertain, and 358 pairs, or 92 percent of the results, were equivalent.

Statistical comparisons of the iron analyses indicated that only 60 percent of the results of the pairs were equivalent. The BQA also has noted significant lack of precision for the same procedure at the NWQL (Maloney and others, 1993, p. 11). Because the unfiltered samples collected at the INEL were for total recoverable iron, they may not have been representative samples owing to inhomogeneity of the water samples or contamination from the well structures. However, the samples analyzed for total recoverable iron in the BSP were split samples that were also analyzed for dissolved iron; the difference in the analyses was an added digestion procedure (Maloney and others, 1993, p. 3). This indicated that the lack of equivalence between replicate pairs analyzed for total recoverable iron partly resulted from laboratory conditions.
The argument that it may be difficult to compare replicate samples analyzed for a total recoverable constituent, rather than for the dissolved constituent, is valid. It is possible that sequential ground-water samples may be inhomogeneous because sediment is present in each sample of a replicate pair in different quantities or different compositions. Therefore, sediment may contribute in varying amounts to the concentration of the total recoverable constituent, and the results of the replicate pair would not be equivalent statistically.

Although the BQA indicated that a lack of precision has been shown for manganese (Maloney and others, 1993, p. 11), that conclusion could not be drawn from data collected at the INEL for the water-quality monitoring program. Sixty-two percent of the concentrations of total recoverable manganese were less than the reporting level and were considered equivalent. Equivalency of two of the pairs could not be determined. Concentrations in three pairs were greater than the reporting level; results of one pair were not equivalent. Although only 77 percent of the manganese results were equivalent, lack of precision was not necessarily indicated. More uncensored data are needed to make that determination; only the results of three replicate pairs were greater than the reporting level and could be compared statistically for this analysis.

\section{Gross radioactivity and radionuclides}

Gross alpha radioactivity.-There were 114 replicate pairs of samples analyzed by the NWQL and the RESL for gross alpha radioactivity. The NWQL reported results as gross alpha, dissolved as thorium-230, suspended as thorium-230, dissolved as natural uranium, and suspended as natural uranium. The RESL reported results as gross alpha radioactivity. 
The Z-values indicated that 10 replicate pairs were not equivalent and 104 pairs, or 91 percent of the results, were equivalent.

Gross beta radioactivity.-There were 114 replicate pairs of samples analyzed by the NWQL and the RESL for gross beta radioactivity. The NWQL reported results as gross beta, dissolved as cesium-137, suspended as cesium-137, dissolved as strontium-90/ yttrium-90, and suspended as strontium-90/ yttrium-90. The RESL reported results as gross beta radio-activity. The $\mathrm{Z}$-values indicated that 4 replicate pairs were not equivalent and 110 pairs, or 96 percent of the results, were equivalent.

Gamma radiation.-There were 48 replicate pairs of samples analyzed by the RESL for gamma radiation. The $\mathrm{Z}$-values indicated that 2 replicate pairs were not equivalent and 46 pairs, or 96 percent of the results, were equivalent.

Radium-226 and radium-228.-There were 12 replicate pairs of samples analyzed by the NWQL for radium-226 and radium-228. Eleven of the pairs were analyzed for radium226 and 12 for radium-228. The $\mathrm{Z}$-values indicated that 5 replicate pairs analyzed for radium-226 were not equivalent and 6 pairs, or 55 percent of the results, were equivalent. The Z-values indicated that all 12 pairs analyzed for radium-228, or 100 percent, were equivalent.

The replicate pairs analyzed for radium226 showed a significant lack of precision when compared statistically. These were anayzed for the dissolved constituent, rather than the total recoverable constituent; therefore, sample inhomogeneity was not the problem. Since all the radium-228 replicate pairs, which were collected sequentially with the radium226 pairs, were equivalent, it is unlikely that the inconsistencies were due to the sample collection process. No gross radioactivity or radionuclide analyses, including radium-226, are included in the BSP; therefore, the BQA does not review this analysis. The reason for the discrepancy could not be clearly defined.

Strontium-90.-There were 111 replicate pairs of samples analyzed by the RESL for strontium-90. The Z-values indicated that 8 replicate pairs were not equivalent and 103 pairs, or 93 percent of the results, were equivalent.

Tritium.-There were 180 replicate pairs of samples analyzed for tritium; 179 pairs were analyzed by the RESL, and 1 pair was analyzed by the NWQL. The Z-values indicated that 2 replicate pairs were not equivalent and 178 pairs, or 99 percent of the results, were equivalent.

Transuranics: americium-241, plutonium238. and plutonium-239/240.-There were 19 replicate pairs of samples analyzed by the RESL for three transuranic isotopes. The comparisons indicated that the results of all replicate pairs, but one, were equivalent for each isotope. The $\mathrm{Z}$-values indicated that 2 replicate pairs were not equivalent and 55 pairs, or 96 percent of the results, were equivalent.

\section{Organic constituents}

Total organic carbon.-There were 28 replicate pairs of samples analyzed by the NWQL for total organic carbon. For most analyses, an MPD derived from linear regression equations generated by the $\mathrm{BQA}$ from the BSP data or a reported standard deviation may be used to quantify the precision associated with the analytical results. Neither an MPD nor a standard deviation was available for analysis of total organic carbon.

The NWQL Services Catalog (Pritt and Jones, 1989) lists the RSD for total organic carbon as 6 percent. An RSD of 6 percent 
resulted in a precision estimate that indicated that only 29 percent of the replicate pairs were equivalent when equation 1 was applied.

The precision data for the dissolved organic carbon method (Wershaw and others, 1987 , p. 15), was used to determine a linear regression equation for calculating standard deviations at low concentrations because there is no precision data for the total organic carbon method. The precision statement for the total organic carbon method only states that the percent RSD for total organic carbon will be greater than that for dissolved organic carbon (Wershaw and others, 1987, p. 16). When using the analytical results and the standard deviations at low concentrations calculated with the linear regression equation, the $\mathrm{Z}$ values indicated that 5 replicate pairs were not equivalent and 23 pairs, or 82 percent of the results, were equivalent.

\section{Volatile organic compounds. - There were} 18 replicate pairs of samples analyzed by the NWQL for 36 volatile organic compounds. In 1992 , the volatile organic compound analyses included 25 additional compounds and in 1993, 2 more compounds were added. In the replicate pairs, only 9 of those 63 compounds were found with concentrations that were at or greater than the reporting level. Because neither an MPD nor a standard deviation was available for these nine volatile organic compounds, the standard deviations were calculated from the RSD's provided by Rose and Schroeder (1995). The following is a list of the compounds and the RSD's used to determine the standard deviations for the statistical comparisons: bromoform, 14 percent; bromodichloromethane, 8.3 percent; carbon tetrachloride, 8.4 percent; chloroform, 11 percent; dibromochloromethane, 17 percent; dichlorodifluoromethane, 11 percent; tetrachloroethylene, 12 percent; 1,1,1-trichloroethane, 12 percent; and trichloroethylene, 13 percent.
All the replicate pairs analyzed for the compounds with concentrations exceeding the reporting level were compared for statistical equivalence using equation 1 . Six replicate pairs were not equivalent and three pairs were uncertain. Four pairs of the results that were not equivalent were from one sample. Of the 752 comparisons, the $Z$-values indicated that 743 replicate pairs, or greater than 99 percent of the results, were equivalent.

Semivolatile organic compounds, pesticides, gross polychlorinated compounds, and Aroclors.-There were 12 replicate pairs of samples analyzed by the NWQL for 54 semivolatile organic compounds. In 1992, the semivolatile organic compound analyses included three additional compounds. The replicate pairs also were analyzed for 19 pesticides and for gross polychlorinated biphenyls and naphthalenes. One replicate pair was analyzed for an additional 32 pesticides and 7 Aroclors. All of the analytical results were less than the reporting level; therefore, 945 replicate pairs, or 100 percent of the results, were equivalent.

Total phenols.-There were 12 replicate pairs of samples analyzed by the NWQL for total phenols. This analysis is not included in the BSP; therefore, the comparisons of the results of the replicate pairs and the standard deviations were calculated using the RSD of 12 percent reported in the NWQL Services Catalog (Pritt and Jones, 1989, p. 5-49). Six replicate pairs were not equivalent and two pairs were uncertain. The Z-values indicated that 4 replicate pairs, or 33 percent of the results, were equivalent.

\section{QUALITY ASSURANCE/QUALITY CONTROL SAMPLES, BLANK SAMPLES}

Blank samples were prepared using inorganic-free blank water (IBW) from the Quality of Water Service Unit (QWSU) of the 
Office of Water Quality in Ocala, Fla; volatile organic compound blank water (VBW) from the NWQL; distilled, or distilled and deionized water from other sources; and water from USGS 17 and USGS 97 (fig. 3). There are several different kinds of blanks; examples are: source-solution, trip, and equipment.

A source solution is water that is free of the constituents of interest and is used as a stock solution for other blanks. For example, deionized water may be used to prepare an equipment blank of the filtration apparatus, and the source-solution blank would be a sample of the deionized water before it was filtered. Analytical results of a source-solution blank are used to determine the variability of methods or analysts within a laboratory. Also, they are used to determine whether the laboratory has introduced a bias into the analytical process. Furthermore, this type of blank is used to determine if, in fact, the source solution is free of contaminants.

Trip blanks travel with samples during collection, storage, and shipment to detect bias related to handling procedures or ambient conditions.

An equipment blank that has been run through all or part of the sampling apparatus can be used to detect a bias that has been introduced through use of that equipment. Equipment blanks can be used to identify contamination from the sample-collection or equipment-cleaning processes. Inorganic-free or deionized water is used at the present time for all equipment blanks. In the past, however, field personnel prepared equipment blanks for the portable pumps with well-characterized environmental water from USGS 17 and USGS 97 by rinsing the pumps with several volumes of the well water and collecting a sample to be analyzed for the constituents of interest.
Until October 1989, QA/QC samples were numbered using sequential site identifiers of nonexistent sites. Since then, sequential QA designations were given to QA/QC samples starting at QA-1 each sampling session; QAS designations were given to the Naval Reactors Facility QA/QC samples and were all numbered in sequence from QAS-1 to QAS-33; QAB1 was given to an equipment blank prepared between sampling sessions. Sources and descriptions of blanks and equipment blanks that were analyzed by both the NWQL and the RESL for the water-quality monitoring program are presented in tables 8-9. Analytical results of the blanks and equipment blanks are presented in tables 53-61.

Blanks should not have measurable concentrations of the constituents of interest. Measurable concentrations are those that exceed the reporting levels plus twice the MPD or standard deviation. The radiochemical concentrations of blanks should not exceed two standard deviations. Because USGS 17 and USGS 97 contain natural ground waters, those equipment blank results should not exceed the known concentrations of the constituents of interest plus twice the MPD or standard deviation.

\section{Blank Results}

The blanks obtained from the RESL and the Idaho Chemical Processing Plant (ICPP) were from the distilled and deionized water systems used by the analytical laboratories. The water samples were analyzed to determine if they would be appropriate for use as blank source solutions. The blanks from the RESL had measurable concentrations of tritium; this is due to tritium in the water supply at the Central Facilities Area where the RESL is located (Mann and Cecil, 1990). Radium-226, organic carbon, and phenols also were present in a RESL water sample. The blank from the ICPP had measurable concentrations of some 
Table 8. Identification, source, and description of blank samples for the water-quality monitoring program at the Idaho National Engineering Laboratory

[Site identifier: see section on Quality Assurance/Quality Control Samples, Blank Samples for explanation]

\begin{tabular}{|c|c|c|c|}
\hline $\begin{array}{c}\text { Site } \\
\text { identifier }\end{array}$ & $\begin{array}{c}\text { Date } \\
\text { prepared }\end{array}$ & Source & Description \\
\hline $\begin{array}{l}\text { USGS } 254 \\
\text { USGS } 288 \\
\text { USGS } 301 \\
\text { QAS-8 }\end{array}$ & $\begin{array}{l}02 / 17 / 89 \\
04 / 26 / 89 \\
06 / 30 / 89 \\
11 / 02 / 90\end{array}$ & $\begin{array}{l}\text { Radiological and Environmental Sciences } \\
\text { Laboratory }\end{array}$ & $\begin{array}{l}\text { Laboratory distilled and deionized } \\
\text { water }\end{array}$ \\
\hline QAS-1 & $12 / 01 / 89$ & Idaho Chemical Processing Plant & $\begin{array}{l}\text { Laboratory distilled and deionized } \\
\text { water }\end{array}$ \\
\hline $\begin{array}{l}\text { QA-7 } \\
\text { QA-1 }\end{array}$ & $\begin{array}{l}10 / 31 / 89 \\
09 / 25 / 90\end{array}$ & Grocery store & Bottled distilled water \\
\hline QA-5 & $05 / 07 / 93$ & $\begin{array}{l}\text { U.S. Geological Survey, } \\
\text { Idaho Falls Field Office }\end{array}$ & Deionized water \\
\hline $\begin{array}{l}\text { QAS-23 } \\
\text { QA-16 }\end{array}$ & $\begin{array}{l}06 / 12 / 92 \\
11 / 12 / 92\end{array}$ & National Water Quality Laboratory & Volatile organic compound blank water \\
\hline
\end{tabular}

Table 9. Identification, source, and description of equipment-blank samples for the water-quality monitoring program at the Idaho National Engineering Laboratory

[Site identifier: see section on Quality Assurance/Quality Control Samples, Blank Samples for explanation]

\begin{tabular}{lccl}
\hline $\begin{array}{c}\text { Site } \\
\text { identifier }\end{array}$ & $\begin{array}{c}\text { Date } \\
\text { prepared }\end{array}$ & Source & Description \\
\hline QAB-1 & $02 / 21 / 92$ & OmniSolv $^{(8)}$ water & Rinsate of filtering apparatus \\
& & & \\
QA-5 & $07 / 14 / 92$ & $\begin{array}{c}\text { Inorganic-free water from the } \\
\text { Quality Water Service Unit }\end{array}$ & $\begin{array}{c}\text { Rinsate of sampling equipment and filtering } \\
\text { apparatus }\end{array}$ \\
QA-6 & $08 / 13 / 92$ & \\
QA-15 & $10 / 22 / 92$ & & \\
QA-10 & $04 / 29 / 93$ & & \\
QA-15 & $04 / 30 / 93$ & & \\
QAS-30 & $06 / 15 / 93$ & & Rinsate of sampling equipment and filtering \\
QA-3 & $07 / 06 / 93$ & & apparatus \\
QA-2 & $07 / 06 / 93$ & Deionized water from the & \\
QA-1 & $07 / 06 / 93$ & U.S. Geological Survey, & \\
QA-13 & $10 / 15 / 93$ & Idaho Falls Field Office & \\
QA-3 & $04 / 13 / 92$ & USGS 17 & \\
QA-3 & $08 / 07 / 92$ & & Rinsate of portable pumps \\
QA-8 & $10 / 16 / 92$ & & \\
QA-4 & $05 / 05 / 93$ & & \\
QA-2 & $09 / 16 / 91$ & USGS 97 & \\
QA-3 & $10 / 21 / 91$ & & \\
QA-6 & $01 / 21 / 92$ & & \\
QA-5 & $01 / 21 / 92$ & &
\end{tabular}


total recoverable trace elements, gross radioactivity and radionuclides, and organic compounds. The trace elements present were aluminum, copper, iron, lead, and zinc. Radiochemical analyses revealed the presence of gross alpha radioactivity, gross beta radioactivity, radium-226, radium-228, and tritium. Also present were bis(2-ethylhexyl) phthalate and phenols. These two sources are unsuitable for use as blank source solutions.

The two samples of bottled distilled water obtained from grocery stores were relatively free of the constituents of interest. One sample had small concentrations of sodium and chloride that were greater than the reporting level but within twice the MPD's. The other had a measurable concentration of ammonia. Radiochemical analyses indicated that no radionuclides were present. These samples were not analyzed for trace elements, gross radioactivity, or organic compounds. However, because it is difficult to ensure the purity of water from so many different sources, the use of this type of water is discouraged except in an emergency situation (D. Rickert, USGS, written commun., 1992).

The deionized water from the Idaho Falls Field Office had small concentrations of methylene chloride and toluene; these samples were not analyzed for trace elements and nutrients. The Idaho Falls Field Office is located some distance from the INEL Project Office; therefore, the distilled water is transported to the INEL in large polyethylene containers and stored until needed. It is unclear whether the small concentrations of the two volatile organic compounds were due to the water, to contact with the container, or to the shipping and storage processes.

Two VBW samples from the NWQL were analyzed, one for inorganic constituents and the other for organic compounds. This type of blank source solution is expected to be free of volatile organic compounds but not necessarily free of inorganic constituents. One blank, QAS-23, had small concentrations of sodium, chloride, and bromide; no analyses were requested for organic constituents. Methylene chloride was detected in the other sample, QA-16, which was analyzed only for volatile organic compounds.

In summary, 8 blanks were analyzed for sodium, 9 for chloride, and 11 for chromium; there were no measurable concentrations of these constituents except for sodium in one result. Three blanks were analyzed for sulfate, fluoride, bromide, and total recoverable mercury; there were no measurable concentrations of these constituents except for bromide in one result. Analytical results indicated that concentrations of ammonia in three of five blanks were greater than the reporting level; all but one were within twice the MPD. Three blanks were analyzed for total recoverable trace elements; measurable concentrations of aluminum, copper, iron and zinc were found in QAS-1. The same three blanks were analyzed for gross alpha radioactivity and gross beta radioactivity; only QAS-1 had concentrations greater than two standard deviations. Measurable concentrations of radium were detected in QAS-1 from the ICPP (radium-226 and radium-228) and QAS-8 from the RESL (radium-226). Several blanks were analyzed for other radionuclides: 2 for gamma radiation, 4 for strontium-90, 6 for tritium, and 2 for transuranics. No radioactivity greater than two standard deviations was detected except in water from the ICPP and the RESL, which had measurable concentrations of tritium. Several blanks were analyzed for organic compounds and four of them had measurable concentrations of some organic compounds. Bis(2ethylhexyl) phthalate and phenols were in the blank from the ICPP. Total organic carbon and phenols were in the blank from the RESL. Methylene chloride was in two other blanks; also, toluene was in one of the two. 
For most of the blanks, the results of ammonia analyses were greater than the reporting level but within twice the MPD. Although the statistical comparisons indicated that the results of 100 percent of the replicate pairs of samples were equivalent, the data showed that the ammonia concentrations of the blanks and the routine water-quality samples were essentially the same. The positive bias, evidenced by the number of blank results that were greater than the reporting level, may be due to either sample collection or analytical methods. The situation has been noted and documented by the BQA and is being addressed by the laboratory (A. Lutke, USGS, written commun., 1993).

\section{Equipment-Blank Results}

Several source solutions have been used for equipment blanks: commercially available OmniSolv ${ }^{\circledR}$ water; IBW from the QWSU; deionized water from the USGS Idaho Falls Field Office; and water from USGS 17 and USGS 97 at the INEL. The equipment-blank source solutions were passed through and collected from different sampling apparatus in the same manner as the routine water-quality samples. Then, the blanks were analyzed for the constituents of interest to determine if the sampling process had introduced a bias to the analytical results.

Ten equipment blanks were analyzed for sodium, 18 for chloride, and 29 for chromium. There were no measurable concentrations of these constituents except for sodium in one blank. Only one equipment blank, QAS-30, which was an IBW, was analyzed for sulfate, fluoride, bromide, and total recoverable mercury. The concentration of bromide was greater than the reporting level but was within twice the MPD. Five equipment blanks were analyzed for nutrients; except for QAS-15, all of the results for ammonia analyses were greater than the reporting level but were within twice the MPD. Analyses for QAS-15 indicated that the concentrations for all the nitrogen results were greater than the reporting levels. The blank, QAS-30, was analyzed for total recoverable iron, lead, nickel, and silver; measurable concentrations of iron and lead were detected. This same blank was analyzed for gross alpha radioactivity and gross beta radioactivity; no measurable concentrations of those constituents were detected. Nine equipment blanks were analyzed for gamma radiation, 16 for strontium-90, and 17 for tritium; no radioactivity greater than two standard deviations was detected. One equipment blank, QAB-1, was analyzed for organic compounds and only methylene chloride was detected.

Water from USGS 17 and USGS 97, which was used to prepare equipment blanks, has been analyzed over the years for sodium, chloride, chromium, and selected radioactive constituents for the water-quality monitoring program. A comparison of the results of the water from USGS 17 and USGS 97 as equipment blanks with the historical results as routine water-quality samples indicated that they were statistically equivalent except for sodium in one blank. The concentration of sodium in USGS 17 (QA-8) as an equipment blank was approximately twice that of USGS 17 as a routine water-quality sample. The means of the historical results and deviations of the means for sodium, chloride, and chromium in the water from USGS 17 and USGS 97 follow: USGS 17 had an average of $6.3 \pm 0.6 \mathrm{mg} / \mathrm{L}$ of sodium, $6.8 \pm 1.1 \mathrm{mg} / \mathrm{L}$ of chloride, and $2.4 \pm 3.4 \mu \mathrm{g} / \mathrm{L}$ of chromium; and USGS $97 \mathrm{had}$ an average of $15 \pm 1 \mathrm{mg} / \mathrm{L}$ of sodium, $33 \pm 3 \mathrm{mg} / \mathrm{L}$ of chloride, and $6.4 \pm 1.5$ $\mu \mathrm{g} / \mathrm{L}$ of chromium. Analyses indicated that no radioactive constituents were present in these well waters.

All the analytical results for gross radioactivity and radionuclides show that none were present in the equipment blanks. There was no evidence of radioactive contamination from 
the equipment used for previous water sampling or from ambient environmental conditions.

\section{SUMMARY AND CONCLUSIONS}

Water samples were collected by the USGS from 177 monitoring sites for the waterquality monitoring program at the INEL from 1989 through 1993. Several thousand analyses have been performed by the NWQL and the RESL to determine the concentrations of major ions, nutrients, trace elements, gross radioactivity and radionuclides, organic compounds, and total organic carbon in those waters. Concurrently, more than 3,000 analyses were performed on the replicate pairs of samples collected and blank samples prepared for the QA/QC program. The precision of field and laboratory methods can be assessed with the data from the analyses of the replicate pairs of samples. Although many factors may affect precision, the determination as to whether replicate pairs are equivalent, along with the BQA report concerning the NWQL (Maloney and others, 1993) and historical data, is useful in assessing sources of imprecision, bias, and, in some cases, inaccuracy.

To evaluate the precision of field and laboratory methods, analytical results of the replicate pairs of samples were tested statistically for equivalence on the basis of the precision associated with each result. Within the major ion analyses, 94 percent were equivalent; nutrients, 93 percent; trace elements, 92 percent; gross radioactivity and radionuclides, 95 percent; and organic constituents, 99 percent. In all, the statistical comparison of the data indicated that 96 percent of the replicate pairs were equivalent. The large percentage of analytical results of replicate pairs that were equivalent indicates that the samples were being collected in a manner that ensures the quality of the data.
Ninety percent or more of the analytical results for each constituent were equivalent when tested statistically except for some constituents of interest. Those constituents and the percentages of replicate pairs that were equivalent are ammonia plus organic nitrogen, 82 percent; orthophosphate, 84 percent; iron, 60 percent; manganese, 77 percent; radium- 226 , 55 percent; total organic carbon, 82 percent; and total phenols, 33 percent.

Lack of precision for analytical methods to determine the concentrations of iron and manganese has been documented by the BQA in the BSP. Although the statistical comparisons of the INEL replicate pairs analyzed for manganese seemed to indicate lack of precision, a closer look at the data shows that most results were below the reporting level and not enough data were available to concur with the BQA conclusion.

The BQA does not evaluate the methods used to determine radionuclides and the reason for the lack of equivalence between the replicate pairs analyzed for radium-226 could not be clearly defined. Because the analyses were done for the dissolved constituent, rather than the total recoverable constituent, and because the samples analyzed for radium-228, which were collected sequentially, were equivalent, it is unlikely that the inconsistencies were due to the sample collection process.

Neither an MPD nor a standard deviation was available for analysis of total organic carbon. The RSD of 6 percent reported in the NWQL Services Catalog (Pritt and Jones, 1989) indicated that only 29 percent of the replicate pairs were equivalent. An alternate method of determining the standard deviation, using precision data for the total organic carbon method (Wershaw and others, 1987, p. 15), indicated that 82 percent of the results were equivalent. 
The statistical comparisons of the analytical results for total phenols entailed using the RSD of 12 percent reported in the NWQL Services Catalog (Pritt and Jones, 1989). The results of the test indicated that only 33 percent of the replicate pairs analyzed for total phenols were equivalent. Because of the way the data were rounded, only the results of replicate pairs that were numerically the same could be considered equivalent at an RSD of 12 percent.

Blanks are an important component of the QA/QC program. The source-solution blank is water that is free of the constituents of interest and is used as a stock solution for other blank samples. Analytical results of a sourcesolution blank are used to determine variability or bias at the laboratory. Furthermore, this type of blank is used to determine if, in fact, the blank solution is free of contaminants. An equipment blank that has been passed through and collected from all or part of the sampling apparatus may be used to detect bias that may have been introduced through use of that equipment. Eight percent of the analyses for inorganic constituents showed measurable concentrations were present in the blanks, nine percent for radioactive constituents, and less than one percent for organic constituents.

Several sources were used for sourcesolution blanks: distilled and deionized water from the ICPP and the RESL analytical laboratories, bottled distilled water from grocery stores, deionized water from the Idaho Falls Field Office, and VBW from the NWQL. The blank samples obtained from the ICPP and the RESL were unsuitable for use as blank source solutions because they had measurable concentrations of constituents of interest. Tritium was a particularly unacceptable contaminant because it is part of the water molecule and cannot be removed. Distilled water from grocery stores may be used only in an emergency situation. The deionized water from the Idaho Falls Field Office was suitable for use as blank source solutions.

Additionally, the following sources were used for equipment blanks: commercially available OmniSolv ${ }^{\circledR}$ water; IBW from the QWSU; deionized water from the Idaho Falls Field Office; and well water from USGS 17 and USGS 97 at the INEL. Two equipment blanks had measurable concentrations of sodium. There was no evidence of radioactive contamination from the equipment used for previous water sampling or from ambient environmental conditions; all the analytical results for gross radioactivity and radionuclides showed none were detected in the equipment blanks.

Although statistical comparisons indicated that the results of replicate pairs analyzed for ammonia were 100 percent equivalent, most of the blank results were greater than the reporting level. The blank results were comparable to the routine water-quality sample results; that shows that there is a positive bias, which may be due to either sample collection or analytical methods.

Evaluation of the QA/QC data, the BQA report (Maloney and others, 1993), and historical data help to assess precision and bias of field methods at the INEL Project Office. The large percentage of replicate pairs of samples that are equivalent and of blank results that are free of the constituents of interest validates the methods and procedures and supports the reliability of the data. Furthermore, the QA/ QC data are useful in determining the source of inconsistencies when lack of equivalence between replicate pairs or blanks with measurable concentrations of the constituents of interest are detected. For example, when results of a specific analysis for several replicate pairs are not equivalent, and the results for other analyses of those pairs are equivalent, the source of the inconsistencies 
may be the laboratory proce-dures. On the other hand, when results of all the analyses for a replicate pair are not equivalent, the source of the inconsistencies may be the field procedures. In general, replicate samples do not address accuracy; but, a large Z-value, when the results of two replicate samples are tested statistically for equivalence, suggests that at least one of the samples is inaccurate.

\section{REFERENCES CITED}

Bartholomay, R.C., Knobel, L.L., and Tucker, B.J., 1993, Chemical constituents in water from wells in the vicinity of the Naval Reactors Facility, Idaho National Engineering Laboratory, Idaho 1990-91: U.S. Geological Survey Open-File Report 93-34 (DOE/ID22106), $70 \mathrm{p}$.

Bodnar, L.Z., and Percival, D.R., eds., 1982, Analytical Chemistry Branch Procedures Manual-Radiological and Environmental Sciences Laboratory: U.S. Department of Energy Report IDO-12096, variable pagination.

Erdmann, D.E., and Thomas, J.D., 1985, Quality assurance of U.S. Geological Survey waterquality field measurements, in Taylor, J.K., and Stanley, T.W., eds., Quality assurance for environmental measurements: Philadelphia, American Society for Testing and Materials, ASTM STP $867,441 \mathrm{p}$.

Fishman, M.J., ed., 1993, Methods of analysis by the U.S. Geological Survey National Water Quality Laboratory-Determination of inorganic and organic constituents in water and fluvial sediments: U.S. Geological Survey Open-File Report 93-125, 217 p.

Hardy, M.A., Leahy, P.P., and Alley, W.M., 1989, Well installation and documentation, and ground-water sampling protocols for the pilot National Water-Quality Assessment Program: U.S. Geological Survey Open-File Report 89-396, 36 p.
Horowitz, A.J., Demas, C.R., Fitzgerald, K.K., Miller, T.L., and Rickert, D.A., 1995, U.S. Geological Survey protocol for the collection and processing of surface-water samples for the subsequent determination of inorganic constituents in filtered water: U.S. Geological Survey Open-File Report 94-539, 57 p.

Lucey, K.J., 1990, QADATA User's Manual: An interactive computer program for the retrieval and analysis of the results from the external blind sample quality-assurance project of the U.S. Geological Survey: U.S. Geological Survey Open-File Report 90-162, 53 p.

Maloney, T.J., Lutke, A.S., and Krizman, T.L., 1993, Quality assurance for routine water analysis in the laboratories of the U.S. Geological Survey for water year 1990: U.S. Geological Survey Water-Resources Investigations Report 93-4082, $145 \mathrm{p}$.

Mann, L.J., and Cecil, L.D., 1990, Tritium in ground water at the Idlaho National Engi-neering Laboratory, Idaho: U.S. Geological Survey Water-Resources Investigations Report 90-4090 (DOE/ID-22090), 35 p.

Ott, R.L., 1993, An introduction to statistical methods and data analysis (4th ed.): Belmont, California, Wadsworth Publishing Company, $1183 \mathrm{p}$.

Pritt, J., and Jones, B.E., eds., 1989, 1990 National Water Quality Laboratory Services Catalog: U.S. Geological Survey Open-File Report 89-386, variable pagination.

Pritt, J.W. and Raese, J.W., eds., 1992, Quality Assurance/Quality Control Manual, National Water Quality Laboratory, U.S. Geological Survey Open-File Report 92-495, 33 p.

Rose, D.L., and Schroeder, M.P., 1995, Methods of analysis by the U.S. Geological Survey National Water Quality Laboratory- Determination of volatile organic compounds in water by purge and trap capillary gas chromatograph/mass spectrometry: U.S. Geological Survey Open-File Report 94-708, 26 p.

Volk, William, 1969, Applied statistics for engineers (2d ed.): New York, McGraw-Hill Book Company, 415 p. 
Wershaw, R.L., Fishman, M.J., Grabbe, R.R., and Lowe, L.L, eds., 1987, Methods for the determination of organic substances in water and fluvial sediments: Techniques of WaterResources Investigations of the U.S.

Geological Survey, book 5, chap. A3, 80 p.

Wood, W.W., 1981, Guidelines for collection and field analysis of ground-water samples for selected unstable constituents: U.S. Geological Survey Techniques of Water-Resources Investigations, book 1, chap. D2, 24 p. 
SUPPLEMENTAL INFORMATION SECTION 
Table 10. Comparison of results of replicate pairs of samples from the Idaho National Engineering Laboratory analyzed for sodium by the National Water Quality Laboratory and the Radiological and Environmental Sciences Laboratory

[Site identifier: see figures 1-3 for location of sites. QA: quality-assurance replicate sample. Z-value: see section on Statistical Comparisons of Replicate Pairs of Samples for explanation. Abbreviations: $\mathrm{mg} / \mathrm{L}$, milligram per liter; N, the analytical results are not in statistical agreement. Symbols: \#, the analysis was performed by the Radiological and Environmental Sciences Laboratory; *, the samples were analyzed for total recoverable sodium, rather than dissolved sodium; ${ }^{\otimes}$, the QA sample was collected within 24 hours]

\begin{tabular}{|c|c|c|c|c|c|}
\hline Site identifier & Date sampled & $\begin{array}{l}\text { Sodium } \\
(\mathrm{mg} / \mathrm{L})\end{array}$ & $\begin{array}{l}\text { Sodium QA } \\
\text { (mg/L) }\end{array}$ & Z-value & Remark \\
\hline Area II & $7 / 14 / 93$ & 17 & 15 & 1.70 & \\
\hline Cerro Grande & $10 / 18 / 9$ & 15 & 15 & .00 & \\
\hline CFA-2 & $7 / 25 / 91$ & 18 & 18 & .00 & \\
\hline \multirow[t]{2}{*}{ CPP 1} & $11 / 06 / 89$ & 7.9 & 7.7 & .28 & \\
\hline & $10 / 31 / 90$ & 8.0 & 7.8 & .28 & \\
\hline \multirow[t]{2}{*}{ CPP 2} & $1 / 31 / 89$ & ${ }^{\#} 6 \pm 2$ & $\#_{5 \pm 2}$ & .35 & \\
\hline & $4 / 29 / 92$ & 7.6 & 7.9 & .42 & \\
\hline CPP 4 & $7 / 23 / 90$ & 7.8 & 7.6 & .28 & \\
\hline CWP-4 & $4 / 25 / 89$ & ${ }^{\#} 13 \pm 2$ & ${ }^{\#} 16 \pm 2$ & .35 & \\
\hline EBR I & $4 / 28 / 89$ & ${ }^{\#} 7 \pm 2$ & ${ }^{\#} 7 \pm 2$ & .00 & \\
\hline Fire Station 2 & $10 / 08 / 92$ & 8.5 & 8.6 & .13 & \\
\hline MTR Test & $10 / 07 / 92$ & 23 & 23 & .00 & \\
\hline NRF-1 & 9/09/91 & *15 & $* 14$ & .92 & \\
\hline \multirow[t]{3}{*}{ NRF-2 } & $3 / 21 / 90$ & $* 17$ & $* 17$ & .00 & \\
\hline & $3 / 05 / 91$ & $* 20$ & *19 & .73 & \\
\hline & $9 / 15 / 93$ & *19 & $* 19$ & .00 & \\
\hline \multirow[t]{2}{*}{ NRF-3 } & $6 / 17 / 91$ & *13 & $* 13$ & .00 & \\
\hline & $12 / 03 / 92$ & *14 & $* 14$ & .00 & \\
\hline \multirow[t]{2}{*}{ NRF-4 } & $2 / 07 / 91$ & $* 14$ & $* 16$ & 1.79 & \\
\hline & $4 / 07 / 93$ & $* 17$ & *18 & .79 & \\
\hline NRF-6 & $3 / 10 / 92$ & $* 81$ & *82 & .20 & \\
\hline NRF-7 & $1 / 08 / 92$ & $* 8.1$ & $* 8.4$ & .41 & \\
\hline OMRE & $4 / 28 / 89$ & 7.0 & 7.0 & .00 & \\
\hline PW-1 & $10 / 27 / 89$ & 150 & 150 & .00 & \\
\hline PW-2 & $10 / 25 / 93$ & 180 & 180 & .00 & \\
\hline \multirow[t]{2}{*}{ PW-4 } & $10 / 17 / 90$ & 190 & 180 & .93 & \\
\hline & $10 / 22 / 92$ & 170 & 170 & .00 & \\
\hline PW-5 & $10 / 17 / 91$ & 160 & 160 & .00 & \\
\hline RWMC Prod. & $10 / 30 / 90$ & 7.9 & 8.2 & .41 & \\
\hline Site 9 & $9 / 27 / 91$ & 12 & 12 & .00 & \\
\hline \multirow[t]{2}{*}{ Site 14} & $10 / 18 / 91$ & 15 & 15 & .00 & \\
\hline & $11 / 04 / 93$ & 15 & 12 & 2.90 & $\mathbf{N}$ \\
\hline Site 19 & $10 / 01 / 90$ & 8.3 & 8.4 & .13 & \\
\hline SPERT-1 & $4 / 28 / 89$ & $\# 15 \pm 2$ & $\# 14 \pm 2$ & .35 & \\
\hline
\end{tabular}


Table 10. Comparison of results of replicate pairs of samples from the Idaho National Engineering Laboratory analyzed for sodium by the National Water Quality Laboratory and the Radiological and Environmental Sciences Laboratory-continued

\begin{tabular}{|c|c|c|c|c|c|}
\hline Site identifier & Date sampled & $\begin{array}{l}\text { Sodium } \\
(\mathrm{mg} / \mathrm{L})\end{array}$ & $\begin{array}{l}\text { Sodium QA } \\
\quad(\mathrm{mg} / \mathrm{L})\end{array}$ & Z-value & Remark \\
\hline TRA Disp. & $10 / 11 / 90$ & 11 & 11 & 0.00 & \\
\hline \multirow[t]{2}{*}{ TRA 3} & $4 / 27 / 89$ & $\# 7 \pm 2$ & $\# 7 \pm 2$ & .00 & \\
\hline & $11 / 02 / 92$ & 9.0 & 9.0 & .00 & \\
\hline \multirow[t]{2}{*}{ TRA 4} & $11 / 13 / 89$ & 6.9 & 7.7 & 1.17 & \\
\hline & $10 / 30 / 91$ & 7.6 & 7.9 & .42 & \\
\hline \multirow[t]{2}{*}{ WSINEL1 } & $12 / 07 / 90$ & $* 18$ & $* 18$ & .00 & \\
\hline & $12 / 03 / 91$ & *15 & $* 15$ & .00 & \\
\hline USGS 1 & $7 / 20 / 92$ & 16 & 15 & .87 & \\
\hline \multirow[t]{3}{*}{ USGS 12} & $6 / 15 / 90$ & $* 13$ & $* 13$ & .00 & \\
\hline & $9 / 06 / 91$ & $* 13$ & *14 & .97 & \\
\hline & $11 / 05 / 93$ & $* 16$ & *16 & .00 & \\
\hline \multirow[t]{2}{*}{ USGS 15} & $8 / 06 / 90$ & $* 18$ & $* 19$ & .76 & \\
\hline & $3 / 12 / 92$ & $* 5.7$ & $* 8.7$ & 4.40 & $\mathbf{N}$ \\
\hline \multirow[t]{2}{*}{ USGS 17} & $3 / 13 / 91$ & $* 5.6$ & $* 5.4$ & .34 & \\
\hline & $6 / 11 / 93$ & $* 5.6$ & $* 5.8$ & .34 & \\
\hline USGS 19 & $10 / 01 / 92$ & 12 & 12 & .00 & \\
\hline USGS 22 & $9 / 30 / 93$ & 21 & 21 & .00 & \\
\hline USGS 23 & $7 / 09 / 93$ & 8.7 & 9.4 & .90 & \\
\hline USGS 32 & $7 / 06 / 92$ & 18 & 18 & .00 & \\
\hline \multirow[t]{2}{*}{ USGS 35} & $10 / 07 / 91$ & 12 & 13 & 1.09 & \\
\hline & $10 / 20 / 93$ & 12 & $\otimes_{12}$ & .00 & \\
\hline USGS 37 & $10 / 21 / 93$ & 45 & 45 & .00 & \\
\hline USGS 38 & $10 / 14 / 92$ & 60 & 61 & .27 & \\
\hline USGS 40 & $10 / 18 / 89$ & 12 & 12 & .00 & \\
\hline \multirow[t]{2}{*}{ USGS 44} & $10 / 26 / 90$ & 8.6 & 8.5 & .13 & \\
\hline & $11 / 01 / 93$ & 8.8 & 8.4 & .53 & \\
\hline USGS 46 & $10 / 09 / 91$ & 11 & 10 & 1.16 & \\
\hline \multirow[t]{3}{*}{ USGS 54} & $11 / 03 / 89$ & 17 & 18 & .79 & \\
\hline & $10 / 16 / 92$ & 12 & 11 & 1.09 & \\
\hline & $10 / 13 / 93$ & 12 & 11 & 1.09 & \\
\hline USGS 56 & $11 / 15 / 89$ & 16 & 16 & .00 & \\
\hline \multirow[t]{2}{*}{ USGS 57} & $12 / 22 / 89$ & 29 & 28 & .53 & \\
\hline & $10 / 29 / 90$ & 38 & 37 & .42 & \\
\hline USGS 58 & $10 / 21 / 93$ & 9.9 & 34 & 14.54 & $\mathbf{N}$ \\
\hline \multirow[t]{2}{*}{ USGS 59} & $4 / 17 / 89$ & ${ }^{\#} 10 \pm 2$ & ${ }^{\#} 10 \pm 2$ & .00 & \\
\hline & $10 / 25 / 93$ & 23 & 23 & .00 & \\
\hline USGS 61 & $9 / 27 / 90$ & 15 & 14 & .92 & \\
\hline USGS 62 & $10 / 13 / 92$ & 15 & 14 & .92 & \\
\hline
\end{tabular}


Table 10. Comparison of results of replicate pairs of samples from the Idaho National Engineering Laboratory analyzed for sodium by the National Water Quality Laboratory and the Radiological and Environmental Sciences Laboratory-continued

\begin{tabular}{|c|c|c|c|c|c|}
\hline Site identifier & Date sampled & $\begin{array}{l}\text { Sodium } \\
\text { (mg/L) }\end{array}$ & $\begin{array}{l}\text { Sodium QA } \\
\text { (mg/L) }\end{array}$ & $Z$-value & Remark \\
\hline USGS 65 & $10 / 15 / 91$ & 13 & 13 & 0.00 & \\
\hline USGS 68 & $4 / 27 / 89$ & $\# 1,000 \pm 100$ & $\# 1,000 \pm 100$ & .00 & \\
\hline USGS 69 & $10 / 24 / 91$ & 10 & 10 & .00 & \\
\hline USGS 71 & $10 / 12 / 93$ & 12 & 12 & .00 & \\
\hline USGS 72 & $10 / 28 / 93$ & 34 & 15 & 1.92 & $\mathbf{N}$ \\
\hline \multirow[t]{2}{*}{ USGS 76} & $10 / 17 / 90$ & 9.4 & 9.0 & .51 & \\
\hline & $10 / 21 / 93$ & 9.5 & $\otimes_{9.2}$ & .38 & \\
\hline USGS 77 & $10 / 09 / 92$ & 32 & 32 & .00 & \\
\hline USGS 83 & $10 / 11 / 90$ & 9.9 & 9.9 & .00 & \\
\hline USGS 84 & $10 / 09 / 92$ & 9.4 & 9.4 & .00 & \\
\hline USGS 89 & $10 / 16 / 91$ & 19 & 19 & .00 & \\
\hline USGS 90 & $10 / 04 / 93$ & 11 & 8.0 & 3.70 & $\mathbf{N}$ \\
\hline \multirow[t]{4}{*}{ USGS 97} & $6 / 07 / 90$ & $* 15$ & $* 14$ & .92 & \\
\hline & $12 / 07 / 90$ & *13 & $* 14$ & .97 & \\
\hline & $6 / 07 / 91$ & *15 & $* 13$ & 1.88 & \\
\hline & $11 / 04 / 93$ & $* 15$ & *15 & .00 & \\
\hline \multirow[t]{2}{*}{ USGS 98} & $7 / 30 / 90$ & $* 8.1$ & $* 8.0$ & .14 & \\
\hline & $9 / 21 / 92$ & *8.6 & $* 11$ & 2.91 & $\mathbf{N}$ \\
\hline \multirow[t]{2}{*}{ USGS 99} & $10 / 03 / 90$ & $* 12$ & $* 11$ & 1.09 & \\
\hline & $6 / 16 / 92$ & *12 & *12 & .00 & \\
\hline USGS 100 & $10 / 05 / 92$ & 16 & 16 & .00 & \\
\hline \multirow[t]{2}{*}{ USGS 102} & $12 / 10 / 90$ & *13 & $* 14$ & .97 & \\
\hline & $12 / 09 / 92$ & $* 13$ & $* 13$ & .00 & \\
\hline \multirow[t]{2}{*}{ USGS 104} & $10 / 16 / 89$ & 8.3 & 8.2 & .14 & \\
\hline & $9 / 29 / 92$ & 8.5 & 8.6 & .143 & \\
\hline USGS 105 & $10 / 25 / 89$ & 12 & 13 & 1.02 & \\
\hline USGS 109 & $10 / 01 / 93$ & 11 & 11 & .00 & \\
\hline USGS 110 & $10 / 11 / 89$ & 16 & 16 & .00 & \\
\hline \multirow[t]{3}{*}{ USGS 114} & $10 / 05 / 89$ & 23 & 23 & .00 & \\
\hline & $9 / 24 / 90$ & 22 & 22 & .00 & \\
\hline & $10 / 21 / 91$ & 22 & 21 & .67 & \\
\hline USGS 116 & $10 / 05 / 89$ & 28 & 28 & .00 & \\
\hline USGS 122 & $10 / 15 / 91$ & 33 & 34 & .46 & \\
\hline
\end{tabular}


Table 11. Comparison of results of replicate pairs of samples from the Idaho National Engineering Laboratory analyzed for sulfate by the National Water Quality Laboratory

[Site identifier: see figures 1-3 for location of sites. QA: quality-assurance replicate sample. Z-value: see section on Statistical Comparisons of Replicate Pairs of Samples for explanation. Abbreviations: $\mathrm{mg} / \mathrm{L}$, milligram per liter; $\mathrm{N}$, the analytical results are not in statistical agreement]

\begin{tabular}{|c|c|c|c|c|c|}
\hline Site identifier & Date sampled & $\begin{array}{l}\text { Sulfate } \\
(\mathrm{mg} / \mathrm{L})\end{array}$ & $\begin{array}{l}\text { Sulfate QA } \\
\quad(\mathrm{mg} / \mathrm{L})\end{array}$ & $Z$-value & Remark \\
\hline Cerro Grande & $10 / 18 / 90$ & 18 & 18 & 0.00 & \\
\hline CPP 1 & $10 / 31 / 90$ & 27 & 27 & .00 & \\
\hline NRF-1 & $9 / 09 / 91$ & 36 & 39 & .74 & \\
\hline \multirow[t]{3}{*}{ NRF-2 } & $3 / 21 / 90$ & 52 & 51 & .20 & \\
\hline & $3 / 05 / 91$ & 52 & 53 & .20 & \\
\hline & $9 / 15 / 93$ & 51 & 53 & .41 & \\
\hline \multirow[t]{2}{*}{ NRF-3 } & $6 / 17 / 91$ & 38 & 38 & .00 & \\
\hline & $12 / 03 / 92$ & 41 & 41 & .00 & \\
\hline \multirow[t]{2}{*}{ NRF-4 } & $2 / 07 / 91$ & 45 & 38 & 1.62 & \\
\hline & $4 / 07 / 93$ & 46 & 46 & .00 & \\
\hline NRF-6 & $3 / 10 / 92$ & 230 & 220 & .66 & \\
\hline NRF-7 & $1 / 08 / 92$ & 19 & 19 & .00 & \\
\hline PW-2 & $1 / 08 / 91$ & 35 & 35 & .00 & \\
\hline PW-4 & $10 / 17 / 90$ & 25 & 29 & 1.16 & \\
\hline RWMC Prod. & $10 / 30 / 90$ & 26 & 29 & .86 & \\
\hline Site 19 & $10 / 01 / 90$ & 25 & 24 & .30 & \\
\hline TRA Disp. & $10 / 11 / 90$ & 40 & 45 & 1.15 & \\
\hline \multirow[t]{2}{*}{ WSINEL1 } & $12 / 07 / 90$ & 53 & 53 & .00 & \\
\hline & $12 / 03 / 91$ & 61 & 55 & 1.13 & \\
\hline \multirow[t]{3}{*}{ USGS 12} & $6 / 15 / 90$ & 32 & 30 & .54 & \\
\hline & $09 / 06 / 91$ & 29 & 32 & .82 & \\
\hline & $11 / 05 / 93$ & 35 & 36 & .28 & \\
\hline \multirow[t]{2}{*}{ USGS 15} & $8 / 06 / 90$ & 31 & 30 & .27 & \\
\hline & $3 / 12 / 92$ & 18 & 19 & .34 & \\
\hline \multirow[t]{2}{*}{ USGS 17} & $3 / 13 / 91$ & 19 & 18 & .34 & \\
\hline & $6 / 11 / 93$ & 19 & 19 & .00 & \\
\hline USGS 19 & $10 / 12 / 90$ & 25 & 25 & .00 & \\
\hline USGS 44 & $10 / 26 / 90$ & 24 & 23 & .31 & \\
\hline USGS 54 & $1 / 14 / 91$ & 280 & 280 & .00 & \\
\hline USGS 57 & $10 / 29 / 90$ & 32 & 33 & .27 & \\
\hline USGS 61 & $9 / 27 / 90$ & 150 & 140 & .96 & \\
\hline USGS 76 & $10 / 17 / 90$ & 26 & 26 & .00 & \\
\hline USGS 83 & $10 / 11 / 90$ & 23 & 21 & .64 & \\
\hline \multirow[t]{2}{*}{ USGS 97} & $6 / 07 / 90$ & 34 & 34 & .00 & \\
\hline & $12 / 07 / 90$ & 36 & 37 & .25 & \\
\hline
\end{tabular}


Table 11. Comparison of results of replicate pairs of samples from the Idaho National Engineering Laboratory analyzed for sulfate by the National Water Quality Laboratory-continued

\begin{tabular}{lccccc}
\hline Site identifier & Date sampled & $\begin{array}{c}\text { Sulfate } \\
(\mathrm{mg} / \mathrm{L})\end{array}$ & $\begin{array}{c}\text { Sulfate QA } \\
(\mathrm{mg} / \mathrm{L})\end{array}$ & Z-value & Remark \\
\hline USGS 97 - cont. & $6 / 07 / 91$ & 27 & 33 & 1.66 & \\
& $11 / 04 / 93$ & 36 & 36 & .00 & \\
USGS 98 & $7 / 30 / 90$ & 22 & 23 & .31 & \\
& $9 / 21 / 92$ & 23 & 21 & .64 & \\
USGS 99 & $10 / 03 / 90$ & 23 & 23 & .00 & \\
& $6 / 16 / 92$ & 27 & 26 & .29 & \\
USGS 100 & $1 / 07 / 91$ & 17 & 17 & .00 & $\mathrm{~N}$ \\
USGS 102 & $12 / 10 / 90$ & 160 & 33 & 15.02 & .00 \\
& $12 / 09 / 92$ & 36 & 36 & .00 & \\
USGS 104 & $1 / 10 / 91$ & 22 & 22 & .00 \\
\hline
\end{tabular}


Table 12. Comparison of results of replicate pairs of samples from the Idaho National Engineering Laboratory analyzed for chloride by the National Water Quality Laboratory and the Radiological and Environmental Sciences Laboratory

[Site identifier: see figures 1-3 for location of sites. QA: quality-assurance replicate sample. Z-value: see section on Statistical Comparisons of Replicate Pairs of Samples for explanation. Abbreviations: mg/L, milligram per liter; N, the analytical results are not in statistical agreement. Symbol: \#, the analysis was performed by the Radiological and Environmental Sciences Laboratory; ${ }^{\otimes}$, the QA sample was collected within 24 hours]

\begin{tabular}{|c|c|c|c|c|c|}
\hline Site identifier & Date sampled & $\begin{array}{c}\text { Chloride } \\
\text { (mg/L) }\end{array}$ & $\begin{array}{c}\text { Chloride QA } \\
(\mathrm{mg} / \mathrm{L})\end{array}$ & Z-value & Remark \\
\hline ARBOR Test & $10 / 01 / 91$ & 15 & 17 & 1.40 & \\
\hline Area II & $7 / 14 / 93$ & 17 & 16 & .69 & \\
\hline Badging Facility & $4 / 19 / 90$ & 18 & 17 & .66 & \\
\hline Big Lost River & $10 / 09 / 91$ & 4.6 & 4.5 & .12 & \\
\hline Birch Creek & $4 / 05 / 90$ & 4.6 & 4.7 & .12 & \\
\hline Cerro Grande & $10 / 18 / 90$ & 22 & 21 & .58 & \\
\hline CFA-2 & $7 / 25 / 91$ & 91 & 91 & .00 & \\
\hline \multirow[t]{2}{*}{ CPP 1} & $11 / 06 / 89$ & 14 & 15 & .74 & \\
\hline & $10 / 31 / 90$ & 17 & 18 & .66 & \\
\hline \multirow[t]{3}{*}{ CPP 2} & $1 / 31 / 89$ & ${ }^{\#} 18 \pm 2$ & ${ }^{\#} 18 \pm 2$ & .00 & \\
\hline & $7 / 26 / 89$ & $\# 16 \pm 2$ & $\# 15 \pm 2$ & .35 & \\
\hline & $4 / 29 / 92$ & 18 & 18 & .00 & \\
\hline CPP 4 & $7 / 23 / 90$ & 16 & 17 & .69 & \\
\hline \multirow[t]{2}{*}{ CWP-4 } & $4 / 25 / 89$ & $\# 15 \pm 2$ & ${ }^{\#} 16 \pm 2$ & .35 & \\
\hline & $4 / 17 / 91$ & 20 & 20 & .00 & \\
\hline CWP-5 & $10 / 14 / 93$ & 11 & 11 & .00 & \\
\hline \multirow[t]{3}{*}{ EBR I } & $4 / 28 / 89$ & ${ }^{\#} 7 \pm 2$ & ${ }^{\#} 7 \pm 2$ & .00 & \\
\hline & $4 / 19 / 90$ & 7.8 & 7.5 & .31 & \\
\hline & $4 / 08 / 93$ & 6.6 & 6.4 & .22 & \\
\hline \multirow[t]{2}{*}{ Fire Station 2} & $4 / 18 / 91$ & 15 & 19 & 2.70 & $\mathbf{N}$ \\
\hline & $10 / 08 / 92$ & 16 & 16 & .00 & \\
\hline MTR Test & $10 / 07 / 92$ & 16 & 16 & .00 & \\
\hline NRF-1 & 9/09/91 & 31 & 31 & .00 & \\
\hline \multirow[t]{3}{*}{ NRF-2 } & $3 / 21 / 90$ & 45 & 45 & .00 & \\
\hline & $3 / 05 / 91$ & 54 & 55 & .29 & \\
\hline & $9 / 15 / 93$ & 47 & 48 & .32 & \\
\hline \multirow[t]{2}{*}{ NRF-3 } & $6 / 17 / 91$ & 36 & 36 & .00 & \\
\hline & $12 / 03 / 92$ & 35 & 36 & .40 & \\
\hline \multirow[t]{2}{*}{ NRF-4 } & $2 / 07 / 91$ & 41 & 40 & .36 & \\
\hline & $4 / 07 / 93$ & 43 & 45 & .68 & \\
\hline NRF-6 & $3 / 10 / 92$ & 200 & 190 & .91 & \\
\hline NRF-7 & $1 / 08 / 92$ & 6.5 & 6.5 & .00 & \\
\hline OMRE & $4 / 28 / 89$ & 18 & 18 & .00 & \\
\hline PW-1 & $4 / 24 / 89$ & $250 \pm 30$ & $\#_{250 \pm 30}$ & .00 & \\
\hline
\end{tabular}


Table 12. Comparison of results of replicate pairs of samples from the Idaho National Engineering Laboratory analyzed for chloride by the National Water Quality Laboratory and the Radiological and Environmental Sciences Laboratory-continued

\begin{tabular}{|c|c|c|c|c|c|}
\hline Site identifier & Date sampled & $\begin{array}{l}\text { Chloride } \\
\text { (mg/L) }\end{array}$ & $\begin{array}{c}\text { Chloride QA } \\
\text { (mg/L) }\end{array}$ & Z-value & Remark \\
\hline \multirow[t]{2}{*}{ PW-1 - cont. } & $10 / 27 / 89$ & ${ }^{\#} 260 \pm 30$ & $\# 250 \pm 30$ & 0.24 & \\
\hline & $7 / 03 / 90$ & 310 & 310 & .00 & \\
\hline \multirow[t]{2}{*}{ PW-2 } & $1 / 08 / 91$ & 260 & 260 & .00 & \\
\hline & $10 / 25 / 93$ & 290 & 320 & 1.77 & \\
\hline PW-3 & $3 / 30 / 90$ & 230 & 230 & .00 & \\
\hline \multirow[t]{4}{*}{ PW-4 } & $2 / 02 / 90$ & 250 & 250 & .00 & \\
\hline & $10 / 17 / 90$ & 300 & 300 & .00 & \\
\hline & $4 / 29 / 91$ & 280 & 280 & .00 & \\
\hline & $10 / 22 / 92$ & 290 & 290 & .00 & \\
\hline PW-5 & $10 / 17 / 91$ & 260 & 260 & .00 & \\
\hline \multirow[t]{2}{*}{ PW-8 } & $4 / 05 / 91$ & 22 & 22 & .00 & \\
\hline & $7 / 17 / 93$ & 12 & 11 & .84 & \\
\hline \multirow[t]{2}{*}{ PW-9 } & $2 / 04 / 93$ & 27 & 26 & .50 & \\
\hline & $4 / 06 / 93$ & 25 & 25 & .00 & \\
\hline \multirow[t]{2}{*}{ P\&W2 } & $4 / 18 / 89$ & $\# 18 \pm 2$ & $\# 17 \pm 2$ & .35 & \\
\hline & $3 / 14 / 90$ & 25 & 26 & .52 & \\
\hline RWMC Prod. & $10 / 30 / 90$ & 13 & 16 & 2.23 & $\mathbf{N}$ \\
\hline Site 9 & $9 / 27 / 91$ & 12 & 14 & 1.58 & \\
\hline \multirow[t]{2}{*}{ Site 14} & $10 / 18 / 91$ & 9.3 & 9.3 & .00 & \\
\hline & $11 / 04 / 93$ & 8.5 & 8.5 & .00 & \\
\hline \multirow[t]{2}{*}{ Site 19} & $10 / 01 / 90$ & 15 & 14 & .74 & \\
\hline & $4 / 07 / 92$ & 15 & 13 & 1.52 & \\
\hline SPERT-1 & $4 / 28 / 89$ & $\# 28 \pm 3$ & $\# 28 \pm 3$ & .00 & \\
\hline \multirow[t]{2}{*}{ TRA Disp. } & $1 / 18 / 90$ & 11 & 11 & .00 & \\
\hline & $10 / 11 / 90$ & 10 & 13 & 2.53 & $\mathbf{N}$ \\
\hline \multirow[t]{3}{*}{ TRA 3} & $4 / 27 / 89$ & ${ }^{\#} 12 \pm 2$ & ${ }^{\#} 12 \pm 2$ & .00 & \\
\hline & $4 / 10 / 92$ & 12 & 15 & 2.32 & $\mathbf{N}$ \\
\hline & $11 / 02 / 92$ & 11 & 11 & .00 & \\
\hline \multirow[t]{4}{*}{ TRA 4} & $11 / 13 / 89$ & 11 & 11 & .00 & \\
\hline & $4 / 25 / 91$ & 9.0 & 11 & 1.81 & \\
\hline & $10 / 30 / 91$ & 11 & 14 & 2.42 & $\mathbf{N}$ \\
\hline & $4 / 05 / 93$ & 10 & 10 & .00 & \\
\hline \multirow[t]{2}{*}{ WSINEL1 } & $12 / 07 / 90$ & 110 & 110 & .00 & \\
\hline & $12 / 03 / 91$ & 110 & 100 & 1.61 & \\
\hline USGS 1 & $7 / 20 / 92$ & 12 & 11 & .84 & \\
\hline USGS 8 & $4 / 03 / 91$ & 10 & 9.8 & .18 & \\
\hline USGS 11 & $10 / 08 / 91$ & 16 & 16 & .00 & \\
\hline USGS 12 & $6 / 15 / 90$ & 31 & 30 & .45 & \\
\hline
\end{tabular}


Table 12. Comparison of results of replicate pairs of samples from the Idaho National Engineering Laboratory analyzed for chloride by the National Water Quality Laboratory and the Radiological and Environmental Sciences Laboratory-continued

\begin{tabular}{|c|c|c|c|c|c|}
\hline Site identifier & Date sampled & $\begin{array}{l}\text { Chloride } \\
\text { (mg/L) }\end{array}$ & $\begin{array}{l}\text { Chloride QA } \\
\text { (mg/L) }\end{array}$ & $Z$-value & Remark \\
\hline \multirow[t]{2}{*}{ USGS 12 -cont. } & $9 / 06 / 91$ & 29 & 30 & 0.46 & \\
\hline & $11 / 05 / 93$ & 37 & 33 & 1.63 & \\
\hline \multirow[t]{2}{*}{ USGS 14} & $10 / 01 / 92$ & 22 & 22 & .00 & \\
\hline & $4 / 16 / 93$ & 20 & 20 & .00 & \\
\hline \multirow[t]{2}{*}{ USGS 15} & $8 / 06 / 90$ & 31 & 31 & .00 & \\
\hline & $3 / 12 / 92$ & 8.1 & 8.1 & .00 & \\
\hline \multirow[t]{2}{*}{ USGS 17} & $3 / 13 / 91$ & 7.1 & 6.9 & .21 & \\
\hline & $6 / 11 / 93$ & 5.9 & 5.9 & .00 & \\
\hline \multirow[t]{2}{*}{ USGS 19} & $10 / 12 / 90$ & 13 & 12 & .81 & \\
\hline & $10 / 01 / 92$ & 13 & 14 & .77 & \\
\hline USGS 20 & $4 / 08 / 91$ & 24 & 25 & .53 & \\
\hline \multirow[t]{2}{*}{ USGS 22} & $4 / 23 / 91$ & 72 & 65 & 1.65 & \\
\hline & $9 / 30 / 93$ & 60 & 60 & .00 & \\
\hline USGS 23 & $7 / 09 / 93$ & 9.2 & 9.8 & .56 & \\
\hline USGS 27 & $4 / 27 / 90$ & 67 & 63 & .99 & \\
\hline USGS 32 & $7 / 06 / 92$ & 45 & 44 & .34 & \\
\hline USGS 34 & $4 / 01 / 91$ & 18 & 18 & .00 & \\
\hline \multirow[t]{3}{*}{ USGS 35} & $10 / 07 / 91$ & 27 & 22 & 2.65 & $\mathbf{N}$ \\
\hline & $4 / 14 / 93$ & 25 & 24 & 6.53 & \\
\hline & $10 / 20 / 93$ & 21 & ${ }^{\otimes} 22$ & .58 & \\
\hline \multirow[t]{3}{*}{ USGS 37} & $1 / 02 / 90$ & 74 & 74 & .00 & \\
\hline & $4 / 18 / 90$ & 66 & 67 & .24 & \\
\hline & $10 / 21 / 93$ & 140 & 150 & 1.20 & \\
\hline \multirow[t]{2}{*}{ USGS 38} & $4 / 23 / 92$ & 140 & 150 & 1.20 & \\
\hline & $10 / 14 / 92$ & 170 & 160 & 1.06 & \\
\hline \multirow[t]{3}{*}{ USGS 40} & $10 / 18 / 89$ & 23 & 23 & .00 & \\
\hline & $10 / 18 / 89$ & 27 & 23 & 2.09 & $\mathbf{N}$ \\
\hline & $4 / 25 / 91$ & 35 & 30 & 2.16 & $\mathbf{N}$ \\
\hline USGS 43 & $4 / 13 / 90$ & 27 & 27 & .00 & \\
\hline \multirow[t]{2}{*}{ USGS 44} & $10 / 26 / 90$ & 20 & 20 & .00 & \\
\hline & $11 / 01 / 93$ & 20 & 19 & .62 & \\
\hline USGS 45 & $4 / 20 / 92$ & 23 & 19 & 2.36 & $\mathbf{N}$ \\
\hline USGS 46 & $10 / 09 / 91$ & 24 & 27 & 1.55 & \\
\hline USGS 47 & $4 / 10 / 91$ & 28 & 26 & .99 & \\
\hline USGS 52 & $4 / 03 / 90$ & 25 & 25 & .00 & \\
\hline \multirow[t]{3}{*}{ USGS 54} & $7 / 07 / 89$ & $\#_{21 \pm 2}$ & $\#_{22 \pm 2}$ & .35 & \\
\hline & $11 / 03 / 89$ & 19 & 19 & .00 & \\
\hline & $1 / 14 / 91$ & 29 & 25 & 1.98 & $\mathbf{N}$ \\
\hline
\end{tabular}


Table 12. Comparison of results of replicate pairs of samples from the Idaho National Engineering Laboratory analyzed for chloride by the National Water Quality Laboratory and the Radiological and Environmental Sciences Laboratory-continued

\begin{tabular}{|c|c|c|c|c|c|}
\hline Site identifier & Date sampled & $\begin{array}{l}\text { Chloride } \\
\text { (mg/L) }\end{array}$ & $\begin{array}{c}\text { Chloride QA } \\
(\mathrm{mg} / \mathrm{L})\end{array}$ & $\mathrm{Z}$-value & Remark \\
\hline \multirow[t]{4}{*}{ USGS 54 - cont. } & $10 / 16 / 92$ & 9.4 & 9.2 & 0.19 & \\
\hline & $4 / 19 / 93$ & 12 & 12 & .00 & \\
\hline & $7 / 22 / 93$ & 12 & $\otimes_{12}$ & .00 & \\
\hline & $10 / 13 / 93$ & 11 & 12 & .84 & \\
\hline USGS 56 & $11 / 15 / 89$ & 12 & 12 & .00 & \\
\hline \multirow[t]{4}{*}{ USGS 57} & $12 / 22 / 89$ & 67 & 67. & .00 & \\
\hline & $6 / 28 / 90$ & 78 & 85 & 1.41 & \\
\hline & $10 / 29 / 90$ & 85 & 88 & .58 & \\
\hline & $7 / 21 / 93$ & 180 & ${ }^{\otimes} 160$ & 2.06 & $\mathbf{N}$ \\
\hline \multirow[t]{2}{*}{ USGS 58} & 4/03/91 & 12 & 11 & .84 & \\
\hline & $10 / 21 / 93$ & 11 & 11 & .00 & \\
\hline \multirow[t]{4}{*}{ USGS 59} & $4 / 17 / 89$ & $\#_{23} \pm 2$ & $\#_{29 \pm 3}$ & 1.66 & \\
\hline & $4 / 28 / 92$ & 56 & 56 & .00 & \\
\hline & $4 / 22 / 93$ & 160 & 160 & .00 & \\
\hline & $10 / 25 / 93$ & 44 & 43 & .34 & \\
\hline USGS 60 & $1 / 10 / 92$ & 110 & 17 & 19.80 & $\mathbf{N}$ \\
\hline USGS 61 & $9 / 27 / 90$ & 19 & 17 & 1.30 & \\
\hline \multirow[t]{2}{*}{ USGS 62} & $4 / 09 / 92$ & 23 & 23 & .00 & \\
\hline & $10 / 13 / 92$ & 14 & 14 & .00 & \\
\hline USGS 63 & $4 / 10 / 90$ & 22 & 22 & .00 & \\
\hline USGS 65 & $10 / 15 / 91$ & 22 & 22 & .00 & \\
\hline USGS 66 & $4 / 29 / 92$ & 23 & 24 & .55 & \\
\hline \multirow[t]{3}{*}{ USGS 68} & $4 / 27 / 89$ & $\# 33 \pm 3$ & $\#_{33 \pm 3}$ & .00 & \\
\hline & $7 / 02 / 91$ & 47 & 44 & 1.00 & \\
\hline & $1 / 17 / 92$ & 52 & 58 & 1.70 & \\
\hline USGS 69 & $10 / 24 / 91$ & 22 & 22 & .00 & \\
\hline \multirow[t]{2}{*}{ USGS 71} & $4 / 22 / 91$ & 20 & 21 & .60 & \\
\hline & $10 / 12 / 93$ & 19 & 18 & .64 & \\
\hline USGS 72 & $10 / 28 / 93$ & 16 & 16 & .00 & \\
\hline \multirow[t]{4}{*}{ USGS 76} & $1 / 05 / 90$ & 11 & 11 & .00 & \\
\hline & $10 / 17 / 90$ & 13 & 13 & .00 & \\
\hline & $4 / 26 / 93$ & 12 & 12 & .00 & \\
\hline & $10 / 21 / 93$ & 11 & $\otimes_{11}$ & .00 & \\
\hline USGS 77 & $10 / 09 / 92$ & 120 & 120 & .00 & \\
\hline \multirow[t]{2}{*}{ USGS 82} & $7 / 07 / 93$ & 16 & 16 & .00 & \\
\hline & $4 / 15 / 92$ & 20 & 20 & .00 & \\
\hline \multirow[t]{2}{*}{ USGS 83} & $10 / 11 / 90$ & 13 & 12 & .81 & \\
\hline & $4 / 06 / 92$ & 16 & 17 & .69 & \\
\hline
\end{tabular}


Table 12. Comparison of results of replicate pairs of samples from the Idaho National Engineering Laboratory analyzed for chloride by the National Water Quality Laboratory and the Radiological and Environmental Sciences Laboratory-continued

\begin{tabular}{|c|c|c|c|c|c|}
\hline Site identifier & Date sampled & $\begin{array}{l}\text { Chloride } \\
\text { (mg/L) }\end{array}$ & $\begin{array}{l}\text { Chloride QA } \\
\text { (mg/L) }\end{array}$ & Z-value & Remark \\
\hline USGS 84 & $10 / 09 / 92$ & 12 & 12 & 0.00 & \\
\hline \multirow[t]{2}{*}{ USGS 85} & $4 / 26 / 90$ & 53 & 53 & .00 & \\
\hline & $4 / 19 / 93$ & 67 & 63 & .99 & \\
\hline \multirow[t]{2}{*}{ USGS 86} & $4 / 21 / 89$ & $\# 23 \pm 2$ & $\# 23 \pm 2$ & .00 & \\
\hline & $10 / 13 / 93$ & 19 & 20 & .62 & \\
\hline USGS 87 & $4 / 21 / 92$ & 16 & 21 & 3.19 & $\mathbf{N}$ \\
\hline \multirow[t]{3}{*}{ USGS 88} & $7 / 12 / 89$ & ${ }^{\#} 100 \pm 10$ & ${ }^{\#} 100 \pm 10$ & .00 & \\
\hline & $7 / 16 / 91$ & 85 & 87 & .39 & \\
\hline & $1 / 20 / 93$ & 89 & 91 & .37 & \\
\hline \multirow[t]{3}{*}{ USGS 89} & $1 / 04 / 89$ & $\# 46 \pm 5$ & $\# 46 \pm 5$ & .00 & \\
\hline & $10 / 16 / 91$ & 42 & 42 & .00 & \\
\hline & $1 / 17 / 92$ & 42 & 42 & .00 & \\
\hline \multirow[t]{5}{*}{ USGS 90} & $1 / 18 / 89$ & $\#_{20 \pm 2}$ & ${ }^{\#} 18 \pm 2$ & .71 & \\
\hline & $1 / 23 / 90$ & 13 & 13 & .00 & \\
\hline & $1 / 16 / 92$ & 13 & 13 & .00 & \\
\hline & $4 / 20 / 92$ & 17 & 16 & .69 & \\
\hline & $10 / 04 / 93$ & 12 & 13 & .81 & \\
\hline \multirow[t]{4}{*}{ USGS 97} & $6 / 07 / 90$ & 31 & 34 & 1.30 & \\
\hline & $12 / 07 / 90$ & 32 & 33 & .43 & \\
\hline & $6 / 07 / 91$ & 29 & 28 & .48 & \\
\hline & $11 / 04 / 93$ & 32 & 32 & .00 & \\
\hline \multirow[t]{2}{*}{ USGS 98} & $7 / 30 / 90$ & 18 & 18 & .00 & \\
\hline & $9 / 21 / 92$ & 17 & 18 & .66 & \\
\hline \multirow[t]{2}{*}{ USGS 99} & $10 / 03 / 90$ & 19 & 19 & .00 & \\
\hline & $6 / 16 / 92$ & 20 & 20 & .00 & \\
\hline \multirow[t]{3}{*}{ USGS 100} & $1 / 07 / 91$ & 19 & 19 & .00 & \\
\hline & $10 / 05 / 92$ & 18 & 18 & .00 & \\
\hline & $4 / 23 / 93$ & 16 & 17 & .69 & \\
\hline \multirow[t]{2}{*}{ USGS 102} & $12 / 10 / 90$ & 28 & 30 & .94 & \\
\hline & $12 / 09 / 92$ & 31 & 31 & .00 & \\
\hline USGS 103 & $7 / 16 / 93$ & 15 & 15 & .00 & \\
\hline \multirow[t]{4}{*}{ USGS 104} & $10 / 16 / 89$ & 10 & 11 & .88 & \\
\hline & $7 / 09 / 90$ & 13 & 12 & .81 & \\
\hline & $1 / 10 / 91$ & 15 & 15 & .00 & \\
\hline & $9 / 29 / 92$ & 12 & 12 & .00 & \\
\hline USGS 105 & $10 / 25 / 89$ & 13 & 13 & .00 & \\
\hline USGS 106 & $4 / 02 / 90$ & 12 & 15 & 2.32 & $\mathbf{N}$ \\
\hline USGS 106 & $4 / 02 / 92$ & 15 & 15 & .00 & \\
\hline
\end{tabular}


Table 12. Comparison of results of replicate pairs of samples from the Idaho National Engineering Laboratory analyzed for chloride by the National Water Quality Laboratory and the Radiological and Environmental Sciences Laboratory-continued

\begin{tabular}{|c|c|c|c|c|c|}
\hline Site identifier & Date sampled & $\begin{array}{c}\text { Chloride } \\
(\mathrm{mg} / \mathrm{L})\end{array}$ & $\begin{array}{c}\text { Chloride QA } \\
(\mathrm{mg} / \mathrm{L})\end{array}$ & $Z$-value & Remark \\
\hline \multirow[t]{2}{*}{ USGS 107} & $4 / 22 / 91$ & 23 & 21 & 1.14 & \\
\hline & $4 / 21 / 93$ & 20 & 20 & .00 & \\
\hline USGS 109 & $10 / 01 / 93$ & 13 & 14 & .77 & \\
\hline \multirow[t]{2}{*}{ USGS 110} & $4 / 12 / 89$ & $\# 18 \pm 2$ & ${ }^{\#} 18 \pm 2$ & .00 & \\
\hline & $10 / 11 / 89$ & $\#_{22} \pm 2$ & $\#_{21 \pm 2}$ & .62 & \\
\hline USGS 111 & $3 / 20 / 90$ & 110 & 110 & .00 & \\
\hline USGS 113 & $7 / 15 / 91$ & 180 & 200 & 1.85 & \\
\hline \multirow[t]{3}{*}{ USGS 114} & $10 / 05 / 89$ & 81 & 81 & .00 & \\
\hline & $9 / 24 / 90$ & 81 & 81 & .00 & \\
\hline & $10 / 21 / 91$ & 87 & 88 & .19 & \\
\hline USGS 115 & $7 / 16 / 93$ & 33 & 32 & .43 & \\
\hline \multirow[t]{2}{*}{ USGS 116} & $4 / 06 / 89$ & $\# 71 \pm 2$ & $\# 70 \pm 2$ & .10 & \\
\hline & $10 / 05 / 89$ & 68 & 68 & .00 & \\
\hline USGS 117 & $4 / 18 / 91$ & 15 & 17 & 1.40 & \\
\hline \multirow[t]{4}{*}{ USGS 119} & $4 / 03 / 89$ & $\# 10 \pm 2$ & ${ }^{\#} 10 \pm 2$ & .00 & \\
\hline & $6 / 28 / 89$ & ${ }^{\#} 12 \pm 2$ & ${ }^{\#} 12 \pm 2$ & .00 & \\
\hline & $4 / 09 / 90$ & 8.8 & 8.8 & .00 & \\
\hline & $7 / 09 / 92$ & 9.1 & 1.0 & 9.37 & $\mathbf{N}$ \\
\hline USGS 120 & $7 / 19 / 90$ & 27 & 26 & .53 & \\
\hline \multirow[t]{2}{*}{ USGS 122} & $10 / 15 / 91$ & 71 & 74 & .67 & \\
\hline & $4 / 15 / 92$ & 83 & 85 & .39 & \\
\hline
\end{tabular}


Table 13. Comparison of results of replicate pairs of samples from the Idaho National Engineering Laboratory analyzed for fluoride by the National Water Quality Laboratory

[Site identifier: see figures 1-3 for location of sites. QA: quality-assurance replicate sample. Z-value: see section on Statistical Comparisons of Replicate Pairs of Samples for explanation. Abbreviations: $m g / L$, milligram per liter; N, the analytical results are not in statistical agreement. Symbol: $<$, the result was less than the indicated reporting level]

\begin{tabular}{|c|c|c|c|c|c|}
\hline Site identifier & Date sampled & $\begin{array}{c}\text { Fluoride } \\
(\mathrm{mg} / \mathrm{L})\end{array}$ & $\begin{array}{l}\text { Fluoride QA } \\
(\mathrm{mg} / \mathrm{L})\end{array}$ & Z-value & Remark \\
\hline Cerro Grande & $10 / 18 / 90$ & 0.3 & 0.3 & 0.00 & \\
\hline CPP 1 & $10 / 31 / 90$ & .3 & .3 & .00 & \\
\hline$N_{R F} 1$ & $9 / 09 / 91$ & .2 & .2 & .00 & \\
\hline \multirow[t]{3}{*}{ NRF-2 } & $3 / 21 / 90$ & $<.1$ & $<.1$ & 0 & \\
\hline & $3 / 05 / 91$ & .2 & .1 & .94 & \\
\hline & $9 / 15 / 93$ & .2 & .2 & .00 & \\
\hline \multirow[t]{2}{*}{ NRF-3 } & $6 / 17 / 91$ & .2 & .2 & .00 & \\
\hline & $12 / 03 / 92$ & .1 & .1 & .00 & \\
\hline \multirow[t]{2}{*}{ NRF-4 } & $2 / 07 / 91$ & .1 & .2 & .94 & \\
\hline & $4 / 07 / 93$ & .2 & .2 & .00 & \\
\hline NRF-6 & $3 / 10 / 92$ & .2 & .2 & .00 & \\
\hline NRF-7 & $1 / 08 / 92$ & .3 & .3 & .00 & \\
\hline PW-2 & $1 / 08 / 91$ & .4 & .3 & .94 & \\
\hline PW-4 & $10 / 17 / 90$ & .2 & .2 & .00 & \\
\hline RWMC Prod. & $10 / 30 / 90$ & .2 & .3 & .94 & \\
\hline Site 19 & $10 / 01 / 90$ & .1 & .2 & .94 & \\
\hline TRA Disp. & $10 / 11 / 90$ & $<.1$ & $<.1$ & 0 & \\
\hline \multirow[t]{2}{*}{ WSINEL1 } & $12 / 07 / 90$ & .1 & .1 & .00 & \\
\hline & $12 / 03 / 91$ & .2 & .2 & .00 & \\
\hline \multirow[t]{3}{*}{ USGS 12} & $6 / 15 / 90$ & $<1$ & .1 & 0 & \\
\hline & $9 / 06 / 91$ & .2 & .2 & .00 & \\
\hline & $11 / 05 / 93$ & .2 & .2 & .00 & \\
\hline \multirow[t]{2}{*}{ USGS 15} & $8 / 06 / 90$ & .4 & .4 & .00 & \\
\hline & $3 / 12 / 92$ & .1 & .2 & .94 & \\
\hline \multirow[t]{2}{*}{ USGS 17} & $3 / 13 / 91$ & .2 & .2 & .00 & \\
\hline & $6 / 11 / 93$ & .2 & .2 & .00 & \\
\hline USGS 19 & $10 / 12 / 90$ & $<.1$ & $<.1$ & 0 & \\
\hline USGS 44 & $10 / 26 / 90$ & $<.1$ & $<.1$ & 0 & \\
\hline USGS 54 & $1 / 14 / 91$ & .4 & .3 & .94 & \\
\hline USGS 57 & $10 / 29 / 90$ & .4 & .4 & .00 & \\
\hline USGS 61 & $9 / 27 / 90$ & $<.1$ & .2 & .94 & \\
\hline USGS 76 & $10 / 17 / 90$ & $<.1$ & $<.1$ & 0 & \\
\hline USGS 83 & $10 / 11 / 90$ & .2 & .1 & .94 & \\
\hline \multirow[t]{2}{*}{ USGS 97} & $6 / 07 / 90$ & $<.1$ & .4 & 2.83 & $\mathrm{~N}$ \\
\hline & $12 / 07 / 90$ & .1 & .1 & .00 & \\
\hline
\end{tabular}


Table 13. Comparison of results of replicate pairs of samples from the Idaho National Engineering Laboratory analyzed for fluoride by the National Water Quality Laboratory - continued

\begin{tabular}{llcccc}
\hline Site identifier & Date sampled & $\begin{array}{c}\text { Fluoride } \\
(\mathrm{mg} / \mathrm{L})\end{array}$ & $\begin{array}{c}\text { Fluoride QA } \\
(\mathrm{mg} / \mathrm{L})\end{array}$ & Z-value & Remark \\
\hline USGS 97 - cont. & $6 / 07 / 91$ & .2 & .2 & 0.00 & \\
& $11 / 04 / 93$ & .2 & .2 & .00 & \\
USGS 98 & $7 / 30 / 90$ & .4 & .7 & 2.83 & $\mathrm{~N}$ \\
& $9 / 21 / 92$ & .2 & .3 & .94 & \\
USGS 99 & $10 / 03 / 90$ & $<.1$ & $<.1$ & 0 & .00 \\
& $6 / 16 / 92$ & .2 & .2 & .00 & .94 \\
USGS 100 & $1 / 07 / 91$ & .7 & .7 & .00 & \\
USGS 102 & $12 / 10 / 90$ & .2 & .1 & .00 \\
\hline
\end{tabular}


Table 14. Comparison of results of replicate pairs of samples from the Idaho National Engineering Laboratory analyzed for bromide by the National Water Quality Laboratory

[Site identifier: see figures 1-3 for location of sites; QA: quality-assurance replicate sample. Z-value: see section on Statistical Comparisons of Replicate Pairs of Samples for explanation. Abbreviations: $\mathrm{mg} / \mathrm{L}$, milligram per liter; $\mathrm{N}$, the analytical results are not in statistical agreement]

\begin{tabular}{|c|c|c|c|c|c|}
\hline Site identifier & Date sampled & $\begin{array}{c}\text { Bromide } \\
\text { (mg/L) }\end{array}$ & $\begin{array}{c}\text { Bromide QA } \\
(\mathrm{mg} / \mathrm{L})\end{array}$ & Z-value & Remark \\
\hline NRF-1 & $9 / 09 / 91$ & 0.07 & 0.08 & 0.63 & \\
\hline \multirow[t]{3}{*}{ NRF-2 } & $3 / 21 / 90$ & .07 & .06 & .72 & \\
\hline & $3 / 05 / 91$ & .06 & .07 & .72 & \\
\hline & $9 / 15 / 93$ & .07 & .07 & .00 & \\
\hline \multirow[t]{2}{*}{ NRF-3 } & $6 / 17 / 91$ & .07 & .07 & .00 & \\
\hline & $12 / 03 / 92$ & .08 & .07 & .63 & \\
\hline \multirow[t]{2}{*}{ NRF-4 } & $2 / 07 / 91$ & .06 & .07 & .72 & \\
\hline & $4 / 07 / 93$ & .09 & .09 & .00 & \\
\hline NRF-6 & $3 / 10 / 92$ & .08 & .08 & .00 & \\
\hline NRF-7 & $1 / 08 / 92$ & .02 & .03 & 1.85 & \\
\hline \multirow{2}{*}{ WSINEL1 } & $12 / 07 / 90$ & .29 & .29 & .00 & \\
\hline & $12 / 03 / 91$ & .31 & .31 & .00 & \\
\hline \multirow[t]{3}{*}{ USGS 12} & $6 / 15 / 90$ & .06 & .06 & .00 & \\
\hline & $9 / 06 / 91$ & .08 & .08 & .00 & \\
\hline & $11 / 05 / 93$ & .08 & .08 & .00 & \\
\hline \multirow[t]{2}{*}{ USGS 15} & $8 / 06 / 90$ & .07 & .07 & .00 & \\
\hline & $3 / 12 / 92$ & .02 & .01 & 2.98 & $\mathbf{N}$ \\
\hline \multirow[t]{2}{*}{ USGS 17} & $3 / 13 / 91$ & .02 & .02 & .00 & \\
\hline & $6 / 11 / 93$ & .03 & .03 & .00 & \\
\hline \multirow[t]{4}{*}{ USGS 97} & $6 / 07 / 90$ & .06 & .06 & .00 & \\
\hline & $12 / 07 / 90$ & .06 & .06 & .00 & \\
\hline & $6 / 07 / 91$ & .08 & .08 & .00 & \\
\hline & $11 / 04 / 93$ & .07 & .08 & .63 & \\
\hline \multirow[t]{2}{*}{ USGS 98} & $7 / 30 / 90$ & .04 & .04 & .00 & \\
\hline & $9 / 21 / 92$ & .05 & .05 & .00 & \\
\hline \multirow[t]{2}{*}{ USGS 99} & $10 / 03 / 90$ & .05 & .05 & .00 & \\
\hline & $6 / 16 / 92$ & .05 & .05 & .00 & \\
\hline \multirow[t]{2}{*}{ USGS 102} & $12 / 10 / 90$ & .06 & .05 & .85 & \\
\hline & $12 / 09 / 92$ & .07 & .07 & .00 & \\
\hline
\end{tabular}


Table 15. Comparison of results of replicate pairs of samples from the Idaho National Engineering Laboratory analyzed for dissolved nitrite, as nitrogen, by the National Water Quality Laboratory

[Site identifier: see figures 1-3 for location of sites. QA: quality-assurance replicate sample. Z-value: see section on Statistical Comparisons of Replicate Pairs of Samples for explanation. Abbreviations: mg/L, milligram per liter; U, statistical agreement of the analytical result is uncertain. Symbols: <, the result was less than the indicated reporting level; ${ }^{\otimes}$, the QA sample was collected within 24 hours]

\begin{tabular}{|c|c|c|c|c|c|}
\hline Site identifier & Date sampled & $\begin{array}{l}\text { Dissolved } \\
\text { nitrite, as } \\
\text { nitrogen } \\
(\mathrm{mg} / \mathrm{L})\end{array}$ & $\begin{array}{c}\text { Dissolved } \\
\text { nitrite, as } \\
\text { nitrogen, QA } \\
(\mathrm{mg} / \mathrm{L})\end{array}$ & $Z$-value & Remarks \\
\hline Area II & $7 / 14 / 93$ & $<0.01$ & $<0.01$ & 0 & \\
\hline \multirow[t]{2}{*}{ CPP 1} & $11 / 06 / 89$ & $<.01$ & $<.01$ & 0 & \\
\hline & $10 / 31 / 90$ & $<.01$ & $<.01$ & 0 & \\
\hline Fire Station 2 & $10 / 08 / 92$ & $<.01$ & $<.01$ & 0 & \\
\hline MTR Test & $10 / 07 / 92$ & $<.01$ & $<.01$ & 0 & \\
\hline NRF-1 & $9 / 09 / 91$ & $<.01$ & .01 & & $\mathrm{U}$ \\
\hline \multirow[t]{3}{*}{ NRF-2 } & $3 / 21 / 90$ & $<.01$ & $<.01$ & 0 & \\
\hline & $3 / 05 / 91$ & $<.01$ & $<.01$ & 0 & \\
\hline & $9 / 15 / 93$ & $<.01$ & $<.01$ & 0 & \\
\hline \multirow[t]{2}{*}{ NRF-3 } & $6 / 17 / 93$ & $<.01$ & $<.01$ & 0 & \\
\hline & $12 / 03 / 92$ & $<.01$ & $<.01$ & 0 & \\
\hline \multirow[t]{2}{*}{ NRF-4 } & $2 / 07 / 91$ & $<.01$ & $<.01$ & 0 & \\
\hline & 4/07/93 & $<.01$ & $<.01$ & 0 & \\
\hline NRF-6 & $3 / 10 / 92$ & $<.01$ & $<.01$ & 0 & \\
\hline NRF-7 & $1 / 08 / 92$ & $<.01$ & $<.01$ & 0 & \\
\hline PW-1 & $10 / 27 / 89$ & $<.01$ & $<.01$ & 0 & \\
\hline RWMC Prod. & $10 / 30 / 90$ & $<.01$ & $<.01$ & 0 & \\
\hline Site 9 & $9 / 27 / 91$ & $<.01$ & $<.01$ & 0 & \\
\hline Site 14 & $11 / 04 / 93$ & $<.01$ & $<.01$ & 0 & \\
\hline TRA Disp. & $10 / 11 / 90$ & $<.01$ & $<.01$ & 0 & \\
\hline \multirow[t]{2}{*}{ WSINEL1 } & $12 / 07 / 90$ & $<.01$ & $<.01$ & 0 & \\
\hline & $12 / 03 / 91$ & $<.01$ & $<.01$ & 0 & \\
\hline USGS 1 & $7 / 20 / 92$ & $<.01$ & $<.01$ & 0 & \\
\hline \multirow[t]{2}{*}{ USGS 12} & $9 / 06 / 91$ & $<.01$ & $<.01$ & 0 & \\
\hline & $11 / 05 / 93$ & $<.01$ & $<.01$ & 0 & \\
\hline \multirow[t]{2}{*}{ USGS 15} & $8 / 06 / 90$ & $<.01$ & $<.01$ & 0 & \\
\hline & $3 / 12 / 92$ & $<.01$ & $<.01$ & 0 & \\
\hline \multirow[t]{2}{*}{ USGS 17} & $3 / 13 / 91$ & .02 & .02 & .00 & \\
\hline & $6 / 11 / 93$ & $<.01$ & $<.01$ & 0 & \\
\hline USGS 19 & $10 / 01 / 92$ & $<.01$ & $<.01$ & 0 & \\
\hline USGS 23 & $7 / 09 / 93$ & $<.01$ & $<.01$ & 0 & \\
\hline USGS 32 & $7 / 06 / 92$ & $<.01$ & $<.01$ & 0 & \\
\hline USGS 35 & $10 / 07 / 91$ & .01 & .01 & .00 & \\
\hline
\end{tabular}


Table 15. Comparison of results of replicate pairs of samples from the Idaho National Engineering Laboratory analyzed for dissolved nitrite, as nitrogen, by the National Water Quality Laboratory-continued

\begin{tabular}{|c|c|c|c|c|c|}
\hline Site identifier & Date sampled & $\begin{array}{c}\text { Dissolved } \\
\text { nitrite, as } \\
\text { nitrogen } \\
(\mathrm{mg} / \mathrm{L})\end{array}$ & $\begin{array}{c}\text { Dissolved } \\
\text { nitrite, as } \\
\text { nitrogen, QA } \\
(\mathrm{mg} / \mathrm{L})\end{array}$ & $\mathrm{Z}$-value & Remarks \\
\hline & $10 / 20 / 93$ & $<.01$ & ${ }^{8}<.01$ & 0 & \\
\hline USGS 37 & $10 / 21 / 93$ & $<.01$ & $<.01$ & 0 & \\
\hline USGS 38 & $10 / 14 / 92$ & $<.01$ & $<.01$ & 0 & \\
\hline USGS 40 & $10 / 18 / 89$ & $<.01$ & $<.01$ & 0 & \\
\hline \multirow[t]{2}{*}{ USGS 44} & $10 / 26 / 90$ & $<.01$ & $<.01$ & 0 & \\
\hline & $11 / 01 / 93$ & $<.01$ & $<.01$ & 0 & \\
\hline USGS 46 & $10 / 09 / 91$ & .01 & .01 & .00 & \\
\hline \multirow[t]{2}{*}{ USGS 57} & $12 / 22 / 89$ & $<.01$ & $<.01$ & 0 & \\
\hline & $10 / 29 / 90$ & $<.01$ & $<.01$ & 0 & \\
\hline USGS 58 & $10 / 21 / 93$ & $<.01$ & $<.01$ & 0 & \\
\hline USGS 59 & $10 / 25 / 93$ & $<.01$ & $<.01$ & 0 & \\
\hline USGS 65 & $10 / 15 / 91$ & $<.01$ & $<.01$ & 0 & \\
\hline \multirow[t]{2}{*}{ USGS 76} & $10 / 17 / 90$ & $<.01$ & $<.01$ & 0 & \\
\hline & $10 / 21 / 93$ & $<.01$ & ${ }^{\otimes}<.01$ & 0 & \\
\hline USGS 77 & $10 / 09 / 92$ & $<.01$ & $<.01$ & 0 & \\
\hline USGS 83 & $10 / 11 / 90$ & $<.01$ & $<.01$ & 0 & \\
\hline USGS 89 & $10 / 16 / 91$ & $<.01$ & $<.01$ & 0 & \\
\hline USGS 90 & $10 / 04 / 93$ & $<.01$ & $<.01$ & 0 & \\
\hline USGS 97 & $6 / 07 / 90$ & $<.01$ & $<.01$ & 0 & \\
\hline \multirow[t]{2}{*}{ USGS 102} & $12 / 10 / 90$ & $<.01$ & $<.01$ & 0 & \\
\hline & $12 / 09 / 92$ & .02 & .02 & .00 & \\
\hline \multirow[t]{2}{*}{ USGS 104} & $10 / 16 / 89$ & $<.01$ & $<.01$ & 0 & \\
\hline & $9 / 29 / 92$ & $<.01$ & $<.01$ & 0 & \\
\hline \multirow[t]{3}{*}{ USGS 114} & $10 / 05 / 89$ & $<.01$ & $<.01$ & 0 & \\
\hline & $9 / 24 / 90$ & $<.01$ & $<.01$ & 0 & \\
\hline & $10 / 21 / 91$ & $<.01$ & $<.01$ & 0 & \\
\hline USGS 116 & $10 / 05 / 89$ & $<.01$ & .01 & & $\mathrm{U}$ \\
\hline USGS 122 & $10 / 15 / 91$ & $<.01$ & $<.01$ & 0 & \\
\hline
\end{tabular}


Table 16. Comparison of results of replicate pairs of samples from the Idaho National Engineering Laboratory analyzed for dissolved nitrite plus nitrate, as nitrogen, by the National Water Quality Laboratory

[Site identifier: see figures 1-3 for location of sites. QA: quality-assurance replicate sample. Z-value: see section on Statistical Comparisons of Replicate Pairs of Samples for explanation. Abbreviations: mg/L, milligram per liter; N, the analytical results are not in statistical agreement. Symbol: ${ }^{\otimes}$, the QA sample was collected within 24 hours]

\begin{tabular}{|c|c|c|c|c|c|}
\hline Site identifier & Date sampled & $\begin{array}{c}\text { Dissolved } \\
\text { nitrite plus } \\
\text { nitrate, as } \\
\text { nitrogen } \\
(\mathrm{mg} / \mathrm{L})\end{array}$ & $\begin{array}{c}\text { Dissolved } \\
\text { nitrite plus } \\
\text { nitrate, as } \\
\text { nitrogen, QA } \\
(\mathrm{mg} / \mathrm{L})\end{array}$ & $Z$-value & Remark \\
\hline Area II & $7 / 14 / 93$ & 1.1 & 1.1 & 0.00 & \\
\hline \multirow[t]{2}{*}{ CPP 1} & $11 / 06 / 89$ & .83 & .81 & .17 & \\
\hline & $10 / 31 / 90$ & .9 & 1.0 & .77 & \\
\hline Fire Station 2 & $10 / 08 / 92$ & 1.1 & 1.2 & .70 & \\
\hline MTR Test & $10 / 07 / 92$ & 1.3 & 1.3 & .00 & \\
\hline NRF-1 & $9 / 09 / 91$ & 1.7 & 1.6 & .56 & \\
\hline \multirow[t]{3}{*}{ NRF-2 } & $3 / 21 / 90$ & 1.9 & 1.8 & .51 & \\
\hline & $3 / 05 / 91$ & 1.9 & 1.9 & .00 & \\
\hline & $9 / 15 / 93$ & 2.0 & 2.0 & .00 & \\
\hline \multirow[t]{2}{*}{ NRF-3 } & $6 / 17 / 91$ & 1.8 & 1.8 & .00 & \\
\hline & $12 / 03 / 92$ & 1.9 & 1.9 & .00 & \\
\hline \multirow[t]{2}{*}{ NRF-4 } & 2/07/91 & 1.8 & 1.8 & .00 & \\
\hline & 4/07/93 & 2.0 & 2.0 & .00 & \\
\hline NRF-6 & $3 / 10 / 92$ & 1.7 & 1.7 & .00 & \\
\hline NRF-7 & $1 / 08 / 92$ & .39 & .38 & .11 & \\
\hline PW-1 & $10 / 27 / 89$ & 1.9 & 1.9 & .00 & \\
\hline RWMC Prod. & $10 / 30 / 90$ & .70 & .70 & .00 & \\
\hline Site 9 & $9 / 27 / 91$ & .64 & .64 & .00 & \\
\hline Site 14 & $11 / 04 / 93$ & .59 & .64 & .48 & \\
\hline TRA Disp. & $10 / 11 / 90$ & 1.1 & 1.2 & .70 & \\
\hline \multirow[t]{2}{*}{ WSINEL1 } & $12 / 07 / 90$ & 5.1 & 5.0 & .24 & \\
\hline & $12 / 03 / 91$ & 5.1 & 5.4 & .68 & \\
\hline USGS 1 & $7 / 20 / 92$ & .86 & .84 & .16 & \\
\hline \multirow[t]{2}{*}{ USGS 12} & $9 / 06 / 91$ & 1.8 & 1.7 & .53 & \\
\hline & $11 / 05 / 93$ & 2.0 & 2.0 & .00 & \\
\hline \multirow[t]{2}{*}{ USGS 15} & $8 / 06 / 90$ & 1.8 & 16 & 16.33 & $\mathbf{N}$ \\
\hline & $3 / 12 / 92$ & .30 & .34 & .48 & \\
\hline \multirow[t]{2}{*}{ USGS 17} & $3 / 13 / 91$ & .34 & .31 & .36 & \\
\hline & $6 / 11 / 93$ & .35 & .34 & .12 & \\
\hline USGS 19 & $10 / 01 / 92$ & 1.1 & 1.1 & .00 & \\
\hline USGS 23 & $7 / 09 / 93$ & .69 & .66 & .27 & \\
\hline USGS 32 & $7 / 06 / 92$ & 1.3 & 1.3 & .00 & \\
\hline USGS 35 & $10 / 07 / 91$ & 1.4 & 1.5 & .60 & \\
\hline
\end{tabular}


Table 16. Comparison of results of replicate pairs of samples from the Idaho National Engineering Laboratory analyzed for dissolved nitrite plus nitrate, as nitrogen, by the National Water Quality Laboratory -continued

\begin{tabular}{|c|c|c|c|c|c|}
\hline Site identifier & Date sampled & $\begin{array}{c}\text { Dissolved } \\
\text { nitrite plus } \\
\text { nitrate, as } \\
\text { nitrogen } \\
(\mathrm{mg} / \mathrm{L})\end{array}$ & $\begin{array}{c}\text { Dissolved } \\
\text { nitrite plus } \\
\text { nitrate, as } \\
\text { nitrogen, QA } \\
(\mathrm{mg} / \mathrm{L})\end{array}$ & $\mathrm{Z}$-value & Remark \\
\hline USGS 35 - cont. & $10 / 20 / 93$ & 1.5 & ${ }^{\otimes} 1.2$ & 1.89 & \\
\hline USGS 37 & $10 / 21 / 93$ & 3.1 & 3.1 & .00 & \\
\hline USGS 38 & $10 / 14 / 92$ & 3.5 & 3.4 & .32 & \\
\hline USGS 40 & $10 / 18 / 89$ & 3.4 & 3.4 & .00 & \\
\hline \multirow[t]{2}{*}{ USGS 44} & $10 / 26 / 90$ & 1.1 & 1.1 & .00 & \\
\hline & $11 / 01 / 93$ & 1.2 & 1.2 & .00 & \\
\hline USGS 46 & $10 / 09 / 91$ & 2.5 & 2.5 & .00 & \\
\hline \multirow[t]{2}{*}{ USGS 57} & $12 / 22 / 89$ & 3.4 & 3.4 & .00 & \\
\hline & $10 / 29 / 90$ & 3.5 & 3.5 & .00 & \\
\hline USGS 58 & $10 / 21 / 93$ & 1.2 & 1.2 & .00 & \\
\hline USGS 59 & $10 / 25 / 93$ & 1.4 & 1.5 & .60 & \\
\hline USGS 65 & $10 / 15 / 91$ & 1.5 & 1.5 & .00 & \\
\hline \multirow[t]{2}{*}{ USGS 76} & $10 / 17 / 90$ & 1.1 & 1.1 & .00 & \\
\hline & $10 / 21 / 93$ & 1.1 & ${ }^{\otimes} 1.4$ & 1.98 & $\mathrm{~N}$ \\
\hline USGS 77 & $10 / 09 / 92$ & 4.9 & 4.9 & .00 & \\
\hline USGS 83 & $10 / 11 / 90$ & .80 & .70 & 1.40 & \\
\hline USGS 89 & $10 / 16 / 91$ & 1.8 & 1.8 & .00 & \\
\hline USGS 90 & $10 / 04 / 93$ & .97 & .71 & 2.24 & $\mathbf{N}$ \\
\hline \multirow[t]{4}{*}{ USGS 97} & $6 / 07 / 90$ & 1.8 & 1.8 & .00 & \\
\hline & $12 / 07 / 90$ & 1.8 & 1.8 & .00 & \\
\hline & $6 / 07 / 91$ & 1.9 & 2.0 & .50 & \\
\hline & $11 / 04 / 93$ & 2.0 & 2.0 & .00 & \\
\hline \multirow[t]{2}{*}{ USGS 98} & $7 / 30 / 90$ & 1.1 & 1.1 & .00 & \\
\hline & $9 / 21 / 92$ & 1.0 & 1.0 & .00 & \\
\hline \multirow[t]{2}{*}{ USGS 99} & $10 / 03 / 90$ & 1.5 & 1.5 & .00 & \\
\hline & $6 / 16 / 92$ & 1.5 & 1.5 & .00 & \\
\hline \multirow[t]{2}{*}{ USGS 102} & $12 / 10 / 90$ & 1.7 & 1.7 & .00 & \\
\hline & $12 / 09 / 92$ & 1.9 & 1.9 & .00 & \\
\hline \multirow[t]{2}{*}{ USGS 104} & $10 / 16 / 89$ & .66 & .65 & .09 & \\
\hline & $9 / 29 / 92$ & .72 & .72 & .00 & \\
\hline \multirow[t]{3}{*}{ USGS 114} & $10 / 05 / 89$ & 4.0 & 4.1 & .28 & \\
\hline & $9 / 24 / 90$ & 3.9 & 3.9 & .00 & \\
\hline & $10 / 21 / 91$ & 4.0 & 3.9 & .29 & \\
\hline USGS 116 & $10 / 05 / 89$ & 3.1 & 3.1 & .00 & \\
\hline USGS 122 & $10 / 15 / 91$ & 2.9 & 2.9 & .00 & \\
\hline
\end{tabular}


Table 17. Comparison of results of replicate pairs of samples from the Idaho National Engineering Laboratory analyzed for dissolved ammonia plus organic nitrogen, as nitrogen, by the National Water Quality Laboratory

[Site identifier: see figures 1-3 for location of sites; QA: quality-assurance replicate sample. Z-value: see section on Statistical Comparisons of Replicate Pairs of Samples for explanation. Abbreviations: mg/L, milligram per liter; U, statistical agreement of the analytical result is uncertain; $N$, the analytical results are not in statistical agreement. Symbol: <, the result was less than the indicated reporting level]

\begin{tabular}{lccccc}
\hline Site identifier & Date sampled & $\begin{array}{c}\text { Dissolved } \\
\text { ammonia plus } \\
\text { organic } \\
\text { nitrogen, as } \\
\text { nitrogen } \\
(\mathrm{mg} / \mathrm{L})\end{array}$ & $\begin{array}{c}\text { Dissolved } \\
\text { ammonia plus } \\
\text { organic } \\
\text { nitrogen, as } \\
\text { nitrogen QA } \\
(\mathrm{mg} / \mathrm{L})\end{array}$ & Z-value & Remark \\
\hline NRF-1 & $9 / 09 / 91$ & 0.3 & 0.3 & 0.00 & $\mathrm{U}$ \\
NRF-2 & $3 / 05 / 91$ & $<.2$ & .3 & & \\
NRF-3 & $6 / 17 / 91$ & .2 & .4 & 1.37 & $\mathrm{~N}$ \\
NRF-4 & $2 / 07 / 91$ & 1.1 & .5 & 2.40 & .65 \\
WSINEL1 & $12 / 07 / 90$ & .3 & .4 & .74 & \\
USGS 12 & $9 / 06 / 91$ & .3 & .2 & 0 & \\
USGS 17 & $3 / 13 / 91$ & $<.2$ & $<.2$ & 0 & \\
USGS 97 & $12 / 07 / 90$ & $<.2$ & $<.2$ & .00 & \\
USGS 99 & $6 / 07 / 91$ & .2 & .2 & 1.21 & \\
USGS 102 & $10 / 03 / 90$ & .3 & .5 & .00 & \\
\hline
\end{tabular}


Table 18. Comparison of results of replicate pairs of samples from the Idaho National Engineering Laboratory analyzed for dissolved ammonia, as nitrogen, by the National Water Quality Laboratory

[Site identifier: see figures 1-3 for location of sites. QA: quality-assurance replicate sample. Z-value: see section on Statistical Comparisons of Replicate Pairs of Samples for explanation. Remark: the results of replicate pairs are statistically equivalent. Abbreviations: $\mathrm{mg} / \mathrm{L}$, milligram per liter. Symbols: $<$, the result was less than the indicated reporting level; ${ }^{\otimes}$, the QA sample was collected within 24 hours]

\begin{tabular}{|c|c|c|c|c|c|}
\hline Site identifier & Date sampled & $\begin{array}{l}\text { Dissolved } \\
\text { ammonia, as } \\
\text { nitrogen } \\
(\mathrm{mg} / \mathrm{L})\end{array}$ & $\begin{array}{c}\text { Dissolved } \\
\text { ammonia, as } \\
\text { nitrogen QA } \\
(\mathrm{mg} / \mathrm{L})\end{array}$ & $Z$-value & Remarks \\
\hline Area II & $7 / 14 / 93$ & 0.02 & 0.02 & 0.00 & \\
\hline \multirow[t]{2}{*}{ CPP 1} & $11 / 06 / 89$ & .03 & .03 & .00 & \\
\hline & $10 / 31 / 90$ & $<.01$ & .02 & .42 & \\
\hline Fire Station 2 & $10 / 08 / 92$ & .01 & .01 & .00 & \\
\hline MTR Test & $10 / 07 / 92$ & .01 & .01 & .00 & \\
\hline NRF-2 & $9 / 15 / 93$ & .02 & .02 & .00 & \\
\hline NRF-3 & $12 / 03 / 92$ & $<.01$ & $<.01$ & 0 & \\
\hline \multirow[t]{2}{*}{ NRF-4 } & $2 / 07 / 91$ & .01 & .02 & .42 & \\
\hline & $4 / 07 / 93$ & $<.01$ & $<.01$ & 0 & \\
\hline NRF-6 & $3 / 10 / 92$ & .02 & .02 & .00 & \\
\hline NRF-7 & $1 / 08 / 92$ & $<.01$ & $<.01$ & 0 & \\
\hline PW-1 & $10 / 27 / 89$ & .03 & .02 & .30 & \\
\hline RWMC Prod. & $10 / 30 / 90$ & $<.01$ & $<.01$ & 0 & \\
\hline Site 9 & $9 / 27 / 91$ & .01 & .03 & .82 & \\
\hline Site 14 & $11 / 04 / 93$ & .01 & .02 & .42 & \\
\hline TRA Disp. & $10 / 11 / 90$ & $<.01$ & $<.01$ & 0 & \\
\hline \multirow[t]{2}{*}{ WSINEL 1} & $12 / 07 / 90$ & .02 & .02 & .00 & \\
\hline & $12 / 03 / 91$ & .02 & .02 & .00 & \\
\hline USGS 1 & $7 / 20 / 92$ & $<.01$ & .01 & 0 & \\
\hline USGS 12 & $11 / 05 / 93$ & .02 & .02 & .00 & \\
\hline USGS 15 & $3 / 12 / 92$ & $<.01$ & .04 & 1.20 & \\
\hline USGS 17 & $6 / 11 / 93$ & .02 & .02 & .00 & \\
\hline USGS 19 & $10 / 01 / 92$ & $<.01$ & $<.01$ & 0 & \\
\hline USGS 23 & $7 / 09 / 93$ & .02 & .02 & .00 & \\
\hline USGS 32 & $7 / 06 / 92$ & .03 & .02 & .42 & \\
\hline \multirow[t]{2}{*}{ USGS 35} & $10 / 07 / 91$ & $<.01$ & $<.01$ & 0 & \\
\hline & $10 / 20 / 93$ & .02 & ${ }^{\otimes}<.01$ & .42 & \\
\hline USGS 37 & $10 / 21 / 93$ & $<.01$ & $<.01$ & 0 & \\
\hline USGS 38 & $10 / 14 / 92$ & .03 & .02 & .42 & \\
\hline USGS 40 & $10 / 18 / 89$ & .01 & $<.01$ & 0 & \\
\hline \multirow[t]{2}{*}{ USGS 44} & $10 / 26 / 90$ & $<.01$ & .01 & .46 & \\
\hline & $11 / 01 / 93$ & .02 & .02 & .00 & \\
\hline USGS 46 & $10 / 09 / 91$ & $<.01$ & $<.01$ & 0 & \\
\hline
\end{tabular}


Table 18. Comparison of results of replicate pairs of samples from the Idaho National Engineering Laboratory analyzed for dissolved ammonia, as nitrogen, by the National Water Quality Laboratory -continued

\begin{tabular}{|c|c|c|c|c|c|}
\hline Site identifier & Date sampled & $\begin{array}{c}\text { Dissolved } \\
\text { ammonia, as } \\
\text { nitrogen } \\
(\mathrm{mg} / \mathrm{L})\end{array}$ & $\begin{array}{c}\text { Dissolved } \\
\text { ammonia, as } \\
\text { nitrogen QA } \\
(\mathrm{mg} / \mathrm{L})\end{array}$ & Z-value & Remarks \\
\hline \multirow[t]{2}{*}{ USGS 57} & $12 / 22 / 89$ & 0.02 & 0.02 & 0.00 & \\
\hline & $10 / 29 / 90$ & .11 & .11 & .00 & \\
\hline USGS 58 & $10 / 21 / 93$ & $<.01$ & $<.01$ & 0 & \\
\hline USGS 59 & $10 / 25 / 93$ & .02 & .02 & .00 & \\
\hline USGS 65 & $10 / 15 / 91$ & $<.01$ & $<.01$ & 0 & \\
\hline \multirow[t]{2}{*}{ USGS 76} & $10 / 17 / 90$ & .01 & $<.01$ & 0 & \\
\hline & $10 / 21 / 93$ & $<.01$ & $\otimes<.01$ & 0 & \\
\hline USGS 77 & $10 / 09 / 92$ & .01 & .02 & .44 & \\
\hline USGS 83 & $10 / 11 / 90$ & $<.01$ & $<.01$ & 0 & \\
\hline USGS 89 & $10 / 16 / 91$ & $<.01$ & $<.01$ & 0 & \\
\hline USGS 90 & $10 / 04 / 93$ & .01 & .01 & .00 & \\
\hline \multirow[t]{3}{*}{ USGS 97} & $12 / 07 / 90$ & $<.01$ & .01 & 0 & \\
\hline & $6 / 07 / 91$ & $<.01$ & $<.01$ & 0 & \\
\hline & $11 / 04 / 93$ & .01 & .02 & .44 & \\
\hline USGS 98 & $9 / 21 / 92$ & $<.01$ & .02 & .42 & \\
\hline \multirow[t]{2}{*}{ USGS 99} & $10 / 03 / 90$ & $<.01$ & $<.01$ & 0 & \\
\hline & $6 / 16 / 92$ & .02 & .01 & .44 & \\
\hline \multirow[t]{2}{*}{ USGS 102} & $12 / 10 / 90$ & $<.01$ & $<.01$ & 0 & \\
\hline & $12 / 09 / 92$ & $<.01$ & $<.01$ & 0 & \\
\hline \multirow[t]{2}{*}{ USGS 104} & $10 / 16 / 89$ & $<.01$ & $<.01$ & 0 & \\
\hline & $9 / 29 / 92$ & $<.01$ & $<.01$ & 0 & \\
\hline \multirow[t]{3}{*}{ USGS 114} & $10 / 05 / 89$ & .03 & .01 & .86 & \\
\hline & $9 / 24 / 90$ & $<.01$ & $<.01$ & 0 & \\
\hline & $10 / 21 / 91$ & .02 & .02 & .00 & \\
\hline USGS 116 & $10 / 05 / 89$ & .02 & .02 & .00 & \\
\hline USGS 122 & $10 / 15 / 91$ & $<.01$ & $<.01$ & 0 & \\
\hline
\end{tabular}


Table 19. Comparison of results of replicate pairs of samples from the Idaho National Engineering Laboratory analyzed for orthophosphate, as dissolved phosphorus by the National Water Quality Laboratory

[Site identifier: see figures 1-3 for location of sites. QA: quality-assurance replicate sample. Z-value: see section on Statistical Comparisons of Replicate Pairs of Samples for explanation. Abbreviations: mg/L, milligram per liter; U, statistical agreement of the analytical result is uncertain; $\mathrm{N}$, the analytical results are not in statistical agreement. Symbols: $<$, the result was less than the indicated reporting level; ${ }^{\otimes}$, the QA sample was collected within 24 hours]

\begin{tabular}{|c|c|c|c|c|c|}
\hline Site identifier & Date sampled & $\begin{array}{c}\text { Orthophosphate, } \\
\text { as dissolved } \\
\text { phosphorus } \\
(\mathrm{mg} / \mathrm{L})\end{array}$ & $\begin{array}{c}\text { Orthophosphate, } \\
\text { as dissolved } \\
\text { phosphorus QA } \\
(\mathrm{mg} / \mathrm{L})\end{array}$ & Z-value & Remark \\
\hline Area II & $7 / 14 / 93$ & $<0.01$ & $<0.01$ & 0.00 & \\
\hline \multirow[t]{2}{*}{ CPP 1} & $11 / 06 / 89$ & .03 & .04 & 1.40 & \\
\hline & $10 / 31 / 90$ & .03 & $<.01$ & & $\mathrm{U}$ \\
\hline Fire Station 2 & $10 / 08 / 92$ & .02 & .02 & .00 & \\
\hline MTR Test & $10 / 07 / 92$ & .01 & .01 & .00 & \\
\hline NRF-1 & $9 / 09 / 91$ & $<.01$ & $<.01$ & 0 & \\
\hline \multirow[t]{2}{*}{ NRF-2 } & $3 / 05 / 91$ & .02 & .02 & .00 & \\
\hline & $9 / 15 / 93$ & .03 & .02 & 1.59 & \\
\hline \multirow[t]{2}{*}{ NRF-3 } & $6 / 17 / 91$ & .03 & .02 & 1.59 & \\
\hline & $12 / 03 / 92$ & .02 & .02 & .00 & \\
\hline \multirow[t]{2}{*}{ NRF-4 } & 2/07/91 & .02 & .04 & 2.96 & $\mathbf{N}$ \\
\hline & $4 / 07 / 93$ & .02 & .02 & .00 & \\
\hline NRF-6 & $3 / 10 / 92$ & .07 & .07 & .00 & \\
\hline NRF-7 & $1 / 08 / 92$ & .02 & .01 & 1.82 & \\
\hline PW-1 & $10 / 27 / 89$ & .07 & .08 & .82 & \\
\hline RWMC Prod. & $10 / 30 / 90$ & $<.01$ & $<.01$ & 0 & \\
\hline Site 9 & $9 / 27 / 91$ & .02 & .03 & 1.59 & \\
\hline Site 14 & $11 / 04 / 93$ & .02 & .03 & 1.59 & \\
\hline TRA Disp. & $10 / 11 / 90$ & .04 & .08 & 4.17 & $\mathbf{N}$ \\
\hline \multirow[t]{2}{*}{ WSINEL1 } & $12 / 07 / 90$ & .01 & .01 & .00 & \\
\hline & $12 / 03 / 91$ & .01 & .01 & .00 & \\
\hline USGS 1 & $7 / 20 / 92$ & $<.01$ & $<.01$ & 0 & \\
\hline \multirow[t]{2}{*}{ USGS 12} & $9 / 06 / 91$ & $<.01$ & $<.01$ & 0 & \\
\hline & $11 / 05 / 93$ & .03 & .02 & 1.59 & \\
\hline USGS 15 & $3 / 12 / 92$ & .01 & .02 & 1.82 & \\
\hline \multirow[t]{2}{*}{ USGS 17} & $3 / 13 / 91$ & .01 & .01 & .00 & \\
\hline & $6 / 11 / 93$ & .03 & .02 & 1.59 & \\
\hline USGS 19 & $10 / 01 / 92$ & .01 & $<.01$ & & $\mathrm{U}$ \\
\hline USGS 23 & $7 / 09 / 93$ & $<.01$ & $<.01$ & 0 & \\
\hline USGS 32 & $7 / 06 / 92$ & $<.01$ & $<.01$ & 0 & \\
\hline \multirow[t]{2}{*}{ USGS 35} & $10 / 07 / 91$ & .03 & .03 & .00 & \\
\hline & $10 / 20 / 93$ & .03 & ${ }^{\otimes} .03$ & .00 & \\
\hline USGS 37 & $10 / 21 / 93$ & .02 & .02 & .00 & \\
\hline
\end{tabular}


Table 19. Comparison of results of replicate pairs of samples from the Idaho National Engineering Laboratory analyzed for orthophosphate, as dissolved phosphorus by the National Water Quality Laboratory -continued

\begin{tabular}{|c|c|c|c|c|c|}
\hline Site identifier & Date sampled & $\begin{array}{l}\text { Orthophosphate, } \\
\text { as dissolved } \\
\text { phosphorus } \\
\text { (mg/L) }\end{array}$ & $\begin{array}{c}\text { Orthophosphate, } \\
\text { as dissolved } \\
\text { phosphorus QA } \\
\text { (mg/L) }\end{array}$ & $Z$-value & Remark \\
\hline USGS 38 & $10 / 14 / 92$ & .02 & .02 & 0.00 & \\
\hline USGS 40 & $10 / 18 / 89$ & .04 & .02 & 2.96 & $\mathbf{N}$ \\
\hline \multirow[t]{2}{*}{ USGS 44} & $10 / 26 / 90$ & .01 & .01 & .00 & \\
\hline & $11 / 01 / 93$ & .02 & .02 & .00 & \\
\hline USGS 46 & $10 / 09 / 91$ & .03 & .02 & 1.59 & \\
\hline \multirow[t]{2}{*}{ USGS 57} & $12 / 22 / 89$ & .17 & .12 & 2.56 & $\mathrm{~N}$ \\
\hline & $10 / 29 / 90$ & .01 & .02 & 1.82 & \\
\hline USGS 58 & $10 / 21 / 93$ & .02 & .02 & .00 & \\
\hline USGS 59 & $10 / 25 / 93$ & .02 & .02 & .00 & \\
\hline USGS 65 & $10 / 15 / 91$ & .01 & .01 & .00 & \\
\hline \multirow[t]{2}{*}{ USGS 76} & $10 / 17 / 90$ & $<.01$ & $<.01$ & 0 & \\
\hline & $10 / 21 / 93$ & .02 & $\otimes .02$ & .00 & \\
\hline USGS 77 & $10 / 09 / 92$ & .01 & .01 & .00 & \\
\hline USGS 83 & $10 / 11 / 90$ & $<.01$ & $<.01$ & 0 & \\
\hline USGS 89 & $10 / 16 / 91$ & .01 & $<.01$ & & $\mathbf{U}$ \\
\hline USGS 90 & $10 / 04 / 93$ & .01 & .02 & 1.82 & \\
\hline \multirow[t]{3}{*}{ USGS 97} & $12 / 07 / 90$ & .02 & .03 & 1.59 & \\
\hline & $6 / 07 / 91$ & .02 & .01 & & $\mathrm{U}$ \\
\hline & $11 / 04 / 93$ & .03 & .04 & 1.40 & \\
\hline USGS 98 & $9 / 21 / 92$ & .01 & .02 & 1.82 & \\
\hline \multirow[t]{2}{*}{ USGS 99} & $10 / 03 / 90$ & .01 & $<.01$ & & $\mathrm{U}$ \\
\hline & $6 / 16 / 92$ & .02 & .02 & .00 & \\
\hline \multirow[t]{2}{*}{ USGS 102} & $12 / 10 / 90$ & .02 & .02 & .00 & \\
\hline & $12 / 09 / 92$ & .02 & .02 & .00 & \\
\hline \multirow[t]{2}{*}{ USGS 104} & $10 / 16 / 89$ & .04 & .04 & .00 & \\
\hline & $9 / 29 / 92$ & .01 & .02 & 1.82 & \\
\hline \multirow[t]{3}{*}{ USGS 114} & $10 / 05 / 89$ & .02 & .02 & .00 & \\
\hline & $9 / 24 / 90$ & $<.01$ & .03 & & $\mathrm{U}$ \\
\hline & $10 / 21 / 91$ & .02 & .02 & .00 & \\
\hline USGS 116 & $10 / 05 / 89$ & .02 & .02 & .00 & \\
\hline USGS 122 & $10 / 15 / 91$ & .01 & .01 & .00 & \\
\hline
\end{tabular}


Table 20. Comparison of results of replicate pairs of samples from the Idaho National Engineering Laboratory analyzed for arsenic by the National Water Quality Laboratory

[Site identifier: see figures 1-3 for location of sites. QA: quality-assurance replicate sample. Z-value: see section on Statistical Comparisons of Replicate Pairs of Samples for explanation. Abbreviations: $\mu \mathrm{g} / \mathrm{L}$, microgram per liter; $\mathrm{N}$, the analytical results are not in statistical agreement. Symbol: **, the water sample was analyzed for dissolved arsenic, rather than total recoverable arsenic; <, the result was less than the indicated reporting level]

\begin{tabular}{llcccc}
\hline Site identifier & Date sampled & $\begin{array}{c}\text { Arsenic } \\
(\mu \mathrm{g} / \mathrm{L})\end{array}$ & $\begin{array}{c}\text { Arsenic QA } \\
(\mu \mathrm{g} / \mathrm{L})\end{array}$ & Z-value & Remark \\
\hline NRF-2 & $3 / 21 / 90$ & 2 & 2 & 0.00 & .00 \\
NRF-4 & $2 / 07 / 91$ & 2 & 2 & .00 & \\
NRF-6 & $3 / 10 / 92$ & 4 & 4 & .87 & \\
NRF-7 & $1 / 08 / 92$ & 2 & $<1$ & .00 & \\
WSINEL1 & $12 / 07 / 90$ & 1 & 1 & .00 & $\mathrm{~N}$ \\
USGS 12 & $6 / 15 / 90$ & 2 & 2 & 3.79 & .00 \\
USGS 15 & $8 / 06 / 90$ & 2 & 12 & .00 & .87 \\
USGS 44 & $10 / 26 / 90$ & $* * 1$ & $* * 1$ & .68 & \\
USGS 97 & $6 / 07 / 90$ & 2 & 2 & .00 & \\
& $12 / 07 / 90$ & 2 & 1 & .00 & \\
USGS 98 & $7 / 30 / 90$ & 2 & 1 & .00 & \\
USGS 99 & $10 / 03 / 90$ & 2 & 2 & \\
USGS 102 & $12 / 10 / 90$ & 2 & 2 & \\
USGS 122 & $10 / 15 / 91$ & $* * 2$ & $* * 2$ & \\
\hline
\end{tabular}


Table 21. Comparison of results of replicate pairs of samples from the Idaho National Engineering Laboratory analyzed for barium by the National Water Quality Laboratory

[Site identifier: see figures 1-3 for location of sites. QA: quality-assurance replicate sample. Z-value: see section on Statistical Comparisons of Replicate Pairs of Samples for explanation. Remark: the results of replicate pairs are statistically equivalent. Abbreviations: $\mu \mathrm{g} / \mathrm{L}$, microgram per liter. Symbols: $<$, the result was less than the indicated reporting level; **, the water sample was analyzed for dissolved barium, rather than total recoverable barium]

\begin{tabular}{lcrccc}
\hline Site identifier & Date sampled & $\begin{array}{c}\text { Barium } \\
(\mu \mathrm{g} / \mathrm{L})\end{array}$ & $\begin{array}{c}\text { Barium QA } \\
(\mu \mathrm{g} / \mathrm{L})\end{array}$ & Z-value & Remark \\
\hline NRF-2 & $3 / 21 / 90$ & $<100$ & $<100$ & 0 \\
NRF-4 & $2 / 07 / 91$ & 100 & 100 & .00 \\
NRF-6 & $3 / 10 / 92$ & $<100$ & 100 & .00 \\
NRF-7 & $1 / 08 / 92$ & 100 & 100 & .00 \\
WSINEL1 & $12 / 07 / 90$ & $<100$ & $<100$ & 0 \\
USGS 12 & $6 / 15 / 90$ & 100 & 100 & .00 \\
USGS 15 & $8 / 06 / 90$ & $<100$ & $<100$ & 0 \\
USGS 44 & $10 / 26 / 90$ & $* * 90$ & $* * 89$ & .12 \\
USGS 97 & $6 / 07 / 90$ & 100 & 100 & .00 \\
& $12 / 07 / 90$ & $<100$ & $<100$ & 0 \\
USGS 98 & $7 / 30 / 90$ & $<100$ & $<100$ & 0 \\
USGS 99 & $10 / 03 / 90$ & $<100$ & $<100$ & 0 \\
USGS 102 & $12 / 10 / 90$ & 100 & 100 & .00 \\
USGS 122 & $10 / 15 / 91$ & $* * 110$ & $* * 110$ & .00 \\
\hline
\end{tabular}


Table 22. Comparison of results of replicate pairs of samples from the Idaho National Engineering Laboratory analyzed for cadmium by the National Water Quality Laboratory

Site identifier: see figures 1-3 for location of sites. QA: quality-assurance replicate sample. Z-value: see section on Statistical Comparisons of Replicate Pairs of Samples for explanation. Remark: the results of replicate pairs are statistically equivalent. Abbreviations: $\mu \mathrm{g} / \mathrm{L}$, microgram per liter. Symbols: $<$, the result was less than the indicated reporting level; **, the water sample was analyzed for dissolved cadmium, rather than total recoverable cadmium]

\begin{tabular}{lccccc}
\hline Site identifier & Date sampled & $\begin{array}{c}\text { Cadmium } \\
(\mu \mathrm{g} / \mathrm{L})\end{array}$ & $\begin{array}{c}\text { Cadmium QA } \\
(\mu \mathrm{g} / \mathrm{L})\end{array}$ & Z-value & Remark \\
\hline NRF-2 & $3 / 21 / 90$ & $<1$ & $<1$ & 0 \\
NRF-4 & $2 / 07 / 91$ & $<1$ & $<1$ & 0 \\
NRF-6 & $3 / 10 / 92$ & $<1$ & $<1$ & 0 \\
NRF-7 & $1 / 08 / 92$ & $<1$ & $<1$ & 0 \\
WSINEL1 & $12 / 07 / 90$ & $<1$ & $<1$ & 0 \\
USGS 12 & $6 / 15 / 90$ & $<1$ & $<1$ & 0 \\
USGS 15 & $8 / 06 / 90$ & $<1$ & $<1$ & 0 \\
USGS 44 & $10 / 26 / 90$ & $* *<1$ & $* *<1$ & 0 \\
USGS 97 & $6 / 07 / 90$ & $<1$ & $<1$ & 0 \\
& $12 / 07 / 90$ & $<1$ & $<1$ & 0 \\
USGS 98 & $7 / 30 / 90$ & $<1$ & $<1$ & 0 \\
USGS 99 & $10 / 03 / 90$ & $<1$ & $<1$ & 0 \\
USGS 102 & $12 / 10 / 90$ & $<1$ & $<1$ & 0 \\
USGS 122 & $10 / 15 / 91$ & $* *<1$ & $* *<1$ & 0 \\
\hline
\end{tabular}


Table 23. Comparison of results of replicate pairs of samples from the Idaho National Engineering Laboratory analyzed for chromium by the National Water Quality Laboratory and the Radiological and Environmental Sciences Laboratory

[Site identifier: see figures 1-3 for location of sites. QA: quality-assurance replicate sample. Z-value: see section on Statistical Comparisons of Replicate Pairs of Samples for explanation. Abbreviations: $\mu \mathrm{g} / \mathrm{L}$, microgram per liter; $\mathrm{N}$, the analytical results are not in statistical agreement. Symbols: <, the result was less than the indicated reporting level; *, the water sample was analyzed for total recoverable chromium, rather than dissolved chromium; ${ }^{\#}$, the analysis was performed by the Radiological and Environmental Sciences Laboratory; ${ }^{\otimes}$, the QA sample was collected within 24 hours]

\begin{tabular}{|c|c|c|c|c|c|c|c|c|c|}
\hline Site identifier & Date sampled & $\begin{array}{l}\text { Chromium } \\
(\mu \mathrm{g} / \mathrm{L})\end{array}$ & $\begin{array}{c}\text { Chromium QA } \\
(\mu \mathrm{g} / \mathrm{L})\end{array}$ & Z-value & Remarks & $\begin{array}{l}\text { Hexavalent } \\
\text { chromium } \\
(\mu \mathrm{g} / \mathrm{L})\end{array}$ & $\begin{array}{c}\text { Hexavalent } \\
\text { chromium QA } \\
\underset{(\mu \mathrm{g} / \mathrm{L})}{ }\end{array}$ & $Z$-value & Remark \\
\hline ARBOR Test & $10 / 01 / 91$ & $<1$ & 2 & 0 & & $<1$ & $<1$ & 0 & \\
\hline CFA-2 & $7 / 25 / 91$ & 10 & 10 & .00 & & 6 & 5 & .29 & \\
\hline \multirow[t]{2}{*}{ CPP 1} & $11 / 06 / 89$ & $* 2$ & $* 4$ & .60 & & 7 & 7 & .00 & \\
\hline & $10 / 31 / 90$ & 4 & 5 & .29 & & & & & \\
\hline \multirow[t]{2}{*}{ CPP 2} & $1 / 31 / 89$ & ${ }^{\# .01 \pm 0.02}$ & $\#_{-.01 \pm 0.02}$ & .00 & & & & & \\
\hline & $4 / 29 / 92$ & 4 & 5 & .29 & & 6 & 6 & .00 & \\
\hline CPP 4 & $7 / 23 / 90$ & $* 8$ & $* 8$ & .00 & & & & & \\
\hline \multirow[t]{2}{*}{ CWP-4 } & $4 / 25 / 89$ & ${ }^{\#} .01 \pm 0.02$ & $\#_{-.01 \pm 0.02}$ & .00 & & & & & \\
\hline & $4 / 17 / 91$ & $<1$ & 1 & 0 & & $<1$ & $<1$ & 0 & \\
\hline CWP-5 & $10 / 14 / 93$ & 3 & 2 & .30 & & $<1$ & 1 & 0 & \\
\hline \multirow[t]{2}{*}{ Fire St 2} & $4 / 18 / 91$ & 4 & 2 & .60 & & 5 & 5 & .00 & \\
\hline & $10 / 08 / 92$ & 5 & 4 & .29 & & 2 & 2 & .00 & \\
\hline MTR Test & $10 / 07 / 92$ & 6 & 6 & .00 & & $<1$ & $<1$ & 0 & \\
\hline NRF-1 & 9/09/91 & $* 12$ & $* 11$ & .26 & & & & & \\
\hline \multirow[t]{4}{*}{ NRF-2 } & $3 / 21 / 90$ & *14 & $* 14$ & .00 & & & & & \\
\hline & $3 / 21 / 90$ & *14 & *14 & .00 & & & & & \\
\hline & $3 / 05 / 91$ & $* 14$ & $* 15$ & .24 & & & & & \\
\hline & $9 / 15 / 93$ & $* 9$ & $* 10$ & .27 & & & & & \\
\hline \multirow[t]{2}{*}{ NRF-3 } & $6 / 17 / 91$ & $* 7$ & $* 7$ & .00 & & & & & \\
\hline & $12 / 03 / 92$ & $* 10$ & $* 4$ & 1.67 & & & & & \\
\hline \multirow[t]{2}{*}{$N R F-4$} & $2 / 07 / 91$ & $* 10$ & $* 10$ & .00 & & & & & \\
\hline & $4 / 07 / 93$ & $* 9$ & $* 9$ & .00 & & & & & \\
\hline NRF-6 & $3 / 10 / 92$ & $* 45$ & $* 43$ & .33 & & & & & \\
\hline NRF-7 & $1 / 08 / 92$ & $* 9$ & $* 8$ & .27 & & & & & \\
\hline
\end{tabular}


Table 23. Comparison of results of replicate pairs of samples from the Idaho National Engineering Laboratory analyzed for chromium by the National Water Quality Laboratory and the Radiological and Environmental Sciences Laboratory-continued

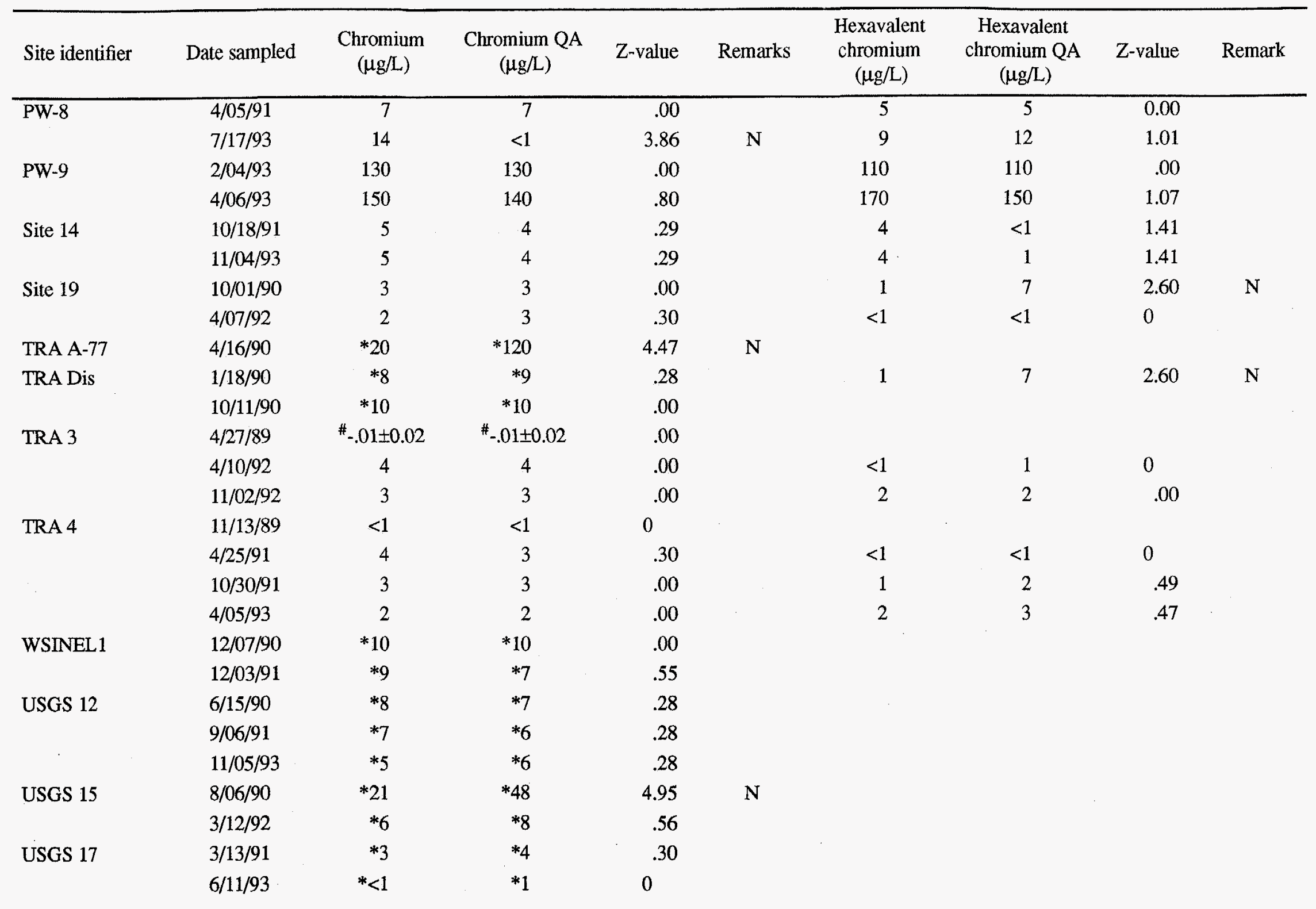


Table 23. Comparison of results of replicate pairs of samples from the Idaho National Engineering Laboratory analyzed for chromium by the National Water Quality Laboratory and the Radiological and Environmental Sciences Laboratory-continued

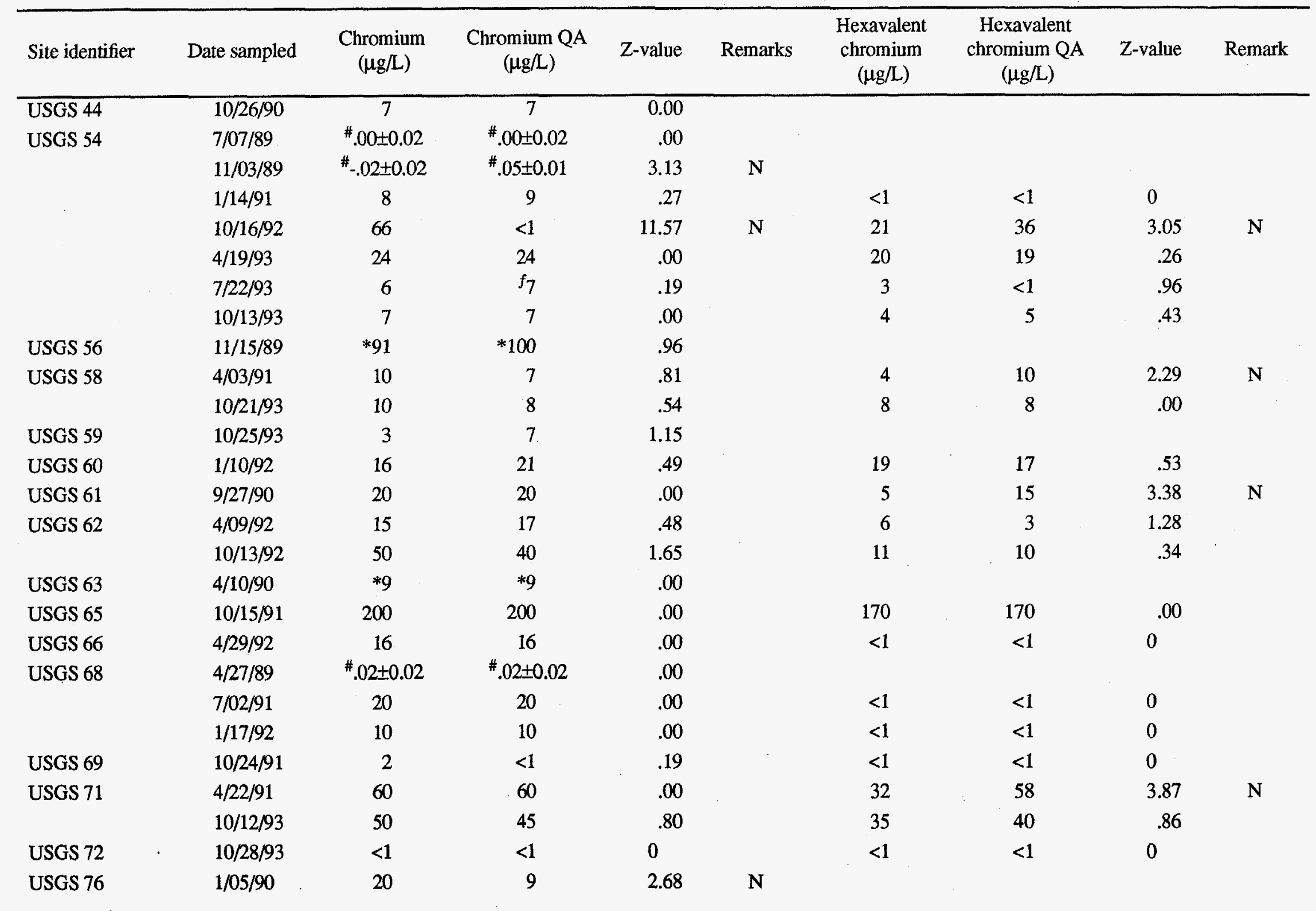


Table 23. Comparison of results of replicate pairs of samples from the Idaho National Engineering Laboratory analyzed for chromium by the National Water Quality Laboratory and the Radiological and Environmental Sciences Laboratory-continued

\begin{tabular}{|c|c|c|c|c|c|c|c|c|c|}
\hline Site identifier & Date sampled & $\begin{array}{l}\text { Chromium } \\
(\mu \mathrm{g} / \mathrm{L})\end{array}$ & $\underset{(\mu \mathrm{g} / \mathrm{L})}{\text { Chromium }} \mathrm{QA}$ & $\mathrm{Z}$-value & Remarks & $\begin{array}{l}\text { Hexavalent } \\
\text { chromium } \\
(\mu \mathrm{g} / \mathrm{L})\end{array}$ & $\begin{array}{c}\text { Hexavalent } \\
\text { chromium QA } \\
(\mu \mathrm{g} / \mathrm{L})\end{array}$ & Z-value & Remark \\
\hline \multirow[t]{3}{*}{ USGS 76 - cont. } & $10 / 17 / 90$ & 10 & 10 & 0.00 & & 11 & 12 & 0.33 & \\
\hline & $4 / 26 / 93$ & 11 & 10 & .26 & & 12 & $<1$ & 4.21 & $\mathrm{~N}$ \\
\hline & $10 / 21 / 93$ & 11 & $f_{9}$ & .53 & & 10 & 10 & .00 & \\
\hline USGS 84 & $10 / 09 / 92$ & 25 & 24 & .21 & & 25 & 22 & .69 & \\
\hline \multirow[t]{5}{*}{ USGS 97} & $6 / 07 / 90$ & $* 8$ & $* 9$ & .27 & & & & & \\
\hline & $6 / 07 / 90$ & $* 8$ & $* 9$ & .27 & & & & & \\
\hline & $12 / 07 / 90$ & $* 7$ & $* 7$ & .00 & & & & & \\
\hline & $6 / 07 / 91$ & $* 5$ & $* 8$ & .84 & & & & & \\
\hline & $11 / 04 / 93$ & *7 & *13 & 1.58 & & & & & \\
\hline \multirow[t]{2}{*}{ USGS 98} & $7 / 30 / 90$ & $* 8$ & $* 7$ & .28 & & & & & \\
\hline & $9 / 21 / 92$ & *5 & $* 4$ & .29 & & & & & \\
\hline \multirow[t]{2}{*}{ USGS 99} & $10 / 03 / 90$ & $* 5$ & $* 6$ & .29 & & & & & \\
\hline & $6 / 16 / 92$ & *3 & $* 2$ & .30 & & & & & \\
\hline \multirow[t]{3}{*}{ USGS 100} & $1 / 07 / 91$ & 2 & 2 & .00 & & & & & \\
\hline & $10 / 05 / 92$ & 1 & $<1$ & 0 & & $<1$ & $<1$ & 0 & \\
\hline & $4 / 23 / 93$ & 2 & 1 & .31 & & $<1$ & $<1$ & .19 & \\
\hline \multirow[t]{2}{*}{ USGS 102} & $12 / 10 / 90$ & $* 8$ & $* 8$ & .00 & & & & & \\
\hline & $12 / 09 / 92$ & $* 4$ & $* 8$ & 1.13 & & & & & \\
\hline USGS 122 & $10 / 15 / 91$ & 9 & 8 & .27 & & & & & \\
\hline
\end{tabular}


Table 24. Comparison of results of replicate pairs of samples from the Idaho National Engineering Laboratory analyzed for copper by the National Water Quality Laboratory

[Site identifier: see figures 1-3 for location of sites. QA: quality-assurance replicate sample. Z-value: see section on Statistical Comparisons of Replicate Pairs of Samples for explanation. Abbreviations: $\mu \mathrm{g} / \mathrm{L}$, microgram per liter; $\mathrm{N}$, the analytical results are not in statistical agreement. Symbols: **, the water sample was analyzed for dissolved copper, rather than total recoverable copper; $<$, the result was less than the indicated reporting level]

\begin{tabular}{lccccc}
\hline Site identifier & Date sampled & $\begin{array}{c}\text { Copper } \\
(\mu \mathrm{g} / \mathrm{L})\end{array}$ & $\begin{array}{c}\text { Copper QA } \\
(\mu \mathrm{g} / \mathrm{L})\end{array}$ & Z-value & Remark \\
\hline NRF-2 & $3 / 21 / 90$ & 16 & 3 & 3.47 & $\mathrm{~N}$ \\
NRF-4 & $2 / 07 / 91$ & 2 & 3 & .32 & \\
NRF-6 & $3 / 10 / 92$ & 5 & 6 & .29 & \\
WSINEL1 & $12 / 07 / 90$ & 2 & 2 & .00 & \\
USGS 12 & $6 / 15 / 90$ & 3 & 3 & .00 & \\
USGS 15 & $8 / 06 / 90$ & 7 & 2 & 1.51 & \\
USGS 97 & $6 / 07 / 90$ & 4 & 3 & .31 & \\
& $12 / 07 / 90$ & 5 & 3 & .61 & .00 \\
USGS 98 & $7 / 30 / 90$ & 1 & 1 & .00 & \\
USGS 99 & $10 / 03 / 90$ & 1 & 1 & .33 & \\
USGS 102 & $12 / 10 / 90$ & 2 & 1 & 0 & \\
USGS 122 & $10 / 15 / 91$ & $* *<10$ & $* *<10$ & \\
\hline
\end{tabular}


Table 25. Comparison of results of replicate pairs of samples from the Idaho National Engineering Laboratory analyzed for iron by the National Water Quality Laboratory

Site identifier: see figures 1-3 for location of sites. QA: quality-assurance replicate sample. Z-value: see section on Statistical Comparisons of Replicate Pairs of Samples for explanation. Abbreviations: $\mu \mathrm{g} / \mathrm{L}$, microgram per liter; $\mathrm{N}$, the analytical results are not in statistical agreement. Symbols: <, the result was less than the indicated reporting level; **, the water sample was analyzed for dissolved iron, rather than total recoverable iron]

\begin{tabular}{|c|c|c|c|c|c|}
\hline Site identifier & Date sampled & $\begin{array}{l}\text { Iron } \\
(\mu \mathrm{g} / \mathrm{L})\end{array}$ & $\begin{array}{c}\text { Iron QA } \\
(\mu \mathrm{g} / \mathrm{L})\end{array}$ & Z-value & Remark \\
\hline NRF-1 & $9 / 09 / 91$ & 470 & 240 & 7.41 & $\mathbf{N}$ \\
\hline \multirow[t]{3}{*}{ NRF-2 } & $3 / 21 / 90$ & 50 & 50 & .00 & \\
\hline & $3 / 05 / 91$ & $<10$ & 10 & 0 & \\
\hline & $9 / 15 / 93$ & 20 & $<10$ & .70 & \\
\hline \multirow[t]{2}{*}{ NRF-3 } & $6 / 17 / 91$ & 60 & 120 & 3.36 & $\mathbf{N}$ \\
\hline & $12 / 03 / 92$ & 320 & 100 & 9.10 & $\mathbf{N}$ \\
\hline \multirow[t]{2}{*}{$\mathrm{NRF}-4$} & $2 / 07 / 91$ & 50 & 30 & 1.30 & \\
\hline & $4 / 07 / 93$ & $<10$ & $<10$ & 0 & \\
\hline NRF-6 & $3 / 10 / 92$ & 120 & 80 & 2.10 & $\mathbf{N}$ \\
\hline NRF-7 & $1 / 08 / 92$ & 330 & 350 & .67 & \\
\hline \multirow[t]{2}{*}{ WSINEL1 } & $12 / 07 / 90$ & 210 & 150 & 2.70 & $\mathbf{N}$ \\
\hline & $12 / 03 / 91$ & 200 & 170 & 1.34 & \\
\hline \multirow[t]{3}{*}{ USGS 12} & $6 / 15 / 90$ & 30 & 50 & 1.30 & \\
\hline & $9 / 06 / 91$ & 50 & 90 & 2.37 & $\mathrm{~N}$ \\
\hline & $11 / 05 / 93$ & 140 & 270 & 5.52 & $\mathrm{~N}$ \\
\hline \multirow[t]{2}{*}{ USGS 15} & $8 / 06 / 90$ & 4,600 & 9,700 & 13.50 & $\mathbf{N}$ \\
\hline & $3 / 12 / 92$ & 10 & $<10$ & 0 & \\
\hline \multirow[t]{2}{*}{ USGS 17} & $3 / 13 / 91$ & 130 & 110 & 1.04 & \\
\hline & $6 / 11 / 93$ & 50 & 30 & 1.30 & \\
\hline \multirow[t]{4}{*}{ USGS 97} & $6 / 07 / 90$ & 90 & 40 & 3.00 & $\mathbf{N}$ \\
\hline & $12 / 07 / 90$ & $<10$ & $<10$ & 0 & \\
\hline & $6 / 07 / 91$ & 30 & 20 & .68 & \\
\hline & $11 / 04 / 93$ & 730 & 390 & 8.25 & $\mathbf{N}$ \\
\hline \multirow[t]{2}{*}{ USGS 98} & $7 / 30 / 90$ & 50 & 40 & .64 & \\
\hline & $9 / 21 / 92$ & 80 & 70 & .58 & \\
\hline \multirow[t]{2}{*}{ USGS 99} & $10 / 03 / 90$ & 230 & 320 & 3.36 & $\mathbf{N}$ \\
\hline & $6 / 16 / 92$ & 40 & 70 & 1.86 & \\
\hline \multirow[t]{2}{*}{ USGS 102} & $12 / 10 / 90$ & 60 & 200 & 6.99 & $\mathbf{N}$ \\
\hline & $12 / 09 / 92$ & 30 & 40 & .66 & \\
\hline USGS 122 & $10 / 15 / 91$ & $* * 20$ & $* * 30$ & .66 & \\
\hline
\end{tabular}


Table 26. Comparison of results of replicate pairs of samples from the Idaho National Engineering Laboratory analyzed for lead by the National Water Quality Laboratory

[Site identifier: see figures 1-3 for location of sites. QA: quality-assurance replicate sample. Z-value: see section on Statistical Comparisons of Replicate Pairs of Samples for explanation. Abbreviations: $\mu \mathrm{g} / \mathrm{L}$, microgram per liter; $N$, the analytical results are not in statistical agreement. Symbols: <, the result was less than the indicated reporting level; **, the water sample was analyzed for dissolved lead, rather than total recoverable lead]

\begin{tabular}{|c|c|c|c|c|c|}
\hline Site identifier & Date sampled & $\begin{array}{l}\text { Lead } \\
(\mu \mathrm{g} / \mathrm{L})\end{array}$ & $\begin{array}{c}\text { Lead QA } \\
(\mu \mathrm{g} / \mathrm{L})\end{array}$ & Z-value & Remark \\
\hline NRF-1 & 9/09/91 & 1 & $<1$ & 0 & \\
\hline \multirow[t]{3}{*}{ NRF-2 } & $3 / 21 / 90$ & 2 & 1 & .31 & \\
\hline & $3 / 05 / 91$ & $<1$ & $<1$ & 0 & \\
\hline & $9 / 15 / 93$ & $<1$ & $<1$ & 0 & \\
\hline \multirow[t]{2}{*}{ NRF-3 } & $6 / 17 / 91$ & 2 & 2 & .00 & \\
\hline & $12 / 03 / 92$ & $<1$ & $<1$ & 0 & \\
\hline \multirow[t]{2}{*}{ NRF-4 } & $4 / 07 / 93$ & $<1$ & $<1$ & 0 & \\
\hline & $2 / 07 / 91$ & $<1$ & 1 & 0 & \\
\hline NRF-6 & $3 / 10 / 92$ & $<1$ & 2 & .64 & \\
\hline NRF-7 & $1 / 08 / 92$ & 4 & 3 & .29 & \\
\hline \multirow[t]{2}{*}{ WSINEL1 } & $12 / 07 / 90$ & 1 & 2 & .31 & \\
\hline & $12 / 03 / 91$ & 3 & $<1$ & 0 & \\
\hline \multirow[t]{3}{*}{ USGS 12} & $6 / 15 / 90$ & 1 & 1 & .00 & \\
\hline & 9/06/91 & $<1$ & $<1$ & 0 & \\
\hline & $11 / 05 / 93$ & $<1$ & $<1$ & 0 & \\
\hline \multirow[t]{2}{*}{ USGS 15} & $8 / 06 / 90$ & 1 & 3 & .61 & \\
\hline & $3 / 12 / 92$ & $<1$ & $<1$ & 0 & \\
\hline \multirow[t]{2}{*}{ USGS 17} & $3 / 13 / 91$ & $<1$ & 1 & 0 & \\
\hline & $6 / 11 / 93$ & $<1$ & $<1$ & 0 & \\
\hline USGS 44 & $10 / 26 / 90$ & $* *<1$ & $* *<1$ & 0 & \\
\hline \multirow[t]{4}{*}{ USGS 97} & $6 / 07 / 90$ & 3 & 3 & .00 & \\
\hline & $12 / 07 / 90$ & 1 & 5 & 1.16 & \\
\hline & $6 / 07 / 91$ & 3 & 3 & .00 & \\
\hline & $11 / 04 / 93$ & 2 & 3 & .57 & \\
\hline \multirow[t]{2}{*}{ USGS 98} & $7 / 30 / 90$ & 1 & 1 & .00 & \\
\hline & $9 / 21 / 92$ & 1 & 1 & .00 & \\
\hline \multirow[t]{2}{*}{ USGS 99} & $10 / 03 / 90$ & 30 & 3 & 4.77 & $\mathbf{N}$ \\
\hline & $6 / 16 / 92$ & 1 & 2 & .31 & \\
\hline \multirow[t]{2}{*}{ USGS 102} & $12 / 10 / 90$ & 1 & 1 & .00 & \\
\hline & $12 / 09 / 92$ & $<1$ & $<1$ & 0 & \\
\hline USGS 122 & $10 / 15 / 91$ & $* *<10$ & $* *<10$ & 0 & \\
\hline
\end{tabular}


Table 27. Comparison of results of replicate pairs of samples from the Idaho National Engineering Laboratory analyzed for manganese by the National Water Quality Laboratory

[Site identifier: see figures 1-3 for location of sites. QA: quality-assurance replicate sample. Z-value: see section on Statistical Comparisons of Replicate Pairs of Samples for explanation. Abbreviations: $\mu \mathrm{g} / \mathrm{L}$, microgram per liter; $\mathrm{N}$, the analytical results are not in statistical agreement; $\mathrm{U}$, statistical agreement of the analytical result is uncertain.

Symbols: <, the result was less than the indicated reporting level; ${ }^{* *}$, the water sample was analyzed for dissolved manganese, rather than total recoverable manganese]

\begin{tabular}{llccll}
\hline Site identifier & Date sampled & $\begin{array}{c}\text { Manganese } \\
(\mu \mathrm{g} / \mathrm{L})\end{array}$ & $\begin{array}{c}\text { Manganese QA } \\
(\mu \mathrm{g} / \mathrm{L})\end{array}$ & Z-value & Remark \\
\hline NRF-2 & $3 / 21 / 90$ & $<10$ & $<10$ & 0 & \\
NRF-4 & $2 / 07 / 91$ & $<10$ & $<10$ & 0 & \\
NRF-6 & $3 / 10 / 92$ & $<10$ & $<10$ & 0 & $\mathrm{U}$ \\
NRF-7 & $1 / 08 / 92$ & $<10$ & $<10$ & 0 & $\mathrm{~N}$ \\
WSINEL1 & $12 / 07 / 90$ & 10 & $<10$ & & \\
USGS 12 & $6 / 15 / 90$ & $<10$ & $<10$ & 0 & \\
USGS 15 & $8 / 06 / 90$ & 100 & 200 & 6.20 & \\
USGS 97 & $6 / 07 / 90$ & $<10$ & $<10$ & 0 & \\
& $12 / 07 / 90$ & $<10$ & $<10$ & 0 & $\mathrm{U}$ \\
USGS 98 & $7 / 30 / 90$ & $<10$ & $<10$ & 0 & .66 \\
USGS 99 & $10 / 03 / 90$ & 30 & 23 & & \\
USGS 102 & $12 / 10 / 90$ & $<10$ & 10 & 9 & \\
USGS 122 & $10 / 15 / 91$ & $* * 12$ & $* * 13$ & & \\
\hline
\end{tabular}


Table 28. Comparison of results of replicate pairs of samples from the Idaho National Engineering Laboratory analyzed for mercury by the National Water Quality Laboratory

[Site identifier: see figures 1-3 for location of sites. QA: quality-assurance replicate sample. Z-value: see section on Statistical Comparisons of Replicate Pairs of Samples for explanation. Remark: the results of replicate pairs are statistically equivalent. Abbreviations: $\mu \mathrm{g} / \mathrm{L}$, microgram per liter. Symbol: $<$, the result was less than the indicated reporting level; ${ }^{* *}$, the water sample was analyzed for dissolved mercury, rather than total recoverable mercury]

\begin{tabular}{|c|c|c|c|c|c|}
\hline Site identifier & Date sampled & $\begin{array}{c}\text { Mercury } \\
(\mu \mathrm{g} / \mathrm{L})\end{array}$ & $\begin{array}{c}\text { Mercury QA } \\
(\mu \mathrm{g} / \mathrm{L})\end{array}$ & $Z$-value & Remark \\
\hline NRF-1 & $9 / 09 / 91$ & $<0.1$ & $<0.1$ & 0 & \\
\hline \multirow[t]{3}{*}{ NRF-2 } & $3 / 21 / 90$ & $<.1$ & $<.1$ & 0 & \\
\hline & $3 / 05 / 91$ & $<.1$ & $<.1$ & 0 & \\
\hline & $9 / 15 / 93$ & $<.1$ & $<.1$ & 0 & \\
\hline \multirow[t]{2}{*}{ NRF-3 } & $6 / 17 / 91$ & $<.1$ & $<.1$ & 0 & \\
\hline & $12 / 03 / 92$ & $<.1$ & $<.1$ & 0 & \\
\hline \multirow[t]{2}{*}{ NRF-4 } & $2 / 07 / 91$ & $<.1$ & $<.1$ & 0 & \\
\hline & $4 / 07 / 93$ & $<.1$ & $<.1$ & 0 & \\
\hline NRF-6 & $3 / 10 / 92$ & $<.1$ & $<.1$ & 0 & \\
\hline NRF-7 & $1 / 08 / 92$ & $<.1$ & $<.1$ & 0 & \\
\hline \multirow[t]{2}{*}{ WSINEL1 } & $12 / 07 / 90$ & $<.1$ & $<.1$ & 0 & \\
\hline & $12 / 03 / 91$ & $<.1$ & $<.1$ & 0 & \\
\hline \multirow[t]{3}{*}{ USGS 12} & $6 / 15 / 90$ & $<.1$ & $<.1$ & 0 & \\
\hline & 9/06/91 & $<.1$ & $<.1$ & 0 & \\
\hline & $11 / 05 / 93$ & $<.1$ & $<.1$ & 0 & \\
\hline \multirow[t]{2}{*}{ USGS 15} & $8 / 06 / 90$ & $<.1$ & .1 & .00 & \\
\hline & $3 / 12 / 92$ & $<.1$ & $<.1$ & 0 & \\
\hline \multirow[t]{2}{*}{ USGS 17} & $3 / 13 / 91$ & $<.1$ & $<.1$ & 0 & \\
\hline & $6 / 11 / 93$ & $<.1$ & $<.1$ & 0 & \\
\hline USGS 44 & $10 / 26 / 90$ & $* * .1$ & $* * .1$ & .00 & \\
\hline \multirow[t]{4}{*}{ USGS 97} & $6 / 07 / 90$ & $<.1$ & $<.1$ & 0 & \\
\hline & $12 / 07 / 90$ & $<.1$ & $<.1$ & 0 & \\
\hline & $6 / 07 / 91$ & $<.1$ & $<.1$ & 0 & \\
\hline & $11 / 04 / 93$ & $<.1$ & $<.1$ & 0 & \\
\hline \multirow[t]{2}{*}{ USGS 98} & $7 / 30 / 90$ & $<.1$ & $<.1$ & 0 & \\
\hline & $9 / 21 / 92$ & $<.1$ & $<.1$ & 0 & \\
\hline \multirow[t]{2}{*}{ USGS 99} & $10 / 03 / 90$ & $<.1$ & $<.1$ & 0 & \\
\hline & $6 / 16 / 92$ & $<.1$ & $<.1$ & 0 & \\
\hline \multirow[t]{2}{*}{ USGS 102} & $12 / 10 / 90$ & $<.1$ & $<.1$ & 0 & \\
\hline & $12 / 09 / 92$ & $<.1$ & $<.1$ & 0 & \\
\hline
\end{tabular}


Table 29. Comparison of results of replicate pairs of samples from the Idaho National Engineering Laboratory analyzed for nickel by the National Water Quality Laboratory

[Site identifier: see figures 1-3 for location of sites. QA: quality-assurance replicate sample. Z-value: see section on Statistical Comparisons of Replicate Pairs of Samples for explanation. Abbreviations: $\mu \mathrm{g} / \mathrm{L}$, microgram per liter; $N$, the analytical results are not in statistical agreement. Symbols: $<$, the result was less than the indicated reporting level; **, the water sample was analyzed for dissolved nickel, rather than total recoverable nickel]

\begin{tabular}{|c|c|c|c|c|c|}
\hline Site identifier & Date sampled & $\begin{array}{l}\text { Nickel } \\
(\mu \mathrm{g} / \mathrm{L})\end{array}$ & $\begin{array}{l}\text { Nickel QA } \\
\quad(\mu \mathrm{g} / \mathrm{L})\end{array}$ & $\mathrm{Z}$-value & Remark \\
\hline NRF-1 & $9 / 09 / 91$ & 2 & 2 & 0.00 & \\
\hline \multirow[t]{3}{*}{ NRF-2 } & $3 / 21 / 90$ & 3 & 2 & .28 & \\
\hline & $3 / 05 / 91$ & $<1$ & $<1$ & 0 & \\
\hline & $9 / 15 / 93$ & $<1$ & $<1$ & 0 & \\
\hline \multirow[t]{2}{*}{ NRF-3 } & $6 / 17 / 91$ & 4 & 3 & .27 & \\
\hline & $12 / 03 / 92$ & 2 & $<1$ & .58 & \\
\hline \multirow[t]{2}{*}{ NRF-4 } & $2 / 07 / 91$ & $<1$ & $<1$ & 0 & \\
\hline & $4 / 07 / 93$ & $<1$ & $<1$ & 0 & \\
\hline NRF-6 & $3 / 10 / 92$ & 21 & 17 & .76 & \\
\hline NRF-7 & $1 / 08 / 92$ & 4 & 3 & .27 & \\
\hline \multirow[t]{2}{*}{ WSINEL1 } & $12 / 07 / 90$ & 2 & $<1$ & .58 & \\
\hline & $12 / 03 / 91$ & 1 & $<1$ & 0 & \\
\hline \multirow[t]{3}{*}{ USGS 12} & $6 / 15 / 90$ & 1 & 2 & .28 & \\
\hline & $9 / 06 / 91$ & 1 & 2 & .28 & \\
\hline & $11 / 05 / 93$ & 2 & 2 & .00 & \\
\hline \multirow[t]{2}{*}{ USGS 15} & $8 / 06 / 90$ & 15 & 31 & 2.79 & $\mathbf{N}$ \\
\hline & $3 / 12 / 92$ & $<1$ & $<1$ & 0 & \\
\hline \multirow[t]{2}{*}{ USGS 17} & $3 / 13 / 91$ & 1 & 1 & .00 & \\
\hline & $6 / 11 / 93$ & $<1$ & $<1$ & 0 & \\
\hline \multirow[t]{3}{*}{ USGS 97} & $6 / 07 / 90$ & 1 & 1 & .00 & \\
\hline & $12 / 07 / 90$ & $<1$ & 1 & 0 & \\
\hline & $6 / 07 / 91$ & $<1$ & $<1$ & 0 & \\
\hline \multirow[t]{2}{*}{ USGS 98} & $7 / 30 / 90$ & $<1$ & $<1$ & 0 & \\
\hline & $9 / 21 / 92$ & $<1$ & $<1$ & 0 & \\
\hline \multirow[t]{2}{*}{ USGS 99} & $10 / 03 / 90$ & 1 & 3 & .56 & \\
\hline & $6 / 16 / 92$ & $<1$ & 1 & .29 & \\
\hline \multirow[t]{2}{*}{ USGS 102} & $12 / 10 / 90$ & 2 & 1 & .28 & \\
\hline & $12 / 09 / 92$ & 2 & 2 & .00 & \\
\hline USGS 122 & $10 / 15 / 91$ & $* * 10$ & $* *<10$ & 0 & \\
\hline
\end{tabular}


Table 30. Comparison of results of replicate pairs of samples from the Idaho National Engineering Laboratory analyzed for selenium by the National Water Quality Laboratory

[Site identifier: see figures 1-3 for location of sites. QA: quality-assurance replicate sample. Z-value: see section on Statistical Comparisons of Replicate Pairs of Samples for explanation. Remark: the results of replicate pairs are statistically equivalent. Abbreviations: $\mu \mathrm{g} / \mathrm{L}$, microgram per liter. Symbols: $<$, the result was less than the indicated reporting level; **, the water sample was analyzed for dissolved selenium, rather than total recoverable selenium]

\begin{tabular}{|c|c|c|c|c|c|}
\hline Site identifier & Date sampled & $\begin{array}{l}\text { Selenium } \\
(\mu \mathrm{g} / \mathrm{L})\end{array}$ & $\begin{array}{l}\text { Selenium QA } \\
(\mu \mathrm{g} / \mathrm{L})\end{array}$ & Z-value & Remark \\
\hline NRF-2 & $3 / 21 / 90$ & 1 & 2 & 0.79 & \\
\hline$N R F-4$ & $2 / 07 / 91$ & 2 & 2 & .00 & \\
\hline NRF-6 & $3 / 10 / 92$ & 2 & 2 & .00 & \\
\hline NRF-7 & $1 / 08 / 92$ & $<1$ & 1 & 0 & \\
\hline WSINEL1 & $12 / 07 / 90$ & 2 & 2 & .00 & \\
\hline USGS 12 & $6 / 15 / 90$ & 2 & 2 & .00 & \\
\hline USGS 15 & $8 / 06 / 90$ & 1 & 1 & .00 & \\
\hline USGS 44 & $10 / 26 / 90$ & $* * 2$ & $* * 2$ & .00 & \\
\hline \multirow[t]{2}{*}{ USGS 97} & $6 / 07 / 90$ & 2 & 2 & .00 & \\
\hline & $12 / 07 / 90$ & 1 & 1 & .00 & \\
\hline USGS 98 & $7 / 30 / 90$ & 1 & 1 & .00 & \\
\hline USGS 99 & $10 / 03 / 90$ & 1 & 1 & .00 & \\
\hline USGS 102 & $12 / 10 / 90$ & 1 & 1 & .00 & \\
\hline USGS 122 & $10 / 15 / 91$ & $* * 1$ & $* *<1$ & 0 & \\
\hline
\end{tabular}


Table 31. Comparison of results of replicate pairs of samples from the Idaho National Engineering Laboratory analyzed for silver by the National Water Quality Laboratory

[Site identifier: see figures 1-3 for location of sites. QA: quality-assurance replicate sample. Z-value: see section on Statistical Comparisons of Replicate Pairs of Samples for explanation. Remark: the results of replicate pairs are statistically equivalent. Abbreviations: $\mu \mathrm{g} / \mathrm{L}$, microgram per liter. Symbols: $<$, the result was less than the indicated reporting level; **, the water sample was analyzed for dissolved silver, rather than total recoverable silver]

\begin{tabular}{|c|c|c|c|c|c|}
\hline Site identifier & Date sampled & $\begin{array}{l}\text { Silver } \\
(\mu \mathrm{g} / \mathrm{L})\end{array}$ & $\begin{array}{c}\text { Silver QA } \\
(\mu \mathrm{g} / \mathrm{L})\end{array}$ & Z-value & Remark \\
\hline NRF-1 & $9 / 09 / 91$ & $<1$ & $<1$ & 0 & \\
\hline \multirow{3}{*}{ NRF-2 } & $3 / 21 / 90$ & $<1$ & $<1$ & 0 & \\
\hline & $3 / 05 / 91$ & $<1$ & $<1$ & 0 & \\
\hline & $9 / 15 / 93$ & $<1$ & $<1$ & 0 & \\
\hline \multirow[t]{2}{*}{ NRF-3 } & $6 / 17 / 91$ & $<1$ & $<1$ & 0 & \\
\hline & $12 / 03 / 92$ & $<1$ & $<1$ & 0 & \\
\hline \multirow[t]{2}{*}{ NRF-4 } & $2 / 07 / 91$ & $<1$ & $<1$ & 0 & \\
\hline & $4 / 07 / 93$ & $<1$ & $<1$ & 0 & \\
\hline NRF-6 & $3 / 10 / 92$ & $<1$ & $<1$ & 0 & \\
\hline NRF-7 & $1 / 08 / 92$ & $<1$ & $<1$ & 0 & \\
\hline WSINEL1 & $12 / 03 / 91$ & $<1$ & $<1$ & 0 & \\
\hline \multirow[t]{3}{*}{ USGS 12} & $6 / 15 / 90$ & $<1$ & $<1$ & 0 & \\
\hline & $9 / 06 / 91$ & $<1$ & $<1$ & 0 & \\
\hline & $11 / 05 / 93$ & $<1$ & $<1$ & 0 & \\
\hline \multirow[t]{2}{*}{ USGS 15} & $8 / 06 / 90$ & $<1$ & $<1$ & 0 & \\
\hline & $3 / 12 / 92$ & $<1$ & $<1$ & 0 & \\
\hline \multirow[t]{2}{*}{ USGS 17} & $3 / 13 / 91$ & $<1$ & $<1$ & 0 & \\
\hline & $6 / 11 / 93$ & $<1$ & $<1$ & 0 & \\
\hline USGS 44 & $10 / 26 / 90$ & $* *<1$ & $* *<1$ & 0 & \\
\hline \multirow[t]{4}{*}{ USGS 97} & $6 / 07 / 90$ & $<1$ & $<1$ & 0 & \\
\hline & $12 / 07 / 90$ & $<1$ & $<1$ & 0 & \\
\hline & $6 / 07 / 91$ & $<1$ & $<1$ & 0 & \\
\hline & $11 / 04 / 93$ & $<1$ & $<1$ & 0 & \\
\hline \multirow[t]{2}{*}{ USGS 98} & $7 / 30 / 90$ & $<1$ & $<1$ & 0 & \\
\hline & $9 / 21 / 92$ & $<1$ & $<1$ & 0 & \\
\hline \multirow[t]{2}{*}{ USGS 99} & $10 / 03 / 90$ & $<1$ & $<1$ & 0 & \\
\hline & $6 / 16 / 92$ & $<1$ & $<1$ & 0 & \\
\hline \multirow[t]{2}{*}{ USGS 102} & $12 / 10 / 90$ & $<1$ & $<1$ & 0 & \\
\hline & $12 / 09 / 92$ & $<1$ & $<1$ & 0 & \\
\hline \multirow[t]{2}{*}{ USGS 122} & $10 / 15 / 91$ & $* *<1$ & $* *<1$ & 0 & \\
\hline & $12 / 07 / 90$ & $<1$ & $<1$ & 0 & \\
\hline
\end{tabular}


Table 32. Comparison of results of replicate pairs of samples from the Idaho National Engineering Laboratory analyzed for zinc by the National Water Quality Laboratory

[Site identifier: see figures 1-3 for location of sites. QA: quality-assurance replicate sample. Z-value: see section on Statistical Comparisons of Replicate Pairs of Samples for explanation. Remark: the results of replicate pairs are statistically equivalent. Abbreviations: $\mu \mathrm{g} / \mathrm{L}$, microgram per liter. Symbols: $<$, the result was less than the indicated reporting level; ${ }^{* *}$, the water sample was analyzed for dissolved zinc, rather than total recoverable zinc]

\begin{tabular}{lccccc}
\hline Site identifier & Date sampled & $\begin{array}{c}\text { Zinc QA } \\
(\mu \mathrm{g} / \mathrm{L})\end{array}$ & $\begin{array}{c}\text { Zinc } \\
(\mu \mathrm{g} / \mathrm{L})\end{array}$ & Z-value & Remark \\
\hline NRF-2 & $3 / 21 / 90$ & $<10$ & $<10$ & 0 \\
NRF-4 & $2 / 07 / 91$ & $<10$ & 10 & 0 \\
NRF-6 & $3 / 10 / 92$ & 10 & 20 & .94 \\
NRF-7 & $1 / 08 / 92$ & 40 & 30 & .94 \\
WSINEL1 & $12 / 07 / 90$ & 120 & 130 & .68 \\
USGS 12 & $6 / 15 / 90$ & 10 & 10 & .00 \\
USGS 15 & $8 / 06 / 90$ & 50 & 30 & 1.89 \\
USGS 97 & $6 / 07 / 90$ & 80 & 80 & .00 \\
& $12 / 07 / 90$ & 110 & 120 & .71 \\
USGS 98 & $7 / 30 / 90$ & 110 & 120 & .71 \\
USGS 99 & $10 / 03 / 90$ & 80 & 90 & .83 \\
USGS 102 & $12 / 10 / 90$ & $<10$ & $<10$ & 0 \\
USGS 122 & $10 / 15 / 91$ & $* * 5$ & $* * 10$ & .47 \\
\hline
\end{tabular}


Table 33. Comparison of the results and standard deviations of replicate pairs of samples from the Idaho National Engineering Laboratory analyzed for gross alpha radioactivity, dissolved in water, as thorium-230 by the National Water Quality Laboratory

[Site identifier: see figures 1-3 for location of sites. QA: quality-assurance replicate sample. Z-value: see section on Statistical Comparisons of Replicate Pairs of Samples for explanation. Abbreviations: pCi/L, picocurie per liter; N, the analytical results are not in statistical agreement]

\begin{tabular}{|c|c|c|c|c|c|}
\hline Site identifier & Date sampled & $\begin{array}{c}\text { Gross alpha, } \\
\text { dissolved, as } \\
\text { thorium-230 } \\
\text { (pCi/L) }\end{array}$ & $\begin{array}{l}\text { Gross alpha, } \\
\text { dissolved, as } \\
\text { thorium-230 } \\
\mathrm{QA}(\mathrm{pCi} / \mathrm{L})\end{array}$ & $Z$-value & Remark \\
\hline NRF-1 & $9 / 09 / 91$ & $2.33 \pm 0.784$ & $2.19 \pm 0.753$ & 0.26 & \\
\hline \multirow[t]{3}{*}{ NRF-2 } & $3 / 21 / 90$ & $2.86 \pm 0.899$ & $2.75 \pm 0.942$ & .17 & \\
\hline & $3 / 05 / 91$ & $2.84 \pm 0.894$ & $3.02 \pm 0.881$ & .29 & \\
\hline & $9 / 15 / 93$ & $3.38 \pm 1.93$ & $4.42 \pm 2.31$ & .69 & \\
\hline \multirow[t]{2}{*}{ NRF-3 } & $6 / 17 / 91$ & $3.04 \pm 0.873$ & $2.26 \pm 0.781$ & 1.33 & \\
\hline & $12 / 03 / 92$ & $3.69 \pm 1.75$ & $3.95 \pm 2.18$ & .19 & \\
\hline \multirow[t]{2}{*}{ NRF-4 } & $2 / 07 / 91$ & $2.72 \pm 0.818$ & $3.15 \pm 0.915$ & .70 & \\
\hline & 4/07/93 & $2.49 \pm 0.862$ & $2.10 \pm 0.873$ & .64 & \\
\hline NRF-6 & $3 / 10 / 92$ & $3.35 \pm 3.07$ & $1.97 \pm 0.705$ & .88 & \\
\hline NRF-7 & $1 / 08 / 92$ & $1.28 \pm 0.587$ & $1.36 \pm 0.586$ & .19 & \\
\hline \multirow[t]{2}{*}{ WSINEL1 } & $12 / 07 / 90$ & $2.23 \pm 0.778$ & $2.67 \pm 0.827$ & .78 & \\
\hline & $12 / 03 / 91$ & $1.69 \pm 0.677$ & $2.29 \pm 0.770$ & 1.17 & \\
\hline \multirow[t]{3}{*}{ USGS 12} & $6 / 15 / 90$ & $1.47 \pm 0.648$ & $3.56 \pm 1.03$ & 3.44 & $\mathbf{N}$ \\
\hline & $9 / 06 / 91$ & $2.23 \pm 0.778$ & $2.09 \pm 0.745$ & .26 & \\
\hline & $11 / 05 / 93$ & $3.33 \pm 1.83$ & $3.59 \pm 1.75$ & .21 & \\
\hline \multirow[t]{2}{*}{ USGS 15} & $8 / 06 / 90$ & $2.44 \pm 0.814$ & $1.51 \pm 0.673$ & 1.76 & \\
\hline & $3 / 12 / 92$ & $1.37 \pm 0.624$ & $1.74 \pm 0.669$ & .81 & \\
\hline \multirow[t]{2}{*}{ USGS 17} & $3 / 13 / 91$ & $1.26 \pm 0.586$ & $1.35 \pm 0.591$ & .22 & \\
\hline & $6 / 11 / 93$ & $1.38 \pm 0.827$ & $2.08 \pm 1.06$ & 1.04 & \\
\hline \multirow[t]{4}{*}{ USGS 97} & $6 / 07 / 90$ & $2.80 \pm 0.848$ & $2.60 \pm 0.842$ & .33 & \\
\hline & $12 / 07 / 90$ & $1.82 \pm 0.682$ & $2.76 \pm 0.868$ & 1.70 & \\
\hline & $6 / 07 / 91$ & $3.47 \pm 0.965$ & $3.13 \pm 0.906$ & .51 & \\
\hline & $11 / 04 / 93$ & $1.70 \pm 1.31$ & $3.79 \pm 1.19$ & 2.36 & $N$ \\
\hline \multirow[t]{2}{*}{ USGS 98} & $7 / 30 / 90$ & $2.16 \pm 0.802$ & $1.81 \pm 0.718$ & .65 & \\
\hline & $9 / 21 / 92$ & $1.02 \pm 0.485$ & $2.13 \pm 0.754$ & 2.48 & $\mathbf{N}$ \\
\hline \multirow[t]{2}{*}{ USGS 99} & $10 / 03 / 90$ & $2.30 \pm 0.781$ & $2.71 \pm 0.850$ & .71 & \\
\hline & $6 / 16 / 92$ & $1.27 \pm 0.560$ & $1.28 \pm 0.609$ & .02 & \\
\hline \multirow[t]{2}{*}{ USGS 102} & $12 / 10 / 90$ & $2.63 \pm 0.830$ & $2.97 \pm 0.887$ & .56 & \\
\hline & $12 / 09 / 92$ & $2.15 \pm 1.42$ & $3.48 \pm 1.75$ & 1.18 & \\
\hline
\end{tabular}


Table 34. Comparison of the results and standard deviations of replicate pairs of samples from the Idaho National Engineering Laboratory analyzed for gross alpha radioactivity, suspended in water, as thorium-230 by the National Water Quality Laboratory

[Site identifier: see figures 1-3 for location of sites. QA: quality-assurance replicate sample. Z-value: see section on Statistical Comparisons of Replicate Pairs of Samples for explanation. Abbreviations: pCi/L, picocurie per liter; N, the analytical results are not in statistical agreement]

\begin{tabular}{|c|c|c|c|c|c|}
\hline Site identifier & Date sampled & $\begin{array}{l}\text { Gross alpha, } \\
\text { suspended, } \\
\text { as thorium-230 } \\
(\mathrm{pCi} / \mathrm{L})\end{array}$ & $\begin{array}{l}\text { Gross alpha, } \\
\text { suspended, } \\
\text { as thorium-230 } \\
\text { QA (pCi/L) }\end{array}$ & $\mathrm{Z}$-value & Remark \\
\hline NRF-1 & $9 / 09 / 91$ & $-0.064 \pm 0.125$ & $-0.016 \pm 0.169$ & 0.46 & \\
\hline \multirow[t]{2}{*}{ NRF-2 } & $3 / 21 / 90$ & $.143 \pm 0.242$ & $.020 \pm 0.165$ & .84 & \\
\hline & $3 / 05 / 91$ & $.291 \pm 0.327$ & $-.066 \pm 0.129$ & 2.03 & $\mathbf{N}$ \\
\hline \multirow[t]{2}{*}{ NRF-3 } & $6 / 17 / 91$ & $.047 \pm 0.144$ & $-.015 \pm 0.165$ & .57 & \\
\hline & $12 / 03 / 92$ & $-.200 \pm 0.192$ & $.066 \pm 0.184$ & 2.00 & $\mathbf{N}$ \\
\hline \multirow[t]{2}{*}{ NRF-4 } & $2 / 07 / 91$ & $.021 \pm 0.126$ & $.122 \pm 0.224$ & .79 & \\
\hline & $4 / 07 / 93$ & $.065 \pm 0.149$ & $.166 \pm 0.211$ & .78 & \\
\hline NRF-6 & $3 / 10 / 92$ & $-.005 \pm 0.091$ & $.116 \pm 0.213$ & 1.04 & \\
\hline NRF-7 & $1 / 08 / 92$ & $.012 \div 0.210$ & $.065 \pm 0.264$ & .31 & \\
\hline \multirow[t]{2}{*}{ WSINEL1 } & $12 / 07 / 90$ & $-.168 \pm 0.206$ & $.025 \pm 0.233$ & 1.24 & \\
\hline & $12 / 03 / 91$ & $.217 \pm 0.288$ & $-.065 \pm 0.253$ & 1.47 & \\
\hline \multirow[t]{2}{*}{ USGS 12} & $6 / 15 / 90$ & $.005 \pm 0.203$ & $.031 \pm 0.220$ & .17 & \\
\hline & $9 / 06 / 91$ & $.022 \pm 0.130$ & $.098 \pm 0.179$ & .69 & \\
\hline \multirow[t]{2}{*}{ USGS 15} & $8 / 06 / 90$ & $2.20 \pm 1.42$ & $7.28 \pm 5.24$ & 1.87 & \\
\hline & $3 / 12 / 92$ & $.035 \pm 0.191$ & $-.005 \pm 0.095$ & .38 & \\
\hline USGS 17 & $3 / 13 / 91$ & $.056 \pm 0.227$ & $.197 \pm 0.234$ & .86 & \\
\hline \multirow[t]{3}{*}{ USGS 97} & $6 / 07 / 90$ & $.022 \pm 0.274$ & $.000 \pm 0.292$ & .11 & \\
\hline & $12 / 07 / 90$ & $-.044 \pm 0.170$ & $.046 \pm 0.142$ & .81 & \\
\hline & $6 / 07 / 91$ & $.097 \pm 0.171$ & $.020 \pm 0.119$ & .74 & \\
\hline \multirow[t]{2}{*}{ USGS 98} & $7 / 30 / 90$ & $.020 \pm 0.258$ & $.000 \pm 0.428$ & .08 & \\
\hline & $9 / 21 / 92$ & $.056 \pm 0.228$ & $.136 \pm 0.243$ & .48 & \\
\hline \multirow[t]{2}{*}{ USGS 99} & $10 / 03 / 90$ & $-.005 \pm 0.247$ & $.049 \pm 0.282$ & .29 & \\
\hline & $6 / 16 / 92$ & $-.103 \pm 0.176$ & $.232 \pm 0.328$ & 1.80 & \\
\hline \multirow[t]{2}{*}{ USGS 102} & $12 / 10 / 90$ & $.005 \pm 0.204$ & $-.144 \pm 0.220$ & .99 & \\
\hline & $12 / 09 / 92$ & $.117 \pm 0.213$ & $.055 \pm 0.225$ & .40 & \\
\hline
\end{tabular}


Table 35. Comparison of the results and standard deviations of replicate pairs of samples from the Idaho National Engineering Laboratory analyzed for gross alpha radioactivity, dissolved in water, as natural uranium by the National Water Quality Laboratory

[Site identifier: see figures 1-3 for location of sites. QA: quality-assurance replicate sample. Z-value: see section on Statistical Comparisons of Replicate Pairs of Samples for explanation. Abbreviations: $\mu \mathrm{g} / \mathrm{L}$, microgram per liter; $N$, the analytical results are not in statistical agreement]

\begin{tabular}{|c|c|c|c|c|c|}
\hline Site identifier & $\begin{array}{c}\text { Date } \\
\text { sampled }\end{array}$ & $\begin{array}{l}\text { Gross alpha, dissolved, } \\
\text { as natural uranium } \\
(\mu \mathrm{g} / \mathrm{L})\end{array}$ & $\begin{array}{c}\text { Gross alpha, dissolved, } \\
\text { as natural uranium QA } \\
(\mu \mathrm{g} / \mathrm{L})\end{array}$ & Z-value & Remark \\
\hline NRF-1 & $9 / 09 / 91$ & $3.33 \pm 1.13$ & $3.12 \pm 1.05$ & 0.27 & \\
\hline \multirow[t]{3}{*}{ NRF-2 } & $3 / 21 / 90$ & $4.25 \pm 1.31$ & $4.47 \pm 1.44$ & .23 & \\
\hline & $3 / 05 / 91$ & $2.81 \pm 0.884$ & $3.01 \pm 0.871$ & .32 & \\
\hline & $9 / 15 / 93$ & $4.56 \pm 2.61$ & $5.73 \pm 3.01$ & .59 & \\
\hline \multirow[t]{2}{*}{ NRF-3 } & $6 / 17 / 91$ & $4.38 \pm 1.27$ & $3.66 \pm 1.19$ & .83 & \\
\hline & $12 / 03 / 92$ & $5.13 \pm 2.45$ & $5.12 \pm 2.84$ & .01 & \\
\hline \multirow[t]{2}{*}{ NRF-4 } & $2 / 07 / 91$ & $3.95 \pm 1.20$ & $4.40 \pm 1.28$ & .51 & \\
\hline & 4/07/93 & $3.56 \pm 1.22$ & $3.03 \pm 1.25$ & .61 & \\
\hline NRF-6 & $3 / 10 / 92$ & $4.35 \pm 3.99$ & $2.88 \pm 1.02$ & .71 & \\
\hline NRF-7 & $1 / 08 / 92$ & $1.85 \pm 0.844$ & $1.98 \pm 0.843$ & .22 & \\
\hline \multirow[t]{2}{*}{ WSINEL1 } & $12 / 07 / 90$ & $3.58 \pm 1.19$ & $3.58 \pm 1.19$ & .00 & \\
\hline & $12 / 03 / 91$ & $2.72 \pm 1.05$ & $3.33 \pm 1.10$ & .80 & \\
\hline \multirow[t]{3}{*}{ USGS 12} & $6 / 15 / 90$ & $2.08 \pm 0.196$ & $5.11 \pm 1.46$ & 4.11 & $\mathbf{N}$ \\
\hline & 9/06/91 & $3.16 \pm 1.10$ & $3.03 \pm 1.07$ & .17 & \\
\hline & $11 / 05 / 93$ & $4.50 \pm 2.48$ & $5.15 \pm 2.51$ & .73 & \\
\hline \multirow[t]{2}{*}{ USGS 15} & $8 / 06 / 90$ & $3.48 \pm 1.15$ & $2.41 \pm 1.04$ & 1.38 & \\
\hline & $3 / 12 / 92$ & $1.87 \pm 0.853$ & $2.48 \pm 0.949$ & .96 & \\
\hline \multirow[t]{2}{*}{ USGS 17} & $3 / 13 / 91$ & $1.26 \pm 0.583$ & $1.51 \pm 0.637$ & .58 & \\
\hline & $6 / 11 / 93$ & $1.91 \pm 1.15$ & $2.81 \pm 1.44$ & .98 & \\
\hline \multirow[t]{4}{*}{ USGS 97} & $6 / 07 / 90$ & $4.05 \pm 1.21$ & $4.22 \pm 1.28$ & .19 & \\
\hline & $12 / 07 / 90$ & $2.64 \pm 0.986$ & $3.86 \pm 1.21$ & 1.56 & \\
\hline & $6 / 07 / 91$ & $4.96 \pm 1.37$ & $4.50 \pm 1.29$ & .49 & \\
\hline & $11 / 04 / 93$ & $2.29 \pm 1.77$ & $5.31 \pm 2.69$ & 1.88 & \\
\hline \multirow[t]{2}{*}{ USGS 98} & $7 / 30 / 90$ & $3.44 \pm 1.23$ & $2.60 \pm 1.02$ & 1.05 & \\
\hline & $09 / 21 / 92$ & $1.49 \pm 0.711$ & $2.97 \pm 1.05$ & 2.33 & $\mathrm{~N}$ \\
\hline \multirow[t]{2}{*}{ USGS 99} & $10 / 03 / 90$ & $.442 \pm 0.346$ & $.449 \pm 0.414$ & .03 & \\
\hline & $6 / 16 / 92$ & $1.82 \pm 0.806$ & $1.76 \pm 0.838$ & .10 & \\
\hline \multirow[t]{2}{*}{ USGS 102} & $12 / 10 / 90$ & $3.83 \pm 1.19$ & $4.27 \pm 1.27$ & .51 & \\
\hline & $12 / 09 / 92$ & $3.04 \pm 2.01$ & $4.92 \pm 2.49$ & 1.17 & \\
\hline
\end{tabular}


Table 36. Comparison of the results and standard deviations of replicate pairs of samples from the Idaho National Engineering Laboratory analyzed for gross alpha radioactivity, suspended in water, as natural uranium by the National Water Quality Laboratory

Site identifier: see figures 1-3 for location of sites. QA: quality-assurance replicate sample. Z-value: see section on Statistical Comparisons of Replicate Pairs of Samples for explanation. Abbreviations: $\mu \mathrm{g} / \mathrm{L}$, microgram per liter; N, the analytical results are not in statistical agreement]

\begin{tabular}{|c|c|c|c|c|c|}
\hline Site identifier & $\begin{array}{c}\text { Date } \\
\text { sampled }\end{array}$ & $\begin{array}{c}\text { Gross alpha, suspended, } \\
\text { as natural uranium } \\
(\mu \mathrm{g} / \mathrm{L})\end{array}$ & $\begin{array}{c}\text { Gross alpha, suspended, } \\
\text { as natural uranium QA } \\
(\mu \mathrm{g} / \mathrm{L})\end{array}$ & $\mathrm{Z}$-value & Remark \\
\hline NRF-1 & $9 / 09 / 91$ & $-0.119 \pm 0.231$ & $-0.028 \pm 0.295$ & 0.49 & \\
\hline \multirow[t]{2}{*}{ NRF-2 } & $3 / 21 / 90$ & $.273 \pm 0.459$ & $.038 \pm 0.311$ & .85 & \\
\hline & $3 / 05 / 91$ & $.539 \pm 0.595$ & $-.122 \pm 0.236$ & 2.07 & $\mathbf{N}$ \\
\hline \multirow[t]{2}{*}{ NRF-3 } & $6 / 17 / 91$ & $.083 \pm 0.251$ & $-.028 \pm 0.303$ & .56 & \\
\hline & $12 / 03 / 92$ & $-.348 \pm 0.329$ & $.122 \pm 0.336$ & 2.00 & $\mathrm{~N}$ \\
\hline \multirow[t]{2}{*}{ NRF-4 } & $2 / 07 / 91$ & $.037 \pm 0.216$ & $.209 \pm 0.374$ & .80 & \\
\hline & $4 / 07 / 93$ & $.120 \pm 0.271$ & $.217 \pm 0.389$ & .41 & \\
\hline NRF-6 & $3 / 10 / 92$ & $-.009 \pm 0.171$ & $.216 \pm 0.387$ & 1.06 & \\
\hline NRF-7 & $1 / 08 / 92$ & $.017 \pm 0.300$ & $.094 \pm 0.382$ & .32 & \\
\hline \multirow[t]{2}{*}{ WSINEL1 } & $12 / 07 / 90$ & $-.293 \pm 0.345$ & $.048 \pm 0.440$ & 1.22 & \\
\hline & $12 / 03 / 91$ & $.388 \pm 0.494$ & $-.118 \pm 0.461$ & 1.50 & \\
\hline \multirow[t]{2}{*}{ USGS 12} & $6 / 15 / 90$ & $.009 \pm 0.372$ & $.058 \pm 0.406$ & .18 & \\
\hline & $9 / 06 / 91$ & $.034 \pm 0.198$ & $.175 \pm 0.313$ & .76 & \\
\hline \multirow[t]{2}{*}{ USGS 15} & $8 / 06 / 90$ & $1.76 \pm 1.12$ & $9.10 \pm 6.01$ & 2.40 & $\mathbf{N}$ \\
\hline & $3 / 12 / 92$ & $.066 \pm 0.357$ & $-.009 \pm 0.174$ & .38 & \\
\hline USGS 17 & $3 / 13 / 91$ & $.170 \pm 0.433$ & $.365 \pm 0.415$ & .65 & \\
\hline \multirow[t]{3}{*}{ USGS 97} & $6 / 07 / 90$ & $.036 \pm 0.447$ & $.000 \pm 0.390$ & .12 & \\
\hline & $12 / 07 / 90$ & $-.082 \pm 0.314$ & $.084 \pm 0.253$ & .82 & \\
\hline & $6 / 07 / 91$ & $.185 \pm 0.227$ & $.039 \pm 0.330$ & .73 & \\
\hline \multirow[t]{2}{*}{ USGS 98} & $7 / 30 / 90$ & $.037 \pm 0.465$ & $.000 \pm 0.428$ & .12 & \\
\hline & $9 / 21 / 92$ & $.107 \pm 0.433$ & $.255 \pm 0.447$ & .48 & \\
\hline \multirow[t]{2}{*}{ USGS 99} & $10 / 03 / 90$ & $-.008 \pm 0.448$ & $.081 \pm 0.464$ & .28 & \\
\hline & $6 / 16 / 92$ & $-.185 \pm 0.310$ & $.418 \pm 0.569$ & 1.86 & \\
\hline \multirow[t]{2}{*}{ USGS 102} & $12 / 10 / 90$ & $.009 \pm 0.355$ & $-.245 \pm 0.366$ & 1.00 & \\
\hline & $12 / 09 / 92$ & $.215 \pm 0.385$ & $.104 \pm 0.420$ & .39 & \\
\hline
\end{tabular}


Table 37. Comparison of the results and standard deviations of replicate pairs of samples from the Idaho National Engineering Laboratory analyzed for gross alpha radioactivity by the Radiological and Environmental Sciences Laboratory

Site identifier: see figures 1-3 for location of sites. QA: quality-assurance replicate sample. Z-value: see section on Statistical Comparisons of Replicate Pairs of Samples for explanation. Remark: the results of replicate pairs are statistically equivalent. Abbreviations: $\mathrm{pCi} / \mathrm{L}$, picocurie per liter]

\begin{tabular}{lccccc}
\hline Site identifier & Date sampled & $\begin{array}{c}\text { Gross alpha } \\
(\mathrm{pCi} / \mathrm{L})\end{array}$ & $\begin{array}{c}\text { Gross alpha QA } \\
(\mathrm{pCi} / \mathrm{L})\end{array}$ & Z-value & Remark \\
\hline Big Lost River & $10 / 09 / 91$ & $1.4 \pm 1.1$ & $2.8 \pm 1.3$ & 0.82 \\
Cerro Grande & $10 / 18 / 90$ & $13 \pm 6$ & $13 \pm 6$ & .00 \\
USGS 8 & $4 / 03 / 91$ & $.7 \pm 0.8$ & $.0 \pm 0.8$ & .62 \\
USGS 11 & $10 / 08 / 91$ & $1.0 \pm 1.1$ & $1.0 \pm 1.1$ & .00 \\
USGS 14 & $10 / 01 / 92$ & $1.7 \pm 0.9$ & $3.1 \pm 1.2$ & .93 \\
& $4 / 16 / 93$ & $2.1 \pm 1.0$ & $2.1 \pm 1.0$ & .00 \\
\hline
\end{tabular}


Table 38. Comparison of the results and standard deviations of replicate pairs of samples from the Idaho National Engineering Laboratory analyzed for gross beta radioactivity, dissolved in water, as cesium-137 by the National Water Quality Laboratory

[Site identifier: see figures 1-3 for location of sites. QA: quality-assurance replicate sample. Z-value: see section on Statistical Comparisons of Replicate Pairs of Samples for explanation. Abbreviations: pCi/L, picocurie per liter; N, the analytical results are not in statistical agreement]

\begin{tabular}{|c|c|c|c|c|c|}
\hline Site identifier & Date sampled & $\begin{array}{l}\text { Gross beta, dissolved, } \\
\text { as cesium-137 } \\
(\mathrm{pCi} / \mathrm{L})\end{array}$ & $\begin{array}{c}\text { Gross beta, dissolved, } \\
\text { as cesium-137 QA } \\
(\mathrm{pCi} / \mathrm{L})\end{array}$ & Z-value & Remark \\
\hline NRF-1 & $9 / 09 / 91$ & $3.33 \pm 1.38$ & $3.59 \pm 1.35$ & 0.27 & \\
\hline \multirow[t]{3}{*}{ NRF-2 } & $3 / 21 / 90$ & $4.69 \pm 1.37$ & $3.81 \pm 1.31$ & .93 & \\
\hline & $3 / 05 / 91$ & $3.86 \pm 1.29$ & $3.83 \pm 1.28$ & .03 & \\
\hline & $9 / 15 / 93$ & $4.89 \pm 1.31$ & $4.83 \pm 1.34$ & .06 & \\
\hline \multirow[t]{2}{*}{ NRF-3 } & $6 / 17 / 91$ & $2.68 \pm 1.01$ & $2.94 \pm 1.08$ & .35 & \\
\hline & $12 / 03 / 92$ & $3.14 \pm 1.02$ & $2.74 \pm 0.994$ & .56 & \\
\hline \multirow[t]{2}{*}{ NRF-4 } & $2 / 07 / 91$ & $3.37 \pm 1.15$ & $4.56 \pm 1.37$ & 1.33 & \\
\hline & $4 / 07 / 93$ & $3.56 \pm 1.12$ & $5.00 \pm 1.35$ & 1.64 & \\
\hline NRF-6 & $3 / 10 / 92$ & $6.87 \pm 1.95$ & $5.87 \pm 1.87$ & .74 & \\
\hline NRF-7 & $1 / 08 / 92$ & $3.34 \pm 1.08$ & $3.48 \pm 1.07$ & .18 & \\
\hline \multirow[t]{2}{*}{ WSINEL1 } & $12 / 07 / 90$ & $5.72 \pm 1.60$ & $5.22 \pm 1.52$ & .45 & \\
\hline & $12 / 03 / 91$ & $4.99 \pm 1.66$ & $5.44 \pm 1.72$ & .38 & \\
\hline \multirow[t]{3}{*}{ USGS 12} & $6 / 15 / 90$ & $4.79 \pm 1.46$ & $3.62 \pm 1.23$ & 1.23 & \\
\hline & $9 / 06 / 91$ & $2.95 \pm 1.18$ & $2.27 \pm 1.14$ & .83 & \\
\hline & $11 / 05 / 93$ & $3.79 \pm 2.05$ & $3.99 \pm 1.16$ & .17 & \\
\hline \multirow[t]{2}{*}{ USGS 15} & $8 / 06 / 90$ & $3.91 \pm 1.32$ & $4.38 \pm 1.76$ & .43 & \\
\hline & $3 / 12 / 92$ & $1.98 \pm 0.843$ & $1.89 \pm 0.821$ & .15 & \\
\hline \multirow[t]{2}{*}{ USGS 17} & $3 / 13 / 91$ & $2.86 \pm 1.02$ & $3.02 \pm 1.00$ & .22 & \\
\hline & $6 / 11 / 93$ & $2.70 \pm 1.01$ & $3.08 \pm 1.04$ & .52 & \\
\hline \multirow[t]{4}{*}{ USGS 97} & $6 / 07 / 90$ & $3.58 \pm 1.31$ & $3.37 \pm 1.29$ & .23 & \\
\hline & $12 / 07 / 90$ & $4.66 \pm 1.29$ & $3.43 \pm 1.11$ & 1.45 & \\
\hline & $6 / 07 / 91$ & $4.25 \pm 1.30$ & $3.09 \pm 1.22$ & 1.30 & \\
\hline & $11 / 04 / 93$ & $4.15 \pm 1.15$ & $3.53 \pm 1.17$ & .76 & \\
\hline \multirow[t]{2}{*}{ USGS 98} & $7 / 30 / 90$ & $2.92 \pm 1.03$ & $3.59 \pm 1.03$ & .92 & \\
\hline & $9 / 21 / 92$ & $3.76 \pm 1.18$ & $3.63 \pm 1.06$ & .16 & \\
\hline \multirow[t]{2}{*}{ USGS 99} & $10 / 03 / 90$ & $2.33 \pm 0.956$ & $4.28 \pm 1.23$ & 2.50 & $\mathbf{N}$ \\
\hline & $6 / 16 / 92$ & $2.25 \pm 0.863$ & $2.43 \pm 0.907$ & .29 & \\
\hline \multirow[t]{2}{*}{ USGS 102} & $12 / 10 / 90$ & $3.56 \pm 1.15$ & $4.18 \pm 1.24$ & .73 & \\
\hline & $12 / 09 / 92$ & $2.88 \pm 0.980$ & $3.25 \pm 1.02$ & .52 & \\
\hline
\end{tabular}


Table 39. Comparison of the results and standard deviations of replicate pairs of samples from the Idaho National Engineering Laboratory analyzed for gross beta radioactivity, suspended in water, as cesium-137 by the National Water Quality Laboratory

[Site identifier: see figures 1-3 for location of sites. QA: quality-assurance replicate sample. Z-value: see section on Statistical Comparisons of Replicate Pairs of Samples for explanation. Abbreviations: pCi/L, picocurie per liter; N, the analytical results are not in statistical agreement]

\begin{tabular}{|c|c|c|c|c|c|}
\hline Site identifier & Date sampled & $\begin{array}{l}\text { Gross beta, suspended, } \\
\text { as cesium- } 137 \\
(\mathrm{pCi} / \mathrm{L})\end{array}$ & $\begin{array}{c}\text { Gross beta, suspended, } \\
\text { as cesium-137 QA } \\
(\mathrm{pCi} / \mathrm{L})\end{array}$ & Z-value & Remark \\
\hline NRF-1 & $9 / 09 / 91$ & $0.439 \pm 0.578$ & $0.184 \pm 0.546$ & 0.64 & \\
\hline \multirow[t]{2}{*}{ NRF-2 } & $3 / 21 / 90$ & $.311 \pm 0.505$ & $-.144 \pm 0.552$ & 1.22 & \\
\hline & $3 / 05 / 91$ & $.731 \pm 0.593$ & $.467 \pm 0.521$ & .67 & \\
\hline \multirow[t]{2}{*}{ NRF-3 } & $6 / 17 / 91$ & $.080 \pm 0.479$ & $.453 \pm 0.501$ & 1.08 & \\
\hline & $12 / 03 / 92$ & $.209 \pm 0.539$ & $.483 \pm 0.587$ & .69 & \\
\hline \multirow[t]{2}{*}{ NRF-4 } & $2 / 07 / 91$ & $.182 \pm 0.507$ & $.638 \pm 0.567$ & 1.20 & \\
\hline & $4 / 07 / 93$ & $.262 \pm 0.479$ & $.327 \pm 0.469$ & .19 & \\
\hline NRF-6 & $3 / 10 / 92$ & $.537 \pm 0.491$ & $.421 \pm 0.531$ & .32 & \\
\hline NRF-7 & $1 / 08 / 92$ & $.696 \pm 0.538$ & $.608 \pm 0.525$ & .23 & \\
\hline \multirow[t]{2}{*}{ WSINEL1 } & $12 / 07 / 90$ & $.043 \pm 0.455$ & $.378 \pm 0.521$ & .97 & \\
\hline & $12 / 03 / 91$ & $.055 \pm 0.494$ & $.384 \pm 0.542$ & .90 & \\
\hline \multirow[t]{2}{*}{ USGS 12} & $6 / 15 / 90$ & $.318 \pm 0.575$ & $-.079 \pm 0.609$ & .95 & \\
\hline & 9/06/91 & $.693 \pm 0.542$ & $.430 \pm 0.504$ & .71 & \\
\hline \multirow[t]{2}{*}{ USGS 15} & $8 / 06 / 90$ & $2.12 \pm 0.829$ & $7.40 \pm 2.05$ & 4.78 & $\mathbf{N}$ \\
\hline & $3 / 12 / 92$ & $.266 \pm 0.496$ & $.313 \pm 0.489$ & .13 & \\
\hline USGS 17 & $3 / 13 / 91$ & $.646 \pm 0.601$ & $.672 \pm 0.633$ & .06 & \\
\hline \multirow[t]{3}{*}{ USGS 97} & $6 / 07 / 90$ & $.114 \pm 0.596$ & $.314 \pm 0.541$ & .50 & \\
\hline & $12 / 07 / 90$ & $.119 \pm 0.425$ & $.191 \pm 0.495$ & .22 & \\
\hline & $6 / 07 / 91$ & $.381 \pm 0.472$ & $.427 \pm 0.503$ & .13 & \\
\hline \multirow[t]{2}{*}{ USGS 98} & $7 / 30 / 90$ & $.464 \pm 0.512$ & $.093 \pm 0.459$ & 1.08 & \\
\hline & $9 / 21 / 92$ & $.490 \pm 0.524$ & $.635 \pm 0.475$ & .41 & \\
\hline \multirow[t]{2}{*}{ USGS 99} & $10 / 03 / 90$ & $-.169 \pm 0.521$ & $-.088 \pm 0.532$ & .22 & \\
\hline & $6 / 16 / 92$ & $.457 \pm 0.532$ & $.480 \pm 0.536$ & .06 & \\
\hline \multirow[t]{2}{*}{ USGS 102} & $12 / 10 / 90$ & $.123 \pm 0.485$ & $-.052 \pm 0.471$ & .52 & \\
\hline & $12 / 09 / 92$ & $.023 \pm 0.510$ & $.242 \pm 0.543$ & .59 & \\
\hline
\end{tabular}


Table 40. Comparison of the results and standard deviations of replicate pairs of samples from the Idaho National Engineering Laboratory analyzed for gross beta radioactivity, dissolved in water, as strontium-90/yttrium-90 by the National Water Quality Laboratory

[Site identifier: see figures 1-3 for location of sites. QA: quality-assurance replicate sample. Z-value: see section on Statistical Comparisons of Replicate Pairs of Samples for explanation. Abbreviations: Sr-90/Y-90, strontium-90/yttrium-90; $\mathrm{pCi} / \mathrm{L}$, picocurie per liter, $\mathrm{N}$, the analytical results are not in statistical agreement]

\begin{tabular}{|c|c|c|c|c|c|}
\hline Site identifier & $\begin{array}{c}\text { Date } \\
\text { sampled }\end{array}$ & $\begin{array}{l}\text { Gross beta, dissolved, } \\
\mathrm{Sr}-90 / \mathrm{Y}-90 \\
(\mathrm{pCi} / \mathrm{L})\end{array}$ & $\begin{array}{l}\text { Gross beta, dissolved, } \\
\text { Sr-90/Y-90 QA } \\
\text { (pCi/L) }\end{array}$ & Z-value & Remark \\
\hline NRF-1 & $9 / 09 / 91$ & $2.45 \pm 1.18$ & $2.76 \pm 1.04$ & 0.39 & \\
\hline \multirow[t]{3}{*}{ NRF-2 } & $3 / 21 / 90$ & $3.48 \pm 1.02$ & $2.85 \pm 0.979$ & .89 & \\
\hline & $3 / 05 / 91$ & $2.92 \pm 0.975$ & $2.88 \pm 0.962$ & .06 & \\
\hline & 9/15/93 & $3.64 \pm 0.977$ & $3.61 \pm 1.00$ & .04 & \\
\hline \multirow[t]{2}{*}{ NRF-3 } & $6 / 17 / 91$ & $2.02 \pm 0.757$ & $2.20 \pm 0.805$ & .33 & \\
\hline & $12 / 03 / 92$ & $2.38 \pm 0.774$ & $2.03 \pm 0.739$ & .65 & \\
\hline \multirow[t]{2}{*}{ NRF-4 } & $2 / 07 / 91$ & $2.55 \pm 0.871$ & $3.43 \pm 1.03$ & 1.30 & \\
\hline & $4 / 07 / 93$ & $2.70 \pm 0.850$ & $3.76 \pm 1.02$ & 1.60 & \\
\hline NRF-6 & $3 / 10 / 92$ & $5.53 \pm 1.57$ & $4.78 \pm 1.52$ & .69 & \\
\hline NRF-7 & $1 / 08 / 92$ & $2.55 \pm 0.910$ & $2.61 \pm 0.706$ & .10 & \\
\hline \multirow[t]{2}{*}{ WSINEL1 } & $12 / 07 / 90$ & $4.27 \pm 1.20$ & $3.91 \pm 1.14$ & .43 & \\
\hline & $12 / 03 / 91$ & $3.78 \pm 1.26$ & $4.04 \pm 1.28$ & .29 & \\
\hline \multirow[t]{3}{*}{ USGS 12} & $6 / 15 / 90$ & $3.61 \pm 1.10$ & $2.62 \pm 0.809$ & 1.45 & \\
\hline & $9 / 06 / 91$ & $2.31 \pm 0.921$ & $1.67 \pm 0.799$ & 1.05 & \\
\hline & $11 / 05 / 93$ & $3.05 \pm 1.59$ & $2.98 \pm 0.862$ & .08 & \\
\hline \multirow[t]{2}{*}{ USGS 15} & $8 / 06 / 90$ & $2.95 \pm 0.996$ & $3.20 \pm 1.20$ & .32 & \\
\hline & $3 / 12 / 92$ & $1.48 \pm 0.591$ & $1.40 \pm 0.572$ & .19 & \\
\hline \multirow[t]{2}{*}{ USGS 17} & $3 / 13 / 91$ & $2.12+0.673$ & $2.26 \pm 0.674$ & .29 & \\
\hline & $6 / 11 / 93$ & $2.02 \pm 0.672$ & $2.32 \pm 0.889$ & .54 & \\
\hline \multirow[t]{4}{*}{ USGS 97} & $6 / 07 / 90$ & $2.68 \pm 0.983$ & $2.52 \pm 0.965$ & .23 & \\
\hline & $12 / 07 / 90$ & $3.49 \pm 0.965$ & $2.58 \pm 0.835$ & 1.43 & \\
\hline & $6 / 07 / 91$ & $3.20 \pm 0.977$ & $2.36 \pm 0.931$ & 1.24 & \\
\hline & $11 / 04 / 93$ & $3.14 \pm 0.874$ & $2.66 \pm 0.880$ & .77 & \\
\hline \multirow[t]{2}{*}{ USGS 98} & $7 / 30 / 90$ & $2.13 \pm 0.689$ & $2.75 \pm 0.786$ & 1.19 & \\
\hline & $9 / 21 / 92$ & $2.74 \pm 1.13$ & $2.72 \pm 0.794$ & .03 & \\
\hline \multirow[t]{2}{*}{ USGS 99} & $10 / 03 / 90$ & $1.75 \pm 0.720$ & $3.28 \pm 0.939$ & 2.59 & $\mathrm{~N}$ \\
\hline & $6 / 16 / 92$ & $1.70 \pm 0.678$ & $1.82 \pm 0.678$ & .25 & \\
\hline \multirow[t]{2}{*}{ USGS 102} & $12 / 10 / 90$ & $2.66 \pm 0.860$ & $3.14 \pm 0.931$ & .76 & \\
\hline & $12 / 09 / 92$ & $2.18 \pm 0.743$ & $2.44 \pm 0.768$ & .49 & \\
\hline
\end{tabular}


Table 41. Comparison of the results and standard deviations of replicate pairs of samples from the Idaho National Engineering Laboratory analyzed for gross beta radioactivity, suspended in water, as strontium-90/yttrium-90 by the National Water Quality Laboratory

[Site identifier: see figures 1-3 for location of sites. QA: quality-assurance replicate sample. Z-value: see section on Statistical Comparisons of Replicate Pairs of Samples for explanation. Abbreviations: Sr-90/Y-90, strontium-90/yttrium-90; pCi/L, picocurie per liter; $\mathrm{N}$, the analytical results are not in statistical agreement]

\begin{tabular}{|c|c|c|c|c|c|}
\hline Site identifier & Date sampled & $\begin{array}{l}\text { Gross beta, } \\
\text { suspended, } \\
\text { Sr-90/Y-90 } \\
\text { (pCi/L) }\end{array}$ & $\begin{array}{c}\text { Gross beta, } \\
\text { suspended, } \\
\text { Sr-90/Y-90 QA } \\
\text { (pCi/L) }\end{array}$ & $\mathrm{Z}$-value & Remark \\
\hline NRF-1 & $9 / 09 / 91$ & $0.415 \pm 0.545$ & $0.174 \pm 0.515$ & 0.64 & \\
\hline \multirow[t]{2}{*}{ NRF-2 } & $3 / 21 / 90$ & $.298 \pm 0.438$ & $-.114 \pm 0.436$ & 1.33 & \\
\hline & $3 / 05 / 91$ & $.582 \pm 0.473$ & $.447 \pm 0.498$ & .39 & \\
\hline \multirow[t]{2}{*}{ NRF-3 } & $6 / 17 / 91$ & $.078 \pm 0.464$ & $.427 \pm 0.473$ & 1.05 & \\
\hline & $12 / 03 / 92$ & $.200 \pm 0.515$ & $.468 \pm 0.569$ & .70 & \\
\hline \multirow[t]{2}{*}{ NRF-4 } & $2 / 07 / 91$ & $.174 \pm 0.485$ & $.617 \pm 0.480$ & 1.30 & \\
\hline & $4 / 07 / 93$ & $.250 \pm 0.459$ & $.308 \pm 0.443$ & .18 & \\
\hline NRF-6 & $3 / 10 / 92$ & $.520 \pm 0.476$ & $.403 \pm 0.508$ & .34 & \\
\hline NRF-7 & $1 / 08 / 92$ & $.676 \pm 0.522$ & $.573 \pm 0.495$ & .29 & \\
\hline \multirow[t]{2}{*}{ WSINEL1 } & $12 / 07 / 90$ & $.042 \pm 0.440$ & $.357 \pm 0.491$ & .96 & \\
\hline & $12 / 03 / 91$ & $.054 \pm 0.480$ & $.371 \pm 0.520$ & .90 & \\
\hline \multirow[t]{2}{*}{ USGS 12} & $6 / 15 / 90$ & $.256 \pm 0.463$ & $-.062 \pm 0.481$ & .95 & \\
\hline & $9 / 06 / 91$ & $.672 \pm 0.526$ & $.418 \pm 0.490$ & .71 & \\
\hline \multirow[t]{2}{*}{ USGS 15} & $8 / 06 / 90$ & $1.68 \pm 0.659$ & $5.74 \pm 1.60$ & 4.69 & $\mathbf{N}$ \\
\hline & $3 / 12 / 92$ & $.251 \pm 0.469$ & $.303 \pm 0.474$ & .16 & \\
\hline USGS 17 & $3 / 13 / 91$ & $.520 \pm 0.484$ & $.531 \pm 0.501$ & .03 & \\
\hline \multirow[t]{3}{*}{ USGS 97} & $6 / 07 / 90$ & $.090 \pm 0.468$ & $.252 \pm 0.435$ & .51 & \\
\hline & $12 / 07 / 90$ & $.114 \pm 0.406$ & $.180 \pm 0.467$ & .21 & \\
\hline & $6 / 07 / 91$ & $.360 \pm 0.446$ & $.409 \pm 0.481$ & .15 & \\
\hline \multirow[t]{2}{*}{ USGS 98} & $7 / 30 / 90$ & $.425 \pm 0.498$ & $.089 \pm 0.439$ & 1.01 & \\
\hline & $9 / 21 / 92$ & $.463 \pm .0 .494$ & $.607 \pm 0.454$ & .43 & \\
\hline \multirow[t]{2}{*}{ USGS 99} & $10 / 03 / 90$ & $-.165 \pm 0.507$ & $-.086 \pm 0.517$ & .22 & \\
\hline & $6 / 16 / 92$ & $.438 \pm 0.509$ & $.453 \pm 0.505$ & .04 & \\
\hline \multirow[t]{2}{*}{ USGS 102} & $12 / 10 / 90$ & $.116 \pm 0.458$ & $-.051 \pm 0.458$ & .52 & \\
\hline & $12 / 09 / 92$ & $.022 \pm 0.496$ & $.231 \pm 0.519$ & .58 & \\
\hline
\end{tabular}


Table 42. Comparison of the results and standard deviations of replicate pairs of samples from the Idaho National Engineering Laboratory analyzed for gross beta radioactivity by the Radiological and Environmental Sciences Laboratory

[Site identifier: see figures 1-3 for location of sites. QA: quality-assurance replicate sample. Z-value: see section on Statistical Comparisons of Replicate Pairs of Samples for explanation. Remark: the results of replicate pairs are statistically equivalent. Abbreviations: $\mathrm{pCi} / \mathrm{L}$, picocurie per liter]

\begin{tabular}{lccccc}
\hline Site identifier & Date sampled & $\begin{array}{c}\text { Gross beta } \\
(\mathrm{pCi} / \mathrm{L})\end{array}$ & $\begin{array}{c}\text { Gross beta QA } \\
(\mathrm{pCi} / \mathrm{L})\end{array}$ & Z-value & Remark \\
\hline Big Lost River & $10 / 09 / 91$ & $2 \pm 2$ & $1 \pm 2$ & 0.35 \\
Cerro Grande & $10 / 18 / 90$ & $5 \pm 2$ & $5 \pm 2$ & .00 & \\
USGS 8 & $4 / 03 / 91$ & $0 \pm 2$ & $3 \pm 2$ & 1.06 \\
USGS 11 & $10 / 08 / 91$ & $1.3 \pm 1.9$ & $2 \pm 2$ & .25 \\
USGS 14 & $10 / 01 / 92$ & $4 \pm 2$ & $4 \pm 2$ & .00 \\
& $4 / 16 / 93$ & $4 \pm 2$ & $4 \pm 2$ & .00 \\
\hline
\end{tabular}


Table 43. Comparison of the results and standard deviations of replicate pairs of samples from the Idaho National Engineering Laboratory analyzed for gamma radiation by the Radiological and Environmental Sciences Laboratory

[Site identifier: see figures 1-3 for location of sites. QA: quality-assurance replicate sample. Z-value: see section on Statistical Comparisons of Replicate Pairs of Samples for explanation. Abbreviations: $p C i / L$, picocurie per liter; N, the analytical results are not in statistical agreement]

\begin{tabular}{|c|c|c|c|c|c|}
\hline Site identifier & Date sampled & $\begin{array}{c}\text { Gamma radiation } \\
(\mathrm{pCi} / \mathrm{L})\end{array}$ & $\begin{array}{c}\text { Gamma radiation, } \\
\text { QA (pCi/L) }\end{array}$ & Z-value & Remark \\
\hline Big Lost River & $10 / 09 / 91$ & $20 \pm 20$ & $-10 \pm 30$ & 0.83 & \\
\hline Cerro Grande & $10 / 18 / 90$ & $.70 \pm 30$ & $11 \pm 29$ & 1.94 & \\
\hline PW-1 & $4 / 24 / 89$ & $-40 \pm 30$ & $0 \pm 30$ & .94 & \\
\hline PW-3 & $3 / 30 / 90$ & $10 \pm 30$ & $20 \pm 30$ & .24 & \\
\hline PW-4 & $4 / 29 / 91$ & $11 \pm 26$ & $-20 \pm 20$ & .95 & \\
\hline PW-8 & $4 / 05 / 91$ & $20 \pm 40$ & $-25 \pm 15$ & 1.05 & \\
\hline PW-9 & 4/06/93 & $0 \pm 30$ & $-41 \pm 15$ & 1.22 & \\
\hline RWMC Prod. & $10 / 30 / 90$ & $0 \pm 30$ & $-10 \pm 30$ & .24 & \\
\hline \multirow[t]{2}{*}{ TRA Disp. } & $1 / 18 / 90$ & $13 \pm 25$ & $10 \pm 30$ & .08 & \\
\hline & $10 / 11 / 90$ & $70 \pm 30$ & $0 \pm 30$ & 1.65 & \\
\hline USGS 8 & $4 / 03 / 91$ & $10 \pm 20$ & $-20 \pm 30$ & .83 & \\
\hline USGS 11 & $10 / 08 / 91$ & $20 \pm 30$ & $60 \pm 30$ & .94 & \\
\hline \multirow[t]{2}{*}{ USGS 14} & $10 / 01 / 92$ & $10 \pm 30$ & $-30 \pm 20$ & 1.11 & \\
\hline & $4 / 16 / 93$ & $0 \pm 30$ & $50 \pm 30$ & 1.18 & \\
\hline USGS 37 & $10 / 21 / 93$ & $30 \pm 20$ & $50 \pm 30$ & .55 & \\
\hline \multirow[t]{2}{*}{ USGS 40} & $10 / 18 / 89$ & $-20 \pm 40$ & $-20 \pm 40$ & .00 & \\
\hline & $4 / 25 / 91$ & $60 \pm 30$ & $-40 \pm 30$ & 2.36 & $\mathbf{N}$ \\
\hline USGS 43 & $4 / 13 / 90$ & $-40 \pm 40$ & $40 \pm 30$ & 1.60 & \\
\hline \multirow[t]{2}{*}{ USGS 44} & $10 / 26 / 90$ & $40 \pm 40$ & $-10 \pm 20$ & 1.12 & \\
\hline & $11 / 01 / 93$ & $-20 \pm 20$ & $0 \pm 20$ & .71 & \\
\hline USGS 46 & $10 / 09 / 91$ & $0 \pm 30$ & $0 \pm 20$ & .00 & \\
\hline USGS 47 & $4 / 10 / 91$ & $14 \pm 19$ & $-40 \pm 40$ & 1.22 & \\
\hline USGS 54 & $4 / 19 / 93$ & $-30 \pm 20$ & $0 \pm 30$ & .83 & \\
\hline USGS 58 & $4 / 03 / 91$ & $-10 \pm 20$ & $0 \pm 20$ & .35 & \\
\hline USGS 62 & $4 / 09 / 92$ & $16 \pm 22$ & $10 \pm 20$ & .20 & \\
\hline USGS 63 & $4 / 10 / 90$ & $13 \pm 36$ & $16 \pm 28$ & .07 & \\
\hline USGS 65 & $10 / 15 / 91$ & $-12 \pm 27$ & $20 \pm 30$ & .79 & \\
\hline USGS 66 & $4 / 29 / 92$ & $-20 \pm 30$ & $0 \pm 20$ & .55 & \\
\hline USGS 68 & $7 / 02 / 91$ & $20 \pm 30$ & $30 \pm 30$ & .24 & \\
\hline USGS 71 & $4 / 22 / 91$ & $10 \pm 40$ & $12 \pm 26$ & .04 & \\
\hline \multirow[t]{3}{*}{ USGS 76} & $1 / 05 / 90$ & $0 \pm 30$ & $60 \pm 50$ & 1.03 & \\
\hline & $10 / 17 / 90$ & $-20 \pm 40$ & $-30 \pm 20$ & .22 & \\
\hline & $4 / 26 / 93$ & $-20 \pm 30$ & $20 \pm 30$ & .94 & \\
\hline USGS 87 & $4 / 21 / 92$ & $0 \pm 20$ & $40 \pm 30$ & 1.11 & \\
\hline USGS 88 & $7 / 12 / 89$ & $20 \pm 30$ & $-20 \pm 30$ & .94 & \\
\hline
\end{tabular}


Table 43. Comparison of the results and standard deviations of replicate pairs of samples from the Idaho National Engineering Laboratory analyzed for gamma radiation by the Radiological and Environmental Sciences Laboratory-continued

\begin{tabular}{lccccc}
\hline Site identifier & Date sampled & $\begin{array}{c}\text { Gamma radiation } \\
(\mathrm{pCi} / \mathrm{L})\end{array}$ & $\begin{array}{c}\text { Gamma radiation, } \\
\mathrm{QA}(\mathrm{pCi} / \mathrm{L})\end{array}$ & Z-value & Remark \\
\hline USGS 88 - cont. & $7 / 16 / 91$ & $70 \pm 30$ & $70 \pm 40$ & 0.00 & \\
& $1 / 20 / 93$ & $16 \pm 29$ & $20 \pm 30$ & .10 & \\
USGS 89 & $1 / 04 / 89$ & $0 \pm 30$ & $0 \pm 20$ & .00 & \\
& $10 / 16 / 91$ & $-2 \pm 15$ & $10 \pm 20$ & .48 & \\
USGS 90 & $1 / 18 / 89$ & $90 \pm 30$ & $-70 \pm 30$ & 3.77 & $\mathrm{~N}$ \\
& $1 / 23 / 90$ & $50 \pm 40$ & $-30 \pm 30$ & 1.60 & \\
& $1 / 16 / 92$ & $-10 \pm 20$ & $17 \pm 27$ & .80 & \\
& $4 / 20 / 92$ & $0 \pm 20$ & $20 \pm 20$ & .71 & \\
& $10 / 04 / 93$ & $-40 \pm 30$ & $-20 \pm 20$ & .55 & \\
USGS 117 & $4 / 18 / 91$ & $-30 \pm 20$ & $0 \pm 40$ & .67 & \\
USGS 119 & $4 / 03 / 89$ & $-14 \pm 39$ & $0 \pm 30$ & .28 & \\
& $4 / 09 / 90$ & $60 \pm 30$ & $0 \pm 30$ & 1.41 & \\
USGS 120 & $7 / 19 / 90$ & $-30 \pm 40$ & $10 \pm 30$ & .80 \\
\hline
\end{tabular}


Table 44. Comparison of the results and standard deviations of replicate pairs of samples from the Idaho National Engineering Laboratory analyzed for radium-226 and radium-228 by the National Water Quality Laboratory

[Site identifier: see figures 1-3 for location of sites. QA: quality-assurance replicate sample. Z-value: see section on Statistical Comparisons of Replicate Pairs of Samples for explanation. Abbreviations: pCi/L, picocurie per liter; N, the analytical results are not in statistical agreement]

\begin{tabular}{|c|c|c|c|c|c|}
\hline Site identifier & Date sampled & $\begin{array}{l}\text { Radium-226 } \\
\text { (pCi/L) }\end{array}$ & $\begin{array}{l}\text { Radium-226 QA } \\
\qquad(\mathrm{pCi} / \mathrm{L})\end{array}$ & Z-value & Remark \\
\hline NRF-4 & $2 / 07 / 91$ & $0.035 \pm 0.014$ & $0.023 \pm 0.008$ & 1.49 & \\
\hline NRF-6 & $3 / 10 / 92$ & $.017 \pm 0.013$ & $.029 \pm 0.009$ & 1.52 & \\
\hline NRF-7 & $1 / 08 / 92$ & $.047 \pm 0.011$ & $.042 \pm 0.014$ & .54 & \\
\hline WSINEL1 & $12 / 07 / 90$ & $.089 \pm 0.020$ & $.152 \pm 0.026$ & 3.84 & $\mathbf{N}$ \\
\hline USGS 12 & $6 / 15 / 90$ & $.064 \pm 0.014$ & $.050 \pm 0.012$ & 1.52 & \\
\hline USGS 15 & $8 / 06 / 90$ & $.102 \pm 0.018$ & $.048 \pm 0.014$ & 4.74 & $\mathrm{~N}$ \\
\hline \multirow[t]{2}{*}{ USGS 97} & $6 / 07 / 90$ & $.097 \pm 0.018$ & $.088 \pm 0.018$ & .71 & \\
\hline & $12 / 07 / 90$ & $.086 \pm 0.016$ & $.094 \pm 0.020$ & .62 & \\
\hline USGS 98 & $7 / 30 / 90$ & $.093 \pm 0.020$ & $.054 \pm 0.016$ & 3.05 & $\mathbf{N}$ \\
\hline USGS 99 & $10 / 03 / 90$ & $.011 \pm 0.016$ & $.109 \pm 0.020$ & 7.65 & $\mathbf{N}$ \\
\hline USGS 102 & $12 / 10 / 90$ & $.087 \pm 0.018$ & $.116 \pm 0.022$ & 2.04 & $\mathbf{N}$ \\
\hline Site identifier & Date sampled & $\begin{array}{l}\text { Radium-228 } \\
\text { (pCi/L) }\end{array}$ & $\begin{array}{l}\text { Radium-228 QA } \\
(\mathrm{pCi} / \mathrm{L})\end{array}$ & Z-value & Remark \\
\hline NRF-2 & $3 / 21 / 90$ & $0.085 \pm 0.252$ & $0.144 \pm 0.327$ & 0.29 & \\
\hline NRF-4 & 2/07/91 & $.370 \pm 0.319$ & $.215 \pm 0.279$ & .73 & \\
\hline NRF-6 & $3 / 10 / 92$ & $.232 \pm 0.279$ & $.233 \pm 0.303$ & .00 & \\
\hline NRF-7 & $1 / 08 / 92$ & $.175 \pm 0.257$ & $.126 \pm 0.268$ & .26 & \\
\hline WSINEL1 & $12 / 07 / 90$ & $.256 \pm 0.263$ & $.437 \pm 0.280$ & .94 & \\
\hline USGS 12 & $6 / 15 / 90$ & $.409 \pm 0.684$ & $.153 \pm 0.602$ & .56 & \\
\hline USGS 15 & $8 / 06 / 90$ & $.058 \pm 0.756$ & $.539 \pm 0.896$ & .82 & \\
\hline \multirow[t]{2}{*}{ USGS 97} & $6 / 07 / 90$ & $.111 \pm 0.366$ & $.393 \pm 0.448$ & .97 & \\
\hline & $12 / 07 / 90$ & $.224 \pm 0.261$ & $.086 \pm 0.237$ & .78 & \\
\hline USGS 98 & $7 / 30 / 90$ & $-.070 \pm 0.474$ & $.260 \pm 0.422$ & 1.04 & \\
\hline USGS 99 & $10 / 03 / 90$ & $.442 \pm 0.247$ & $.449 \pm 0.282$ & .04 & \\
\hline USGS 102 & $12 / 10 / 90$ & $.222 \pm 0.252$ & $.256 \pm 0.245$ & .19 & \\
\hline
\end{tabular}


Table 45. Comparison of the results and standard deviations of replicate pairs of samples from the Idaho National Engineering Laboratory analyzed for strontium-90 by the Radiological and Environmental Sciences Laboratory

[Site identifier: see figures 1-3 for location of sites. QA: quality-assurance replicate sample. Z-value: see section on Statistical Comparisons of Replicate Pairs of Samples for explanation. Abbreviations: pCi/L, picocurie per liter; N, the analytical results are not in statistical agreement. Symbols: ${ }^{\otimes}$, the QA sample was collected within 24 hours]

\begin{tabular}{|c|c|c|c|c|c|}
\hline Site identifier & Date sampled & $\begin{array}{l}\text { Strontium-90 } \\
(\mathrm{pCi} / \mathrm{L})\end{array}$ & $\begin{array}{c}\text { Strontium-90 QA } \\
(\mathrm{pCi} / \mathrm{L})\end{array}$ & $\mathrm{Z}$-value & Remark \\
\hline Area II & $7 / 14 / 93$ & $-2 \pm 2$ & $1 \pm 2$ & 1.06 & \\
\hline \multirow[t]{2}{*}{ CPP 1} & $11 / 06 / 89$ & $2.1 \pm 1.3$ & $2.3 \pm 1.3$ & .11 & \\
\hline & $10 / 31 / 90$ & $-1.4 \pm 2.1$ & $-1.3 \pm 2.0$ & .03 & \\
\hline \multirow[t]{3}{*}{ CPP 2} & $1 / 31 / 89$ & $-.9 \pm 1.5$ & $-2.1 \pm 1.4$ & .58 & \\
\hline & $7 / 26 / 89$ & $-5 \pm 2$ & $-7 \pm 2$ & .71 & \\
\hline & $4 / 29 / 92$ & $-.3 \pm 1.4$ & $.5 \pm 1.6$ & .38 & \\
\hline CPP 4 & $7 / 23 / 90$ & $0 \pm 2$ & $.9 \pm 1.6$ & .35 & \\
\hline \multirow[t]{2}{*}{ CWP-4 } & $4 / 25 / 89$ & $2 \pm 1.4$ & $.4 \pm 1.5$ & .78 & \\
\hline & $4 / 17 / 91$ & $-4.9 \pm 1.5$ & $-4 \pm 2$ & .36 & \\
\hline CWP-5 & $10 / 14 / 93$ & $.8 \pm 1.5$ & $3 \pm 2$ & .88 & \\
\hline \multirow[t]{3}{*}{ PW-1 } & $4 / 24 / 89$ & $20 \pm 2$ & $22 \pm 2$ & .71 & \\
\hline & $10 / 27 / 89$ & $18 \pm 2$ & $21 \pm 2$ & 1.06 & \\
\hline & $7 / 03 / 90$ & $19 \pm 2$ & $20 \pm 2$ & .35 & \\
\hline \multirow[t]{2}{*}{ PW-2 } & $1 / 08 / 91$ & $6 \pm 2$ & $3 \pm 2$ & 1.06 & \\
\hline & $10 / 25 / 93$ & $0 \pm 2$ & $9 \pm 2$ & 3.18 & $\mathbf{N}$ \\
\hline PW-3 & $3 / 30 / 90$ & $12 \pm 2$ & $10 \pm 2$ & .71 & \\
\hline \multirow[t]{4}{*}{ PW-4 } & $2 / 02 / 90$ & $3.8 \pm 1.7$ & $6 \pm 2$ & .84 & \\
\hline & $10 / 17 / 90$ & $8 \pm 2$ & $10 \pm 3$ & .55 & \\
\hline & $4 / 29 / 91$ & $8 \pm 2$ & $7 \pm 2$ & .35 & \\
\hline & $10 / 22 / 92$ & $8 \pm 2$ & $8 \pm 2$ & .00 & \\
\hline PW-5 & $10 / 17 / 91$ & $11 \pm 2$ & $12 \pm 3$ & .28 & \\
\hline \multirow[t]{2}{*}{ PW-8 } & $4 / 05 / 91$ & $18 \pm 2$ & $18 \pm 2$ & .00 & \\
\hline & $7 / 17 / 93$ & $16 \pm 2$ & $12 \pm 2$ & 1.41 & \\
\hline \multirow[t]{2}{*}{ PW-9 } & $2 / 04 / 93$ & $-2 \pm 2$ & $4 \pm 2$ & 2.12 & $\mathbf{N}$ \\
\hline & $4 / 06 / 93$ & $-.7 \pm 1.6$ & $3 \pm 2$ & 1.44 & \\
\hline RWMC Prod. & $10 / 30 / 90$ & $1 \pm 2$ & $-1 \pm 2$ & .71 & \\
\hline Site 14 & $10 / 18 / 91$ & $1.3 \pm 2.4$ & $-3 \pm 2$ & 1.38 & \\
\hline USGS 1 & $7 / 20 / 92$ & $1.1 \pm 1.5$ & $1.7 \pm 1.5$ & .28 & \\
\hline USGS 20 & $4 / 08 / 91$ & $.8 \pm 1.6$ & $-1.9 \pm 1.5$ & 1.23 & \\
\hline USGS 23 & $7 / 09 / 93$ & $1.4 \pm 1.7$ & $-1 \pm 2$ & .91 & \\
\hline USGS 32 & $7 / 06 / 92$ & $-.4 \pm 1.3$ & $-2.5 \pm 1.5$ & 1.06 & \\
\hline USGS 34 & $4 / 01 / 91$ & $3 \pm 2$ & $4 \pm 2$ & .35 & \\
\hline \multirow[t]{3}{*}{ USGS 35} & $10 / 07 / 91$ & $-7 \pm 2$ & $4 \pm 2$ & 3.89 & $\mathbf{N}$ \\
\hline & $4 / 14 / 93$ & $2 \pm 2$ & $5 \pm 2$ & 1.06 & \\
\hline & $10 / 21 / 93$ & $7 \pm 3$ & ${ }^{\otimes} 6 \pm 2$ & .28 & \\
\hline
\end{tabular}


Table 45. Comparison of the results and standard deviations of replicate pairs of samples from the Idaho National Engineering Laboratory analyzed for strontium-90 by the Radiological and Environmental Sciences Laboratory-continued

\begin{tabular}{|c|c|c|c|c|c|}
\hline Site identifier & Date sampled & $\begin{array}{l}\text { Strontium-90 } \\
(\mathrm{pCi} / \mathrm{L})\end{array}$ & $\begin{array}{l}\text { Strontium-90 QA } \\
(\mathrm{pCi} / \mathrm{L})\end{array}$ & Z-value & Remark \\
\hline \multirow[t]{3}{*}{ USGS 37} & $1 / 02 / 90$ & $16 \pm 2$ & $14 \pm 2$ & 0.71 & \\
\hline & $4 / 18 / 90$ & $13 \pm 2$ & $9 \pm 2$ & 1.41 & \\
\hline & $10 / 21 / 93$ & $20 \pm 3$ & $14 \pm 2$ & 1.66 & \\
\hline \multirow[t]{2}{*}{ USGS 38} & $4 / 23 / 92$ & $27 \pm 2$ & $27 \pm 3$ & .00 & \\
\hline & $10 / 14 / 92$ & $27 \pm 3$ & $22 \pm 3$ & 1.18 & \\
\hline \multirow[t]{2}{*}{ USGS 40} & $10 / 18 / 89$ & $31 \pm 3$ & $24 \pm 3$ & 1.65 & \\
\hline & $4 / 25 / 91$ & $22 \pm 3$ & $22 \pm 3$ & .00 & \\
\hline USGS 43 & $4 / 13 / 90$ & $-.5 \pm 1.6$ & $1.2 \pm 1.5$ & .78 & - \\
\hline \multirow[t]{2}{*}{ USGS 44} & $10 / 26 / 90$ & $6 \pm 2$ & $6 \pm 2$ & .00 & \\
\hline & $11 / 01 / 93$ & $5 \pm 2$ & $7 \pm 2$ & .82 & \\
\hline USGS 45 & $4 / 20 / 92$ & $1.2 \pm 1.5$ & $.7 \pm 1.6$ & .23 & \\
\hline USGS 46 & $10 / 09 / 91$ & $10 \pm 3$ & $10 \pm 3$ & .00 & \\
\hline USGS 47 & $4 / 10 / 91$ & $50 \pm 4$ & $48 \pm 4$ & .35 & \\
\hline USGS 52 & $4 / 03 / 90$ & $14 \pm 2$ & $9 \pm 2$ & 1.77 & \\
\hline \multirow[t]{4}{*}{ USGS 54} & $10 / 16 / 92$ & $95 \pm 5$ & $98 \pm 5$ & .42 & \\
\hline & $4 / 19 / 93$ & $86 \pm 5$ & $90 \pm 5$ & .57 & \\
\hline & $7 / 22 / 93$ & $101 \pm 5$ & $\otimes_{105 \pm 5}$ & .57 & \\
\hline & $10 / 13 / 93$ & $94 \pm 5$ & $99 \pm 5$ & .71 & \\
\hline \multirow[t]{4}{*}{ USGS 57} & $12 / 22 / 89$ & $45 \pm 4$ & $43 \pm 3$ & .40 & \\
\hline & $6 / 28 / 90$ & $46 \pm 4$ & $43 \pm 3$ & .60 & \\
\hline & $10 / 29 / 90$ & $41 \pm 4$ & $34 \pm 3$ & 1.40 & \\
\hline & $7 / 21 / 93$ & $36 \pm 3$ & $\otimes_{33+3}$ & .71 & \\
\hline \multirow[t]{4}{*}{ USGS 59} & $4 / 17 / 89$ & $15 \pm 2$ & $14 \pm 2$ & .35 & \\
\hline & $4 / 28 / 92$ & $11 \pm 2$ & $14 \pm 2$ & 1.06 & \\
\hline & $4 / 22 / 93$ & $14 \pm 2$ & $13 \pm 2$ & .35 & \\
\hline & $10 / 25 / 93$ & $9 \pm 2$ & $14 \pm 2$ & 1.77 & \\
\hline USGS 60 & $1 / 10 / 92$ & $2 \pm 2$ & $1.9 \pm 1.6$ & .04 & \\
\hline USGS 61 & $9 / 27 / 90$ & $0 \pm 2$ & $-2 \pm 2$ & .71 & \\
\hline \multirow[t]{2}{*}{ USGS 62} & $4 / 09 / 92$ & $1.2 \pm 1.3$ & $-.4 \pm 1.4$ & .84 & \\
\hline & $10 / 13 / 92$ & $0 \pm 2$ & $-2 \pm 2$ & .71 & \\
\hline USGS 65 & $10 / 15 / 91$ & $0 \pm 2$ & $0 \pm 2$ & .00 & \\
\hline USGS 66 & $4 / 29 / 92$ & $2.4 \pm 1.5$ & $-1.9 \pm 1.6$ & 1.96 & $\mathrm{~N}$ \\
\hline \multirow[t]{3}{*}{ USGS 68} & $4 / 27 / 89$ & $-3 \pm 2$ & $51 \pm 4$ & 12.07 & $\mathrm{~N}$ \\
\hline & $7 / 02 / 91$ & $6 \pm 2$ & $0 \pm 2$ & 2.12 & $\mathbf{N}$ \\
\hline & $1 / 17 / 92$ & $-.3 \pm 1.4$ & $.7 \pm 1.6$ & .47 & \\
\hline USGS 69 & $10 / 24 / 91$ & $-3 \pm 2$ & $0 \pm 2$ & 1.06 & \\
\hline \multirow[t]{2}{*}{ USGS 71} & $4 / 22 / 91$ & $3 \pm 2$ & $.5 \pm 1.5$ & 1.00 & \\
\hline & $10 / 12 / 93$ & $-3 \pm 2$ & $2 \pm 1.7$ & 1.90 & \\
\hline
\end{tabular}


Table 45. Comparison of the results and standard deviations of replicate pairs of samples from the Idaho National Engineering Laboratory analyzed for strontium-90 by the Radiological and Environmental Sciences Laboratory-continued

\begin{tabular}{|c|c|c|c|c|c|}
\hline Site identifier & Date sampled & $\begin{array}{l}\text { Strontium-90 } \\
(\mathrm{pCi} / \mathrm{L})\end{array}$ & $\begin{array}{c}\text { Strontium-90 QA } \\
(\mathrm{pCi} / \mathrm{L})\end{array}$ & $\mathrm{Z}$-value & Remark \\
\hline USGS 72 & $10 / 28 / 93$ & $-1 \pm 2$ & $1.1 \pm 1.6$ & 0.82 & \\
\hline \multirow[t]{4}{*}{ USGS 76} & $1 / 05 / 90$ & $-2.4 \pm 1.4$ & $-1.7 \pm 1.6$ & .33 & \\
\hline & $10 / 17 / 90$ & $3 \pm 2$ & $.9 \pm 1.6$ & .82 & \\
\hline & $4 / 26 / 93$ & $-1.1 \pm 1.8$ & $-1.4 \pm 1.5$ & .13 & \\
\hline & $10 / 22 / 93$ & $0 \pm 2$ & $\otimes-.7 \pm 1.5$ & .28 & \\
\hline USGS 77 & $10 / 09 / 92$ & $0 \pm 2$ & $-1.0 \pm 2$ & .35 & \\
\hline \multirow[t]{2}{*}{ USGS 82} & $4 / 15 / 92$ & $2.2 \pm 1.6$ & $-.4 \pm 1.6$ & 1.15 & \\
\hline & $7 / 07 / 93$ & $.8 \pm 1.7$ & $1.3 \pm 1.8$ & .20 & \\
\hline \multirow[t]{2}{*}{ USGS 85} & $4 / 26 / 90$ & $4 \pm 2$ & $2 \pm 2$ & .71 & \\
\hline & $4 / 19 / 93$ & $2 \pm 2$ & $2 \pm 2$ & .00 & \\
\hline USGS 87 & $4 / 21 / 92$ & $-1.1 \pm 2.1$ & $-1.0 \pm 2.0$ & .03 & \\
\hline \multirow[t]{3}{*}{ USGS 88} & $7 / 12 / 89$ & $-.6 \pm 1.5$ & $-1.7 \pm 1.5$ & .52 & \\
\hline & $7 / 16 / 91$ & $-1.6 \pm 2.4$ & $-3 \pm 2$ & .45 & \\
\hline & $1 / 20 / 93$ & $-1.6 \pm 1.9$ & $-1.6 \pm 1.9$ & .00 & \\
\hline \multirow[t]{3}{*}{ USGS 89} & $1 / 04 / 89$ & $0 \pm 1.3$ & $3.3 \pm 1.4$ & 1.73 & \\
\hline & $10 / 16 / 91$ & $-2 \pm 2$ & $-2 \pm 2$ & .00 & \\
\hline & $1 / 17 / 92$ & $-.6 \pm 1.4$ & $-.1 \pm 1.2$ & .27 & \\
\hline \multirow[t]{5}{*}{ USGS 90} & $1 / 18 / 89$ & $.4 \pm 1.3$ & $1.5 \pm 1.4$ & .58 & \\
\hline & $1 / 23 / 90$ & $-2.9 \pm 1.6$ & $-2.4 \pm 1.6$ & .22 & \\
\hline & $1 / 16 / 92$ & $.6 \pm 1.4$ & $1.0 \pm 1.5$ & .19 & \\
\hline & $4 / 20 / 92$ & $-2 \pm 2$ & $0 \pm 2$ & .71 & \\
\hline & $10 / 04 / 93$ & $-.8 \pm 1.4$ & $-1 \pm 2$ & .08 & \\
\hline USGS 111 & $3 / 20 / 90$ & $1 \pm 2$ & $-2 \pm 1.6$ & 1.17 & \\
\hline USGS 113 & $7 / 15 / 91$ & $19 \pm 3$ & $15 \pm 3$ & .94 & \\
\hline \multirow[t]{3}{*}{ USGS 114} & $10 / 05 / 89$ & $.9 \pm 1.5$ & $.6 \pm 1.4$ & .15 & \\
\hline & $9 / 24 / 90$ & $-2 \pm 2$ & $1 \pm 2$ & 1.06 & \\
\hline & $10 / 21 / 91$ & $3 \pm 2$ & $-4 \pm 2$ & 2.47 & $\mathbf{N}$ \\
\hline USGS 115 & $7 / 16 / 93$ & $-4 \pm 2$ & $1.3 \pm 1.7$ & 2.02 & $\mathrm{~N}$ \\
\hline \multirow[t]{2}{*}{ USGS 116} & $4 / 06 / 89$ & $-4.3 \pm 1.5$ & $-4 \pm 2$ & .12 & \\
\hline & $10 / 05 / 89$ & $1 \pm 1.5$ & $-1.3 \pm 1.3$ & 1.16 & \\
\hline USGS 117 & $4 / 18 / 91$ & $1 \pm 1.7$ & $-1 \pm 2$ & .76 & \\
\hline \multirow[t]{3}{*}{ USGS 119} & $4 / 03 / 89$ & $0 \pm 1.5$ & $.3 \pm 1.4$ & .15 & \\
\hline & $6 / 28 / 89$ & $-1.4 \pm 1.4$ & $-.7 \pm 1.4$ & .35 & \\
\hline & 4/09/90 & $1.8 \pm 1.6$ & $-.2 \pm 1.5$ & .91 & \\
\hline USGS 119 & $7 / 09 / 92$ & $-4 \pm 2$ & $-1.2 \pm 1.5$ & 1.12 & \\
\hline USGS 120 & $7 / 19 / 90$ & $3 \pm 2$ & $2 \pm 2$ & .35 & \\
\hline \multirow[t]{2}{*}{ USGS 122} & $10 / 15 / 91$ & $-1 \pm 2$ & $1.6 \pm 2.2$ & .87 & \\
\hline & $4 / 15 / 92$ & $0 \pm 2$ & $3 \pm 2$ & 1.06 & \\
\hline
\end{tabular}


Table 46. Comparison of the results and standard deviations of replicate pairs of samples from the Idaho National Engineering Laboratory analyzed for tritium by the National Water Quality Laboratory and the Radiological and Environmental Sciences Laboratory

[Site identifier: see figures 1-3 for location of sites. QA: quality-assurance replicate sample. Z-value: see section on Statistical Comparisons of Replicate Pairs of Samples for explanation. Abbreviations: pCi/L, picocurie per liter; N, the analytical results are not in statistical agreement. Symbols: " the analyses were performed by the National Water Quality Laboratory; ${ }^{\otimes}$, the QA sample was collected within 24 hours]

\begin{tabular}{|c|c|c|c|c|c|}
\hline Site identifier & Date sampled & $\begin{array}{l}\text { Tritium } \\
(\mathrm{pCi} / \mathrm{L})\end{array}$ & $\begin{array}{c}\text { Tritium QA } \\
(\mathrm{pC} / \mathrm{L})\end{array}$ & $Z$-value & Remark \\
\hline ARBOR Test & $10 / 01 / 91$ & $0 \pm 200$ & $-90 \pm 160$ & 0.35 & \\
\hline Area II & $7 / 14 / 93$ & $70 \pm 160$ & $90 \pm 160$ & .09 & \\
\hline Badging Facility & $4 / 19 / 90$ & $-100 \pm 200$ & $0 \pm 200$ & .35 & \\
\hline Big Lost River & $10 / 09 / 91$ & $140 \pm 170$ & $10 \pm 170$ & .54 & \\
\hline Birch Creek & $4 / 05 / 90$ & $-100 \pm 180$ & $-100 \pm 200$ & .00 & \\
\hline Cerro Grande & $10 / 18 / 90$ & $300 \pm 200$ & $300 \pm 200$ & .00 & \\
\hline CFA-2 & $7 / 25 / 91$ & $16,900 \pm 500$ & $16,500 \pm 500$ & .57 & \\
\hline \multirow[t]{2}{*}{ CPP 1} & $11 / 06 / 89$ & $120 \pm 160$ & $230 \pm 160$ & .49 & \\
\hline & $10 / 31 / 90$ & $400 \pm 200$ & $300 \pm 200$ & .35 & \\
\hline \multirow[t]{3}{*}{ CPP 2} & $1 / 31 / 89$ & $70 \pm 160$ & $40 \pm 160$ & .13 & \\
\hline & $7 / 26 / 89$ & $30 \pm 160$ & $20 \pm 160$ & .04 & \\
\hline & $4 / 29 / 92$ & $0 \pm 200$ & $0 \pm 200$ & .00 & \\
\hline CPP 4 & $7 / 23 / 90$ & $130 \pm 180$ & $0 \pm 200$ & .48 & \\
\hline \multirow[t]{2}{*}{ CWP-4 } & $4 / 25 / 89$ & $-10 \pm 150$ & $-30 \pm 150$ & .09 & \\
\hline & $4 / 17 / 91$ & $50 \pm 160$ & $50 \pm 160$ & .00 & \\
\hline CWP-5 & $10 / 14 / 93$ & $0 \pm 200$ & $-100 \pm 200$ & .35 & . \\
\hline \multirow[t]{3}{*}{ EBR I } & $4 / 28 / 89$ & $-60 \pm 150$ & $-60 \pm 150$ & .00 & \\
\hline & $4 / 19 / 90$ & $0 \pm 200$ & $-120 \pm 170$ & .46 & \\
\hline & $4 / 08 / 93$ & $-70 \pm 170$ & $-110 \pm 170$ & .17 & \\
\hline \multirow[t]{2}{*}{ Fire Station 2} & $4 / 18 / 91$ & $50 \pm 160$ & $110 \pm 160$ & .27 & \\
\hline & $10 / 08 / 92$ & $100 \pm 200$ & $0 \pm 200$ & .35 & \\
\hline MTR Test & $10 / 07 / 92$ & $2,900 \pm 300$ & $2,900 \pm 300$ & .00 & \\
\hline OMRE & $4 / 28 / 89$ & $2,700+200$ & $2,600 \pm 200$ & .35 & \\
\hline \multirow[t]{3}{*}{ PW-1 } & $4 / 24 / 89$ & $1,500 \pm 200$ & $1,600 \pm 200$ & .35 & \\
\hline & $10 / 27 / 89$ & $4,900 \pm 300$ & $4,900 \pm 300$ & .00 & \\
\hline & $7 / 03 / 90$ & $1,400 \pm 200$ & $1,400 \pm 200$ & .00 & \\
\hline \multirow[t]{2}{*}{ PW-2 } & $1 / 08 / 91$ & $25,700 \pm 700$ & $25,600 \pm 700$ & .10 & \\
\hline & $10 / 25 / 93$ & $700 \pm 200$ & $800 \pm 200$ & .35 & \\
\hline PW-3 & $3 / 30 / 90$ & $20,200 \pm 600$ & $19,500 \pm 600$ & .82 & \\
\hline PW-4 & $2 / 02 / 90$ & $2,300 \pm 200$ & $2,400 \pm 200$ & .35 & \\
\hline \multirow[t]{3}{*}{ PW-4 } & $10 / 17 / 90$ & $5,000 \pm 300$ & $5,100 \pm 300$ & .24 & \\
\hline & $4 / 29 / 91$ & $3,500 \pm 300$ & $3,200 \pm 300$ & .71 & \\
\hline & $10 / 22 / 92$ & $1,700 \pm 200$ & $1,500 \pm 200$ & .71 & \\
\hline PW-5 & $10 / 17 / 91$ & $900 \pm 200$ & $1,000 \pm 200$ & .35 & \\
\hline
\end{tabular}


Table 46. Comparison of the results and standard deviations of replicate pairs of samples from the Idaho National Engineering Laboratory analyzed for tritium by the National Water Quality Laboratory and the Radiological and Environmental Sciences Laboratory-continued

\begin{tabular}{|c|c|c|c|c|c|}
\hline Site identifier & Date sampled & $\begin{array}{l}\text { Tritium } \\
(\mathrm{pCi} / \mathrm{L})\end{array}$ & $\begin{array}{l}\text { Tritium QA } \\
(\mathrm{pCi} / \mathrm{L})\end{array}$ & $Z$-value & Remark \\
\hline \multirow[t]{2}{*}{ PW-8 } & $4 / 05 / 91$ & $3,600 \pm 300$ & $3,400 \pm 300$ & 0.47 & \\
\hline & $7 / 17 / 93$ & $14,600 \pm 500$ & $14,100 \pm 500$ & .71 & \\
\hline \multirow[t]{2}{*}{ PW-9 } & $2 / 04 / 93$ & $232,000 \pm 4,000$ & $229,000 \pm 4000$ & .53 & \\
\hline & $4 / 06 / 93$ & $237,000 \pm 4,000$ & $238,000 \pm 4,000$ & .18 & \\
\hline \multirow[t]{2}{*}{ P\&W2 } & $4 / 18 / 89$ & $-10 \pm 150$ & $-30 \pm 150$ & .09 & \\
\hline & $3 / 14 / 90$ & $0 \pm 200$ & $0 \pm 200$ & .00 & \\
\hline RWMC Prod. & $10 / 30 / 90$ & $1,700 \pm 200$ & $1,700 \pm 200$ & .00 & \\
\hline Site 9 & $9 / 27 / 91$ & $-50 \pm 170$ & $100 \pm 200$ & .57 & \\
\hline \multirow[t]{2}{*}{ Site 14} & $10 / 18 / 91$ & $-30 \pm 170$ & $-50 \pm 170$ & .08 & \\
\hline & $11 / 04 / 93$ & $100 \pm 200$ & $100 \pm 200$ & .00 & \\
\hline \multirow[t]{2}{*}{ Site 19} & $10 / 01 / 90$ & $100 \pm 200$ & $-140 \pm 170$ & .91 & \\
\hline & $4 / 07 / 92$ & $-200 \pm 200$ & $-200 \pm 200$ & .00 & \\
\hline SPERT-1 & $4 / 28 / 89$ & $140 \pm 160$ & $-90 \pm 150$ & 1.05 & \\
\hline TRA A-77 & $4 / 16 / 90$ & $2,160,000 \pm 30,000$ & $2,260,000 \pm 30,000$ & 2.36 & $\mathbf{N}$ \\
\hline \multirow[t]{2}{*}{ TRA Disp. } & $1 / 18 / 90$ & $6,600 \pm 300$ & $6,500 \pm 300$ & .24 & \\
\hline & $10 / 11 / 90$ & $6,300 \pm 300$ & $6,900 \pm 300$ & 1.41 & \\
\hline \multirow[t]{3}{*}{ TRA 3} & $4 / 27 / 89$ & $-20 \pm 150$ & $70 \pm 160$ & .41 & \\
\hline & $4 / 10 / 92$ & $0 \pm 200$ & $-130 \pm 180$ & .48 & \\
\hline & $11 / 02 / 92$ & $-100 \pm 200$ & $100 \pm 200$ & .71 & \\
\hline \multirow[t]{4}{*}{ TRA 4} & $11 / 13 / 89$ & $10 \pm 150$ & $50 \pm 160$ & .18 & \\
\hline & $4 / 25 / 91$ & $50 \pm 160$ & $50 \pm 160$ & .00 & \\
\hline & $10 / 30 / 91$ & $0 \pm 200$ & $-10 \pm 170$ & .04 & \\
\hline & $4 / 05 / 93$ & $-180 \pm 160$ & $0 \pm 200$ & .70 & \\
\hline USGS 1 & $7 / 20 / 92$ & $0 \pm 200$ & $-190 \pm 170$ & .72 & \\
\hline USGS 8 & $4 / 03 / 91$ & $90 \pm 160$ & $50 \pm 160$ & .18 & \\
\hline USGS 11 & $10 / 08 / 91$ & $110 \pm 170$ & $200 \pm 200$ & .34 & \\
\hline USGS 12 & $6 / 15 / 90$ & $\#$ \# $99.2 \pm 25.6$ & $\# 108.8 \pm 25.6$ & 1.06 & \\
\hline \multirow[t]{2}{*}{ USGS 14} & $10 / 01 / 92$ & $-100 \pm 200$ & $100 \pm 200$ & .71 & \\
\hline & $4 / 16 / 93$ & $-60 \pm 70$ & $-20 \pm 70$ & .40 & \\
\hline \multirow[t]{2}{*}{ USGS 19} & $10 / 12 / 90$ & $-160 \pm 170$ & $-100 \pm 200$ & .23 & \\
\hline & $10 / 01 / 92$ & $0 \pm 200$ & $200 \pm 200$ & .71 & \\
\hline USGS 20 & $4 / 08 / 91$ & $11,300 \pm 400$ & $10,700 \pm 400$ & 1.06 & \\
\hline \multirow[t]{2}{*}{ USGS 22} & $4 / 23 / 91$ & $120 \pm 160$ & $210 \pm 170$ & .39 & \\
\hline & $9 / 30 / 93$ & $-100 \pm 200$ & $140 \pm 180$ & .89 & \\
\hline USGS 23 & $7 / 09 / 93$ & $80 \pm 160$ & $-80 \pm 160$ & .71 & \\
\hline USGS 27 & $4 / 27 / 90$ & $0 \pm 200$ & $-140 \pm 170$ & .53 & \\
\hline USGS 32 & $7 / 06 / 92$ & $0 \pm 200$ & $0 \pm 200$ & .00 & \\
\hline USGS 34 & $4 / 01 / 91$ & $5,100 \pm 300$ & $5500 \pm 300$ & .94 & \\
\hline
\end{tabular}


Table 46. Comparison of the results and standard deviations of replicate pairs of samples from the Idaho National Engineering Laboratory analyzed for tritium by the National Water Quality Laboratory and the Radiological and Environmental Sciences Laboratory-continued

\begin{tabular}{|c|c|c|c|c|c|}
\hline Site identifier & Date sampled & $\begin{array}{l}\text { Tritium } \\
(\mathrm{pCi} / \mathrm{L})\end{array}$ & $\begin{array}{l}\text { Tritium QA } \\
(\mathrm{pCi} / \mathrm{L})\end{array}$ & $Z$-value & Remark \\
\hline \multirow[t]{3}{*}{ USGS 35} & $10 / 07 / 91$ & $7,500 \pm 400$ & $7,600 \pm 400$ & 0.18 & \\
\hline & $4 / 14 / 93$ & $6,300 \pm 300$ & $6,500 \pm 300$ & .47 & \\
\hline & $10 / 23 / 93$ & $5,500 \pm 400$ & ${ }^{\otimes} 5,400 \pm 400$ & .18 & \\
\hline \multirow[t]{3}{*}{ USGS 37} & $1 / 02 / 90$ & $27,800 \pm 700$ & $27,900 \pm 700$ & .10 & \\
\hline & $4 / 18 / 90$ & $25,500 \pm 700$ & $25,400 \pm 700$ & .10 & \\
\hline & $10 / 21 / 93$ & $18,200 \pm 800$ & $18,500 \pm 800$ & .27 & \\
\hline \multirow[t]{2}{*}{ USGS 38} & $4 / 23 / 92$ & $24,600 \pm 700$ & $24,600 \pm 700$ & .00 & \\
\hline & $10 / 14 / 92$ & $21,300 \pm 600$ & $21,100 \pm 600$ & .24 & \\
\hline \multirow[t]{2}{*}{ USGS 40} & $10 / 18 / 89$ & $5,200 \pm 300$ & $5,600 \pm 300$ & .94 & \\
\hline & $4 / 25 / 91$ & $6,600 \pm 300$ & $6,900 \pm 300$ & .71 & \\
\hline USGS 43 & $4 / 13 / 90$ & $4,700 \pm 300$ & $5,300 \pm 300$ & 1.41 & \\
\hline \multirow[t]{2}{*}{ USGS 44} & $10 / 26 / 90$ & $500 \pm 200$ & $600+200$ & .35 & \\
\hline & $11 / 01 / 93$ & $400 \pm 200$ & $500 \pm 200$ & .35 & \\
\hline USGS 45 & $4 / 20 / 92$ & $700 \pm 200$ & $800 \pm 200$ & .35 & \\
\hline USGS 46 & $10 / 09 / 91$ & $3,100 \pm 300$ & $3,200 \pm 300$ & .24 & \\
\hline USGS 47 & $4 / 10 / 91$ & $6,600 \pm 300$ & $7,100 \pm 300$ & 1.18 & \\
\hline USGS 52 & $4 / 03 / 90$ & $2,900 \pm 300$ & $3,100 \pm 300$ & .47 & \\
\hline \multirow[t]{7}{*}{ USGS 54} & 7/07/89 & $4,500 \pm 300$ & $4,500 \pm 300$ & .00 & \\
\hline & $11 / 03 / 89$ & $3,200 \pm 200$ & $3,400 \pm 200$ & .71 & \\
\hline & $1 / 14 / 91$ & $1,400 \pm 200$ & $1,700 \pm 200$ & 1.06 & \\
\hline & $10 / 16 / 92$ & $812,000 \pm 10,000$ & $822,000 \pm 12,000$ & .64 & \\
\hline & $4 / 19 / 93$ & $282,000 \pm 4,000$ & $292,000 \pm 5,000$ & 1.56 & \\
\hline & $7 / 22 / 93$ & $3,900 \pm 300$ & $\otimes_{5,900 \pm 300}$ & 4.71 & $\mathbf{N}$ \\
\hline & $10 / 13 / 93$ & $4,800 \pm 300$ & $4,500 \pm 300$ & .71 & \\
\hline USGS 56 & $11 / 15 / 89$ & $645,000 \pm 1,000$ & $643,000 \pm 1,000$ & 1.41 & \\
\hline \multirow[t]{4}{*}{ USGS 57} & $12 / 22 / 89$ & $22,500 \pm 600$ & $22,800 \pm 600$ & .35 & \\
\hline & $6 / 28 / 90$ & $24,000 \pm 700$ & $24,500 \pm 700$ & .51 & \\
\hline & $10 / 29 / 90$ & $26,000 \pm 700$ & $26,000 \pm 700$ & .00 & \\
\hline & $7 / 21 / 93$ & $18,500 \pm 600$ & ${ }^{\otimes} 17,900 \pm 500$ & .77 & \\
\hline \multirow[t]{2}{*}{ USGS 58} & $4 / 03 / 91$ & $5,100 \pm 300$ & $5,300 \pm 300$ & .47 & \\
\hline & $10 / 21 / 93$ & $3,900 \pm 300$ & $4,100 \pm 300$ & .47 & \\
\hline \multirow[t]{4}{*}{ USGS 59} & $4 / 17 / 89$ & $3,100 \pm 200$ & $3,100 \pm 200$ & .00 & \\
\hline & $4 / 28 / 92$ & $5,200 \pm 300$ & $5,100+300$ & .24 & \\
\hline & $4 / 22 / 93$ & $8,100 \pm 400$ & $8,300 \pm 400$ & .35 & \\
\hline & $10 / 25 / 93$ & $3,400 \pm 300$ & $3,000 \pm 300$ & .94 & . \\
\hline \multirow[t]{2}{*}{ USGS 60} & $10 / 30 / 89$ & $110 \pm 160$ & $160 \pm 160$ & .22 & \\
\hline & $1 / 10 / 92$ & $130,000 \pm 2,000$ & $133,000 \pm 2,000$ & 1.06 & \\
\hline USGS 61 & $9 / 27 / 90$ & $14,700 \pm 500$ & $15,200 \pm 500$ & .71 & \\
\hline
\end{tabular}


Table 46. Comparison of the results and standard deviations of replicate pairs of samples from the Idaho National Engineering Laboratory analyzed for tritium by the National Water Quality Laboratory and the Radiological and Environmental Sciences Laboratory-continued

\begin{tabular}{|c|c|c|c|c|c|}
\hline Site identifier & Date sampled & $\begin{array}{l}\text { Tritium } \\
(\mathrm{pCi} / \mathrm{L})\end{array}$ & $\begin{array}{l}\text { Tritium QA } \\
(\mathrm{pCi} / \mathrm{L})\end{array}$ & Z-value & Remark \\
\hline \multirow[t]{2}{*}{ USGS 62} & $4 / 09 / 92$ & $7,200 \pm 400$ & $7,700 \pm 400$ & 0.88 & \\
\hline & $10 / 13 / 92$ & $4,800 \pm 300$ & $5,000 \pm 300$ & .47 & \\
\hline USGS 63 & $4 / 10 / 90$ & $100 \pm 180$ & $130 \pm 180$ & .12 & \\
\hline USGS 65 & $10 / 15 / 91$ & $37,800 \pm 900$ & $37,900 \pm 900$ & .08 & \\
\hline USGS 66 & $4 / 29 / 92$ & $6,700 \pm 400$ & $7,000 \pm 400$ & .53 & \\
\hline \multirow[t]{3}{*}{ USGS 68} & $4 / 27 / 89$ & $10 \pm 150$ & $200 \pm 160$ & .87 & \\
\hline & $7 / 02 / 91$ & $-50 \pm 160$ & $110 \pm 170$ & .69 & \\
\hline & $1 / 17 / 92$ & $-160 \pm 180$ & $-110 \pm 180$ & .20 & \\
\hline USGS 69 & $10 / 24 / 91$ & $20 \pm 170$ & $140 \pm 170$ & .50 & \\
\hline \multirow[t]{2}{*}{ USGS 71} & $4 / 22 / 91$ & $13,300 \pm 500$ & $1,2600 \pm 500$ & .99 & \\
\hline & $10 / 12 / 93$ & $7,100 \pm 400$ & $7,200 \pm 400$ & .18 & \\
\hline USGS 72 & $10 / 28 / 93$ & $-100 \pm 200$ & $-100 \pm 200$ & .00 & \\
\hline \multirow[t]{4}{*}{ USGS 76} & $1 / 05 / 90$ & $2,900 \pm 200$ & $2,700 \pm 200$ & .71 & \\
\hline & $10 / 17 / 90$ & $3,200 \pm 300$ & $3,400 \pm 300$ & .47 & \\
\hline & $4 / 26 / 93$ & $2,700 \pm 200$ & $2,800 \pm 300$ & .28 & \\
\hline & $10 / 22 / 93$ & $2,300 \pm 300$ & $\otimes_{2,600 \pm 300}$ & .71 & \\
\hline USGS 77 & $10 / 09 / 92$ & $36,800 \pm 900$ & $35,800 \pm 900$ & .79 & \\
\hline \multirow[t]{2}{*}{ USGS 82} & $4 / 15 / 92$ & $120 \pm 190$ & $-120 \pm 180$ & .92 & \\
\hline & $7 / 07 / 93$ & $110 \pm 160$ & $130 \pm 160$ & .09 & \\
\hline \multirow[t]{2}{*}{ USGS 83} & $10 / 11 / 90$ & $200 \pm 200$ & $0 \pm 200$ & .71 & \\
\hline & $4 / 06 / 92$ & $-100 \pm 180$ & $-150 \pm 180$ & .20 & \\
\hline USGS 84 & $10 / 09 / 92$ & $5,700 \pm 300$ & $5,600 \pm 300$ & .24 & \\
\hline \multirow[t]{2}{*}{ USGS 85} & $4 / 26 / 90$ & $22,800 \pm 600$ & $22,500 \pm 600$ & .35 & \\
\hline & $4 / 19 / 93$ & $15,000 \pm 500$ & $15,600 \pm 500$ & .85 & \\
\hline \multirow[t]{2}{*}{ USGS 86} & $4 / 21 / 89$ & $10 \pm 150$ & $-40 \pm 150$ & .24 & \\
\hline & $10 / 13 / 93$ & $60 \pm 80$ & $-60 \pm 80$ & 1.06 & \\
\hline USGS 87 & $4 / 21 / 92$ & $1,000 \pm 200$ & $1,100 \pm 200$ & .35 & \\
\hline \multirow[t]{3}{*}{ USGS 88} & $7 / 12 / 89$ & $20 \pm 160$ & $-10 \pm 160$ & .13 & \\
\hline & $7 / 16 / 91$ & $-120 \pm 160$ & $110 \pm 170$ & .99 & \\
\hline & $1 / 20 / 93$ & $0 \pm 200$ & $0 \pm 200$ & .00 & \\
\hline \multirow[t]{3}{*}{ USGS 89} & $1 / 04 / 89$ & $50 \pm 160$ & $-60 \pm 160$ & .49 & \\
\hline & $10 / 16 / 91$ & $-50 \pm 170$ & $0 \pm 170$ & .21 & \\
\hline & $1 / 17 / 92$ & $-300 \pm 200$ & $-100 \pm 200$ & .71 & \\
\hline \multirow[t]{5}{*}{ USGS 90} & $1 / 18 / 89$ & $1,900 \pm 200$ & $1,600 \pm 200$ & 1.06 & \\
\hline & $1 / 23 / 90$ & $1,300 \pm 200$ & $1,300 \pm 200$ & .00 & \\
\hline & $1 / 16 / 92$ & $1,500 \pm 200$ & $1,400 \pm 200$ & .35 & \\
\hline & $4 / 20 / 92$ & $1,400 \pm 200$ & $1,200 \pm 200$ & .71 & \\
\hline & $10 / 04 / 93$ & $1,400 \pm 200$ & $1,100 \pm 200$ & 1.06 & \\
\hline
\end{tabular}


Table 46. Comparison of the results and standard deviations of replicate pairs of samples from the Idaho National Engineering Laboratory analyzed for tritium by the National Water Quality Laboratory and the Radiological and Environmental Sciences Laboratory-continued

\begin{tabular}{|c|c|c|c|c|c|}
\hline Site identifier & Date sampled & $\begin{array}{l}\text { Tritium } \\
(\mathrm{pCi} / \mathrm{L})\end{array}$ & $\begin{array}{c}\text { Tritium QA } \\
(\mathrm{pCi} / \mathrm{L})\end{array}$ & Z-value & Remark \\
\hline \multirow[t]{3}{*}{ USGS 100} & $1 / 07 / 91$ & $-100 \pm 200$ & $-140 \pm 180$ & 0.15 & \\
\hline & $10 / 05 / 92$ & $-100 \pm 200$ & $100 \pm 180$ & .74 & \\
\hline & $4 / 23 / 93$ & $-150 \pm 170$ & $-210 \pm 160$ & .26 & \\
\hline USGS 103 & $7 / 16 / 93$ & $70 \pm 160$ & $-60 \pm 160$ & .57 & \\
\hline \multirow[t]{4}{*}{ USGS 104} & $10 / 16 / 89$ & $1,500 \pm 200$ & $1,400 \pm 200$ & .35 & \\
\hline & $7 / 09 / 90$ & $1,800 \pm 200$ & $1,700 \pm 200$ & .35 & \\
\hline & $1 / 10 / 91$ & $1,700 \pm 200$ & $1,700 \pm 200$ & .00 & \\
\hline & $9 / 29 / 92$ & $1,720 \pm 110$ & $1,540 \pm 100$ & 1.21 & \\
\hline USGS 105 & $10 / 25 / 89$ & $80 \pm 70$ & $150 \pm 70$ & .71 & \\
\hline \multirow[t]{2}{*}{ USGS 106} & $4 / 02 / 90$ & $2,200 \pm 200$ & $2,100 \pm 200$ & .35 & \\
\hline & $4 / 02 / 92$ & $2,000 \pm 200$ & $1,900 \pm 200$ & .35 & \\
\hline \multirow[t]{2}{*}{ USGS 107} & $4 / 22 / 91$ & $-70 \pm 160$ & $10 \pm 160$ & .35 & \\
\hline & $4 / 21 / 93$ & $-220 \pm 160$ & $-60 \pm 170$ & .69 & \\
\hline USGS 109 & $10 / 01 / 93$ & $120 \pm 80$ & $120 \pm 80$ & .00 & \\
\hline \multirow[t]{2}{*}{ USGS 110} & $4 / 12 / 89$ & $-60 \pm 150$ & $10 \pm 150$ & .33 & \\
\hline & $10 / 11 / 89$ & $-100 \pm 150$ & $0 \pm 150$ & .47 & \\
\hline USGS 111 & $3 / 20 / 90$ & $27,100 \pm 700$ & $27,500 \pm 700$ & .40 & \\
\hline USGS 113 & $7 / 15 / 91$ & $30,800 \pm 800$ & $30,500 \pm 800$ & .27 & \\
\hline \multirow[t]{3}{*}{ USGS 114} & $10 / 05 / 89$ & $29,000 \pm 700$ & $28,800 \pm 700$ & .20 & \\
\hline & $9 / 24 / 90$ & $30,500 \pm 800$ & $30,400 \pm 800$ & .09 & \\
\hline & $10 / 21 / 91$ & $29,000 \pm 700$ & $29,300 \pm 800$ & .28 & \\
\hline USGS 115 & $7 / 16 / 93$ & $4,700 \pm 300$ & $4,400 \pm 300$ & .71 & \\
\hline \multirow[t]{2}{*}{ USGS 116} & $4 / 06 / 89$ & $14,100 \pm 500$ & $13,700+500$ & .57 & \\
\hline & $10 / 05 / 89$ & $11,200 \pm 400$ & $11,500 \pm 400$ & .53 & \\
\hline USGS 117 & $4 / 18 / 91$ & $100 \pm 160$ & $110 \pm 160$ & .04 & \\
\hline \multirow[t]{4}{*}{ USGS 119} & $4 / 03 / 89$ & $-70 \pm 150$ & $-20 \pm 150$ & .24 & \\
\hline & $6 / 28 / 89$ & $80 \pm 160$ & $40 \pm 160$ & .18 & \\
\hline & $4 / 09 / 90$ & $-200 \pm 200$ & $-100 \pm 200$ & .35 & \\
\hline & $7 / 09 / 92$ & $0 \pm 200$ & $0 \pm 200$ & .00 & \\
\hline USGS 120 & $7 / 19 / 90$ & $130 \pm 180$ & $140 \pm 180$ & .04 & \\
\hline \multirow[t]{2}{*}{ USGS 122} & $10 / 15 / 91$ & $22,400 \pm 600$ & $21,700 \pm 600$ & .82 & \\
\hline & $4 / 15 / 92$ & $20,400 \pm 600$ & $20,600 \pm 600$ & .24 & \\
\hline
\end{tabular}


Table 47. Comparison of the results and standard deviations of replicate pairs of samples from the Idaho National Engineering Laboratory analyzed for americium-241 by the Radiological and Environmental Sciences Laboratory

[Site identifier: see figures 1-3 for location of sites. QA: quality-assurance replicate sample. Z-value: see section on Statistical Comparisons of Replicate Pairs of Samples for explanation. Remark: the results of replicate pairs are statistically equivalent. Abbreviations: $\mathrm{pCi} / \mathrm{L}$, picocurie per liter]

\begin{tabular}{lccccc}
\hline Site identifier & Date sampled & $\begin{array}{c}\text { Americium-241 } \\
(\mathrm{pCi} / \mathrm{L})\end{array}$ & $\begin{array}{c}\text { Americium-241 } \\
\text { QA }(\mathrm{pCi} / \mathrm{L})\end{array}$ & Z-value & Remark \\
\hline RWMC Prod. & $10 / 30 / 90$ & $0.06 \pm 0.05$ & $0.02 \pm 0.03$ & 0.69 \\
USGS 37 & $10 / 21 / 93$ & $.016 \pm 0.018$ & $.00 \pm 0.02$ & .59 \\
USGS 40 & $10 / 18 / 89$ & $.01 \pm 0.12$ & $.04 \pm 0.04$ & .24 \\
USGS 44 & $10 / 26 / 90$ & $-.04 \pm 0.03$ & $-.03 \pm 0.03$ & .24 \\
USGS 87 & $4 / 21 / 92$ & $.00 \pm 0.02$ & $.02 \pm 0.03$ & .55 \\
USGS 88 & $7 / 12 / 89$ & $.00 \pm 0.03$ & $.07 \pm 0,03$ & 1.65 \\
& $7 / 16 / 91$ & $-.06 \pm 0.03$ & $.00 \pm 0.02$ & 1.66 \\
& $1 / 20 / 93$ & $.05 \pm 0.03$ & $.00 \pm 0.03$ & 1.18 \\
USGS 89 & $1 / 04 / 89$ & $.03 \pm 0.03$ & $.03 \pm 0.03$ & .00 \\
& $10 / 16 / 91$ & $.00 \pm 0.02$ & $-.015 \pm 0.025$ & .47 \\
USGS 90 & $1 / 18 / 89$ & $-.04 \pm 0.03$ & $-.04 \pm 0.03$ & .00 \\
& $1 / 23 / 90$ & $.00 \pm 0.03$ & $.011 \pm 0.033$ & .25 \\
& $1 / 16 / 92$ & $.03 \pm 0.02$ & $.013 \pm 0.022$ & .57 \\
& $4 / 20 / 92$ & $.00 \pm 0.02$ & $.02 \pm 0.02$ & .71 \\
USGS 120 & $10 / 04 / 93$ & $.00 \pm 0.02$ & $.01 \pm 0.02$ & .37 \\
\hline USGS 117 & $4 / 18 / 91$ & $-.005 \pm 0.017$ & $.01 \pm 0.03$ & .44 \\
USGS 119 & $4 / 03 / 89$ & $.03 \pm 0.03$ & $-.01 \pm 0.02$ & 1.11 \\
& $4 / 09 / 90$ & $.02 \pm 0.03$ & $-.01 \pm 0.02$ & .83 \\
& $7 / 19 / 90$ & $-.014 \pm 0.033$ & $.03 \pm 0.03$ & .99 \\
\end{tabular}


Table 48. Comparison of the results and standard deviations of replicate pairs of samples from the Idaho National Engineering Laboratory analyzed for plutonium-238 by the Radiological and Environmental Sciences Laboratory

[Site identifier: see figures 1-3 for location of sites. QA: quality-assurance replicate sample. Z-value: see section on Statistical Comparisons of Replicate Pairs of Samples for explanation. Abbreviations: pCi/L, picocurie per liter; N, the analytical results are not in statistical agreement]

\begin{tabular}{lcccrc}
\hline Site identifier & Date sampled & $\begin{array}{c}\text { Plutonium-238 } \\
(\mathrm{pCi} / \mathrm{L})\end{array}$ & $\begin{array}{c}\text { Plutonium-238 QA } \\
(\mathrm{pCi} / \mathrm{L})\end{array}$ & Z-value & Remark \\
\hline RWMC Prod. & $10 / 30 / 90$ & $0.03 \pm 0.03$ & $0.02 \pm 0.02$ & 0.28 \\
USGS 37 & $10 / 21 / 93$ & $-.001 \pm 0.014$ & $.003 \pm 0.012$ & .22 \\
USGS 40 & $10 / 18 / 89$ & $-.017 \pm 0.017$ & $.016 \pm 0.017$ & 1.37 \\
USGS 44 & $10 / 26 / 90$ & $.010 \pm 0.019$ & $-.01 \pm 0.02$ & .72 \\
USGS 87 & $4 / 21 / 92$ & $-.04 \pm 0.03$ & $-.011 \pm 0.025$ & .74 \\
USGS 88 & $7 / 12 / 89$ & $-.016 \pm 0.023$ & $-.04 \pm 0.02$ & .79 \\
& $7 / 16 / 91$ & $.0 \pm 0.03$ & $.03 \pm 0.03$ & .71 \\
& $1 / 20 / 93$ & $.016 \pm 0.020$ & $.00 \pm 0.02$ & .57 \\
USGS 89 & $1 / 04 / 89$ & $-.04 \pm 0.03$ & $-.013 \pm 0.032$ & .62 \\
& $10 / 16 / 91$ & $.01 \pm 0.02$ & $-.011 \pm 0.017$ & .80 \\
USGS 90 & $1 / 18 / 89$ & $-.04 \pm 0.03$ & $-.05 \pm 0.03$ & .24 \\
& $1 / 23 / 90$ & $.02 \pm 0.02$ & $.00 \pm 0.02$ & .71 \\
& $1 / 16 / 92$ & $.00 \pm 0.02$ & $.00 \pm 0.02$ & .00 \\
& $4 / 20 / 92$ & $.00 \pm 0.03$ & $-.012 \pm 0.025$ & .31 \\
USGS 120 & $10 / 04 / 93$ & $.010 \pm 0.015$ & $.003 \pm 0.012$ & .36 \\
& $4 / 18 / 91$ & $.01 \pm 0.02$ & $-.02 \pm 0.03$ & .83 \\
USGS 117 & $4 / 03 / 89$ & $.10 \pm 0.04$ & $-.011 \pm 0.023$ & 2.41 \\
USGS 119 & $4 / 09 / 90$ & $-.015 \pm 0.014$ & $.015 \pm 0.021$ & 1.19 \\
& $7 / 19 / 90$ & $-.04 \pm 0.03$ & $-.015 \pm 0.035$ & .54 \\
\hline
\end{tabular}


Table 49. Comparison of the results and standard deviations of replicate pairs of samples from the Idaho National Engineering Laboratory analyzed for plutonium-239/240 by the Radiological and Environmental Sciences Laboratory

Site identifier: see figures 1-3 for location of sites. QA: quality-assurance replicate sample. Z-value: see section on Statistical Comparisons of Replicate Pairs of Samples for explanation. Abbreviations: $p C i / L$, picocurie per liter; $N$, the analytical results are not in statistical agreement]

\begin{tabular}{|c|c|c|c|c|c|}
\hline Site identifier & Date sampled & $\begin{array}{l}\text { Plutonium-239/240 } \\
\qquad(\mathrm{pCi} / \mathrm{L})\end{array}$ & $\begin{array}{l}\text { Plutonium-239/240 } \\
\text { QA (pCi/L) }\end{array}$ & $\mathrm{Z}$-value & Remark \\
\hline RWMC Prod. & $10 / 30 / 90$ & $0.00 \pm 0.02$ & $-0.017 \pm 0.013$ & 0.71 & \\
\hline USGS 37 & $10 / 21 / 93$ & $-.011 \pm 0.011$ & $-.004 \pm 0.013$ & .41 & \\
\hline USGS 40 & $10 / 18 / 89$ & $.005 \pm 0.014$ & $-.007 \pm 0.017$ & .54 & \\
\hline USGS 44 & $10 / 26 / 90$ & $-.001 \pm 0.011$ & $-.005 \pm 0.014$ & .22 & \\
\hline USGS 87 & $4 / 21 / 92$ & $.011 \pm 0.017$ & $.00 \pm 0.02$ & .42 & \\
\hline \multirow[t]{3}{*}{ USGS 88} & $7 / 12 / 89$ & $-.001 \pm 0.016$ & $-.001 \pm 0.015$ & .00 & \\
\hline & $7 / 16 / 91$ & $-.014 \pm 0.014$ & $-.025 \pm 0.015$ & .54 & \\
\hline & $1 / 20 / 93$ & $.006 \pm 0.012$ & $.015 \pm 0.015$ & .47 & \\
\hline \multirow[t]{2}{*}{ USGS 89} & $1 / 04 / 89$ & $.00 \pm 0.02$ & $-.020 \pm 0.016$ & .78 & \\
\hline & $10 / 16 / 91$ & $-.004 \pm 0.013$ & $-.001 \pm 0.01$ & .18 & \\
\hline \multirow[t]{5}{*}{ USGS 90} & $1 / 18 / 89$ & $-.01 \pm 0.02$ & $-.015 \pm 0.019$ & .18 & \\
\hline & $1 / 23 / 90$ & $-.001 \pm 0.015$ & $.015 \pm 0.024$ & .57 & \\
\hline & $1 / 16 / 92$ & $-.004 \pm 0.011$ & $-.009 \pm 0.012$ & .31 & \\
\hline & $4 / 20 / 92$ & $-.002 \pm 0.016$ & $.00 \pm 0.02$ & .08 & \\
\hline & $10 / 04 / 93$ & $.003 \pm 0.015$ & $.000 \pm 0.012$ & .16 & \\
\hline USGS 117 & $4 / 18 / 91$ & $.010 \pm 0.023$ & $.016 \pm 0.023$ & .18 & \\
\hline \multirow[t]{2}{*}{ USGS 119} & $4 / 03 / 89$ & $-.08 \pm 0.03$ & $.004 \pm 0.016$ & 2.47 & $\mathrm{~N}$ \\
\hline & $4 / 09 / 90$ & $-.002 \pm 0.012$ & $-.009 \pm 0.016$ & .35 & \\
\hline USGS 120 & $7 / 19 / 90$ & $.00 \pm 0.02$ & $-.011 \pm 0.020$ & .39 & \\
\hline
\end{tabular}


Table 50. Comparison of results of replicate pairs of samples from the Idaho National Engineering Laboratory analyzed for total organic carbon by the National Water Quality Laboratory

[Site identifier: see figures 1-3 for location of sites. QA: quality-assurance replicate sample. Z-value: see section on Statistical Comparisons of Replicate Pairs of Samples for explanation. Abbreviations: $\mathrm{mg} / \mathrm{L}$, milligram per liter; $\mathrm{N}$, the analytical results are not in statistical agreement. Symbol: <, the result was less than the indicated reporting level]

\begin{tabular}{|c|c|c|c|c|c|}
\hline Site identifier & Date sampled & $\begin{array}{l}\text { Total organic } \\
\text { carbon } \\
(\mathrm{mg} / \mathrm{L})\end{array}$ & $\begin{array}{l}\text { Total organic } \\
\text { carbon QA } \\
\text { (mg/L) }\end{array}$ & $Z$-value & Remark \\
\hline NRF-1 & $9 / 09 / 91$ & 0.4 & 0.4 & 0.00 & \\
\hline \multirow[t]{3}{*}{ NRF-2 } & $3 / 21 / 90$ & .4 & .3 & .48 & \\
\hline & $3 / 05 / 91$ & .5 & .4 & .48 & \\
\hline & 9/15/93 & .5 & 1.8 & 6.37 & $\mathbf{N}$ \\
\hline \multirow[t]{2}{*}{ NRF-3 } & $6 / 17 / 91$ & 1.8 & .5 & 6.37 & $\mathbf{N}$ \\
\hline & $12 / 03 / 92$ & .7 & .7 & .00 & \\
\hline \multirow[t]{2}{*}{ NRF-4 } & $2 / 07 / 91$ & .3 & .3 & .00 & \\
\hline & $4 / 07 / 93$ & 1.0 & .5 & 2.43 & $\mathbf{N}$ \\
\hline NRF-6 & $3 / 10 / 92$ & 6 & .5 & .48 & \\
\hline NRF-7 & $1 / 08 / 92$ & .6 & .5 & .48 & \\
\hline \multirow[t]{2}{*}{ WSINEL1 } & $12 / 07 / 90$ & 1.0 & 1.6 & 2.95 & $\mathbf{N}$ \\
\hline & $12 / 03 / 91$ & .9 & .7 & .97 & \\
\hline \multirow[t]{3}{*}{ USGS 12} & $6 / 15 / 90$ & .3 & .3 & .00 & \\
\hline & $09 / 06 / 91$ & .4 & .4 & .00 & \\
\hline & $11 / 05 / 93$ & .4 & .6 & .97 & \\
\hline \multirow[t]{2}{*}{ USGS 15} & $8 / 06 / 90$ & 1.5 & 2.2 & 3.48 & $\mathbf{N}$ \\
\hline & $3 / 12 / 92$ & $<.1$ & .2 & .96 & \\
\hline \multirow[t]{2}{*}{ USGS 17} & $3 / 13 / 91$ & .1 & .4 & 1.44 & \\
\hline & $6 / 11 / 93$ & .1 & .5 & 1.93 & \\
\hline \multirow[t]{3}{*}{ USGS 97} & $12 / 07 / 90$ & .3 & .4 & .48 & \\
\hline & $6 / 07 / 91$ & .3 & .4 & .48 & \\
\hline & $11 / 04 / 93$ & .4 & .5 & .48 & \\
\hline \multirow[t]{2}{*}{ USGS 98} & $7 / 30 / 90$ & .2 & .3 & .48 & \\
\hline & $9 / 21 / 92$ & .5 & .5 & .00 & \\
\hline \multirow[t]{2}{*}{ USGS 99} & $10 / 03 / 90$ & .4 & .4 & .00 & \\
\hline & $6 / 16 / 92$ & .3 & .4 & .48 & \\
\hline \multirow[t]{2}{*}{ USGS 102} & $12 / 10 / 90$ & .4 & .3 & .48 & \\
\hline & $12 / 09 / 92$ & .4 & .4 & .00 & \\
\hline
\end{tabular}


Table 51. Comparison of results of replicate pairs of samples from the Idaho National Engineering Laboratory analyzed for volatile organic compounds by the National Water Quality Laboratory

[Site identifier: see figures 1-3 for location of sites. For each compound, the result of the routine sample is followed by the result of the quality-assurance replicate sample. Z-value: see section on Statistical Comparisons of Replicate Pairs of Samples for explanation. Abbreviations: $\mu \mathrm{g} / \mathrm{L}$, microgram per liter. Symbol: <, the result was less than the indicated reporting level. Numbers in bold indicate the results are above their respective reporting limits]

\begin{tabular}{|c|c|c|c|c|c|c|c|c|c|c|c|c|c|}
\hline Site identifier & $\begin{array}{c}\text { Date } \\
\text { sampled }\end{array}$ & 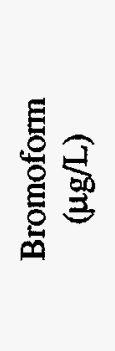 & 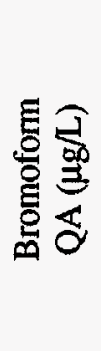 & $\mathrm{Z}$-value & Remark & 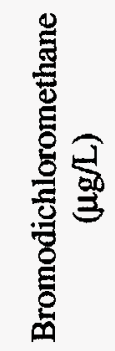 & 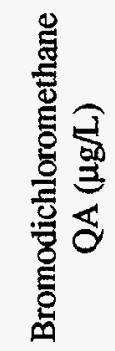 & $Z$-value & Remark & 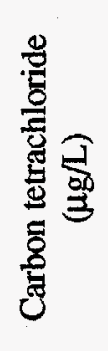 & 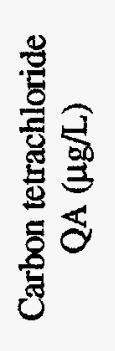 & $Z$-value & Remark \\
\hline RWMC Prod. & $10 / 30 / 90$ & $<0.2$ & $<0.2$ & 0 & & $<0.2$ & $<0.2$ & 0 & & 1.7 & 1.7 & 0.00 & \\
\hline USGS 12 & $6 / 15 / 90$ & $<.2$ & $<.2$ & 0 & & $<.2$ & $<.2$ & 0 & & $<.2$ & $<.2$ & 0 & \\
\hline USGS 44 & $10 / 26 / 90$ & $<.2$ & $<.2$ & 0 & & $<.2$ & $<.2$ & 0 & & $<.2$ & $<.2$ & 0 & \\
\hline \multirow{4}{*}{$\begin{array}{l}\text { USGS } 87 \\
\text { USGS } 88\end{array}$} & $4 / 21 / 92$ & $<.2$ & $<.2$ & 0 & & $<.2$ & $<.2$ & 0 & & .9 & .8 & 1.28 & \\
\hline & $7 / 12 / 89$ & $<.2$ & $<.2$ & 0 & & $<.2$ & $<.2$ & 0 & & 1.0 & 1.1 & 1.03 & \\
\hline & $7 / 16 / 91$ & $<.2$ & $<.2$ & 0 & & $<.2$ & $<.2$ & 0 & & 1.6 & 1.8 & 1.28 & \\
\hline & $1 / 20 / 93$ & $<.2$ & $<.2$ & 0 & & $<.2$ & $<.2$ & 0 & & 2.4 & 2.3 & .46 & \\
\hline \multirow[t]{2}{*}{ USGS 89} & $1 / 04 / 89$ & $<.2$ & $<.2$ & 0 & & $<.2$ & $<.2$ & 0 & & $<.2$ & $<.2$ & 0 & \\
\hline & $10 / 16 / 91$ & $<.2$ & $<.2$ & 0 & & $<.2$ & $<.2$ & 0 & & $<.2$ & $<.2$ & 0 & \\
\hline \multirow[t]{5}{*}{ USGS 90} & $1 / 18 / 89$ & $<.2$ & $<.2$ & 0 & & $<.2$ & $<.2$ & 0 & & .9 & .9 & .00 & \\
\hline & $1 / 23 / 90$ & $<.2$ & $<.2$ & 0 & & $<.2$ & $<.2$ & 0 & & 1.0 & .9 & 1.14 & \\
\hline & $1 / 16 / 92$ & $<.2$ & .6 & 4.52 & $\mathbf{N}$ & $<.2$ & .9 & 4.30 & $\mathbf{N}$ & 1.1 & 1.1 & .00 & \\
\hline & $4 / 20 / 92$ & $<.2$ & $<.2$ & 0 & & $<.2$ & $<.2$ & 0 & & 1.2 & 1.3 & .87 & \\
\hline & $10 / 04 / 93$ & $<.2$ & $<.2$ & 0 & & $<.2$ & $<.2$ & 0 & & 1.3 & 1.3 & .00 & \\
\hline USGS 117 & $4 / 18 / 91$ & $<.2$ & $<.2$ & 0 & & $<.2$ & $<.2$ & 0 & & $<.2$ & $<.2$ & 0 & \\
\hline \multirow[t]{2}{*}{ USGS 119} & $4 / 03 / 89$ & $<.2$ & $<.2$ & 0 & & $<.2$ & $<.2$ & 0 & & $<.2$ & $<.2$ & 0 & \\
\hline & $4 / 09 / 90$ & $<.2$ & $<.2$ & 0 & & $<.2$ & $<.2$ & 0 & & $<.2$ & $<.2$ & 0 & \\
\hline USGS 120 & $7 / 19 / 90$ & $<.2$ & $<.2$ & 0 & & $<.2$ & $<.2$ & 0 & & 1.0 & 1.1 & .80 & \\
\hline
\end{tabular}


Table 51. Comparison of results of replicate pairs of samples from the Idaho National Engineering Laboratory analyzed for volatile organic compounds by the National Water Quality Laboratory-continued

\begin{tabular}{|c|c|c|c|c|c|c|c|c|c|c|c|c|c|}
\hline Site identifier & $\begin{array}{c}\text { Date } \\
\text { sampled }\end{array}$ & $\begin{array}{l}\text { 통 } \\
\text { 응 } \\
\text { 월 }\end{array}$ & 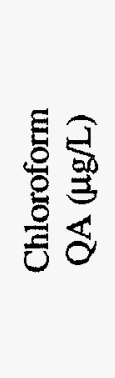 & $\mathrm{Z}$-value & Remark & 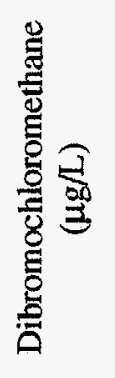 & 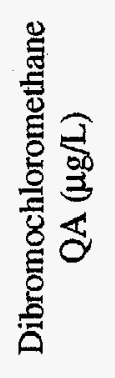 & $Z$-value & Remark & 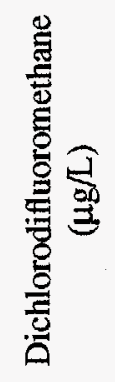 & 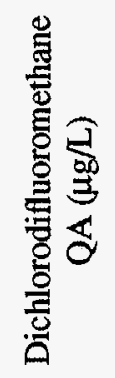 & Z-value & Remark \\
\hline RWMC Prod. & $10 / 30 / 90$ & $<0.2$ & $<0.2$ & $\overline{0}$ & & $<0.2$ & $<0.2$ & 0 & & $<0.2$ & $<0.2$ & 0 & \\
\hline USGS 12 & $6 / 15 / 90$ & $<.2$ & $<.2$ & 0 & & $<.2$ & $<.2$ & 0 & & $<.2$ & $<.2$ & 0 & \\
\hline USGS 44 & $10 / 26 / 90$ & $<.2$ & $<.2$ & 0 & & $<.2$ & $<.2$ & 0 & & $<.2$ & $<.2$ & 0 & \\
\hline USGS 87 & $4 / 21 / 92$ & $<.2$ & $<.2$ & 0 & & $<.2$ & $<.2$ & 0 & & $<.2$ & $<.2$ & 0 & \\
\hline \multirow[t]{3}{*}{ USGS 88} & $7 / 12 / 89$ & .4 & .4 & .00 & & $<.2$ & $<.2$ & 0 & , & 1.0 & 1.1 & .61 & \\
\hline & $7 / 16 / 91$ & .4 & .4 & .00 & & $<.2$ & $<.2$ & 0 & & $<.2$ & $<.2$ & 0 & \\
\hline & $1 / 20 / 93$ & .5 & .6 & 1.16 & & $<.2$ & $<.2$ & 0 & & $<.2$ & $<.2$ & 0 & \\
\hline \multirow[t]{2}{*}{ USGS 89} & $1 / 04 / 89$ & $<.2$ & $<.2$ & 0 & & $<.2$ & $<.2$ & 0 & & $<.2$ & $<.2$ & 0 & \\
\hline & $10 / 16 / 91$ & $<.2$ & $<.2$ & 0 & & $<.2$ & $<.2$ & 0 & & .2 & $<.2$ & & $U$ \\
\hline \multirow[t]{5}{*}{ USGS 90} & $1 / 18 / 89$ & $<.2$ & $<.2$ & 0 & & $<.2$ & $<.2$ & 0 & & .2 & .3 & 2.52 & $\mathrm{~N}$ \\
\hline & $1 / 23 / 90$ & $<.2$ & $<.2$ & 0 & & $<.2$ & $<.2$ & 0 & & $<.2$ & $<.2$ & 0 & \\
\hline & $1 / 16 / 92$ & $<.2$ & 1.2 & 7.47 & $\mathrm{~N}$ & $<.2$ & .9 & 6.90 & $\mathrm{~N}$ & .4 & .5 & 1.42 & \\
\hline & $4 / 20 / 92$ & $<.2$ & $<.2$ & 0 & & $<.2$ & $<.2$ & 0 & & .3 & .3 & .00 & \\
\hline & $10 / 04 / 93$ & $<.2$ & $<.2$ & 0 & & $<.2$ & $<.2$ & 0 & & $<.2$ & $<.2$ & 0 & \\
\hline USGS 117 & $4 / 18 / 91$ & $<.2$ & $<.2$ & 0 & & $<.2$ & $<.2$ & 0 & & $<.2$ & $<.2$ & 0 & \\
\hline \multirow[t]{2}{*}{ USGS 119} & $4 / 03 / 89$ & $<.2$ & $<.2$ & 0 & & $<.2$ & $<.2$ & 0 & & $<.2$ & $<.2$ & 0 & \\
\hline & $4 / 09 / 90$ & $<.2$ & $<.2$ & 0 & & $<.2$ & $<.2$ & 0 & & $<.2$ & $<.2$ & 0 & \\
\hline USGS 120 & $7 / 19 / 90$ & $<.2$ & $<.2$ & 0 & & $<.2$ & $<.2$ & 0 & & $<.2$ & $<.2$ & 0 & \\
\hline
\end{tabular}


Table 51. Comparison of results of replicate pairs of samples from the Idaho National Engineering Laboratory analyzed for volatile organic compounds by the National Water Quality Laboratory-continued

\begin{tabular}{|c|c|c|c|c|c|c|c|c|c|c|c|c|c|}
\hline Site Identifier & $\begin{array}{c}\text { Date } \\
\text { sampled }\end{array}$ & 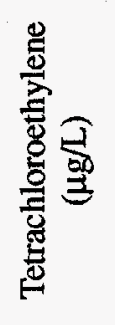 & 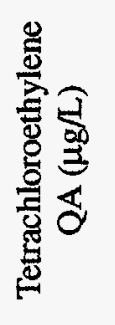 & Z-value & Remark & 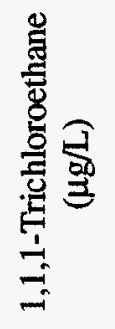 & 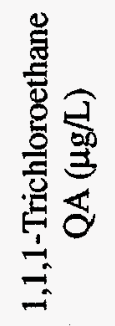 & $Z$-value & Remark & 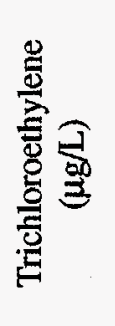 & 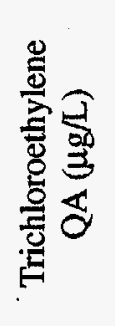 & $Z$-value & Remark \\
\hline RWMC Prod. & $10 / 30 / 90$ & 0.2 & $<0.2$ & & $\bar{U}$ & 0.4 & 0.4 & 0.00 & & 0.8 & 0.8 & 0.00 & \\
\hline USGS 12 & $6 / 15 / 90$ & $<.2$ & $<.2$ & 0 & & $<.2$ & $<.2$ & 0 & & $<.2$ & $<.2$ & 0 & \\
\hline USGS 44 & $10 / 26 / 90$ & $<.2$ & $<.2$ & 0 & & .2 & .3 & 2.31 & $\mathrm{~N}$ & $<.2$ & $<.2$ & 0 & \\
\hline USGS 87 & $4 / 21 / 92$ & $<.2$ & $<.2$ & 0 & & .2 & $<.2$ & 0 & & .2 & .2 & .00 & \\
\hline USGS 88 & $7 / 12 / 89$ & $<.2$ & .2 & & $\mathrm{U}$ & .2 & .2 & .00 & & .5 & .6 & .98 & \\
\hline & $7 / 16 / 91$ & $<.2$ & $<.2$ & 0 & & .3 & .3 & .00 & & .8 & .8 & .00 & \\
\hline & $1 / 20 / 93$ & $<.2$ & $<.2$ & 0 & & $\mathbf{3}$ & .3 & .00 & & .8 & 1.0 & 1.20 & \\
\hline USGS 89 & $1 / 04 / 89$ & $<.2$ & $<.2$ & 0 & & $<.2$ & $<.2$ & 0 & & $<.2$ & $<.2$ & 0 & \\
\hline & $10 / 16 / 91$ & $<.2$ & $<.2$ & 0 & & $<.2$ & $<.2$ & 0 & & $<.2$ & $<.2$ & 0 & \\
\hline USGS 90 & $1 / 18 / 89$ & $<.2$ & $<.2$ & 0 & & .2 & .2 & .00 & & .4 & .4 & .00 & \\
\hline & $1 / 23 / 90$ & $<.2$ & $<.2$ & 0 & & .2 & .2 & .00 & & .4 & .4 & .00 & \\
\hline & $1 / 16 / 92$ & $<.2$ & $<.2$ & 0 & & .2 & .2 & .00 & & .5 & .4 & 1.20 & \\
\hline & $4 / 20 / 92$ & $<.2$ & $<.2$ & 0 & & .2 & .2 & .00 & & .5 & .5 & .00 & \\
\hline & $10 / 04 / 93$ & $<.2$ & $<.2$ & 0 & & .2 & .2 & .00 & & .4 & .4 & .00 & \\
\hline USGS 117 & $4 / 18 / 91$ & $<.2$ & $<.2$ & 0 & & $<.2$ & $<.2$ & 0 & & $<.2$ & $<.2$ & 0 & \\
\hline USGS 119 & $4 / 03 / 89$ & $<.2$ & $<.2$ & 0 & & $<.2$ & $<.2$ & 0 & & $<.2$ & $<.2$ & 0 & \\
\hline & 4/09/90 & $<.2$ & $<.2$ & 0 & & $<.2$ & $<.2$ & 0 & & $<.2$ & $<.2$ & 0 & \\
\hline USGS 120 & $7 / 19 / 90$ & $<.2$ & $<.2$ & 0 & & .2 & .2 & 0 & & $\mathbf{3}$ & .3 & .00 & \\
\hline
\end{tabular}


Table 52. Comparison of results of replicate pairs of samples from the Idaho National Engineering Laboratory analyzed for total phenols by the National Water Quality Laboratory

[Site identifier: see figures 1-3 for location of sites. QA: quality-assurance replicate sample. Z-value: see section on Statistical Comparisons of Replicate Pairs of Samples for explanation. Abbreviations: $\mu \mathrm{g} / \mathrm{L}$, microgram per liter; $\mathrm{N}$, the analytical results are not in statistical agreement; $U$, statistical agreement of the analytical result is uncertain. Symbol: <, the result was less than the indicated reporting level]

\begin{tabular}{llcccc}
\hline Site identifier & Date sampled & $\begin{array}{c}\text { Total phenols } \\
(\mu \mathrm{g} / \mathrm{L})\end{array}$ & $\begin{array}{c}\text { Total phenols } \\
\mathrm{QA}(\mu \mathrm{g} / \mathrm{L})\end{array}$ & Z-value & Remark \\
\hline NRF-2 & $3 / 21 / 90$ & $<1.0$ & 3.0 & 5.27 & $\mathrm{~N}$ \\
NRF-4 & $2 / 07 / 91$ & 4.0 & 2.0 & 3.73 & $\mathrm{~N}$ \\
NRF-6 & $3 / 10 / 92$ & $<1.0$ & $<1.0$ & 0 & \\
NRF-7 & $1 / 08 / 92$ & 1.0 & $<1.0$ & & $\mathrm{U}$ \\
WSINEL1 & $10 / 07 / 90$ & 2.0 & 1.0 & 3.73 & $\mathrm{~N}$ \\
USGS 12 & $6 / 15 / 90$ & 1.0 & 2.0 & 3.73 & $\mathrm{~N}$ \\
USGS 15 & $8 / 06 / 90$ & 7.0 & 5.0 & 1.94 & \\
USGS 97 & $6 / 07 / 90$ & 3.0 & 3.0 & .00 & \\
& $12 / 07 / 90$ & 2.0 & 1.0 & 3.73 & $\mathrm{~N}$ \\
USGS 98 & $7 / 30 / 90$ & 2.0 & 1.0 & 3.73 & $\mathrm{~N}$ \\
USGS 99 & $10 / 03 / 90$ & $<1.0$ & $<1.0$ & 0 & \\
USGS 102 & $12 / 10 / 90$ & 1.0 & $<1.0$ & & $\mathrm{U}$ \\
\hline
\end{tabular}


Table 53. Results of blank and equipment blank samples from the Idaho National Engineering Laboratory analyzed for sodium, chloride, and chromium by the National Water Quality Laboratory and the Radiological and Environmental Sciences Laboratory

[Site identifier: see section on Quality Assurance/Quality Control Samples, Blank Samples for explanation. Abbreviation: $\mathrm{mg} / \mathrm{L}$, milligram per liter; $\mu \mathrm{g} / \mathrm{L}$, microgram per liter; IBW, inorganic-free blank water, $\mathrm{DW}$, deionized water. Symbols: \#, the analysis was performed by the Radiological and Environmental Sciences Laboratory; <, the result was less than the indicated reporting level; *, the samples were analyzed for the total recoverable constituent, rather than dissolved constituent. Numbers in bold indicate the analytical results exceed known blank water concentration limits for that analysis]

\begin{tabular}{|c|c|c|c|c|c|}
\hline Site identifier & Date sampled & $\begin{array}{c}\text { Sodium } \\
(\mathrm{mg} / \mathrm{L})\end{array}$ & $\begin{array}{c}\text { Chloride } \\
\text { (mg/L) }\end{array}$ & $\begin{array}{c}\text { Chromium } \\
(\mu \mathrm{g} / \mathrm{L})\end{array}$ & $\begin{array}{c}\text { Hexavalent } \\
\text { chromium } \\
(\mu \mathrm{g} / \mathrm{L})\end{array}$ \\
\hline \multicolumn{6}{|c|}{ Blanks } \\
\hline USGS 254 & $2 / 17 / 89$ & & ${ }^{\#} 0 \pm 2$ & ${ }^{\#} 0 \pm 20$ & \\
\hline USGS 288 & $4 / 26 / 89$ & ${ }^{\#} 0 \pm 2$ & ${ }^{\#} 1 \pm 2$ & ${ }^{\#} 10 \pm 20$ & \\
\hline USGS 301 & $6 / 30 / 89$ & & ${ }^{*} 0 \pm 2$ & ${ }^{\#} 0 \pm 20$ & \\
\hline \multirow[t]{2}{*}{ QA-7 } & $10 / 31 / 89$ & ${ }^{\#} 2 \pm 2^{\#}$ & $<.1$ & $\# 10 \pm 20$ & \\
\hline & & $<.1$ & & $<1$ & \\
\hline QAS-1 & $12 / 01 / 89$ & $*<.1$ & $<.1$ & $* 2$ & \\
\hline QA-1 & $9 / 25 / 90$ & .4 & .8 & & \\
\hline QAS-8 & $11 / 02 / 90$ & $* .3$ & $<.1$ & $* 1$ & \\
\hline QAS-23 & $6 / 12 / 92$ & $* .7$ & .8 & $*<1$ & \\
\hline QA-5 & $5 / 07 / 93$ & $<.1$ & .2 & $<1$ & $<1$ \\
\hline \multicolumn{6}{|c|}{ Equipment blanks (IBW or DW) } \\
\hline QA-5 & $7 / 14 / 92$ & .2 & $<.1$ & $<1$ & $<1$ \\
\hline QA-6 & $8 / 13 / 92$ & & .5 & 3 & $<1$ \\
\hline QA-15 & $10 / 22 / 92$ & .2 & .5 & $<1$ & $<1$ \\
\hline QA-10 & $4 / 29 / 93$ & $<.1$ & .2 & $<1$ & $<1$ \\
\hline QA-15 & $4 / 30 / 93$ & & .4 & & \\
\hline QA-1 & $7 / 06 / 93$ & $<.1$ & $<.1$ & $<1$ & $<1$ \\
\hline QA-2 & $7 / 06 / 93$ & .1 & $<.1$ & 1 & $<1$ \\
\hline QA-3 & $7 / 06 / 93$ & $<.1$ & $<.1$ & $<1$ & $<1$ \\
\hline QA-13 & $10 / 13 / 93$ & 15 & .3 & $<1$ & $<1$ \\
\hline QAS-30 & $6 / 15 / 93$ & $*<.1$ & $<.1$ & $*<1$ & \\
\hline \multicolumn{6}{|c|}{ Equipment Blanks (USGS 17 Rinsate) } \\
\hline QA-3 & $04 / 13 / 92$ & & 8.1 & 1 & $<1$ \\
\hline QA-3 & $8 / 07 / 92$ & & 7.5 & 2 & $<1$ \\
\hline QA-8 & $10 / 16 / 92$ & 14 & 6 & 1 & $<1$ \\
\hline QA-4 & $5 / 05 / 93$ & & 5.9 & 1 & 1 \\
\hline \multicolumn{6}{|c|}{ Equipment Blanks (USGS 97 Rinsate) } \\
\hline QA-2 & $7 / 16 / 91$ & & 40 & 6 & $<1$ \\
\hline QA-3 & $10 / 21 / 91$ & 15 & 34 & 6 & $\ldots 2$ \\
\hline QA-5 & $1 / 21 / 92$ & & 29 & & \\
\hline QA-6 & $1 / 21 / 92$ & & 17 & . & \\
\hline
\end{tabular}


Table 54. Results of blank and equipment blank samples from the Idaho National Engineering Laboratory analyzed for sulfate, fluoride, bromide, and total recoverable mercury by the National Water Quality Laboratory

[Site identifier: see section on Quality Assurance/Quality Control Samples, Blank Samples for explanation. Abbreviation: $\mathrm{mg} / \mathrm{L}$, milligram per liter; $\mu \mathrm{g} / \mathrm{L}$, microgram per liter; IBW, inorganic-free blank water. Symbols: <, the result was less than the indicated reporting level. Numbers in bold indicate the analytical results exceed known blank water concentration limits for that analysis]

\begin{tabular}{lccrrr}
\hline Site identifier & Date sampled & $\begin{array}{l}\text { Sulfate } \\
(\mathrm{mg} / \mathrm{L})\end{array}$ & $\begin{array}{c}\text { Fluoride } \\
(\mathrm{mg} / \mathrm{L})\end{array}$ & $\begin{array}{c}\text { Bromide } \\
(\mathrm{mg} / \mathrm{L})\end{array}$ & $\begin{array}{c}\text { Mercury } \\
(\mu \mathrm{g} / \mathrm{L})\end{array}$ \\
\hline & \multicolumn{1}{c}{ Blanks } & & & \\
QAS-1 & $12 / 01 / 89$ & $<1.0$ & $<0.1$ & $<0.01$ & $<0.1$ \\
QAS-8 & $11 / 02 / 90$ & $<1.0$ & $<.1$ & $<.01$ & $<.1$ \\
QAS-23 & $6 / 12 / 92$ & $<.1$ & $<.1$ & .07 & $<.1$ \\
& & Equipment blank (IBW) & & $<.01$ & $<.1$ \\
QAS-30 & $6 / 15 / 93$ & .2 & $<.1$ & $<.01$ \\
\hline
\end{tabular}


Table 55. Results of blank and equipment blank samples from the Idaho National Engineering Laboratory analyzed for nitrite, as nitrogen; nitrite plus nitrate, as nitrogen; ammonia, as nitrogen; and orthophosphate, as phosphorus, by the National Water Quality Laboratory

[Site identifier: see section on Quality Assurance/Quality Control Samples, Blank Samples for explanation. Abbreviation: $\mathrm{mg} / \mathrm{L}$, milligram per liter; IBW, inorganic-free blank water; DW, deionized water. Symbols: <, the result was less than the indicated reporting level. Numbers in bold indicate the analytical results exceed known blank water concentration limits for that analysis]

\begin{tabular}{lccccc}
\hline Site identifier & Date sampled & $\begin{array}{c}\text { Nitrite, as } \\
\text { nitrogen } \\
(\mathrm{mg} / \mathrm{L})\end{array}$ & $\begin{array}{c}\text { Nitrate and } \\
\text { nitrite, as } \\
\text { nitrogen } \\
(\mathrm{mg} / \mathrm{L})\end{array}$ & $\begin{array}{c}\text { Ammonia, as } \\
\text { nitrogen } \\
(\mathrm{mg} / \mathrm{L})\end{array}$ & $\begin{array}{c}\text { Orthophosphate, } \\
\text { as phosphorus } \\
(\mathrm{mg} / \mathrm{L})\end{array}$ \\
\hline QA-7 & \multicolumn{2}{c}{ Blanks } & & \\
QAS-1 & $10 / 31 / 89$ & $<0.01$ & $<0.10$ & $<0.01$ & $<0.01$ \\
QA-1 & $12 / 01 / 89$ & $<.01$ & $<.10$ & .03 & $<.01$ \\
QAS-8 & $9 / 25 / 90$ & $<.01$ & $<.10$ & .10 & $<.01$ \\
QAS-23 & $11 / 02 / 90$ & $<.01$ & $<.10$ & .01 & $<.01$ \\
& $6 / 12 / 92$ & $<.01$ & $<.05$ & $<.01$ & $<.01$ \\
QA-15 & & Equipment blanks $(\mathrm{IBW}$ or DW & & \\
QA-1 & $10 / 22 / 92$ & .02 & .09 & .07 & $<.01$ \\
QA-2 & $7 / 06 / 93$ & $<.01$ & $<.05$ & .01 & $<.01$ \\
QA-3 & $7 / 06 / 93$ & $<.01$ & $<.05$ & .01 & $<.01$ \\
QAS-30 & $7 / 06 / 93$ & $<.01$ & $<.05$ & .02 & $<.01$ \\
\hline
\end{tabular}


Table 56. Results of blank and equipment blank samples from the Idaho National Engineering Laboratory analyzed for total recoverable trace elements: aluminum (Al), arsenic (As), barium (Ba), beryllium (Be), cadmium (Cd), copper (Cu), iron (Fe), lead (Pb), manganese (Mn), nickel (Ni), silver (Ag), and zinc (Zn) by the National Water Quality Laboratory

[Site identifier: see section on Quality Assurance/Quality Control Samples, Blank Samples for explanation. Abbreviations: $\mu \mathrm{g} / \mathrm{L}$, microgram per liter; IBW, inorganic-free blank water. Symbols: <, the result was less than the indicated reporting level. Numbers in bold indicate the analytical results exceed known blank water concentration limits for that analysis]

\begin{tabular}{|c|c|c|c|c|c|c|c|c|c|c|c|c|c|}
\hline $\begin{array}{c}\text { Site } \\
\text { identifier }\end{array}$ & $\begin{array}{c}\text { Date } \\
\text { sampled }\end{array}$ & $\begin{array}{c}\mathrm{Al} \\
(\mu \mathrm{g} / \mathrm{L})\end{array}$ & $\begin{array}{c}\text { As } \\
(\mu \mathrm{g} / \mathrm{L})\end{array}$ & $\begin{array}{c}\mathrm{Ba} \\
(\mu \mathrm{g} / \mathrm{L})\end{array}$ & $\begin{array}{c}\mathrm{Be} \\
(\mu \mathrm{g} / \mathrm{L})\end{array}$ & $\begin{array}{c}\mathrm{Cd} \\
(\mu \mathrm{g} / \mathrm{L})\end{array}$ & $\begin{array}{c}\mathrm{Cu} \\
(\mu \mathrm{g} / \mathrm{L})\end{array}$ & $\begin{array}{c}\mathrm{Fe} \\
(\mu \mathrm{g} / \mathrm{L})\end{array}$ & $\begin{array}{c}\mathrm{Pb} \\
(\mu \mathrm{g} / \mathrm{L})\end{array}$ & $\begin{array}{c}\mathrm{Mn} \\
(\mu \mathrm{g} / \mathrm{L})\end{array}$ & $\begin{array}{c}\mathrm{Ni} \\
(\mu \mathrm{g} / \mathrm{L})\end{array}$ & $\begin{array}{c}\mathrm{Ag} \\
(\mu \mathrm{g} / \mathrm{L})\end{array}$ & $\underset{(\mu \mathrm{g} / \mathrm{L})}{\mathrm{Zn}}$ \\
\hline \multicolumn{14}{|c|}{ Blanks } \\
\hline QAS-1 & $12 / 01 / 89$ & 20 & $<1$ & $<100$ & $<10$ & $<1$ & 15 & 80 & 3 & $<10$ & & $<1$ & 10 \\
\hline QAS-8 & $11 / 02 / 90$ & & $<1$ & $<100$ & & $<1$ & 1 & $<10$ & $<1$ & $<10$ & 1 & $<1$ & $<10$ \\
\hline QAS-23 & $6 / 12 / 92$ & & & & & & & $<10$ & $<1$ & & $<1$ & $<1$ & \\
\hline \multicolumn{14}{|c|}{ Equinment blank (IBW) } \\
\hline
\end{tabular}


Table 57. Results of blank and equipment blank samples from the Idaho National Engineering Laboratory analyzed for gross alpha and gross beta radioactivity by the National Water Quality Laboratory

[Site identifier: see section on Quality Assurance/Quality Control Samples, Blank Samples for explanation. Abbreviations: $\mathrm{pCi} / \mathrm{L}$, picocurie per liter; $\mu \mathrm{g} / \mathrm{L}$, microgram per liter; IBW, inorganic-free blank water; Sr-90/Y-90, strontium-90/yttrium-90. Numbers in bold indicate the analytical results exceed known blank water concentration limits for that analysis]

\begin{tabular}{|c|c|c|c|c|c|}
\hline Site identifier & Date sampled & $\begin{array}{l}\text { Gross alpha, } \\
\text { dissolved, as } \\
\text { thorium-230 } \\
\text { (pCi/L) }\end{array}$ & $\begin{array}{l}\text { Gross alpha, } \\
\text { suspended, as } \\
\text { thorium-230 } \\
\text { (pCi/L) }\end{array}$ & $\begin{array}{c}\text { Gross alpha, } \\
\text { dissolved, as } \\
\text { natural uranium } \\
(\mathrm{mg} / \mathrm{L})\end{array}$ & $\begin{array}{c}\text { Gross alpha, } \\
\text { suspended, as } \\
\text { natural uranium } \\
(\mathrm{mg} / \mathrm{L})\end{array}$ \\
\hline \multicolumn{6}{|c|}{ Blanks } \\
\hline QAS-1 & $12 / 01 / 89$ & $-0.327 \pm 0.183$ & $0.639 \pm 0.285$ & $0.643 \pm 0.286$ & $-0.334 \pm 0.186$ \\
\hline QAS-8 & $11 / 02 / 90$ & $-.126 \pm 0.160$ & $.057 \pm 0.203$ & $.084 \pm 0.299$ & $-.236 \pm 0.288$ \\
\hline QAS-23 & $6 / 12 / 92$ & $.157 \pm 0.222$ & $.010 \pm 0.179$ & $.231 \pm 0.328$ & $.019 \pm 0.333$ \\
\hline \multicolumn{6}{|c|}{ Equipment blank (IBW) } \\
\hline QAS-30 & $6 / 15 / 93$ & $-.011 \pm 0.007$ & & $-.018 \pm 0.120$ & \\
\hline Site identifier & Date sampled & $\begin{array}{l}\text { Gross beta, } \\
\text { dissolved, as } \\
\text { cesium-137 } \\
(\mathrm{pC} / \mathrm{L})\end{array}$ & $\begin{array}{l}\text { Gross beta, } \\
\text { suspended, as } \\
\text { cesium- } 137 \\
\text { (pCi/L) }\end{array}$ & $\begin{array}{l}\text { Gross beta, } \\
\text { dissolved, as } \\
\mathrm{Sr}-90 / \mathrm{Y}-90 \\
\text { (pCi/L) }\end{array}$ & $\begin{array}{l}\text { Gross beta, } \\
\text { suspended, as } \\
\text { Sr-90/Y-90 } \\
\text { (pCi/L) }\end{array}$ \\
\hline \multicolumn{6}{|c|}{ Blanks } \\
\hline QAS-1 & $12 / 01 / 89$ & $0.779 \pm 0.343$ & $-1.89 \pm 0.46$ & $0.721 \pm 0.317$ & $-1.91 \pm 0.46$ \\
\hline QAS-8 & $11 / 02 / 90$ & $.260 \pm 0.374$ & $-.049 \pm 0.488$ & $.249 \pm 0.356$ & $-.048 \pm 0.475$ \\
\hline QAS-23 & $6 / 12 / 92$ & $.196 \pm 0.344$ & $.186 \pm 0.491$ & $.188 \pm 0.329$ & $.18 .1 \pm 0.477$ \\
\hline \multicolumn{6}{|c|}{ Equipment blank (IBW) } \\
\hline QAS-30 & $6 / 15 / 93$ & $-.072 \pm 0.306$ & & $-.070 \pm 0.299$ & \\
\hline
\end{tabular}


Table 58. Results of blank samples from the Idaho National Engineering Laboratory analyzed for radium-226 and radium-228 by the National Water Quality Laboratory

[Site identifier: see section on Quality Assurance/Quality Control Samples, Blank Samples for explanation.

Abbreviations: $\mathrm{pCi} / \mathrm{L}$, picocurie per liter. Numbers in bold indicate the analytical results exceed known blank water concentration limits for that analysis]

\begin{tabular}{|c|c|c|c|}
\hline Site identifier & Date sampled & $\begin{array}{c}\text { Radium-226 } \\
(\mathrm{pCi} / \mathrm{L})\end{array}$ & $\begin{array}{l}\text { Radium-228 } \\
\quad(\mathrm{pCi} / \mathrm{L})\end{array}$ \\
\hline QAS-1 & $12 / 01 / 89$ & $0.490 \pm 0.150$ & $2.52+0.56$ \\
\hline QAS-8 & $11 / 02 / 90$ & $.075 \pm 0.016$ & $.472 \pm 0.390$ \\
\hline
\end{tabular}


Table 59. Results of blank and equipment blank samples from the Idaho National Engineering Laboratory analyzed for gamma radiation, strontium-90, and tritium by the National Water Quality Laboratory and the Radiological and Environmental Sciences Laboratory

[Site identifier: see section on Quality Assurance/Quality Control Samples, Blank Samples for explanation. Abbreviations: $\mathrm{pCi} / \mathrm{L}$, picocurie per liter; IBW, inorganic-free blank water; DW, deionized water. Symbol: \#\#, the analysis was performed by the National Water Quality Laboratory. Numbers in bold indicate the analytical results exceed known blank water concentration limits for that analysis]

\begin{tabular}{|c|c|c|c|c|}
\hline Site identifier & Date sampled & $\begin{array}{l}\text { Gamma radiation } \\
\qquad(\mathrm{pCi} / \mathrm{L})\end{array}$ & $\begin{array}{l}\text { Strontium-90 } \\
(\mathrm{pCi} / \mathrm{L})\end{array}$ & $\begin{array}{l}\text { Tritium } \\
(\mathrm{pCi} / \mathrm{L})\end{array}$ \\
\hline \multicolumn{5}{|c|}{ Blanks } \\
\hline USGS 288 & $4 / 26 / 89$ & & $-4.5 \pm 1.6$ & $17,000 \pm 500$ \\
\hline USGS 301 & $6 / 30 / 89$ & & $-1.5 \pm 1.4$ & $2700 \pm 200$ \\
\hline QA-7 & $10 / 31 / 89$ & & & $-50 \pm 150$ \\
\hline QAS-1 & $12 / 01 / 89$ & & & $\# 185.6 \pm 25.6$ \\
\hline QA-1 & $9 / 25 / 90$ & $-20 \pm 40$ & $2 \pm 2$ & $170 \pm 180$ \\
\hline QA-5 & $5 / 07 / 93$ & $-20 \pm 20$ & $.3 \pm 1.6$ & $-200 \pm 160$ \\
\hline \multicolumn{5}{|c|}{ Equipment blanks (IBW or DW) } \\
\hline QA-5 & $7 / 14 / 92$ & $40 \pm 30$ & $-.8 \pm 1.6$ & $200 \pm 200$ \\
\hline QA-6 & $8 / 13 / 92$ & $-20 \pm 20$ & $3 \pm 2$ & $120 \pm 180$ \\
\hline QA-15 & $10 / 22 / 92$ & $30 \pm 30$ & $.4 \pm 1.5$ & $0 \pm 200$ \\
\hline QA-10 & $4 / 29 / 93$ & $-15 \pm 20$ & $.2 \pm 1.5$ & $-60 \pm 170$ \\
\hline QA-15 & $4 / 30 / 93$ & $-14 \pm 17$ & $-.7 \pm 1.6$ & $-260 \pm 160$ \\
\hline QA-1 & $7 / 06 / 93$ & & $2.3 \pm 1.6$ & $230 \pm 170$ \\
\hline QA-2 & $7 / 06 / 93$ & & $3 \pm 2$ & $80 \pm 160$ \\
\hline QA-3 & $7 / 06 / 93$ & & $-.7 \pm 1.5$ & $-10 \pm 160$ \\
\hline QA-13 & $10 / 15 / 93$ & $-15 \pm 27$ & $2 \pm 2$ & $0 \pm 200$ \\
\hline \multicolumn{5}{|c|}{ Equipment blanks (USGS 17 Rinsate) } \\
\hline QA-3 & $4 / 13 / 92$ & $7.0 \pm 15$ & $1.0 \pm 1.5$ & $-110 \pm 180$ \\
\hline QA-3 & $8 / 07 / 92$ & & $-1.3 \pm 1.6$ & $110 \pm 180$ \\
\hline QA-8 & $10 / 16 / 92$ & & $0 \pm 2$ & $100 \pm 200$ \\
\hline QA-4 & $5 / 05 / 93$ & $0 \pm 20$ & $.6 \pm 1.6$ & $-150 \pm 160$ \\
\hline \multicolumn{5}{|c|}{ Equipment blanks (USGS 97 Rinsate) } \\
\hline QA-2 & 9/16/91 & $-30+30$ & & $150 \pm 170$ \\
\hline QA-3 & $10 / 21 / 91$ & & $0 \pm 2$ & $0 \pm 200$ \\
\hline QA-5 & $1 / 21 / 92$ & & $1.1 \pm 1.5$ & $-140 \pm 180$ \\
\hline QA-6 & $1 / 21 / 92$ & & $.9 \pm 1.5$ & $-160 \pm 180$ \\
\hline
\end{tabular}


Table 60. Results of blank samples from the Idaho National Engineering Laboratory analyzed for americium-241, plutonium-238, and plutonium-239/240 by the Radiological and Environmental Sciences Laboratory

[Site identifier: see section on Quality Assurance/Quality Control Samples, Blank Samples for explanation. Abbreviations: $\mathrm{pCi} / \mathrm{L}$, picocurie per liter]

\begin{tabular}{ccccc}
\hline Site identifier & Date sampled & $\begin{array}{c}\text { Americium-241 } \\
(\mathrm{pCi} / \mathrm{L})\end{array}$ & $\begin{array}{c}\text { Plutonium-238 } \\
(\mathrm{pCi} / \mathrm{L})\end{array}$ & $\begin{array}{c}\text { Plutonium-239/240 } \\
(\mathrm{pCi} / \mathrm{L})\end{array}$ \\
\hline QA-1 & $9 / 25 / 90$ & $0.015 \pm 0.034$ & $0.03 \pm 0.02$ & $-0.017 \pm 0.014$ \\
QA-5 & $5 / 07 / 93$ & $.012 \pm 0.020$ & $.017 \pm 0.014$ & $.04 \pm 0.02$ \\
\hline
\end{tabular}


Table 61. Results of blank and equipment blank samples from the Idaho National Engineering Laboratory analyzed for organic constituents which exceeded the reporting level by the National Water Quality Laboratory

[Site identifier: see section on Quality Assurance/Quality Control Samples, Blank Samples for explanation. Abbreviations: $\mathrm{mg} / \mathrm{L}$, milligram per liter; $\mu \mathrm{g} / \mathrm{L}$, microgram per liter; $\mathrm{DW}$, deionized water]

\begin{tabular}{|c|c|c|c|c|c|c|c|}
\hline $\begin{array}{c}\text { Site } \\
\text { identifier }\end{array}$ & Date sampled & $\begin{array}{c}\text { Total organic } \\
\text { carbon } \\
(\mathrm{mg} / \mathrm{L})\end{array}$ & $\begin{array}{l}\text { Methylene } \\
\text { chloride } \\
(\mu \mathrm{g} / \mathrm{L})\end{array}$ & $\begin{array}{c}\text { bis(2-ethylhexyl) } \\
\text { phthalate } \\
(\mu \mathrm{g} / \mathrm{L})\end{array}$ & $\begin{array}{c}\text { Hexane } \\
(\mu \mathrm{g} / \mathrm{L})\end{array}$ & $\begin{array}{c}\text { Toluene } \\
(\mu \mathrm{g} / \mathrm{L})\end{array}$ & $\begin{array}{c}\text { Total } \\
\text { phenols } \\
(\mu \mathrm{g} / \mathrm{L})\end{array}$ \\
\hline \multicolumn{8}{|c|}{ Blanks } \\
\hline QAS-1 & $12 / 01 / 89$ & & & 28 & & & 4 \\
\hline QAS-8 & $11 / 02 / 90$ & 0.5 & & & & & 2 \\
\hline QA-16 & $11 / 02 / 92$ & & 1.9 & & & & \\
\hline QA-5 & $5 / 07 / 93$ & & .2 & & & 0.3 & \\
\hline \multicolumn{8}{|c|}{ Equipment blank (DW) } \\
\hline QAB-1 & $2 / 21 / 92$ & & 9.0 & & Present & & \\
\hline
\end{tabular}


Table 62. Upper-tail areas for a normal curve

[The statistical table was compiled by J.W. Stegeman (R.L. Ott, 1993, p. A-3). The level of significance (or $p$-value) is the area and must be multiplied by two for two-tailed tests]

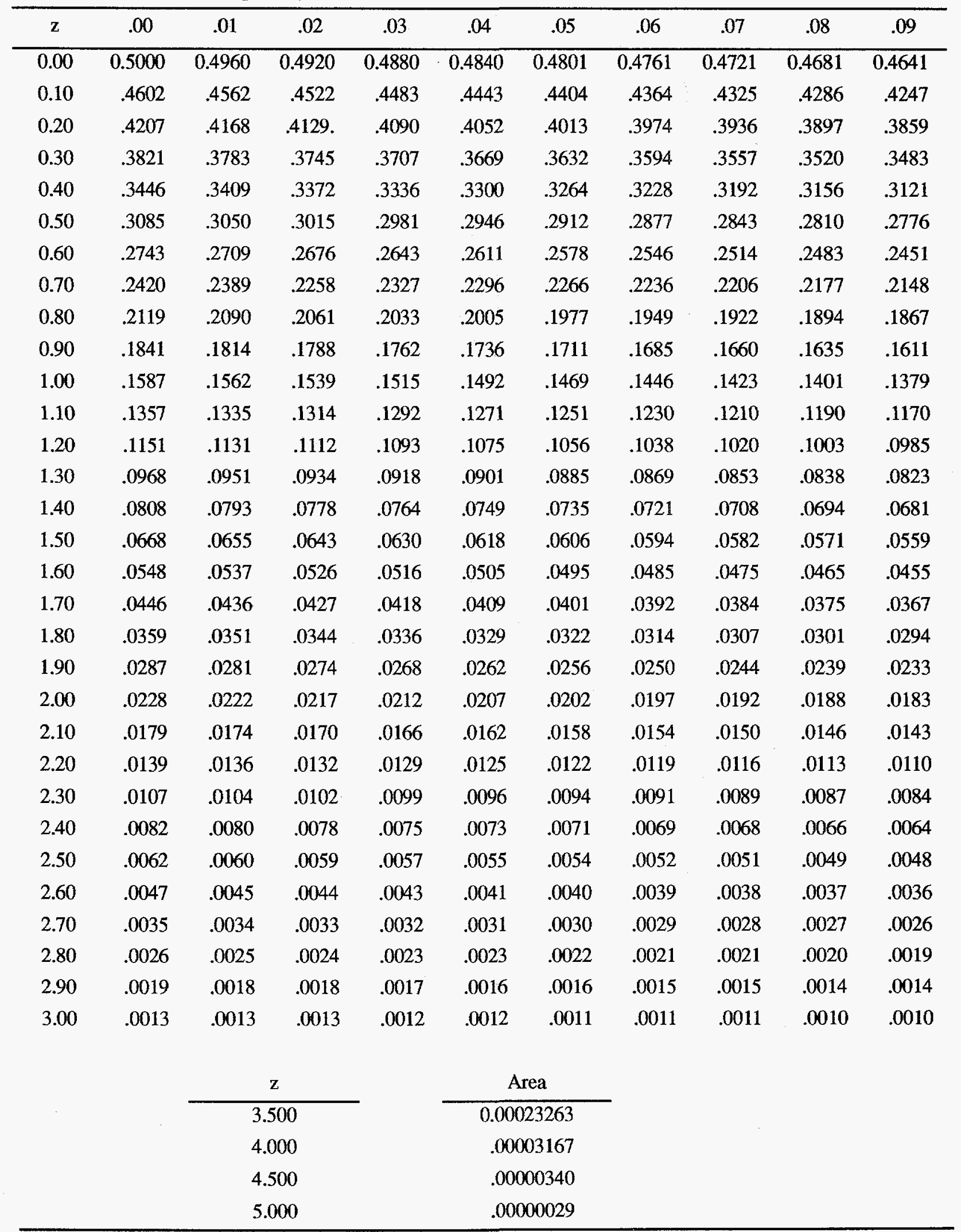


Table 63. Site identifiers and sampling dates for replicate sample pairs collected for analysis of specific types of organic constituents

[Site identifier: see figures 1-3 for location of sites. The analyses of volatile organic constituents included 25 additional compounds for four replicate sample pairs in 1992 and two more additional compounds for two replicate sample pairs in 1993. The analyses of semivolatile organic constituents included three additional compounds for two replicate sample pairs in 1992]

\begin{tabular}{|c|c|c|c|}
\hline Site identifier & Date sampled & Site identifier & Date sampled \\
\hline \multicolumn{2}{|c|}{ Volatile organic compounds ( 36$)$} & \multicolumn{2}{|c|}{$\begin{array}{l}\text { Semivolatile organic compounds (54) } \\
\text { chlorophenoxy-acid herbicides, and organochlorine } \\
\text { insecticides with gross PCB's and gross PCN's }\end{array}$} \\
\hline RWMC Prod. & $10 / 30 / 90$ & NRF-2 & $3 / 21 / 90$ \\
\hline USGS 12 & $6 / 15 / 90$ & NRF-4 & 2/07/91 \\
\hline USGS 44 & $10 / 26 / 90$ & NRF-6 & $3 / 10 / 92$ \\
\hline USGS 87 & $4 / 21 / 92$ & NRF-7 & $1 / 08 / 92$ \\
\hline \multirow[t]{3}{*}{ USGS 88} & $7 / 12 / 89$ & WSINEL1 & $12 / 07 / 90$ \\
\hline & $7 / 16 / 91$ & USGS 12 & $6 / 15 / 90$ \\
\hline & $1 / 20 / 93$ & USGS 15 & $8 / 06 / 90$ \\
\hline \multirow[t]{2}{*}{ USGS 89} & $1 / 04 / 89$ & USGS 97 & $6 / 07 / 90$ \\
\hline & $10 / 16 / 91$ & & $12 / 07 / 90$ \\
\hline \multirow[t]{5}{*}{ USGS 90} & $1 / 18 / 89$ & USGS 98 & $7 / 30 / 90$ \\
\hline & $1 / 23 / 90$ & USGS 99 & $10 / 03 / 90$ \\
\hline & $1 / 16 / 92$ & USGS 102 & $1: 12 / 10 / 90$ \\
\hline & $4 / 20 / 92$ & & \\
\hline & $10 / 04 / 93$ & & \\
\hline USGS 117 & $4 / 18 / 91$ & & \\
\hline \multirow[t]{2}{*}{ USGS 119} & $4 / 03 / 89$ & & \\
\hline & $4 / 09 / 90$ & & \\
\hline USGS 120 & $7 / 19 / 90$ & & \\
\hline \multicolumn{2}{|c|}{ Volatile organic compounds (25) added in 1992} & \multicolumn{2}{|c|}{ Semivolatile organic compounds (3) added in 1992} \\
\hline USGS 87 & $4 / 21 / 92$ & NRF-6 & $3 / 10 / 92$ \\
\hline USGS 88 & $1 / 20 / 93$ & NRF-7 & $1 / 08 / 92$ \\
\hline \multirow[t]{2}{*}{ USGS 90} & $4 / 20 / 92$ & & \\
\hline & $10 / 04 / 93$ & & \\
\hline \multicolumn{2}{|c|}{ Volatile organic compounds (2) added in 1993} & \multicolumn{2}{|c|}{$\frac{\text { Triazine herbicides, organophosphate and carbamate }}{\text { insecticides. and Aroclors }}$} \\
\hline USGS 88 & $1 / 20 / 93$ & USGS 12 & $6 / 15 / 90$ \\
\hline USGS 90 & $10 / 04 / 93$ & & \\
\hline
\end{tabular}


Table 64. Organic compounds and respective reporting levels for the specific types of organic constituents in table 63

[Reporting levels are microgram per liter (Pritt and Jones, 1989; A. C. Watterson and A.T. Kashuba, USGS, written commun., 1993)]

\begin{tabular}{|c|c|c|c|c|c|}
\hline \multicolumn{2}{|c|}{ Compound and reporting level } & \multicolumn{2}{|c|}{ Compound and reporting level } & \multicolumn{2}{|c|}{ Compound and reporting level } \\
\hline \multicolumn{6}{|c|}{ Volatile organic compounds ( 36$)$} \\
\hline Benzene & 0.2 & 1,4-Dichlorobenzene & 0.2 & Methyl bromide & 0.2 \\
\hline Bromoform & .2 & Dichlorodiffuoromethane & .2 & Methylene chloride & .2 \\
\hline Carbon tetrachloride & .2 & 1,2-Dibromoethane & .2 & Styrene & .2 \\
\hline Chlorobenzene & .2 & 1,1-Dichloroethane & .2 & 1,1,2,2-Tetrachloroethane & .2 \\
\hline Chloroethane & .2 & 1,2-Dichloroethane & .2 & Tetrachloroethylene & .2 \\
\hline Chloromethane & .2 & 1,1-Dichloroethylene & .2 & Toluene & .2 \\
\hline 2-Chloroethyl vinyl ether & $.2^{1}$ & 1,2-trans-Dichloroethylene & .2 & 1,1,1-Trichloroethane & .2 \\
\hline Chloroform & .2 & 1,2-Dichloropropane & .2 & 1,1,2-Trichloroethane & .2 \\
\hline Dibromochloromethane & .2 & Cis-1,3-Dichloropropene & .2 & Trichloroethylene & .2 \\
\hline Dichlorobromomethane & .2 & Trans-1,3-Dichloropropene & .2 & Trichlorofluoromethane & .2 \\
\hline 1,2-Dichlorobenzene & .2 & 1,3-Dichloropropene ${ }^{2}$ & .2 & Vinyl chloride & .2 \\
\hline 1,3-Dichlorobenzene & .2 & Ethylbenzene & .2 & Xylenes, mixed & .2 \\
\hline \multicolumn{6}{|c|}{ Volatile organic compounds (25) added in 1992} \\
\hline Acrolein & 20 & Dibromomethane & .2 & Naphthalene & .2 \\
\hline Acrylonitrile & 20 & Cis-1,2-dichloroethylene & .2 & N-propylbenzene & .2 \\
\hline Bromobénzene & .2 & 1,3-Dichloropropane & .2 & 1,1,1,2-Tetrachloroethane & .2 \\
\hline N-Butylbenzene & .2 & 2,2-Dichloropropane & .2 & 1,2,3-Trichlorobenzene & .2 \\
\hline Sec-butylbenzene & .2 & 1,1-Dichloropropene & .2 & 1,2,4-Trichlorobenzene & .2 \\
\hline Tert-butylbenzene & .2 & Hexachlorobutadiene & .2 & 1,2,3-Trichloropropane & .2 \\
\hline 1,2-Chlorotoluene & .2 & Isopropylbenzene & .2 & 1,2,4-Trimethylbenzene & .2 \\
\hline 1,4-Chlorotoluene & .2 & P-isopropyltoluene & .2 & 1,3,5-Trimethylbenzene & .2 \\
\hline Dibromochloropropane & 1 & & & & \\
\hline \multicolumn{6}{|c|}{ Volatile organic compounds (2) added in 1993} \\
\hline Bromochloromethane & .2 & Methyltertbutylether & 1 & & \\
\hline \multicolumn{6}{|c|}{$\underline{\text { Semivolatile Organic Compounds (54) }}$} \\
\hline Acenaphthene & 5.0 & 1,2,5,6-Dibenzanthracene & 10.0 & Hexachlorocyclopentadiene & 5.0 \\
\hline Acenaphthylene & 5.0 & 1,2-Dichlorobenzene & 5.0 & Hexachloroethane & 5.0 \\
\hline Anthracene & 5.0 & 1,3-Dichlorobenzene & 5.0 & Indeno $(1,2,3-c d)$ pyrene & 10.0 \\
\hline Benzo (a) anthracene & 10.0 & 1,4-Dichlorobenzene & 5.0 & Isophorone & 5.0 \\
\hline Benzo (b) fluoranthene & 10.0 & 2,4-Dichlorophenol & 5.0 & 2-Methyl-4,6-dinitrophenol & 30.0 \\
\hline Benzo (k) fluoranthene & 10.0 & Diethyl phthalate & 5.0 & Naphthalene & 5.0 \\
\hline Benzo $(g, h, i)$ perylene & 10.0 & Dimethyl phthalate & 5.0 & Nitrobenzene & 5.0 \\
\hline
\end{tabular}


Table 64. Organic compounds and respective reporting levels for the specific types of organic constituents in table 63-continued

\begin{tabular}{|c|c|c|c|c|c|}
\hline \multicolumn{2}{|c|}{ Compound and reporting level } & \multicolumn{2}{|c|}{ Compound and reporting level } & \multicolumn{2}{|c|}{ Compound and reporting level } \\
\hline Benzo (a) pyrene & 10.0 & 2,4-Dimethylphenol & 5.0 & 2-Nitrophenol & 5.0 \\
\hline 4-Bromophenyl phenyl ether & 5.0 & Di-n-butyl phthalate & 5.0 & 4-Nitrophenol & 30.0 \\
\hline Butyl benzyl phthalate & 5.0 & 2,4-Dinitrophenol & 20 & n-Nitrosodimethylamine & 5.0 \\
\hline bis (2-Chloroethoxy) methane & 5.0 & 2,4-Dinitrotoluene & 5.0 & n-Nitrosodi-n-propylamine & 5.0 \\
\hline bis (2-Chloroethyl) ether & 5.0 & 2,6-Dinitrotoluene & 5.0 & n-Nitrosodiphenylamine & 5.0 \\
\hline bis (2-Chloroisopropyl) ether & 5.0 & Di-n-octyl phthalate & 10.0 & Pentachlorophenol & 30.0 \\
\hline 4-Chloro-3-methylphenol & 30.0 & Bis (2-ethylhexyl)phthalate & 5.0 & Phenanthrene & 5.0 \\
\hline 2-Chloronaphthalene & 5.0 & Fluoranthene & 5.0 & Phenol & 5.0 \\
\hline 2-Chlorophenol & 5.0 & Fluorene & 5.0 & Pyrene & 5.0 \\
\hline 4-Chlorophenyl phenyl ether & 5.0 & Hexachlorobenzene & 5.0 & 1,2,4-Trichlorobenzene & 5.0 \\
\hline Chrysene & 10.0 & Hexachlorobutadiene & 5.0 & 2,4,6-Trichlorophenol & 20.0 \\
\hline \multicolumn{6}{|c|}{ Semivolatile organic compounds (3) added in 1992} \\
\hline Benzidine & 40 & 3,3'-Dichlorobenzidine & 20 & 1,2-Diphenylhydrazine & \\
\hline \multicolumn{6}{|c|}{ Chlorophenoxy-acid herbicides } \\
\hline 2,4-D & .01 & Silvex & .01 & $2,4,5-\mathrm{T}$ & .01 \\
\hline 2,4-DP & .01 & & & & \\
\hline \multicolumn{6}{|c|}{ Organochlorine insecticides } \\
\hline Aldrin & .01 & Dieldrin & .01 & Lindane & .01 \\
\hline Chlordane & .1 & Endosulfan & .01 & Methoxychlor & .01 \\
\hline DDD & .01 & Endrin & .01 & Mirex & .01 \\
\hline DDE & .01 & Heptachlor & .01 & Perthane & .1 \\
\hline DDT & .01 & Heptachlor epoxide & .01 & Toxaphene & 1.0 \\
\hline \multicolumn{6}{|c|}{ Gross polvchlorinated compounds } \\
\hline $\begin{array}{l}\text { Gross polychlorinated } \\
\text { biphenyls (PCB) }\end{array}$ & .1 & $\begin{array}{l}\text { Gross polychlorinated } \\
\text { naphthalenes }(\mathrm{PCN})\end{array}$ & .1 & & \\
\hline \multicolumn{6}{|c|}{ Triazine herbicides } \\
\hline Alachlor & .1 & Metolachor & .1 & Propazine & .1 \\
\hline Ametryn & .1 & Metribuzin & .1 & Simazine & .1 \\
\hline Atrazine & .1 & Prometon & .1 & Simetryn & .1 \\
\hline Cyanazine & .1 & Prometryn & .1 & Trifluralin & .1 \\
\hline \multicolumn{6}{|c|}{ Organophosphate insecticides } \\
\hline Diazinon & .01 & Methyl parathion & .01 & \multirow{2}{*}{$\begin{array}{l}\text { Phosphorotrithioate, } \\
\text { S,S,S-Tributyl-(DEF) }\end{array}$} & .01 \\
\hline Disulfoton (Di-syston) & .01 & Methyl trithion & .01 & & \\
\hline Ethion & .01 & Parathion & .01 & Trithion & .01 \\
\hline Malathion & .01 & Phorate & .01 & & \\
\hline
\end{tabular}


Table 64. Organic compounds and respective reporting levels for the specific types of organic.constituents in table 63-continued

\begin{tabular}{lrlrlr}
\hline \multicolumn{1}{c}{ Compound and reporting level } & \multicolumn{2}{c}{ Compound and reporting level } & \multicolumn{2}{c}{ Compound and reporting level } \\
\hline & & \multicolumn{2}{c}{ Carbamate insecticides } \\
Aldicarb & 0.5 & Carbofuran & 0.5 & 1-Naphthol & 0.5 \\
Aldicarb sufone & .5 & 3-Hydroxycarbofuran & .5 & Oxamyl & .5 \\
Aldicarb sulfoxide & .5 & Methomyl & .5 & Propham & .5 \\
Carbaryl (Sevin) & .5 & & & & .1 \\
& & & Aroclors (polychlorinated biphenvls) & & .1 \\
Aroclor 1016 & .1 & Aroclor 1242 & .1 & Aroclor 1254 \\
Aroclor 1221 & .1 & Aroclor 1248 & .1 & Aroclor 1260 & .1 \\
Aroclor 1232 & .1 & & & & \\
\hline
\end{tabular}

${ }^{1}$ In 1993 , the reporting level of 2-chloroethyl vinyl ether increased from 0.2 microgram per liter to 1 microgram per liter.

${ }^{2}$ In 1992, analyses of volatile organic compounds did not include 1,3-dichloropropene. 